Prepared in cooperation with the California State Water Resources Control Board A product of the California Groundwater Ambient Monitoring and Assessment (GAMA) Program

\title{
Groundwater-Quality Data in Seven GAMA Study Units: Results from Initial Sampling, 2004-2005, and Resampling, 2007-2008, of Wells: California GAMA Program Priority Basin Project
}

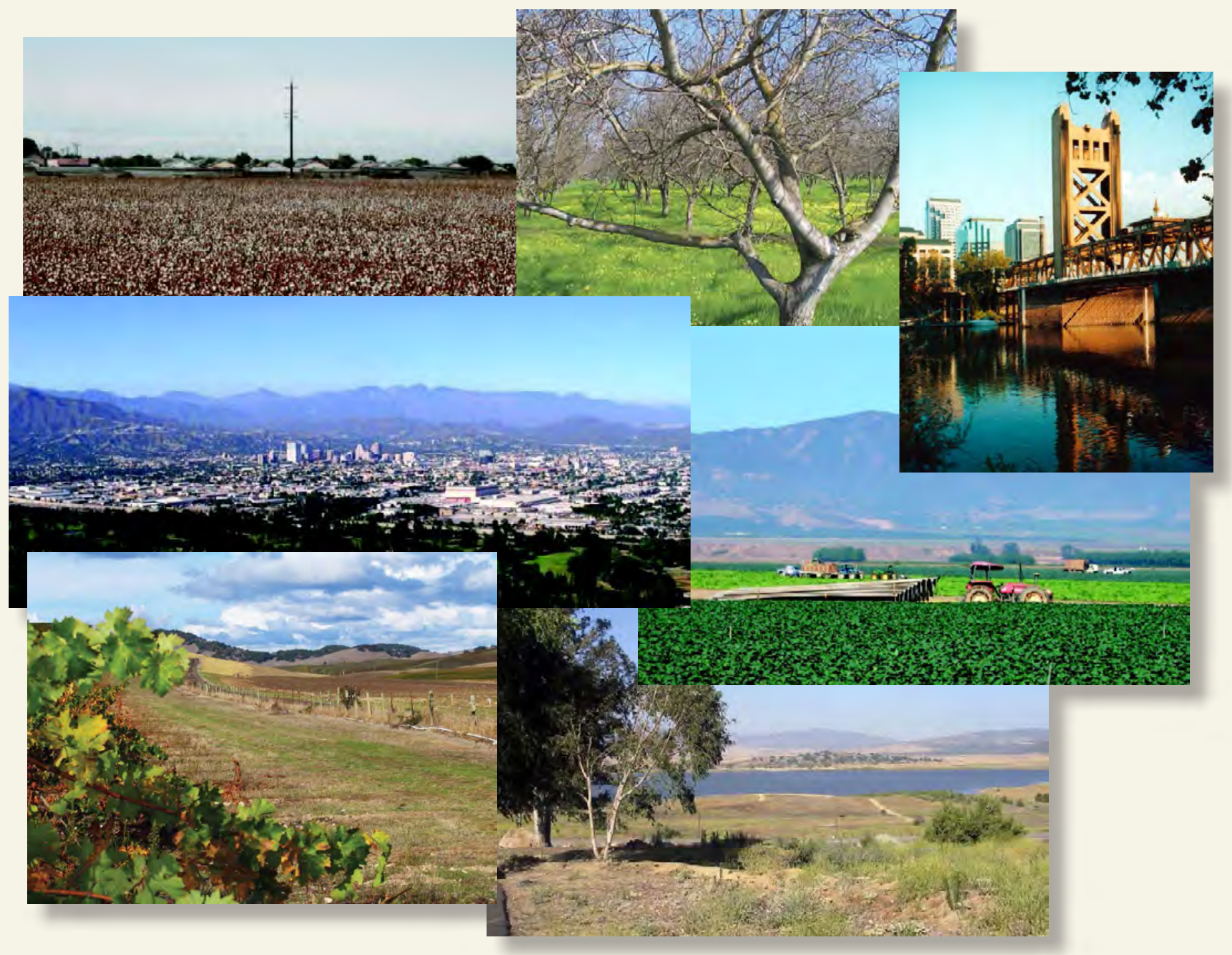

Data Series 795

U.S. Department of the Interior

U.S. Geological Survey 


\section{Cover photographs}

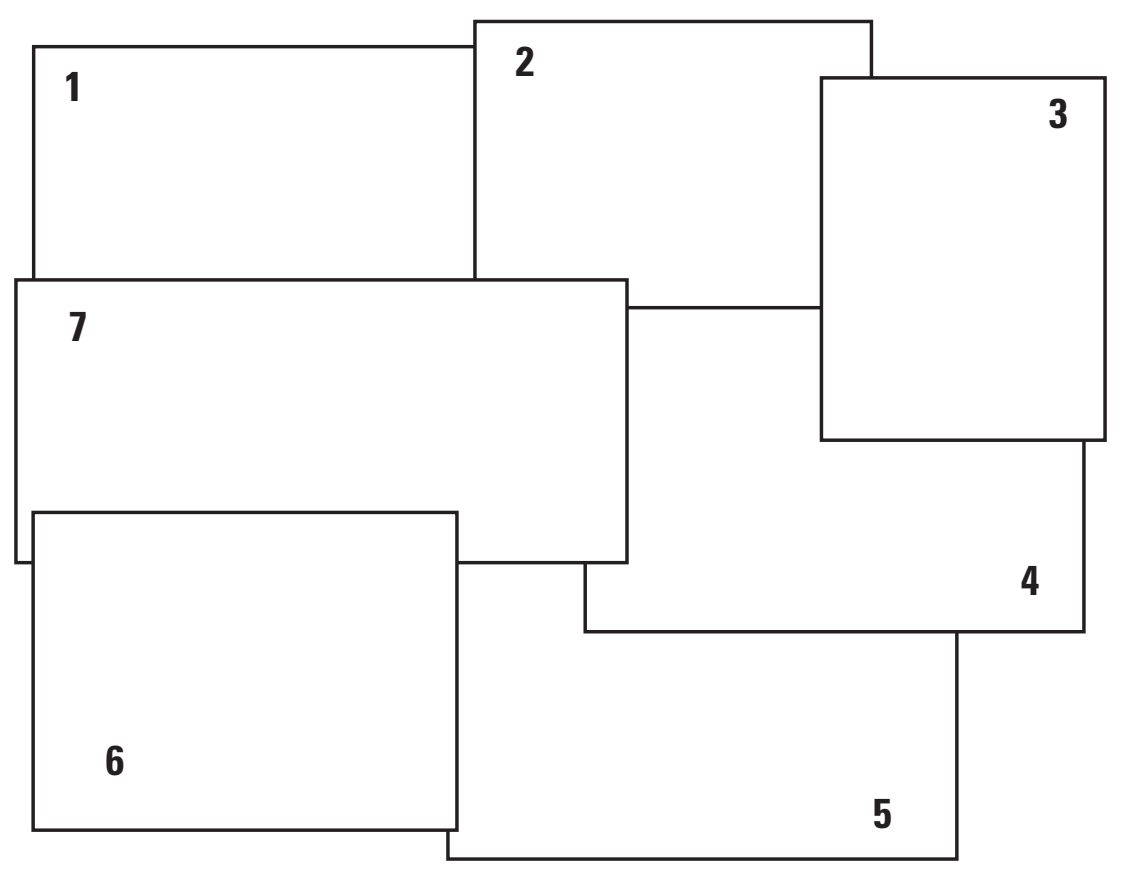

Cover. 1. Cotton fields near Fresno, California. (Photograph taken by Justin Kulongoski, U.S. Geological Survey.)

2. Almond orchard near near Fresno, California. (Photograph taken by Cathy Munday, U.S. Geological Survey.)

3. Tower Bridge over the Sacramento River, Sacramento, California. (Photograph taken by Cathy Munday, U.S. Geological Survey.)

4. Salinas Valley agriculture in Monterey County, California. (Photograph taken by Andrea Altmann, U.S. Geological Survey.)

5. Lake Henshaw in San Diego County, California. (Photograph taken by Barbara Dawson, U.S. Geological Survey.)

6. Vineyards in the North San Francisco Bay area, California. (Photograph taken by George Bennett, V, U.S. Geological Survey.)

7. Looking northeast from Griffith Park. Downtown Glendale is in the middle ground, and the San Gabriel Mountains are in the background. (Photograph taken July 12, 2006, by Will Bebeck.) 


\section{Groundwater-Quality Data in Seven GAMA Study Units: Results from Initial Sampling, 2004-2005, and Resampling, 2007-2008, of Wells: California GAMA Program Priority Basin Project}

By Robert Kent, Kenneth Belitz, and Miranda S. Fram

A product of the California Groundwater Ambient Monitoring and Assessment (GAMA) Program

Prepared in cooperation with the California State Water Resources Control Board

Data Series 795 


\title{
U.S. Department of the Interior SALLY JEWELL, Secretary
}

\section{U.S. Geological Survey Suzette M. Kimball, Acting Director}

\author{
U.S. Geological Survey, Reston, Virginia: 2014
}

For more information on the USGS - the Federal source for science about the Earth, its natural and living resources, natural hazards, and the environment, visit http://www.usgs.gov or call 1-888-ASK-USGS.

For an overview of USGS information products, including maps, imagery, and publications, visit http://www.usgs.gov/ pubprod

To order this and other USGS information products, visit http://store.usgs.gov

Any use of trade, firm, or product names is for descriptive purposes only and does not imply endorsement by the U.S. Government.

Although this information product, for the most part, is in the public domain, it also may contain copyrighted materials as noted in the text. Permission to reproduce copyrighted items must be secured from the copyright owner.

Suggested citation:

Kent, Robert, Belitz, Kenneth, and Fram, M.S., 2014, Groundwater-quality data in seven GAMA study units: Results from initial sampling, 2004-2005, and resampling, 2007-2008, of wells: California GAMA Program Priority Basin Project: U.S. Geological Survey Data Series 795, 170 p., http://dx.doi.org/10.3133/ds795.

ISSN 2327-638X (online) 


\section{Contents}

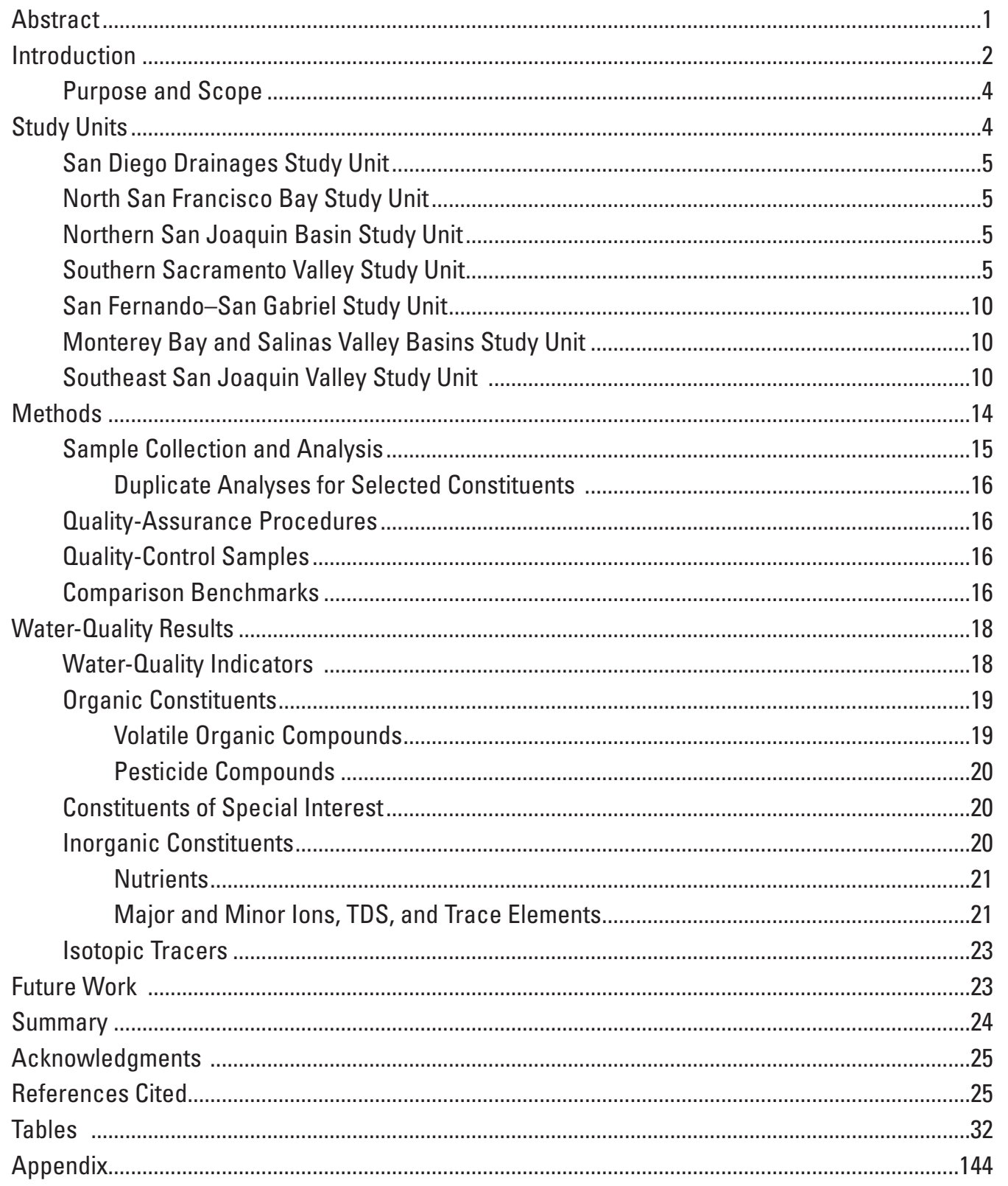




\section{Figures}

1. Map showing the hydrogeologic provinces of California and the locations of the GAMA study units featured in this report...

2. Map showing the San Diego Drainages GAMA study unit with locations of study areas, status wells, and trend wells

3. Map showing the North San Francisco Bay GAMA study unit with locations of study areas, status wells, and trend wells..

4. Map showing the Northern San Joaquin Basin GAMA study unit with locations of study areas, status wells, and trend wells....

5. Map showing the Southern Sacramento Valley GAMA study unit with locations of study areas, status wells, and trend wells.....

6. Map showing the San Fernando-San Gabriel GAMA study unit with locations of study areas, status wells, and trend wells.

7. Map showing the Monterey Bay and Salinas Valley Basins GAMA study unit with locations of study areas, status wells, and trend wells ...

8. Map showing the Southeast San Joaquin Valley GAMA study unit with locations of study areas, status wells, and trend wells.

\section{Tables}

1. Identification, sampling, and construction information for trend wells sampled for seven GAMA study units

2. Number of water-quality indicators and chemical constituents measured in samples collected at trend wells for the GAMA study units featured in this report

3A. Volatile organic compounds, primary uses or sources, comparative benchmarks, and reporting information for the USGS National Water Quality Laboratory Schedule 2020

3B. 1,2-Dibromo-3-chloropropane (DBCP) and 1,2-dibromoethane (EDB), primary uses or sources, comparative benchmarks, and reporting information for the USGS National Water Quality Laboratory Schedule 1306.

3C. Pesticides and pesticide degradates, primary uses or sources, comparative benchmarks, and reporting information for the USGS National Water Quality Laboratory Schedule 2003, and the expanded versions Schedule 2032 and Schedule 2033

3D. Polar pesticides, pesticide degradates, and caffeine, primary uses or sources, comparative benchmarks, and reporting information for the USGS National Water Quality Laboratory Schedule 2060

3E. Nutrients, comparative benchmarks, and reporting information for the USGS National Water Quality Laboratory Schedule 2755.

3F. Major and minor ions, total dissolved solids, trace elements, comparative benchmarks, and reporting information for the USGS National Water Quality Laboratory Schedule 1948

3G. Arsenic and iron species, comparative benchmarks, and reporting information for the USGS Trace Metal Laboratory, Boulder, Colorado 


\section{Tables-Continued}

3H. Constituents of special interest, primary uses or sources, comparative benchmarks, and reporting information for the Montgomery Watson Harza Laboratory and Weck Laboratories, Inc.

31. Isotopic and radioactive constituents, comparative benchmarks, and reporting information for laboratories

4. Water-quality indicators in samples collected from trend wells for seven GAMA study units.

5. Volatile organic compounds (VOCs) in samples collected from trend wells for seven GAMA study units

6A. Pesticides and pesticide degradates (Schedules, 2003, 2032, and 2033) in samples collected from trend wells for seven GAMA study units...

6B. Polar pesticides (Schedule 2060) in samples collected from trend wells for seven GAMA study units .104

7. Constituents of special interest in samples collected from trend wells sampled

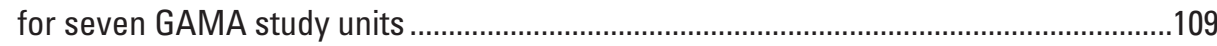

8. Nutrients in samples collected from trend wells for seven GAMA study units.............114

9. Major and minor ions and dissolved solids in samples collected from trend wells for seven GAMA study units.

10. Trace elements in groundwater samples collected from trend wells for seven GAMA study units

11. Arsenic and iron oxidation-reduction species in samples collected from trend wells for seven GAMA study units.

12. Isotopic tracers in samples collected from trend wells for seven GAMA study units 


\title{
Conversion Factors, Datums, and Abbreviations and Acronyms
}

\author{
Conversion Factors
}

Inch/foot/mile to SI

\begin{tabular}{lcl}
\hline & Multiply & \multicolumn{1}{c}{ By obtain } \\
\hline inch (in.) & Length & \\
inch (in.) & 2.54 & centimeter $(\mathrm{cm})$ \\
foot (ft) & 25.4 & millimeter $(\mathrm{mm})$ \\
mile (mi) & 0.3048 & meter $(\mathrm{m})$ \\
\hline & 1.609 & kilometer $(\mathrm{km})$ \\
\hline square foot $\left(\mathrm{ft}^{2}\right)$ & Area & \\
square mile $\left(\mathrm{mi}^{2}\right)$ & 0.09290 & square meter $\left(\mathrm{m}^{2}\right)$ \\
\hline & 2.590 & square kilometer $\left(\mathrm{km}^{2}\right)$ \\
\hline picocurie per liter $(\mathrm{pCi} / \mathrm{L})$ & Radioactivity & becquerel per liter $(\mathrm{Bq} / \mathrm{L})$ \\
\hline
\end{tabular}

Temperature in degrees Celsius $\left({ }^{\circ} \mathrm{C}\right)$ may be converted to degrees Fahrenheit $\left({ }^{\circ} \mathrm{F}\right)$ as follows: ${ }^{\circ} \mathrm{F}=\left(1.8 x^{\circ} \mathrm{C}\right)+32$.

Temperature in degrees Fahrenheit $\left({ }^{\circ} \mathrm{F}\right)$ may be converted to degrees Celsius $\left({ }^{\circ} \mathrm{C}\right)$ as follows: ${ }^{\circ} \mathrm{C}=\left({ }^{\circ} \mathrm{F}-32\right) / 1.8$.

Specific conductance is given in microsiemens per centimeter at 25 degrees Celsius $(\mu \mathrm{S} / \mathrm{cm}$ at $\left.25^{\circ} \mathrm{C}\right)$.

Concentrations of chemical constituents in water are given either in milligrams per liter (mg/L) or micrograms per liter ( $\mu \mathrm{g} / \mathrm{L})$. One milligram per liter is equivalent to 1 part per million (ppm); 1 microgram per liter is equivalent to 1 part per billion (ppb); 1 nanogram per liter $(\mathrm{ng} / \mathrm{L})$ is equivalent to 1 part per trillion (ppt). Isotopic constituents are given in delta notation $\left(\delta^{i} E\right)$ as the ratio of a heavier isotope of an element $\left({ }^{i} E\right)$ relative to the more common lighter isotope of that element, relative to a standard reference material, expressed as per mil; 1 per mil is equivalent to 1 part per thousand.

Vertical coordinate information is referenced to the North American Vertical Datum of 1988 (NAVD 88).

Horizontal coordinate information is referenced to the North American Datum of 1983 (NAD 83). 


\title{
Abbreviations and Acronyms
}

\author{
AL-US U.S. Environmental Protection Agency action level \\ APE Alternate Place Entry program (USGS) \\ CAS Chemical Abstract Service (American Chemical Society Registry Number ${ }^{\circledR}$ ) \\ CSU combined standard uncertainties \\ E estimated or having a high degree of uncertainty \\ GAMA Groundwater Ambient Monitoring and Assessment Program \\ GPS global positioning system \\ HAL-US U.S. Environmental Protection Agency lifetime health advisory level \\ LRL laboratory reporting level \\ LSD land-surface datum \\ LT-MDL long-term method detection level \\ MCL-CA California Department of Public Health maximum contaminant level \\ MCL-US U.S. Environmental Protection Agency maximum contaminant level \\ MDL method detection limit \\ MRL minimum reporting level \\ na not available \\ NAVD 88 North American Vertical Datum of 1988 \\ nc not collected \\ NFM National Field Manual (USGS) \\ NL-CA California Department of Public Health notification level \\ nv no value in category \\ NWIS National Water Information System (USGS) \\ PBP Priority Basin Project \\ PCFF Personal Computer Field Form program designed for USGS sampling \\ QA quality assurance \\ QC quality control \\ $\mathrm{RL} \quad$ reporting level \\ RSD relative standard deviation \\ RSD5-US U.S. Environmental Protection Agency risk-specific dose at a risk factor of $10^{-5}$ \\ SMCL-CA California Department of Public Health secondary maximum contaminant level \\ SMCL-US U.S. Environmental Protection Agency secondary maximum contaminant level \\ SRL study reporting level \\ $\mathrm{ssL}_{\mathrm{c}} \quad$ sample-specific critical level
}




\section{Well Identifier Prefixes}

COS Prefix for well in the Cosumnes Basin study area of the Northern San Joaquin Basin study unit

ESJ Prefix for well in the Eastern San Joaquin Basin study area of the Northern San Joaquin Basin study unit

KING Prefix for well in the Kings study area of the Southeast San Joaquin Valley study unit

KWH Prefix for well in the Kaweah study area of the Southeast San Joaquin Valley study unit

MSMB Prefix for well in the Monterey Bay study area of the Monterey Bay and Salinas Valley study unit

MSPR Prefix for well in the Paso Robles study area of the Monterey Bay and Salinas Valley study unit

MSSC Prefix for well in the Santa Cruz study area of the Monterey Bay and Salinas Valley study unit

MSSV Prefix for well in the Salinas Valley study area of the Monterey Bay and Salinas Valley study unit

NAM Prefix for well in the North American study area of the Southern Sacramento Valley study unit

NSFVOL Prefix for well in the Volcanic Highlands study area of the North San Francisco Bay study unit

NSFVP Prefix for well in the Valley and Plains study area of the North San Francisco Bay study unit

NSFWG Prefix for well in the Wilson Grove Formation Highlands study area of the North San Francisco Bay study unit

NSFWGFP Prefix for well on a flow path in the Wilson Grove Formation Highlands study area of the North San Francisco Bay study unit

NSJ-OPC Prefix for well in the Uplands Basin study area of the Northern San Joaquin Basin study unit

SAM Prefix for well in the South American study area of the Southern Sacramento Valley study unit

SDALLV Prefix for well in the Alluvial Basins study area of the San Diego Drainages study unit

SDHDRK Prefix for well in the Hard Rock study area of the San Diego Drainages study unit

SDTEM Prefix for well in the Temecula Valley study area of the San Diego Drainages study unit

SDTEMFP Prefix for well on a flow path in the Temecula Valley study area of the San Diego Drainages study unit

SDWARN Prefix for well in the Warner Valley study area of the San Diego Drainages study unit 


\section{Well Identifier Prefixes-Continued}

SOL Prefix for well in the Solano study area of the Southern Sacramento Valley study unit

SSV-OPC Prefix for well in the Uplands study area of the Southern Sacramento Valley study unit

SUI Prefix for well in the Suisun-Fairfield study area of the Southern Sacramento Valley study unit

TLR Prefix for well in the Tulare Lake study area of the Southeast San Joaquin Valley study unit

TRCY Prefix for well in the Tracy Basin study area of the Northern San Joaquin Basin study unit

TULE Prefix for well in the Tule study area of the Southeast San Joaquin Valley study unit

ULASF Prefix for well in the San Fernando study area of the San Fernando-San Gabriel study unit

ULASG Prefix for well in the San Gabriel study area of the San Fernando-San Gabriel study unit

YOL Prefix for well in the Yolo study area of the Southern Sacramento Valley study unit

\section{Organizations}

$\begin{array}{ll}\text { BQS } & \text { Branch of Quality Systems (USGS) } \\ \text { CDPH } & \text { California Department of Public Health } \\ \text { CDPR } & \text { California Department of Pesticide Regulation } \\ \text { CDWR } & \text { California Department of Water Resources } \\ \text { LLNL } & \text { Lawrence Livermore National Laboratory, Livermore, California } \\ \text { MWH } & \text { Montgomery Watson Harza Laboratory } \\ \text { NAWQA } & \text { National Water-Quality Assessment Program (USGS) } \\ \text { NELAP } & \text { National Environmental Laboratory Accreditation Program } \\ \text { NFOA } & \text { National Field Quality Assurance Program (USGS) } \\ \text { NRP } & \text { National Research Program (USGS) } \\ \text { NWOL } & \text { National Water Quality Laboratory, Denver, Colorado (USGS) } \\ \text { SWRCB } & \text { State Water Resources Control Board (California) } \\ \text { TML } & \text { Trace Metal Laboratory, Boulder, Colorado (USGS) } \\ \text { USEPA } & \text { U.S. Environmental Protection Agency } \\ \text { USGS } & \text { U.S. Geological Survey } \\ \text { Weck } & \text { Weck Laboratories, Inc., City of Industry, California }\end{array}$




\section{Selected chemical names}

$\begin{array}{ll}\mathrm{CaCO}_{3} & \text { calcium carbonate } \\ \mathrm{CO}_{3}^{2-} & \text { carbonate } \\ \mathrm{DBCP} & \text { 1,2-dibromo-3-chloropropane } \\ \mathrm{EDB} & \text { 1,2-dibromoethane } \\ \mathrm{HCl} & \text { hydrochloric acid } \\ \mathrm{HCO}_{3}^{-} & \text {bicarbonate } \\ \text { MTBE } & \text { methyl tert-butyl ether } \\ \mathrm{NDMA} & \text { N-nitrosodimethylamine } \\ \mathrm{PCE} & \text { perchloroethene, tetrachloroethene } \\ \text { 1,2,3-TCP } & 1,2,3 \text {-trichloropropane } \\ \text { TCE } & \text { trichloroethene } \\ \text { TDS } & \text { total dissolved solids } \\ \text { THM } & \text { trihalomethane } \\ \text { VOC } & \text { volatile organic compound }\end{array}$

\section{Units of Measure}

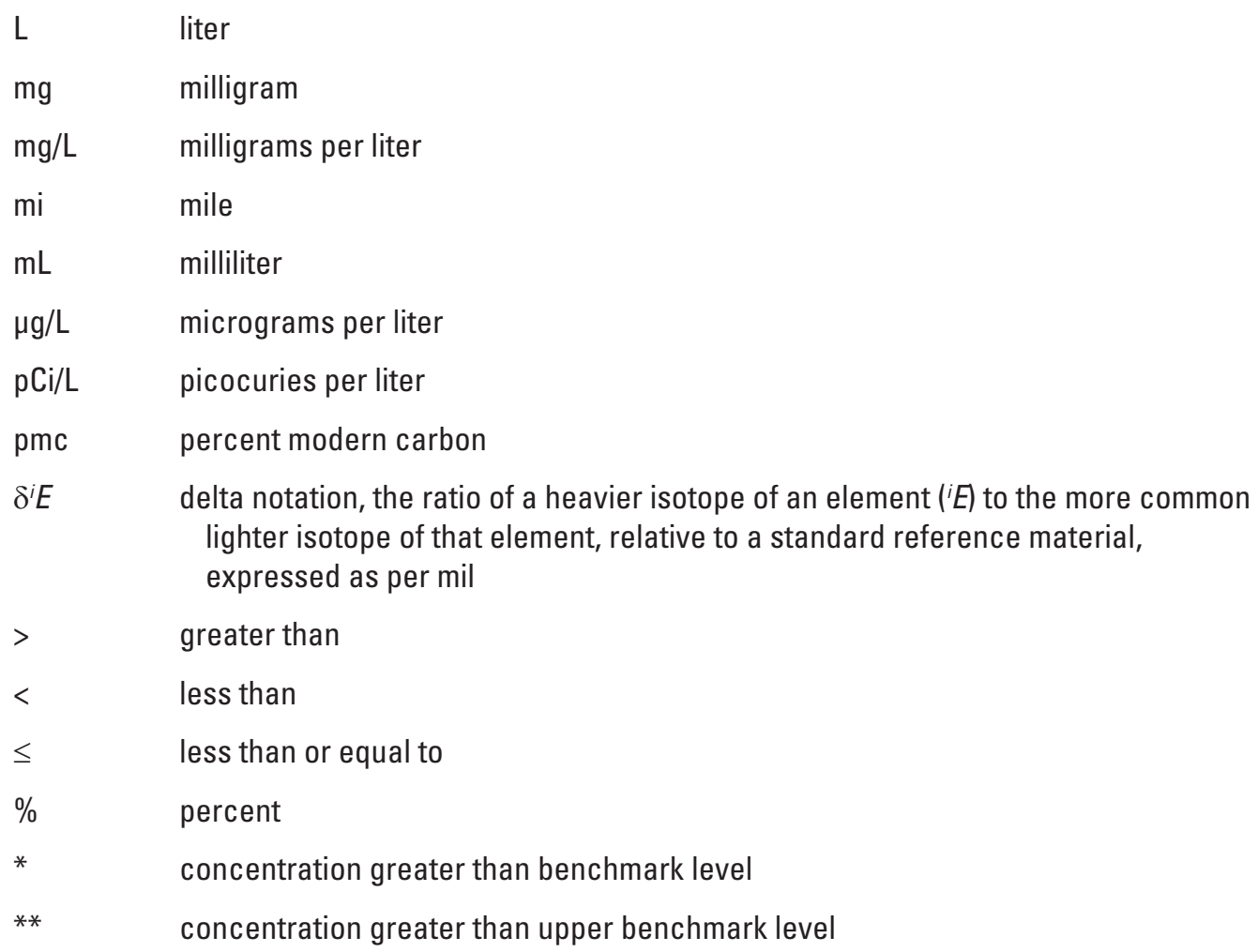




\title{
Groundwater-Quality Data in Seven GAMA Study Units: Results from Initial Sampling, 2004-2005, and Resampling, 2007-2008, of Wells: California GAMA Program Priority Basin Project
}

\author{
By Robert Kent, Kenneth Belitz, and Miranda S. Fram
}

\section{Abstract}

The Priority Basin Project (PBP) of the Groundwater Ambient Monitoring and Assessment (GAMA) Program was developed in response to the Groundwater Quality Monitoring Act of 2001 and is being conducted by the U.S. Geological Survey (USGS) in cooperation with the California State Water Resources Control Board (SWRCB). The GAMA-PBP began sampling, primarily public supply wells in May 2004. By the end of February 2006, seven (of what would eventually be 35) study units had been sampled over a wide area of the State. Selected wells in these first seven study units were resampled for water quality from August 2007 to November 2008 as part of an assessment of temporal trends in water quality by the GAMA-PBP.

The initial sampling was designed to provide a spatially unbiased assessment of the quality of raw groundwater used for public water supplies within the seven study units. In the 7 study units, 462 wells were selected by using a spatially distributed, randomized grid-based method to provide statistical representation of the study area. Wells selected this way are referred to as grid wells or status wells. Approximately 3 years after the initial sampling, 55 of these previously sampled status wells (approximately 10 percent in each study unit) were randomly selected for resampling. The seven resampled study units, the total number of status wells sampled for each study unit, and the number of these wells resampled for trends are as follows, in chronological order of sampling: San Diego Drainages (53 status wells, 7 trend wells), North San Francisco Bay $(84,10)$, Northern San Joaquin Basin (51, 5), Southern Sacramento Valley $(67,7)$, San Fernando-San Gabriel $(35,6)$, Monterey Bay and Salinas Valley Basins $(91,11)$, and Southeast San Joaquin Valley $(83,9)$.

The groundwater samples were analyzed for a large number of synthetic organic constituents (volatile organic compounds [VOCs], pesticides, and pesticide degradates), constituents of special interest (perchlorate, $\mathrm{N}$-nitrosodimethylamine [NDMA], and 1,2,3-trichloropropane $[1,2,3-\mathrm{TCP}])$, and naturally-occurring inorganic constituents (nutrients, major and minor ions, and trace elements). Naturally-occurring isotopes (tritium, carbon-14, and stable isotopes of hydrogen and oxygen in water) also were measured to help identify processes affecting groundwater quality and the sources and ages of the sampled groundwater. Nearly 300 constituents and water-quality indicators were investigated.

Quality-control samples (blanks, replicates, and samples for matrix spikes) were collected at 24 percent of the 55 status wells resampled for trends, and the results for these samples were used to evaluate the quality of the data for the groundwater samples. Field blanks rarely contained detectable concentrations of any constituent, suggesting that contamination was not a noticeable source of bias in the data for the groundwater samples. Differences between replicate samples were mostly within acceptable ranges, indicating acceptably low variability in analytical results. Matrix-spike recoveries were within the acceptable range ( 70 to 130 percent) for 75 percent of the compounds for which matrix spikes were collected.

This study did not attempt to evaluate the quality of water delivered to consumers. After withdrawal, groundwater typically is treated, disinfected, and blended with other waters to maintain acceptable water quality. The benchmarks used in this report apply to treated water that is served to the consumer, not to untreated groundwater. To provide some context for the results, however, concentrations of constituents measured in these groundwater samples were compared with benchmarks established by the U.S. Environmental Protection Agency (USEPA) and California Department of Public Health (CDPH). Comparisons between data collected for this study and benchmarks for drinking water are for illustrative purposes only and are not indicative of compliance or noncompliance with those benchmarks. 
Most constituents that were detected in groundwater samples from the trend wells were found at concentrations less than drinking-water benchmarks. Four VOCstrichloroethene, tetrachloroethene, 1,2-dibromo-3chloropropane, and methyl tert-butyl ether-were detected in one or more wells at concentrations greater than their health-based benchmarks, and six VOCs were detected in at least 10 percent of the samples during initial sampling or resampling of the trend wells. No pesticides were detected at concentrations near or greater than their healthbased benchmarks. Three pesticide constituents - atrazine, deethylatrazine, and simazine-were detected in more than 10 percent of the trend-well samples during both sampling periods. Perchlorate, a constituent of special interest, was detected more frequently, and at greater concentrations during resampling than during initial sampling, but this may be due to a change in analytical method between the sampling periods, rather than to a change in groundwater quality. Another constituent of special interest, 1,2,3-TCP, was also detected more frequently during resampling than during initial sampling, but this pattern also may not reflect a change in groundwater quality. Samples from several of the wells where 1,2,3-TCP was detected by low-concentration-level analysis during resampling were not analyzed for 1,2,3-TCP using a low-level method during initial sampling. Most detections of nutrients and trace elements in samples from trend wells were less than health-based benchmarks during both sampling periods. Exceptions include nitrate, arsenic, boron, and vanadium, all detected at concentrations greater than their health-based benchmarks in at least one well during both sampling periods, and molybdenum, detected at concentrations greater than its health-based benchmark during resampling only. The isotopic ratios of oxygen and hydrogen in water and tritium and carbon-14 activities generally changed little between sampling periods, suggesting that the predominant sources and ages of groundwater in most trend wells were consistent between the sampling periods.

\section{Introduction}

About one-half of the water used for public and domestic drinking-water supply in California is groundwater (Kenny and others, 2009). To assess the quality of ambient groundwater in aquifers used for public drinking-water supply and to establish a baseline groundwater-quality monitoring program, the California State Water Resources Control Board (SWRCB) in cooperation with the U.S. Geological Survey (USGS) and Lawrence Livermore National Laboratory (LLNL) implemented the Groundwater Ambient Monitoring and Assessment (GAMA) Program in 2000 (California State Water Resources Control Board, 2012, website at http:// www.waterboards.ca.gov/gama/). The main goals of the GAMA Program are to improve groundwater monitoring and to increase the availability of groundwater-quality data to the public. The GAMA Program currently consists of four projects: (1) the GAMA Priority Basin Project (PBP), conducted by the USGS (U.S. Geological Survey, 2011, California Water Science Center website at http://ca.water. usgs.gov/gama/); (2) the GAMA Domestic Well Project, conducted by the SWRCB; (3) GAMA Special Studies Project, conducted by LLNL; and (4) GeoTracker GAMA, conducted by the SWRCB. The GAMA-PBP primarily focuses on the deep part of the groundwater resource, which is typically used for public drinking-water supply. The GAMA Domestic Well Project generally focuses on the shallow aquifer systems, which may be particularly at risk as a result of surficial contamination. The GAMA Special Studies Project focuses on using research methods to help explain the source, fate, transport, and occurrence of chemicals that can affect groundwater quality. GeoTracker GAMA is an online interface serving data from the GAMA Program and other efforts to the public (http://geotracker.waterboards.ca.gov/).

The GAMA Program was initiated by the SWRCB in 2000 and later expanded by the Groundwater Quality Monitoring Act of 2001 (State of California, 2001a, b; Sections 10780-10782.3 of the California Water Code, Assembly Bill 599). The GAMA-PBP assesses groundwater quality in key groundwater basins that account for more than 90 percent of all groundwater used for public supply in the State. For the GAMA-PBP, the USGS, in collaboration with the SWRCB, developed the monitoring plan to assess groundwater basins through direct and other statistically reliable sampling approaches (Belitz and others, 2003; California State Water Resources Control Board, 2003). Additional partners in the GAMA-PBP include the California Department of Public Health (CDPH), California Department of Water Resources (CDWR), California Department of Pesticide Regulation (CDPR), local water agencies, and well owners (Kulongoski and Belitz, 2004). Participation in the GAMA-PBP is entirely voluntary.

The GAMA-PBP is unique in California because it includes many chemical analyses that are not otherwise available in the statewide water-quality monitoring datasets. Groundwater samples collected for the GAMA-PBP are typically analyzed for approximately 300 chemical constituents using analytical methods with lower detection limits than required by the CDPH for regulatory monitoring of water from drinking-water wells. These analyses will be useful for providing an early indication of changes in groundwater quality. In addition, the GAMA-PBP analyzes samples for a suite of constituents more extensive than required by $\mathrm{CDPH}$ and for a suite of chemical and isotopic tracers for understanding hydrologic and geochemical processes. This understanding of groundwater composition is useful for identifying the natural and human factors affecting water quality. Understanding the occurrence and distribution of chemical constituents of significance to water quality is important for the long-term management and protection of groundwater resources. 
The range of hydrologic, geologic, and climatic conditions in California were considered in this statewide assessment of groundwater quality. Belitz and others (2003) partitioned the State into 10 hydrogeologic provinces, each with distinctive hydrologic, geologic, and climatic characteristics: Cascades and Modoc Plateau, Klamath Mountains, Northern Coast Ranges, Central Valley, Sierra Nevada, Basin and Range, Southern Coast Ranges, Transverse
Ranges and selected Peninsular Ranges, Desert, and San Diego Drainages (fig. 1). These 10 hydrogeologic provinces include groundwater basins and subbasins designated by the CDWR (California Department of Water Resources, 2003). Groundwater basins and subbasins generally consist of relatively permeable, unconsolidated deposits of alluvial origin. Eighty percent of California's approximately 16,000 active and standby drinking-water wells listed in the

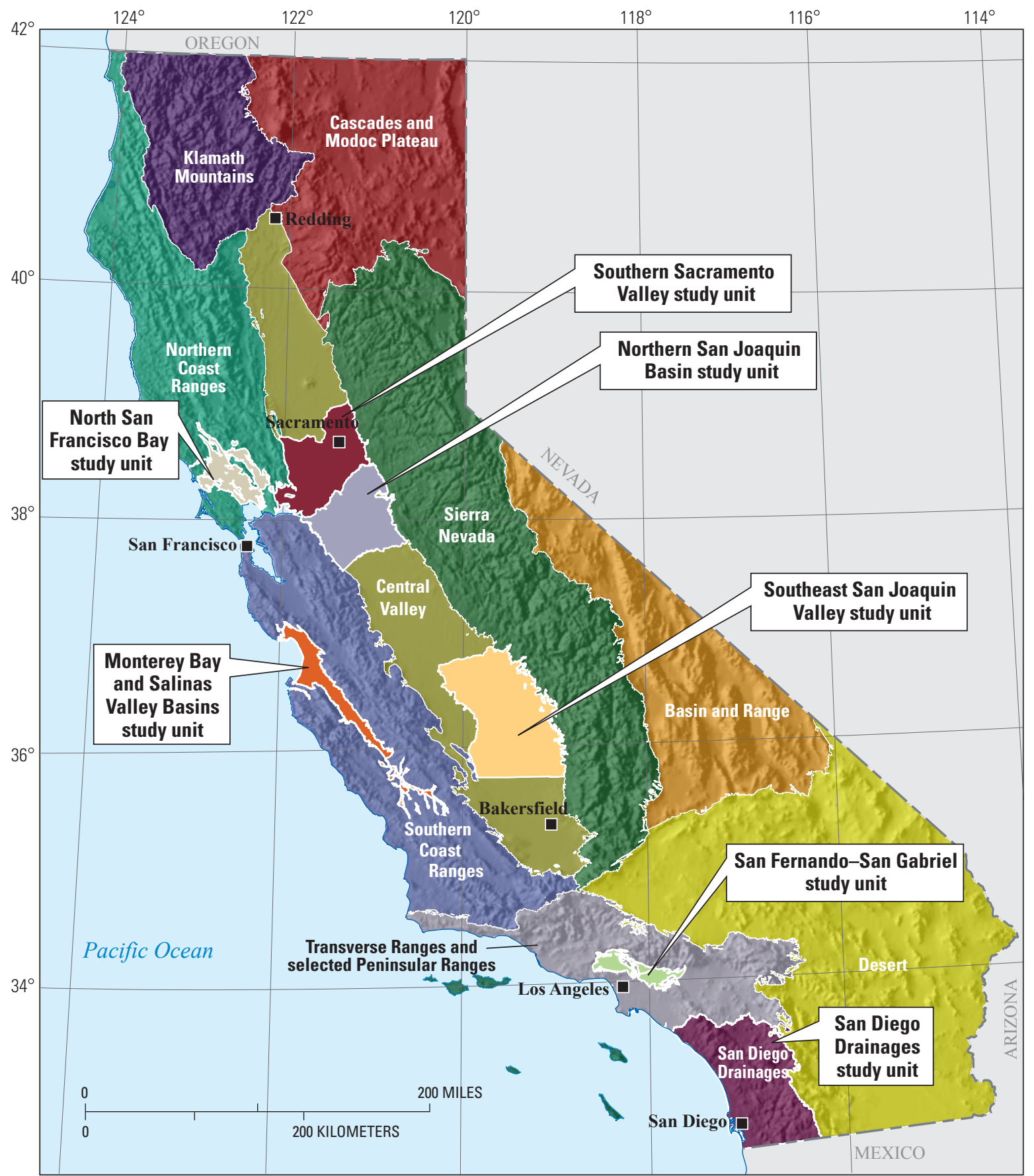

Shaded relief derived from U.S. Geological Survey National Elevation Dataset, 2006,

Provinces from Belitz and others, 2003 Albers Equal Area Conic Projection

Figure 1. Hydrogeologic provinces of California and the locations of the Groundwater Ambient Monitoring and Assessment (GAMA) study units featured in this report. 
statewide database maintained by the CDPH (hereinafter referred to as CDPH wells) are located in groundwater basins and subbasins within the 10 hydrogeologic provinces. Groundwater basins and subbasins were prioritized for sampling on the basis of the number of CDPH wells in the basin, with secondary consideration given to municipal groundwater use, agricultural pumping, the number of formerly leaking underground fuel tanks, and the number of square-mile sections with registered pesticide applications (Belitz and others, 2003). Of the 472 basins and subbasins designated by the CDWR, 116 basins and subbasins, defined as the priority basins, contained 90 percent of the $\mathrm{CDPH}$ wells in basins. The remaining 356 basins and subbasins were defined as low-use basins. The 116 priority basins and subbasins, selected low-use basins, and selected areas outside of the defined groundwater basins were selected and grouped into 35 GAMA study units, representing approximately 95 percent of the CDPH wells in California.

The data collected in each study unit is used for three types of water-quality assessments: (1) status-assessment of the current quality of the groundwater resource;

(2) understanding - identification of the natural and human factors affecting groundwater quality; and (3) trendsdetection of changes in groundwater quality over time (Kulongoski and Belitz, 2004). The assessments are intended to characterize the quality of groundwater in the primary aquifer systems of the study units, not the treated drinking water delivered to consumers by water purveyors. The primary aquifer systems are defined as parts of aquifers corresponding to the depths of the perforation intervals of wells listed in the CDPH databases for the study units. The CDPH database lists wells used for public drinking-water supplies and includes wells from systems classified as community (such as cities, towns, and mobile-home parks), non-transient, non-community (such as those in schools, workplaces, and restaurants), and transient, non-community (such as campgrounds, parks, and highway rest areas). Collectively, the CDPH refers to these wells as "public-supply" wells. Groundwater quality in shallow or very deep parts of the aquifer systems may differ from that in the primary aquifer systems. In particular, shallow groundwater may be more vulnerable to surface contamination. As a result, samples from shallow wells (such as many private domestic wells and environmental monitoring wells) can have greater concentrations of constituents (such as volatile organic compounds [VOCs] and nitrate) from anthropogenic sources than samples from wells screened in the underlying primary aquifer systems (for example, Landon and others, 2010).

All published and quality-assurance/quality-control (QA/QC) approved analytical data collected for the GAMA Program are stored in the web-based Geotracker Database (California State Water Resources Control Board, 2009, website at https://geotracker.waterboards.ca.gov/gama/). The Geotracker Database also stores groundwater-quality data and related reports collected by other State agencies, such as the CDPH, CDWR, and CDPR, and data collected by the SWRCB and Regional Boards from environmental monitoring wells at contaminated and (or) remediated sites.

This report presents water-quality data collected in seven GAMA-PBP study units that were initially sampled from July 2004 to December 2005 and then were resampled from August 2007 to November 2008 to evaluate temporal trends. Data are presented from initial sampling, as well as from resampling for trends in the San Diego Drainages, North San Francisco Bay, Northern San Joaquin Basin, Southern Sacramento Valley, San Fernando-San Gabriel, Monterey Bay and Salinas Valley Basins, and Southeast San Joaquin Valley study units. Data for additional parameters, evaluation of the QC data, and detailed descriptions of these seven GAMA study units can be found in published USGS Data-Series Reports for each study unit (Wright and others, 2005; Kulongoski and others, 2006; Bennett and others, 2006; Dawson and others, 2008; Land and Belitz, 2008; Kulongoski and Belitz, 2007; and Burton and Belitz, 2008, respectively).

\section{Purpose and Scope}

The purposes of this report are to (1) describe the study design and study methods; (2) present the results of QC measurements, and (3) present the results of resampling for an assessment of trends in the first seven GAMA study units. Groundwater samples were analyzed for organic and inorganic constituents, field parameters, and chemical tracers for groundwater source and age. The chemical data presented in this report were evaluated by comparison to State and Federal drinking-water standards. The health-based and non-health-based benchmarks considered for this report are those established by the U.S. Environmental Protection Agency (USEPA) and (or) the CDPH. The data presented in this report are intended to characterize the quality of untreated groundwater resources within the study units and to provide a means to evaluate whether or not the groundwater quality is changing over time. Discussion of the occurrence of the constituents detected in groundwater samples and factors influencing the distribution can be found in published USGS Scientific Investigation Reports for these GAMA-PBP study units (Wright and Belitz, 2011; Kulongoski and others, 2010; Bennett and others, 2010; Bennett and others, 2011; Land and others, 2012; Kulongoski and Belitz; 2011; and Burton and others, 2012, respectively).

\section{Study Units}

Detailed information on the hydrogeologic settings of the seven GAMA-PBP study units discussed in this report, along with descriptions of data collection and analytical results from the first round of sampling of these study units can be found in published USGS Data-Series Reports referenced throughout this report. Only brief descriptions of the study units are presented here. 


\section{San Diego Drainages Study Unit}

The San Diego Drainages study unit (figs. 1, 2) covers approximately 3,900 square miles $\left(\mathrm{mi}^{2}\right)$ in San Diego, Orange, and Riverside Counties and is located in the San Diego Drainages hydrogeologic province (Belitz and others, 2003). The San Diego Drainages study unit consists of four study areas (fig. 2). The Temecula Valley study area lies within the boundaries of the Temecula Valley Groundwater Basin as defined by the CDWR (California Department of Water Resources, 2004a). The Warner Valley study area lies within the boundaries of the Warner Valley Groundwater Basin as defined by the CDWR (California Department of Water Resources, 2004b). The Alluvial Basins study area consists of the 12 CDWR-defined alluvial basins within the San Diego Drainages study unit that have at least one public supply well (California Department of Water Resources, 2003; 2004c, d). The Hard Rock study area consists of areas within the San Diego Drainages hydrogeologic province that are outside of CDWR-defined groundwater basins and within a radius of 3 kilometers $(\mathrm{km})$ of a CDPH well. Descriptions of the hydrogeologic settings of the San Diego Drainages study unit, its groundwater basins, and its individual study areas are given by Wright and others (2005).

\section{North San Francisco Bay Study Unit}

The North San Francisco Bay study unit (figs. 1, 3) covers approximately $1,000 \mathrm{mi}^{2}$, mostly in Napa, Sonoma, and Marin Counties, and lies within the Northern Coast Ranges hydrogeologic province (Belitz and others, 2003). For the purpose of this study, the seven CDWR-defined groundwater basins that lie within the North San Francisco Bay study unit were grouped into three study areas (fig. 3). The Valley and Plains study area includes most of the alluvial-filled basins in the study unit. The Volcanic Highlands study area includes the hilly to mountainous areas of Pliocene volcanic deposits. The Wilson Grove Formation Highlands study area is characterized by gently rolling hills, broad valleys, and rounded hilltops and lies closer to the coast than the other two study areas. The hydrogeologic settings of the North San Francisco Bay study unit, its groundwater basins, and its individual study areas are described by Kulongoski and others (2006).

\section{Northern San Joaquin Basin Study Unit}

The Northern San Joaquin Basin study unit (figs. 1, 4) covers approximately 2,079 $\mathrm{mi}^{2}$ in San Joaquin, Alameda, Amador, Calaveras, Contra Costa, Sacramento, and Stanislaus Counties, and lies within the Central Valley hydrogeologic province (Belitz and others, 2003). The study unit consists of three CDWR-defined groundwater subbasins located within the San Joaquin Valley Groundwater Basin: the Eastern San Joaquin subbasin (California Department of Water Resources, 2006a), the Tracy subbasin (California Department of Water Resources, 2006b), and the Cosumnes subbasin (California Department of Water Resources, 2006c). For the purpose of this study, the Northern San Joaquin Basin study unit was divided into four study areas (fig. 4). The Tracy Basin study area lies within the boundaries of the Tracy subbasin. The Cosumnes Basin study area covers about half of the area within the boundaries of the Cosumnes subbasin. The Eastern San Joaquin Basin study area covers about two-thirds of the Eastern San Joaquin subbasin. The Uplands Basin study area is defined as those portions of the Eastern San Joaquin and Cosumnes subbasins that represent the exposed areal extent of semiconsolidated deposits of Pliocene and Pleistocene age west of the consolidated bedrock of the Sierra Nevada Mountains. The hydrogeologic settings of the Northern San Joaquin Basin study unit, its groundwater basin and subbasins, and its individual study areas are described by Bennett and others (2006).

\section{Southern Sacramento Valley Study Unit}

The Southern Sacramento Valley study unit (figs. 1, 5) covers approximately $2,100 \mathrm{mi}^{2}$ in Placer, Sacramento, Solano, Sutter, and Yolo Counties. It lies mostly within the Central Valley hydrogeologic province, and partly within the Northern Coast Ranges hydrogeologic province (Belitz and others, 2003). The study unit consists of the CDWR-defined Suisun-Fairfield Groundwater Basin (California Department of Water Resources, 2003) and four CDWR-defined groundwater subbasins located within the Sacramento Valley Groundwater Basin: the North American subbasin (California Department of Water Resources, 2006d), the South American subbasin (California Department of Water Resources, 2004e), the Solano subbasin (California Department of Water Resources, 2004f), and the Yolo subbasin (California Department of Water Resources, 2004g). For the purpose of this study, the Southern Sacramento Valley study unit was divided into six study areas (fig. 5). The North American study area covers about two-thirds of the North American subbasin. The South American study area covers about three-quarters of the South American subbasin. The Solano study area lies within the boundaries of the Solano subbasin. The Suisun-Fairfield study area lies within the boundaries of the Suisun-Fairfield Groundwater Basin. The Yolo study area lies within the boundaries of the Yolo subbasin. The Uplands Basin study area is defined as those portions of the North American and South American subbasins that represent the exposed areal extent of semiconsolidated deposits of Pliocene and Pleistocene age west of the consolidated bedrock of the Sierra Nevada Mountains. The hydrogeologic settings of the Southern Sacramento Valley study unit, its groundwater basins and subbasins, and its individual study areas are described by Dawson and others (2008). 


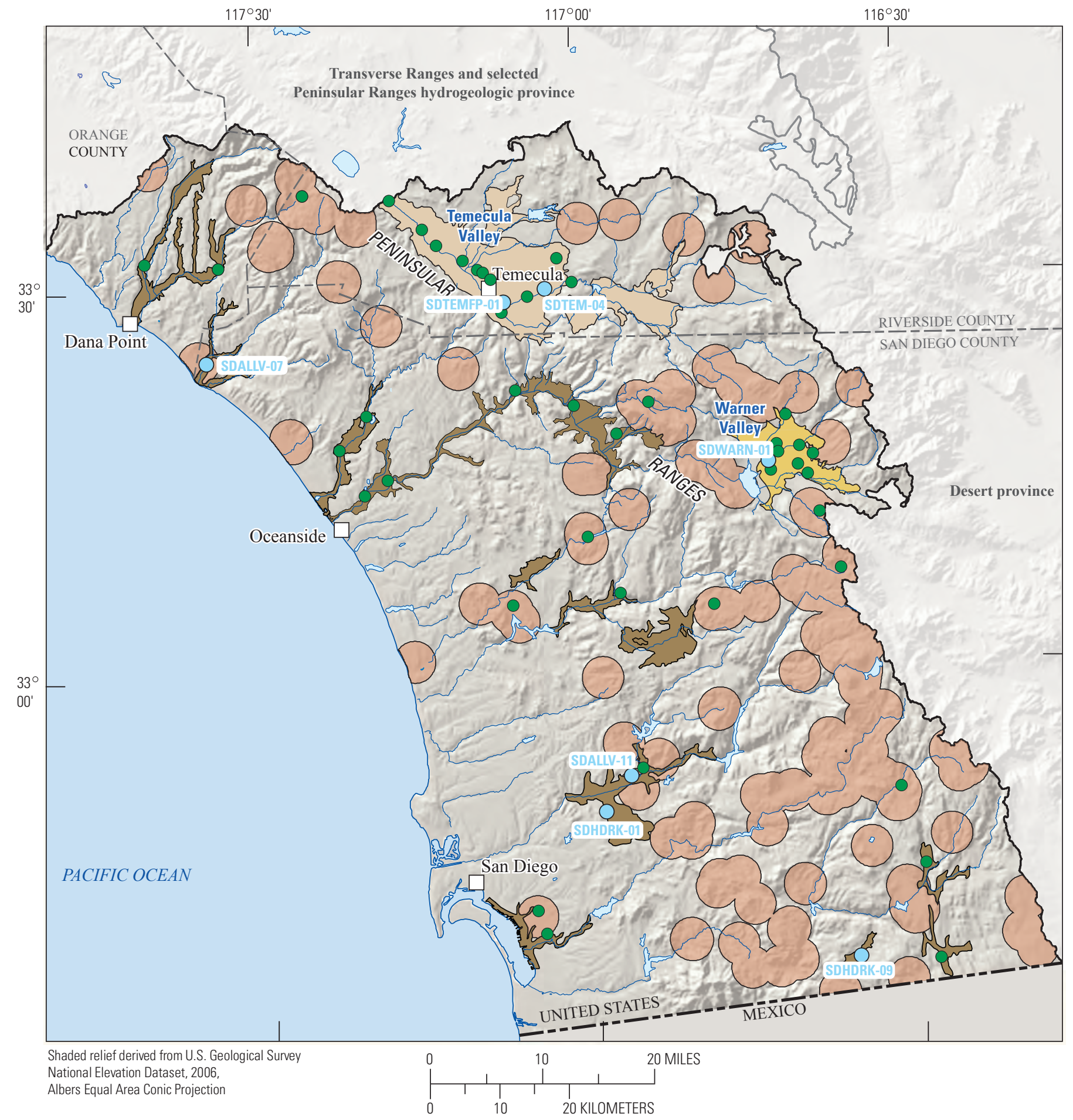

San Diego Drainages study unit

Study
area $\left\{\begin{array}{lllll}\text { Temecula Valley } & \text { Alluvial Basins } & \square \text { Study unit boundary } & \bigcirc & \text { Trend well } \\ \text { Warner Valley } & \text { Hard Rock } & \text { Status well }\end{array}\right.$

Figure 2. San Diego Drainages Groundwater Ambient Monitoring and Assessment (GAMA) study unit with locations of study areas, status wells, and trend wells. 


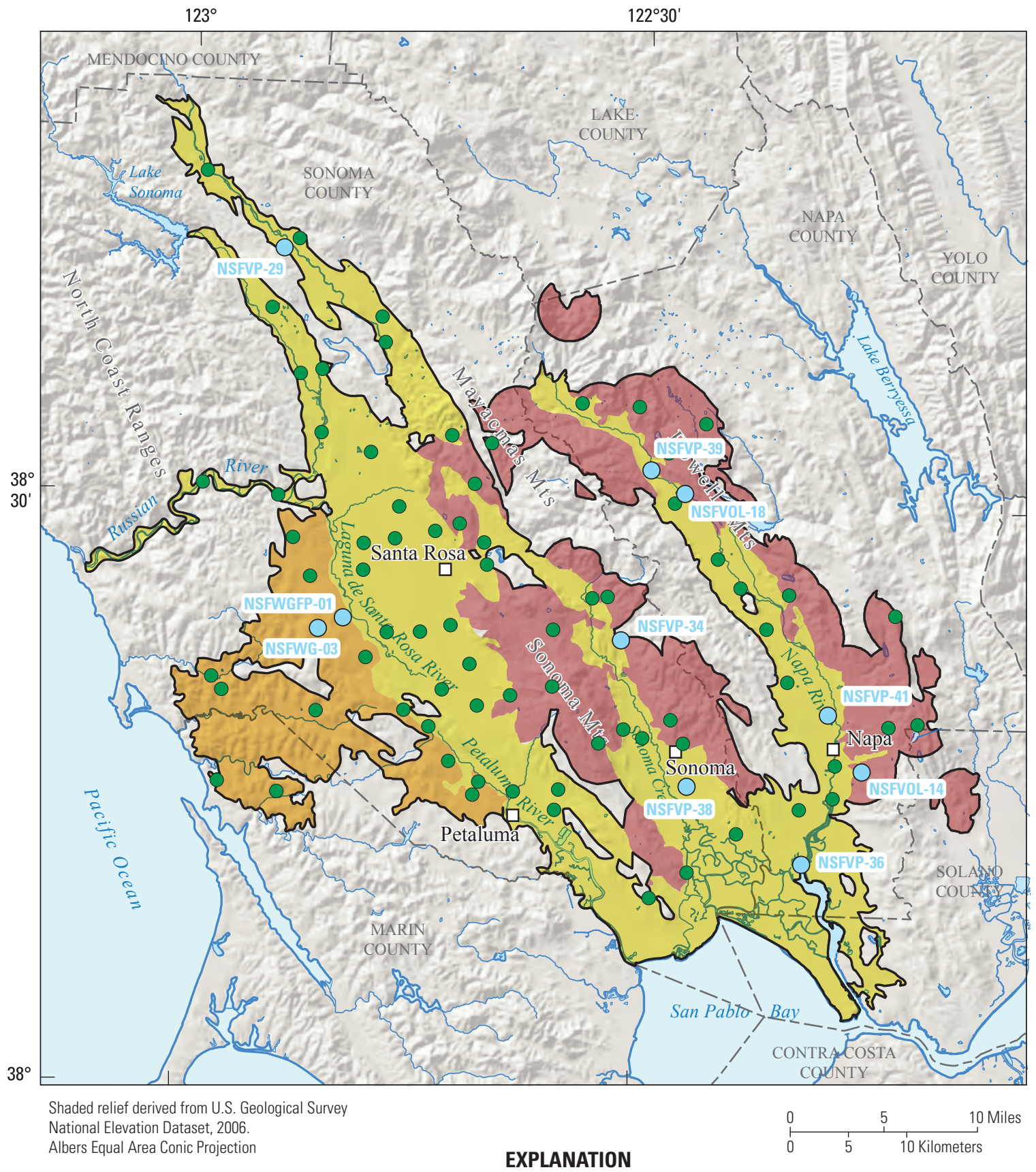

North San Francisco Bay study unit

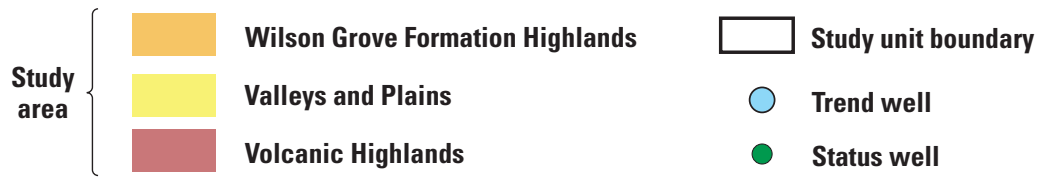

Figure 3. North San Francisco Bay Groundwater Ambient Monitoring and Assessment (GAMA) study unit with locations of study areas, status wells, and trend wells. 


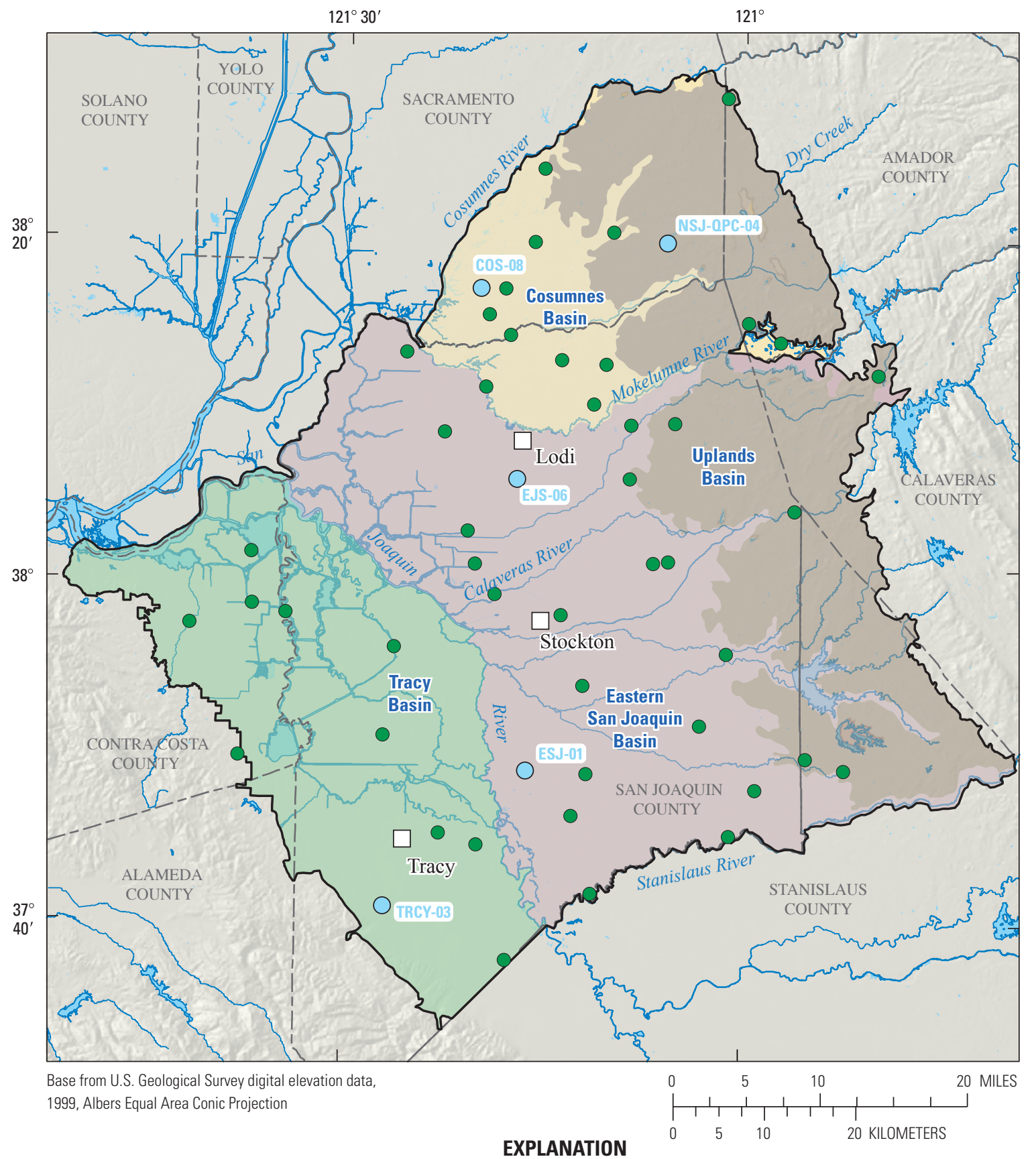

Northern San Joaquin Basin study unit
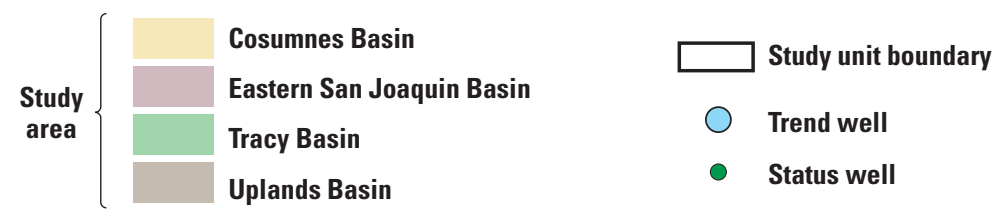

Figure 4. Northern San Joaquin Basin Groundwater Ambient Monitoring and Assessment (GAMA) study unit with locations of study areas, status wells, and trend wells. 


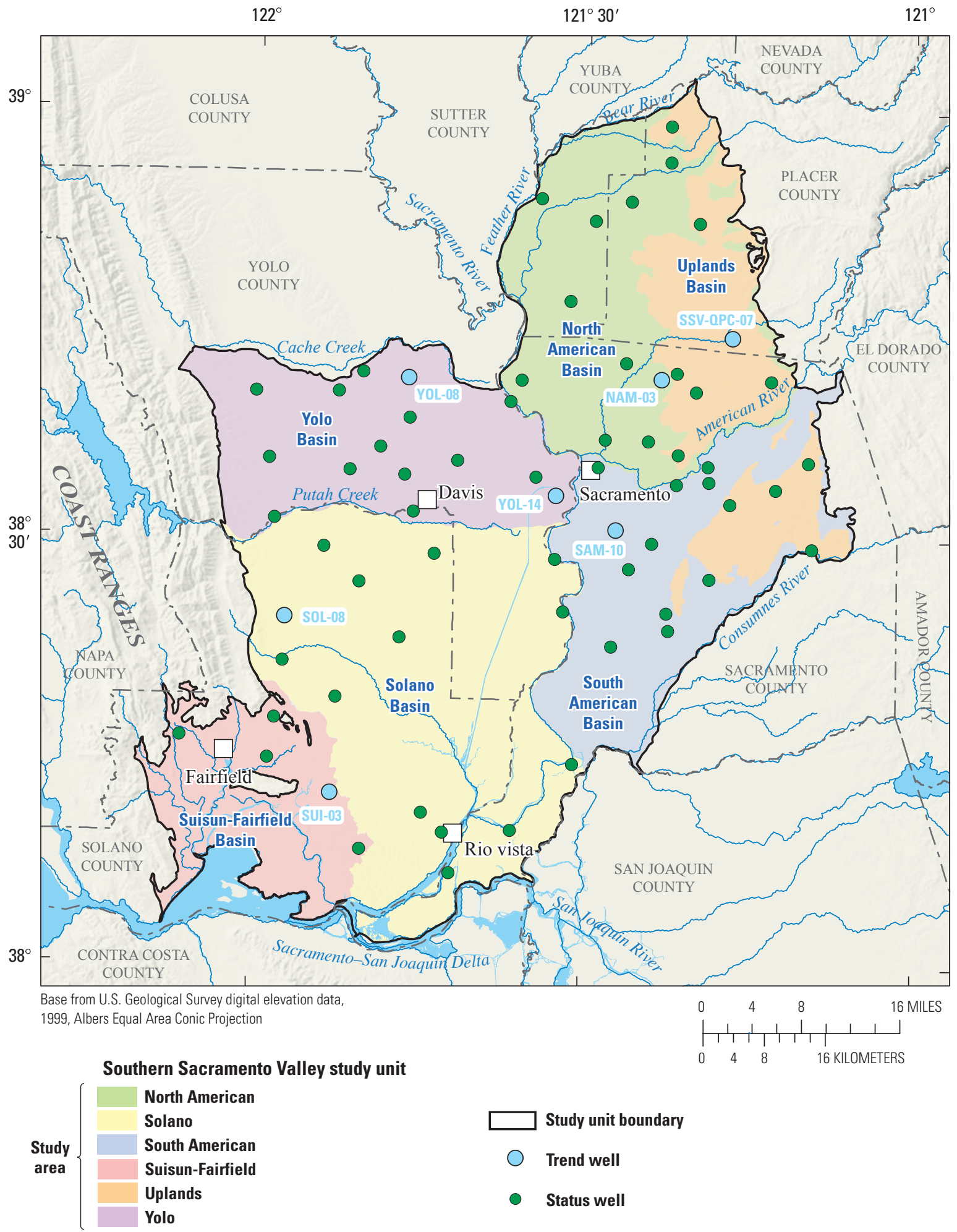

Figure 5. Southern Sacramento Valley Groundwater Ambient Monitoring and Assessment (GAMA) study unit with locations of study areas, status wells, and trend wells. 


\section{San Fernando-San Gabriel Study Unit}

The San Fernando-San Gabriel study unit (figs. 1, 6) covers approximately $500 \mathrm{mi}^{2}$ in Los Angeles County and lies within the Transverse Range and selected Peninsular Ranges hydrogeologic province (Belitz and others, 2003). The study unit consists of three CDWR-defined groundwater basins: the San Fernando Valley Groundwater Basin (California Department of Water Resources, 2004h), the San Gabriel Valley Groundwater Basin (California Department of Water Resources, 2004i), and the Raymond Groundwater Basin (California Department of Water Resources, 2004j). For the purpose of this study, the San Fernando-San Gabriel study unit was divided into two study areas (fig. 6). The San Fernando study area lies within the boundaries of the San Fernando Valley Groundwater Basin, and the San Gabriel study area combines the boundaries of the San Gabriel Valley and Raymond Groundwater Basins. The hydrogeologic settings of the San Fernando-San Gabriel study unit, its groundwater basins, and its individual study areas are described by Land and Belitz (2008).

\section{Monterey Bay and Salinas Valley Basins Study Unit}

The Monterey Bay and Salinas Valley Basins study unit (figs. 1, 7) covers approximately 1,000 $\mathrm{mi}^{2}$ in Monterey, Santa Cruz, and San Luis Obispo Counties and lies within the Southern Coast Ranges hydrogeologic province (Belitz and others, 2003). The study unit consists of eight CDWRdefined groundwater basins. For the purpose of this study, the Monterey Bay and Salinas Valley Basins study unit was divided into four study areas (fig. 7).

The Santa Cruz study area combines five CDWR-defined groundwater basins: the Felton Area Groundwater Basin (California Department of Water Resources, 2004k), the Scotts Valley Groundwater Basin (California Department of Water Resources, 2006e), the Santa Cruz Purisima Formation Highlands Groundwater Basin (California Department of Water Resources, 20041), the West Santa Cruz Terrace Groundwater Basin (California Department of Water Resources, 2004m), and the Soquel Valley Groundwater Basin (California Department of Water Resources, 2004n).
The Monterey Bay study area consists of the Carmel Valley Groundwater Basin (California Department of Water Resources, 2004o), the Pajaro Valley Groundwater Basin (California Department of Water Resources, 2006f), and five subbasins of the Salinas Valley Groundwater Basin: the Corral de Tierra Area subbasin (California Department of Water Resources, 2004p), the Langley Area subbasin (California Department of Water Resources, 2004q), the Seaside Area subbasin (California Department of Water Resources, 2004r), the Eastside Aquifer subbasin (California Department of Water Resources, 2004s), and the 180/400-Foot Aquifer subbasin (California Department of Water Resources, 2004t).

The Salinas Valley study area consists of two more subbasins of the Salinas Valley Groundwater Basin: the Upper Valley Aquifer subbasin (California Department of Water Resources, 2004u) and the Forebay Aquifer subbasin (California Department of Water Resources, 2004v).

Finally, the Paso Robles study area consists of the low-lying alluvium-fill portions of the Paso Robles Subbasin (California Department of Water Resources, 2004w) of the Salinas Valley Groundwater Basin. The hydrogeologic settings of the Monterey Bay and Salinas Valley Basins study unit, its groundwater basins and subbasins, and its individual study areas are described by Kulongoski and Belitz (2007).

\section{Southeast San Joaquin Valley Study Unit}

The Southeast San Joaquin Valley study unit (figs. 1, 8) covers approximately $3,780 \mathrm{mi}^{2}$ in Fresno, Kings, and Tulare Counties and lies within the Central Valley hydrogeologic province (Belitz and others, 2003). The study unit consists of four CDWR-defined subbasins of the CDWR-defined San Joaquin Valley Groundwater Basin: the Kings subbasin, the Kaweah subbasin, the Tule subbasin, and the Tulare Lake subbasin (California Department of Water Resources, 2006g, $\mathrm{h}, \mathrm{i}$, and $\mathrm{j}$, respectively). For the purpose of this study, the Southeast San Joaquin Valley study unit was divided into four study areas corresponding with the names and boundaries of the four subbasins (fig. 8). The hydrogeologic settings of the Southeast San Joaquin study unit, its groundwater subbasins, and corresponding study areas are described by Burton and Belitz (2008). 


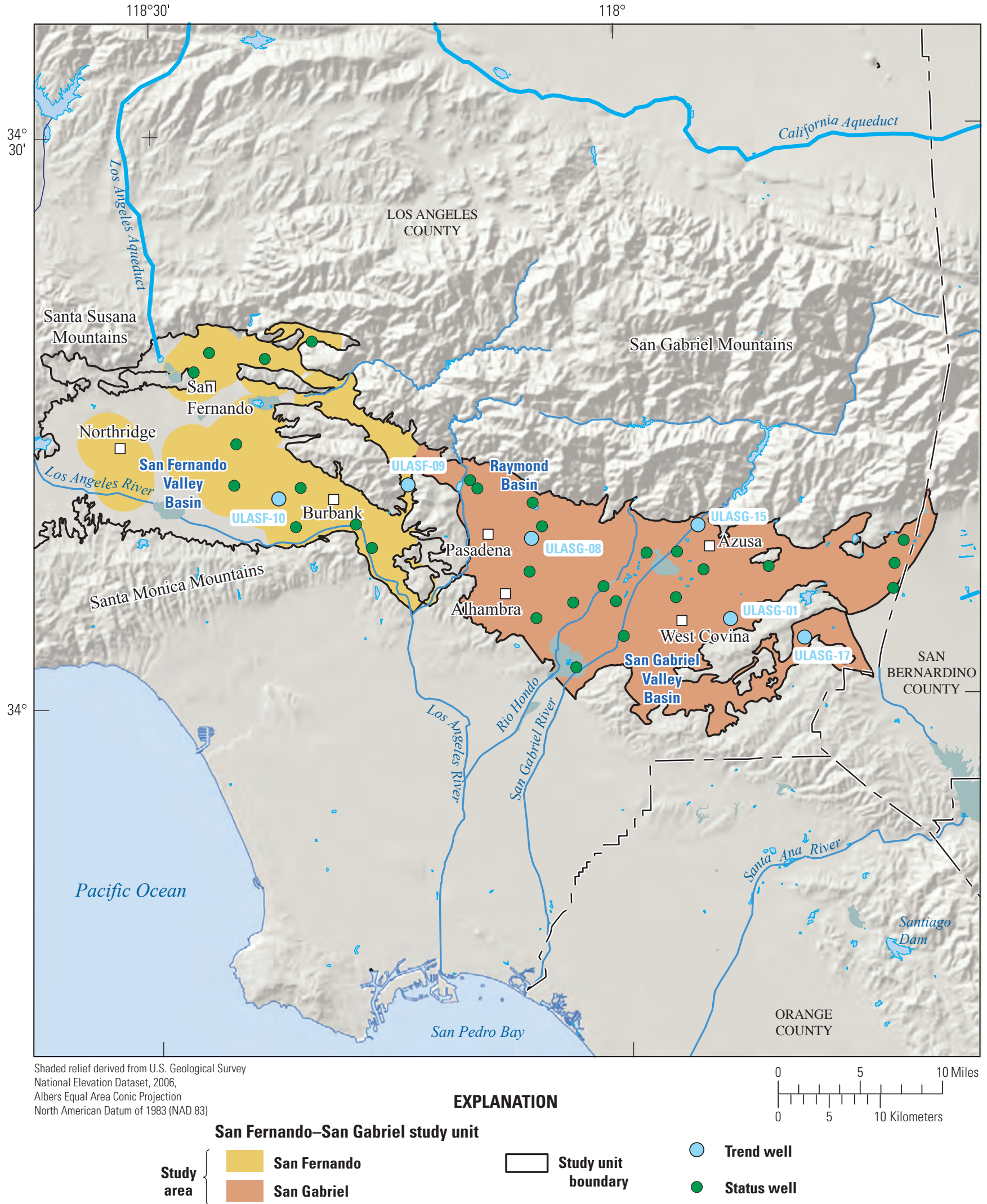

Figure 6. San Fernando-San Gabriel Groundwater Ambient Monitoring and Assessment (GAMA) study unit with locations of study areas, status wells, and trend wells. 


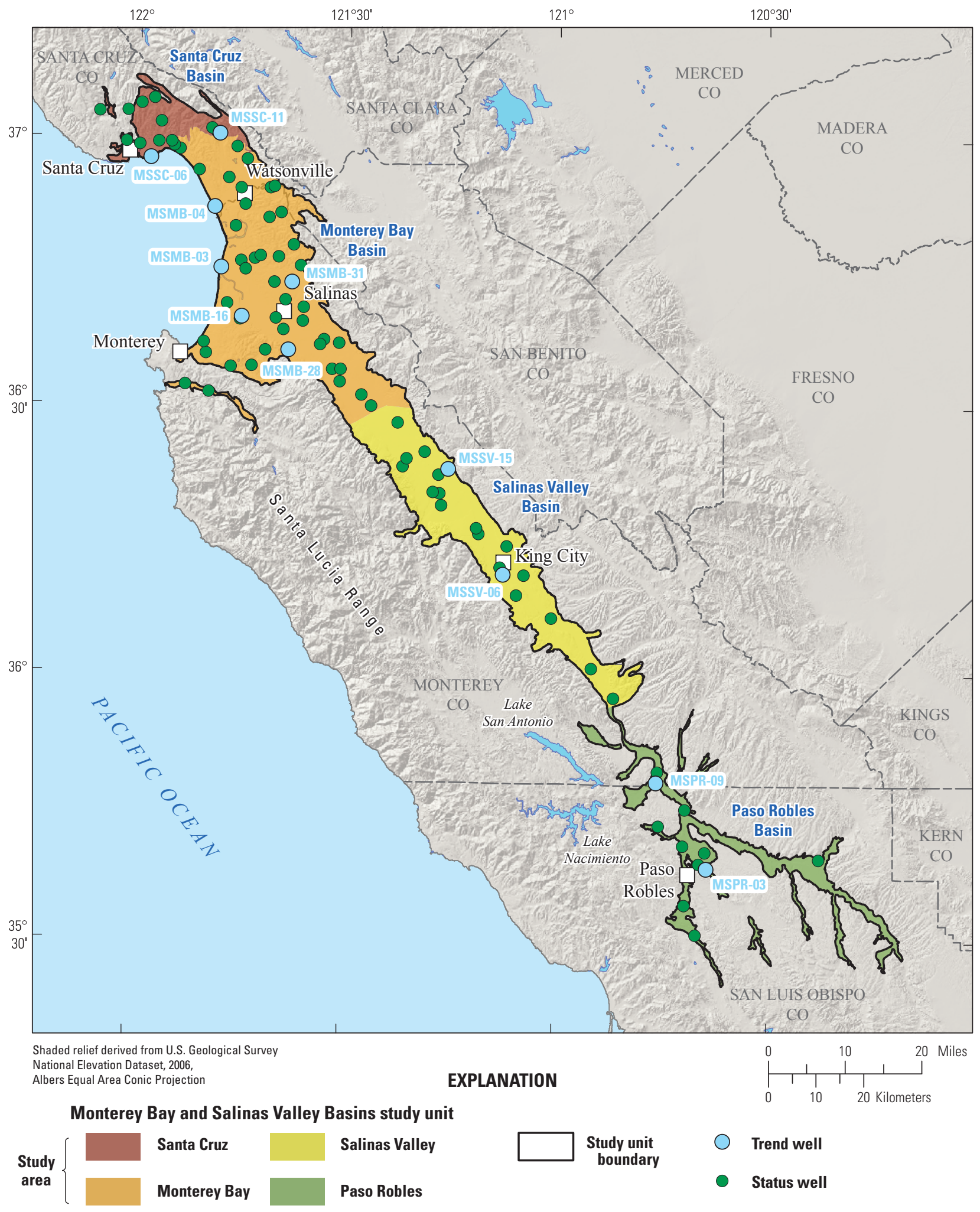

Figure 7. Monterey Bay and Salinas Valley Basins Groundwater Ambient Monitoring and Assessment (GAMA) study unit with locations of study areas, status wells, and trend wells. 


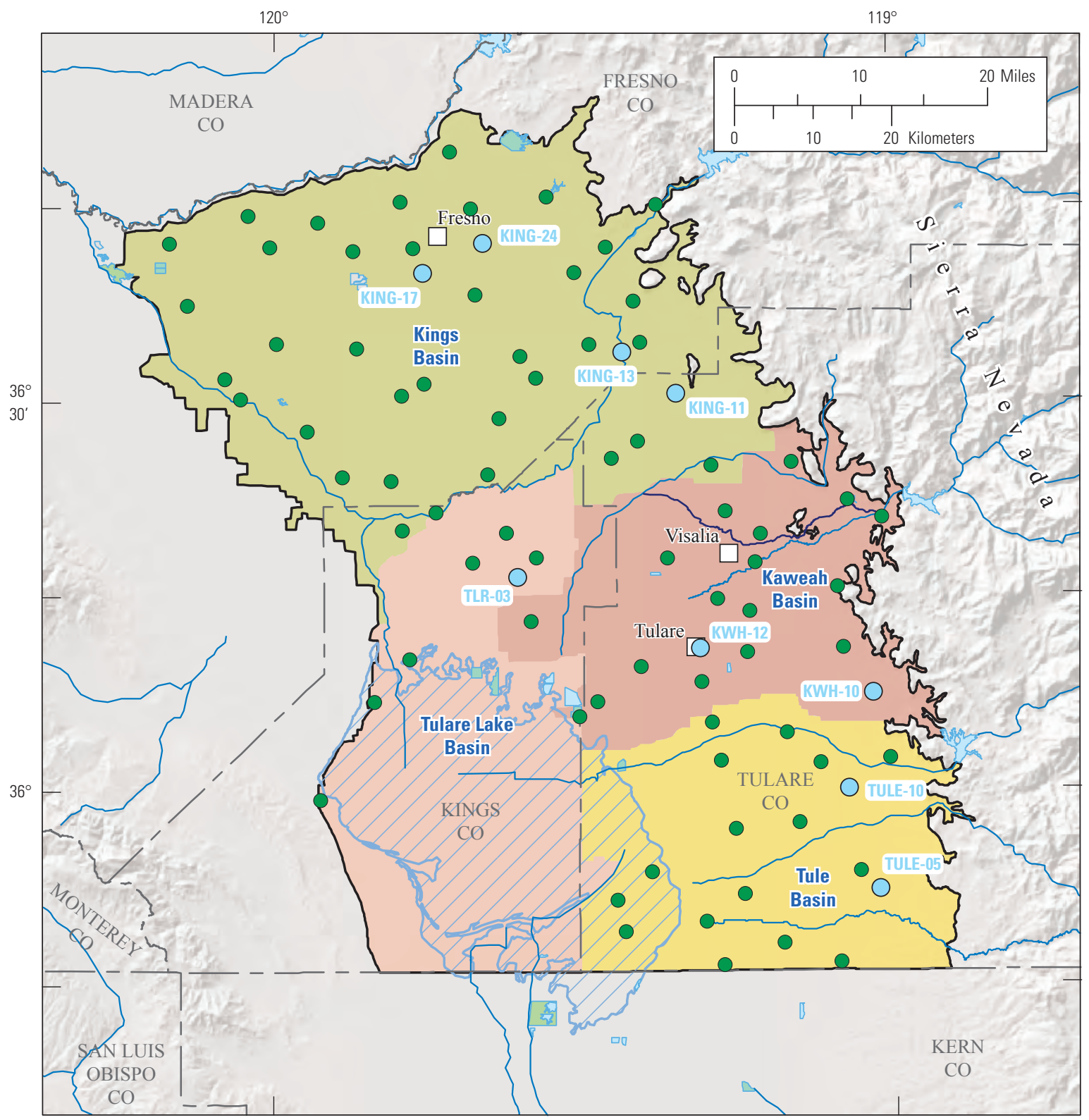

Shaded relief derived from U.S. Geological Survey National Elevation Dataset, 2006,

Albers Equal Area Conic Projection

\section{EXPLANATION}

Southeast San Joaquin Valley study unit

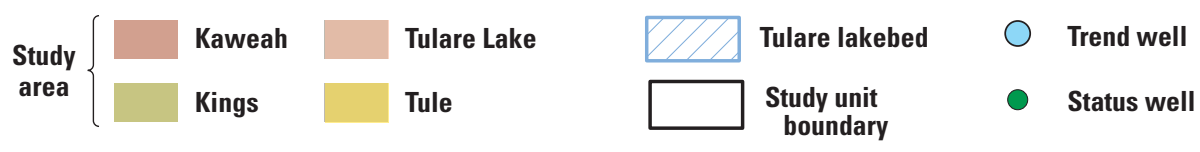

Figure 8. Southeast San Joaquin Valley Groundwater Ambient Monitoring and Assessment (GAMA) study unit with locations of study areas, status wells, and trend wells. 


\section{Methods}

Methods used for the GAMA-PBP were selected to achieve the following objectives: (1) collect groundwater samples that are statistically representative of the primary aquifer system in each study unit; (2) collect samples in a consistent manner; (3) analyze samples by using proven and reliable laboratory methods; (4) assure the quality of the groundwater data; and (5) maintain data securely and with relevant documentation.

The initial sampling was designed to provide a spatially unbiased assessment of the quality of raw groundwater used for public water supplies within the seven study units. Each study area was divided into equal-area grid cells. A total of 570 grid cells were defined in the 27 study areas making up the 7 study units, and the number of grid cells per study area ranged from 10 cells to 60 cells. The CDPH wells within each cell were assigned random ranks, and the highest ranked well that met basic sampling criteria and for which permission to be sampled could be obtained was sampled. For some cells having no available CDPH wells, an irrigation or a domestic well having a perforation interval similar to that of $\mathrm{CDPH}$ wells in the area was sampled. One well was sampled in each of 462 grid cells; the remaining cells contained no wells that were appropriate for sampling and accessible. Wells selected to be sampled in this manner are referred to as grid wells, or status wells, because they are sampled to evaluate the status of groundwater quality in the study unit. In this report, they are referred to as status wells.

Fifty-five status wells were selected for resampling as part of trends analysis. These wells are referred to as trend wells and are a subset of status wells. The basic method for selecting trend wells was to randomly rank the grid wells in each study area and then sample the highest ranked wells. At least 10 percent of the status wells in each study area were resampled (trend wells). Methods for the selection of trend wells evolved during trend sampling of the first seven GAMAPBP study units. After the first few study units, information on well depth and well construction was required in order for a well to be selected as a trend well, and additional criteria were used to ensure an approximately even spatial distribution among the trend wells. Table 1 lists the 55 trend wells by study unit and provides the GAMA alphanumeric identification number, along with the paired sampling dates, land-surface altitude, and construction information (when available) for each well. The wells are identified by the GAMA identification numbers assigned when they were first sampled by the GAMA-PBP.

Fifty-eight wells were sampled in the San Diego Drainages study unit from May through July 2004 (Wright and others, 2005). Fifty-three of these wells were status wells. The other five wells were sampled as part of a flow-path study in the Temecula Valley study area (SDTEMFP-01 through SDTEMFP-05) and are considered to be "understanding wells." After the publication of Wright and others (2005), six additional grid wells were re-classified as "understanding wells" (Wright and Belitz, 2011), including SDHDRK-01 (presently known as SDHRKU-01) which had been selected and sampled as a trend well. Resampling of the San Diego Drainages study unit occurred in September 2007. Seven trend wells were sampled from the four study areas in this study unit (table 1): two each from the Alluvial Basins, Hard Rock, and Temecula Valley study areas, and one from the Warner Valley study area (fig. 2). One of the trend wells selected from the Temecula Valley study area (SDTEMFP-01) was one of a series of wells that were sampled to evaluate changes in groundwater quality along a flow path (understanding wells).

Ninety-seven wells were sampled in the North

San Francisco Bay study unit from August through November 2004 (Kulongoski and others, 2006). Eighty-four of these wells were status wells (the remaining 13 wells were understanding wells). Resampling of the North San Francisco Bay study unit took place during August and November 2007. Ten trend wells were sampled from the three study areas in this study unit (table 1): six trend wells from the Valley and Plains study area, two from the Volcanic Highlands study area, and two from the Wilson Grove Formation Highlands study area (fig. 3). One of the trend wells selected from the Wilson Grove Formation Highlands study area (NSFWGFP-01) was one of a series of wells along a flow path that was sampled to evaluate spatial changes in groundwater quality.

Sixty-four wells were sampled in the Northern San Joaquin Basin study unit from December 2004 through February 2005 (Bennett and others, 2006). Fifty-one of these wells were status wells. Resampling of the Northern San Joaquin Basin study unit took place from March 31 through April 3, 2008. Five trend wells were sampled from the four study areas in the study unit (table 1): one trend well each from the Cosumnes Basin, Tracy Basin, and Uplands Basin study areas, and two trend wells from the Eastern San Joaquin Basin study area (fig. 4).

Eighty-three wells were sampled in the Southern Sacramento Valley study unit from March through June 2005 (Dawson and others, 2008). Sixty-seven of these wells were status wells. Resampling of the Southern Sacramento Valley study unit occurred during April 2008. Seven trend wells were sampled from the six study areas in the study unit (table 1): one trend well each from the North American, South American, Solano, Suisun, and Uplands Basin study areas, and two trends wells from the Yolo study area (fig. 5).

Fifty-two wells were sampled in the San Fernando-San Gabriel study unit from May through July 2005 (Land and Belitz, 2008). Thirty-five of these wells were status wells. Resampling of the San Fernando-San Gabriel study unit occurred during June 2008. Six trend wells were sampled from the two study areas in the study unit (table 1): two trend wells from the San Fernando study area and four trend wells from the San Gabriel study area (fig. 6).

Ninety-seven wells were sampled in the Monterey Bay and Salinas Valley Basins study unit from July through September 2005 (Kulongoski and Belitz, 2007). Ninety-one of these wells were status wells. Resampling of the Monterey 
Bay and Salinas Valley Basins study unit took place in two distinct periods during August and November 2008. Eleven trend wells were sampled from the four study areas in the study unit (table 1): five trend wells from the Monterey Bay study area and two trend wells each from the Santa Cruz, Paso Robles, and Salinas Valley study areas (fig. 7).

Ninety-nine wells were sampled in the Southeast

San Joaquin Valley study unit from October through December 2005 (Burton and Belitz, 2008). Eighty-three of these wells were status wells. Resampling of the Southeast San Joaquin Valley study unit took place in November 2008. Nine trend wells were sampled from the four study areas in the study unit (table 1): four trend wells from the Kings study area, one trend well from the Tulare Lake study area, and two trend wells each from the Kaweah and Tule study areas (fig. 8).

Well locations were verified by using a global positioning system (GPS), 1:24,000-scale USGS topographic maps, well information in USGS and CDPH databases, and information provided by well owners, drillers' logs, and (or) other sources of construction information. Well location and information were recorded in the field by hand on field sheets and electronically on field laptop computers using the Alternate Place Entry (APE) program designed by the USGS. All information was verified and then uploaded into the USGS National Water Information System (NWIS) database. Well owner, well use, and well location are not published.

\section{Sample Collection and Analysis}

Samples were collected by following modified USGS National Field Manual (NFM) (U.S. Geological Survey, variously dated) and modified USGS National Water-Quality Assessment (NAWQA) Program (Koterba and others, 1995) sampling protocols. These sampling protocols were followed so that samples representative of groundwater in the aquifer were collected at each site and so that the samples were collected and handled in ways that minimized the potential for contamination. Following these protocols also allows for comparison of data collected by GAMA-PBP throughout California with other USGS projects in California and the Nation. The methods used for sample collection and analysis are described in the appendix section titled "Sample Collection and Analysis."

Various strategies were used to select constituents for resampling for trends in these seven study units. Trend wells were sampled for between 135 and 262 distinct constituents during the 2007-2008 resampling (table 2). Tables 3A-I list the constituents in each constituent class by name and other identifiers, their primary use or source (when relevant), and their reporting and benchmark levels. Tables 3A-D and $\mathrm{H}$ also indicate whether or not each constituent was detected during sampling or resampling of these study units and, if so, in which of the study units they were detected. Trend samples were analyzed for 85 VOCs (table 3A), between 63 and 81 pesticides and pesticide degradates (table $3 \mathrm{C}$ ), perchlorate (table $3 \mathrm{H}$ ), stable isotopes of hydrogen and oxygen in water (table 3I), and dissolved tritium. Two trend samples collected from wells in the San Diego Drainages study unit (SDTEM-04 and SDWARN-01) were not resampled for pesticides.

Additional analyses were added to this basic set of analyses for selected trend wells in each study unit. Only the additional constituents that were sampled during the 2004-2005 initial sampling and also during the 2007-2008 resampling are reported here.

The additional analyses for selected wells in all seven study units included nutrients (table 3E) and major ions and trace elements (table 3F). Other analyses were added in only one study unit or a few study units. All study units except for the San Diego Drainages and North San Francisco Bay study units added low-level analysis of 1,2,3-trichloropropane (1,2,3-TCP) performed by Weck Laboratories, Inc. (hereinafter referred to as Weck) (table $3 \mathrm{H}$ ). Samples for the San Fernando-San Gabriel and the Monterey Bay and Salinas Valley Basins study units were analyzed for $N$-nitrosodimethylamine (NDMA) by Weck (table $3 \mathrm{H}$ ). The Northern San Joaquin Basin and Southeast San Joaquin Valley study units were sampled for 1,2-dibromo-3-chloropropane (DBCP) and 1,2-dibromoethane (EDB) (table 3B). The North San Francisco Bay, Southern Sacramento Valley, and San Fernando-San Gabriel study units were sampled for polar pesticide compounds (table 3D) in addition to the pesticide compounds that were part of the basic set of analyses (table 3C). The North San Francisco Bay and San FernandoSan Gabriel study units also were sampled for oxidized and reduced species of arsenic and iron (table 3G). The San Fernando-San Gabriel study unit also was sampled for 14 pharmaceutical compounds, but these results are discussed only briefly and are not included in the tables. Finally, all study units except the San Fernando-San Gabriel and the Southeast San Joaquin Valley study units were sampled for carbon isotopes in selected wells (table 3I).

Two methods were used to analyze for pesticides and pesticide degradates in this study. The first method included a basic set of 63 constituents (Schedule 2003) or an expanded number of compounds (70 for Schedule 2032 or 81 for Schedule 2033), depending on the specific laboratory schedule requested when the sample was submitted to the NWQL (table 3C). NWQL Schedules 2003, 2032, and 2033 all use the same analytical method (Zaugg and others, 1995; Sandstrom and others, 2001). The second analytical method for pesticide compounds (NWQL Schedule 2060) included 59 polar pesticide compounds (table 3D) and caffeine. Five of the pesticide compounds on Schedule 2060 were in common with all of the schedules $(2003,2032$, or 2033) of the first method. A sixth compound included on Schedule 2060, carbofuran, was also on the two expanded schedules of the first method (Schedules 2032 and 2033), but was not on Schedule 2003. 
The samples from all but two of the study units included in this study were analyzed by using basic Schedule 2003. The samples from the Southern Sacramento Valley study unit were analyzed by using Schedule 2032, and the samples from the Southeast San Joaquin Valley study unit were analyzed by using Schedule 2033. All samples discussed in this report were analyzed using one of the schedules employing this method except for one sample from the Southern Sacramento Valley study unit during initial sampling in 2005 (SUI-03) and one sample from the San Diego Drainages study unit (SDTEM-04) during resampling in 2007, which were not analyzed for pesticide compounds. Schedule 2060 was used for 19 samples during initial sampling in 2004-2005 and for 23 samples during resampling in 2007-2008; the use of this analytical method varied widely by study unit (tables 2, 6A-B). For all four schedules, the NWQL reports concentrations below LT-MDLs; these concentrations are reported in tables 6A-B, but are not considered detections for the purpose of calculating detection frequencies.

\section{Duplicate Analyses for Selected Constituents}

Fourteen constituents were measured two different ways for some samples for this study. Eight of these constituents were measured by duplicate methods for at least some samples at the USGS National Water Quality Laboratory (NWQL). Atrazine, deethylatrazine, carbaryl, carbofuran, metalaxyl, and tebuthiuron were analyzed by Laboratory Schedules 2003/2032/2033 and 2060; and DBCP and EDB were analyzed by Laboratory Schedules 2020 and 1306. In addition, for some samples, 1,2,3-trichloropropane, arsenic, and iron concentrations were measured by the NWQL, as well as by a laboratory other than the NWQL. Perchlorate was measured by two different outside laboratoriesMontgomery Watson Harza Laboratory (hereinafter referred to as MWH) and Weck - for a few samples collected in the San Diego Drainages and North San Francisco Bay study units. The MWH analyses were performed on unfiltered samples, while the Weck analyses were performed on filtered samples. Finally, water-quality indicator measurements of $\mathrm{pH}$ and specific conductance were performed onsite by USGS field personnel. The NWQL also measured $\mathrm{pH}$ and specific conductance, as part of all samples analyzed for Laboratory Schedule 1948. During initial sampling, a few samples were measured for the additional water-quality indicator alkalinity both in the field and by NWQL. However during resampling, alkalinity was only measured by the NWQL as part of Laboratory Schedule 1948, and therefore is not counted here among constituents receiving duplicate analysis.

\section{Quality-Assurance Procedures}

QA procedures used for this study followed the protocols described in the NFM (U.S. Geological Survey, variously dated) and used by the NAWQA Program (Koterba and others,
1995). The QA plan followed by the NWQL, the primary laboratory used to analyze samples for this study, is described in Pirkey and Glodt (1998) and in Maloney (2005).

\section{Quality-Control Samples}

QC samples collected during resampling of the first seven GAMA study units included blanks, replicates, and matrix spikes. QC samples were collected at more than 20 percent of the trend wells ( 13 of the 55 trend wells). During the trend resampling of some study units, additional wells were sampled within the seven study units for reasons other than trend evaluation (wells not included in table 1). Nine additional QC samples were collected from these additional wells. The results from these additional QC samples were used, along with the results from analysis of QC samples collected at the trend wells, to evaluate potential contamination as well as bias and variability of the data that may have resulted from sample collection, processing, storage, transportation, and laboratory analysis. Surrogate spikes were an additional type of QC, and these were added to all of the groundwater samples collected for analyses of organic compounds. QC results are described in the appendix section titled "Quality-Control Results" and are summarized in appendix tables A3-A6.

On the basis of detections in laboratory and field blanks collected during the seven GAMA-PBP study units covered in this report and subsequent study units, the laboratory reporting levels (LRLs) for 6 VOCs (tables 3A, 5) and 11 inorganic constituents (tables 3F, 10) were adjusted in this report using methods described by Fram and others (2012) and Olsen and others (2010) and are greater than those provided by the NWQL. The GAMA Program refers to these adjusted reporting levels as "study reporting levels" (SRLs).

\section{Comparison Benchmarks}

Concentrations of constituents detected in groundwater samples were compared with USEPA and CDPH regulatory and non-regulatory drinking-water health-based benchmarks and benchmarks established for aesthetic purposes (California Department of Public Health, 2008a, b; U.S. Environmental Protection Agency, 2006, 2009). The chemical data presented in this report are meant to characterize the quality of the untreated groundwater in the trend wells and are not intended to represent the treated drinking water delivered to consumers by water purveyors. The chemical composition of treated drinking water may differ from untreated groundwater because treated drinking water may be subjected to disinfection, filtration, mixing with other waters, and (or) exposure to the atmosphere prior to its delivery to consumers. Comparisons of untreated groundwater to benchmarks are for illustrative purposes only and are not indicative of compliance or noncompliance with drinking-water regulations. The following benchmarks were used for comparisons: 
- MCL_Maximum Contaminant Level. Legally enforceable standards that apply to public-water systems and are designed to protect public health by limiting the levels of contaminants in drinking water. MCLs established by the USEPA are the minimum standards with which States are required to comply, and individual States may choose to set more stringent standards. CDPH has established MCLs for additional constituents not regulated by the USEPA, as well as lowered the benchmark concentration for a number of constituents with MCLs established by the USEPA. In this report, a benchmark set by the USEPA and adopted by the CDPH is labeled "MCL-US," and one set by CDPH that is more stringent than the MCL-US is labeled "MCL-CA." Well owners are notified when constituents are detected at concentrations greater than an MCL-US or an MCL-CA benchmark in samples collected for the GAMA-PBP, but these detections do not constitute violations of CDPH regulations.

- AL-Action Level. Legally enforceable standards that apply to public-water systems and are designed to protect public health by limiting the levels of copper and lead in drinking water. Detections of copper or lead greater than the action-level benchmarks trigger requirements for mandatory water treatment to reduce the corrosiveness of water to water pipes. The action levels established by the USEPA and CDPH are the same; thus, the benchmarks are labeled "AL-US" in this report.

- SMCL-Secondary Maximum Contaminant Level. Non-enforceable standards applied to constituents that affect the aesthetic qualities of drinking water, such as taste, odor, and color, or the technical qualities of drinking water, such as scaling and staining. Both the USEPA and CDPH define SMCLs, but unlike MCLs, SMCLs established by the CDPH are not required to be at least as stringent as those established by the USEPA. SMCLs established by the CDPH are used in this report (SMCL-CA) for all constituents that have SMCL-CA values. The SMCL-US is used for $\mathrm{pH}$ because no SMCL-CA has been defined.

- NL-Notification Level. Health-based notification levels established by CDPH (NL-CA) for some of the constituents in drinking water that lack MCLs. If a constituent is detected at concentrations greater than its NL-CA, California State law requires timely notification of local governing bodies and recommends consumer notification.
- HAL - Lifetime Health Advisory Level. The maximum concentration of a constituent at which its presence in drinking water is not expected to cause any adverse carcinogenic effects for a lifetime of exposure. HALs are established by the USEPA (HAL-US) and are calculated assuming consumption of 2 liters (L) (2.1 quarts) of water per day over a 70 -year lifetime by a 70-kilogram (154-pound) adult and that 20 percent of a person's exposure comes from drinking water.

- RSD5-Risk-Specific Dose. The concentration of a constituent in drinking water corresponding to an excess estimated lifetime cancer risk of 1 in 100,000. RSD5 is an acronym for risk-specific dose at $10^{-5}$. RSD5s are calculated by dividing the $10^{-4}$ cancer risk concentration established by the USEPA by 10 (RSD5-US).

For constituents with regulatory benchmarks (MCLs or ALs), detections in groundwater samples were compared to the MCL-US, MCL-CA, or AL-US. Constituents with SMCLs were compared with the SMCL-CA. For chloride, sulfate, specific conductance, and TDS, the CDPH defines a "recommended" and an "upper" SMCL-CA; detections of these constituents in groundwater samples were compared with both levels. The SMCL-USs for these constituents correspond to the recommended SMCL-CAs. Detected concentrations of constituents without an MCL or SMCL were compared to the NL-CA. For constituents without an MCL, SMCL, or NL-CA, detected concentrations were compared with the HAL-US. For constituents without an MCL, SMCL, NL-CA, or HAL-US, detected concentrations were compared with the RSD5-US. Note that using this hierarchy to select the comparison benchmark for a constituent with more than one type of established benchmark will not necessarily result in selection of the benchmark with the lowest concentration. For example, for zinc the SMCL-CA is 5,000 micrograms per liter $(\mu \mathrm{g} / \mathrm{L})$ and the HAL-US is $2,000 \mu \mathrm{g} / \mathrm{L}$, but the comparison benchmark selected by this hierarchy is the SMCL-CA. The comparison benchmarks used in this report are listed in tables 3A-I for all constituents and in tables 4-12 for constituents detected in groundwater samples collected for this trends study. Not all constituents analyzed have established benchmarks available. Detections of constituents at concentrations greater than the selected comparison benchmark are marked with asterisk (*) in tables 4, 5, and $7-11$. 


\section{Water-Quality Results}

Results from analyses of groundwater samples from this study are presented in tables 4-12. During resampling of trend wells, 288 water-quality parameters were measured, including water-quality indicators measured onsite and at the NWQL. However, as noted earlier in "Duplicate Analyses for Selected Constituents," 14 of the constituents were analyzed for some samples by using two different methods. Therefore, although up to 288 water-quality measurements could have been made on each sample collected during resampling for trends, 274 of these measurements are unique water-quality constituents.

Samples collected during the initial sampling of the trend wells were analyzed for additional constituents. The results for constituents not analyzed during resampling are not presented in this report, with one exception. Alkalinity measurements during resampling were made only by the NWQL and not in the field. In contrast, most samples collected during initial sampling were not submitted for determination of alkalinity by the NWQL. Therefore, field-measured alkalinity results from initial sampling are presented for comparison with laboratory alkalinity results from resampling. Indirect estimates of carbonate and bicarbonate concentrations were calculated from the laboratory alkalinity and $\mathrm{pH}$ values using the advanced speciation method (http://or.water.usgs.gov/alk/ methods.html) with $\mathrm{pK}_{1}=6.35, \mathrm{pK}_{2}=10.33$, and $\mathrm{pK}_{\mathrm{W}}=14$.

Groundwater samples collected from the 55 trend wells during initial sampling in 2004-2005 were analyzed for between 90 and 279 of the total parameters possible (median 172) (table 2). Groundwater samples collected from these wells during resampling in 2007-2008 were analyzed for between 135 and 262 of the parameters (median 219) (table 2). One-hundred and seventy-eight of the constituents were undetected in all samples collected from trend wells during both sampling periods (tables 3A-I). Tables 4-12 present paired results of the samples collected from the 55 trend wells during the two sampling periods for constituents that were detected in at least one sample. Constituents listed in tables $3 \mathrm{~A}-\mathrm{I}$ that were not detected in any samples are not included in tables 4-12, with one exception. NDMA was not detected in any of the samples, but is included in table 7 because the decision to analyze for NDMA in samples from selected wells was often made independently from the other constituents of special interest, and its inclusion in table 7 allows the reader to easily determine which samples were analyzed for NDMA.

Table 4 lists water-quality indicators measured in the field and at the NWQL, and tables 5-12 present the results of groundwater analyses organized by compound classes:

- Organic constituents

- Volatile organic compounds and gasoline components (table 5)

- Pesticides and pesticide degradates (tables 6A, B)
- Constituents of special interest (table 7)

- Inorganic constituents

- Nutrients (table 8)

- Major and minor ions, silica, and total dissolved solids (table 9)

- Trace elements (table 10)

- Arsenic and iron species (table 11)

- Isotopic tracers (table 12)

\section{Water-Quality Indicators}

Measurements of dissolved oxygen, $\mathrm{pH}$, specific conductance, alkalinity, and associated parameters (water temperature and bicarbonate and carbonate concentrations) are presented in table 4. Dissolved oxygen, alkalinity, bicarbonate, and carbonate concentrations are used as indicators of natural processes that affect water chemistry. The $\mathrm{pH}$ value indicates the acidity of the water. Specific conductance is the measure of electrical conductivity of the water and is proportional to the amount of dissolved solids in the water.

The specific conductance of all samples was measured in the field. Specific conductance was also measured for more than half of the samples by the NWQL as part of Schedule 1948 (table 4). In all cases where specific conductance was measured both in the field and by the laboratory, the field and laboratory measurements were comparable.

During resampling in 2007-2008, 12 wells had specific conductance values greater than the recommended SMCL-CA of 900 microsiemens per centimeter at 25 degrees Celsius $\left(\mu \mathrm{S} / \mathrm{cm}\right.$ at $\left.25^{\circ} \mathrm{C}\right)$, and all study units except the Southeast San Joaquin study unit had at least one well with specific conductance greater than this benchmark (table 4). In addition, two wells in the San Diego Drainages study unit and one well in the Southern Sacramento Valley study unit had specific conductance values greater than the upper SMCL-CA of $1,600 \mu \mathrm{S} / \mathrm{cm}$ at $25^{\circ} \mathrm{C}$. All wells that had specific conductance above the recommended SMCL-CA in 2007-2008 also had specific conductance greater than this recommended benchmark during initial sampling in 2004-2005. However, specific conductance in a well in the Southeast San Joaquin Valley study unit (TULE-05) that had been greater than the recommended SMCL-CA in 2005 was measured at less than this lower benchmark in 2008. Both wells in the San Diego Drainages study unit that had specific conductance values greater than the upper SMCL-CA in 2007 also had values greater than this upper benchmark in 2004. Specific conductance in the well in the Southern Sacramento Valley study unit that was greater than the upper SMCL-CA in 2008 (YOL-14) was between the lower and upper benchmarks in 2005 . 
The $\mathrm{pH}$ of all samples collected during 2007-2008 was measured in the field. The $\mathrm{pH}$ of most of these samples was also measured by the NWQL as part of Schedule 1948 (table 4). In contrast, $\mathrm{pH}$ was measured in the field and (or) laboratory for only 24 trend wells during the initial sampling in 2004-2005. With few exceptions, $\mathrm{pH}$ values were within the SMCL-US acceptable range $(>6.5$ and $<8.5)$ during both sampling periods (table 4). In most cases where $\mathrm{pH}$ was measured in the field and by the laboratory, the field and laboratory measurements were comparable; however, field and laboratory measurements of $\mathrm{pH}$ differed substantially for three samples collected during the initial sampling in 2004-2005. For samples collected from a well in the Northern San Joaquin Basin study unit (TRCY-03) and from a well in the San Fernando-San Gabriel study unit (ULASG-08), it appears that the laboratory measurements of $\mathrm{pH}$ for the samples collected in 2005 from these wells are unusually low, based on other measurements of $\mathrm{pH}$ in samples from these wells. On the other hand, the field measurement of $\mathrm{pH}$ for a sample collected in 2005 from a well in the Southern Sacramento Valley study unit (YOL-14) seems suspiciously low when compared to the laboratory measurement of this sample and $\mathrm{pH}$ measurements for the sample collected from this well in 2008. In addition, the difference between the values for specific conductance measured in the field and in the laboratory was greater for this 2005 sample than for any other sample represented in this report. Therefore, field measurements may have been recorded for this sample before the well was sufficiently purged.

\section{Organic Constituents}

Organic constituents typically are chemicals that enter water through human activities. The two broad categories of organic constituents discussed in this report are volatile organic compounds and pesticides (including pesticide degradates). VOCs are present in paints, solvents, fuels, fuel additives, refrigerants, fumigants, and disinfected water, and are characterized by their tendency to evaporate. VOCs generally persist longer in groundwater than in surface water because groundwater is isolated from the atmosphere. Pesticides are chemicals used to control weeds, insects, fungi, and other pests in agricultural, urban, and suburban settings, and include herbicides, insecticides, and fungicides. Pesticide degradates are the product of the environmental transformations of the parent pesticide, and they can have similar properties to the parent pesticide (Andreu and Pico, 2004).

\section{Volatile Organic Compounds}

Of the 85 VOCs analyzed by NWQL Schedule 2020, 25 were detected in at least 1 groundwater sample from the trend wells during initial sampling or resampling. Two of these 25 detected VOCs-DBCP and 1,2,3-TCP-were analyzed, but not detected using Schedule 2020. They were only detected by alternative methods that had lower detection limits than did Schedule 2020 for these compounds (tables 3B, $3 \mathrm{H}, 5,7)$. NWQL Schedule 1306 was used to analyze for low levels of DBCP in the Northern San Joaquin Basin and Southeast San Joaquin Valley study units during resampling in 2008. Low-level analyses for 1,2,3-TCP were performed on samples from all study units by MWH during initial sampling in 2004-2005 and by Weck during resampling in 2007-2008.

Nearly all VOC detections were less than health-based benchmarks, and most were less than one-tenth of the benchmarks. However, the solvents tetrachloroethene (PCE) and trichloroethene (TCE) were detected at concentrations greater than their respective MCLs in samples from two wells, and the fumigant $\mathrm{DBCP}$ and the gasoline oxygenate methyl tert-butyl ether (MTBE) were detected in samples from one well each at concentrations greater than their respective MCLs (table 5). Concentrations of PCE and TCE that were greater than the MCLs in the sample collected from a trend well in the San Diego Drainages study unit (SDHDRK-01) in 2007 were similar to the concentrations in the sample collected from this well in 2004. In contrast, the concentrations of PCE and TCE that were greater than the MCLs in a sample collected from a trend well in the San Fernando-San Gabriel study unit (ULASG-17) in 2008 were substantially greater than they had been in the sample collected from this well in 2004. The concentration of DBCP greater than the MCL-US in a trend well in the Southeast San Joaquin study unit (KING-24) in 2008 was similar to the concentration detected in this well in 2005. In contrast, the MTBE concentration greater than the MCL-CA in a trend well in the San Diego Drainages study unit (SDALLV-11) in 2004 was more than 10 times the concentration detected in this well in 2007.

Five VOCs were detected in more than 10 percent of the trend wells during both sampling periods. These were the trihalomethanes (byproducts of drinking-water disinfection) chloroform and bromodichlormethane, and the solvents PCE, TCE, and cis-1,2-dichloroethene. These five compounds are among the most commonly detected VOCs in groundwater nationally (Zogorski and others, 2006). Carbon tetrachloride, another VOC commonly detected in groundwater nationally (Zogorski and others, 2006), was detected in more than 10 percent of the trend wells during initial sampling in 2004 2005, but was detected in fewer than 10 percent of the trend wells during resampling in 2007-2008. The other 21 VOCs detected in trend well samples were detected in fewer than 10 percent of the wells during both sampling periods (table 5).

In addition to the 25 VOCs considered detected for the purposes of statistical summaries, 6 other VOCs (ethylbenzene, toluene, 1,2,3-trimethylbenzene, 1,2,4-trimethylbenzene, $m+p$-xylene, and $o$-xylene) were observed in at least 1 trend well at concentrations less than their long-term method detection limits (LT-MDLs) or SRLs (table 5) (see appendix section on Data Reporting). Such concentrations are not considered detections for the purposes of statistical summaries in this report because of the reduced confidence at such low levels. However, these concentrations less than the LT-MDLs or SRLs are reported in table 5 for completeness. 


\section{Pesticide Compounds}

Of the 132 unique pesticides and pesticide degradates analyzed, 16 were detected in groundwater samples; all detections were at concentrations less than one-tenth of the health-based benchmarks (tables 6A-B). Half (8) of the pesticide compounds that were detected in trend wells were only detected in a single sample during either the initial sampling in 2004-2005 or the resampling in 2007-2008. Thirteen pesticide compounds were detected using Schedule 2003 (or one of its expanded versionsSchedules 2032 or 2033): atrazine, deethylatrazine, dacthal (DCPA), 3,4-dichloroaniline, 3,5-dichloroaniline, $S$-Ethyl depropylthio-carbamate (EPTC), fipronil, desulfinyl fipronil, fipronil sulfide, hexazinone, prometon, simazine, and tebuthiuron. Six pesticide compounds were detected using Schedule 2060: atrazine, deethylatrazine, deisopropylatrazine, diuron, sulfometuron methyl, and tebuthiuron. Three compounds analyzed in common by the two methods were detected by both: atrazine, deethylatrazine, and tebuthiuron (tables 6A-B). Although not a pesticide, caffeine was analyzed by Schedule 2060. Caffeine was detected in samples collected from three trend wells during initial sampling, but was not detected in any of the wells that were resampled using Schedule 2060.

The herbicides atrazine, simazine, and deethylatrazine (a degradate of atrazine) were detected in more than 10 percent of the trend-well samples during both sampling periods, although all three were detected more frequently during initial sampling in 2004-2005. These three compounds are among the most commonly detected pesticide compounds in groundwater nationally (Gilliom and others, 2006). Concentrations of the detected pesticide compounds were similar between the two sampling periods (no obvious trend) and, for compounds analyzed by both methods, the detected concentrations between the two methods were generally similar (tables 6A-B).

\section{Constituents of Special Interest}

Perchlorate, NDMA, and 1,2,3-TCP were defined as constituents of special interest at the beginning of the GAMA-PBP in 2004 because they began to be detected in groundwater in the late 1990s after advances in analytical methods resulted in lower detection limits and because they were considered to have the potential to adversely affect drinking-water quality in California (California Department of Public Health, 2008b). An MCL-CA benchmark was established for perchlorate in 2007. Analyses for these constituents were performed by MWH laboratory during initial sampling in 2004-2005 and by Weck and MWH during resampling in 2007-2008.
Perchlorate was analyzed for 36 trend wells during initial sampling in 2004-2005 and at all 55 trend wells during resampling in 2007-2008 (tables 3H, 7). Perchlorate analyses during initial sampling in 2004-2005 were performed by MWH on unfiltered samples, with a reporting level of $0.5 \mu \mathrm{g} / \mathrm{L}$. Perchlorate analyses during resampling in 2007 2008 were performed by Weck on filtered samples, with a lower reporting level of $0.1 \mu \mathrm{g} / \mathrm{L}$. Perchlorate was detected at concentrations greater than the MCL-CA of $6 \mu \mathrm{g} / \mathrm{L}$ in two trend wells, both in the San Fernando-San Gabriel study unit (ULASG-01 and ULASG-17) during resampling in 2008 (table 7). Samples from these two wells were not analyzed for perchlorate in 2005, and perchlorate was not detected in any other trend wells at concentrations greater than the MCL-CA during initial sampling in 2004-2005.

Samples collected from the San Fernando-San Gabriel and Monterey Bay and Salinas study units were analyzed for NDMA during resampling in 2007-2008. NDMA was analyzed for in selected wells during initial sampling in 20042005 in all seven study units included in this report. NDMA was not detected in any of the samples during either sampling period. NDMA data, which were collected from selected wells in different study units according to study unit design criteria, are included in table 7 to allow the reader to easily determine the wells with samples analyzed for NDMA.

Samples from both sampling periods were analyzed for 1,2,3-TCP as part of NWQL Schedule 2020 with a reporting limit ranging from 0.12 to $0.18 \mu \mathrm{g} / \mathrm{L}$ (table $3 \mathrm{~A}$ ), and it was not detected above the LT-MDL in any sample analyzed by this method (table 5). Because it is a constituent of special interest, a low-level analysis for 1,2,3-TCP, with a reporting level of $0.005 \mu \mathrm{g} / \mathrm{L}$, was performed for selected samples of all study units included in this report except for the San Diego Drainages study unit (tables 2, 7). A total of 25 trend wells during the initial sampling, and 38 trend wells during resampling, were analyzed for low-level concentrations of 1,2,3-TCP. During initial sampling in 2004-2005, 1,2,3-TCP was detected in one well (KWH-12) in the Southeast San Joaquin Valley study unit (table 7). During resampling in 2007-2008, 1,2,3-TCP was detected in five wells in the Southern Sacramento Valley study unit and in two wells in the Southeast San Joaquin Valley study unit. One of the two Southeast San Joaquin Valley study unit wells in which 1,2,3-TCP was detected during resampling was KWH-12, the same well that had a detection of 1,2,3-TCP during initial sampling.

\section{Inorganic Constituents}

Unlike the organic constituents and the constituents of special interest, most of the inorganic constituents are naturally present in groundwater, although their concentrations may be influenced by human activities. 


\section{Nutrients}

Nutrients (nitrogen and phosphorus) present in groundwater can affect biological activity in aquifers and in surface-water bodies that receive groundwater discharge. Inorganic nitrogen may be present in the form of ammonia, nitrite, or nitrate, depending on the oxidation-reduction state of the groundwater. Analyses for nutrients in GAMA-PBP samples include the determination of these forms of nitrogen, as well as total nitrogen (dissolved) and orthophosphate (the most biologically available form of phosphorus). Less than half (19 out of 55) of the trend wells were sampled for nutrients during initial sampling in 2004-2005 (table 8).

During resampling in 2007-2008, 50 trend wells were sampled for nutrients. Samples from five trend wells (all from the San Diego Drainages study unit) were not analyzed for nutrients during resampling.

All concentrations of ammonia and nitrite measured in the trend wells were less than health-based benchmarks during both sampling periods (table 8). Results for these two nitrogen species were similar between the two sampling periods for the 18 trend wells sampled for both periods; most trend-well results for both periods were non-detections for ammonia and nitrite. In contrast, orthophosphate was at greater concentrations for most (16 of the 18) of these wells during resampling than during initial sampling. No Federal or State drinking-water standard, such as an MCL, exists for phosphorus and phosphorus compounds.

In most cases, sample concentrations of nitrite plus nitrate (as nitrogen) consist nearly entirely of nitrate, so this analysis will hereafter be referred to as nitrate. During resampling in 2007-2008, concentrations of nitrate greater than the MCL-US of 10 milligrams per liter $(\mathrm{mg} / \mathrm{L})$ were detected in four trend wells sampled in the San Fernando-San Gabriel study unit and in one trend well sampled in the Southeast San Joaquin Valley study unit (table 8). Two of the San Fernando-San Gabriel study unit wells (ULASF-09 and ULASG-08) with nitrate (as nitrogen) greater than $10 \mathrm{mg} / \mathrm{L}$ had been sampled for nutrients during initial sampling in 2005. Both wells had similar, but lower nitrate concentrations in 2005 than in 2008. Samples from the other three trend wells with nitrate (as nitrogen) concentrations greater than the MCL-US of $10 \mathrm{mg} / \mathrm{L}$ in 2008 were not analyzed for nutrients in 2005 (table 8).

\section{Major and Minor Ions, TDS, and Trace Elements}

Benchmarks for major and minor ions, total dissolved solids (TDS), and trace elements in water used for public supply are based on human-health concerns, aesthetic properties (such as taste, color, and odor), or technical properties (such as scaling and staining). The $\mathrm{CDPH}$ has established non-health-based secondary benchmarks (SMCL-CAs) based on aesthetic and technical properties for iron, manganese, silver, zinc, chloride, sulfate, and TDS. A health-based MCL-CA has been established for fluoride (a minor ion), and 17 of the 24 trace elements analyzed in this study have health-based benchmarks (MCL-US, MCL-CA, NL-US, AL-US, and HAL-US). Samples from 24 trend wells were analyzed for major and minor ions, silica, TDS, and trace elements during the initial sampling period in 2004-2005; samples from 45 trend wells were analyzed for these constituents during resampling in 2007-2008. The concentrations of the major and minor ions, silica, and TDS are given in table 9. The concentrations of the trace elements are given in table 10 .

Chloride concentrations greater than the recommended SMCL-CA benchmark of $250 \mathrm{mg} / \mathrm{L}$ were detected in two trend wells during resampling in 2007-2008; one well each from the Southern Sacramento Valley (YOL-14) and the Monterey Bay and Salinas Valley Basins (MSMB-04) study units (table 9). Chloride in the Southern Sacramento Valley trend well was at a concentration similar to what it was during initial sampling in 2005. The chloride concentration in the Monterey Bay and Salinas Valley trend well was greater than the SMCL-CA in 2008, and less than the SMCL-CA in 2005. The chloride concentration in another trend well (NSFVP-36) from the North San Francisco Bay study unit was slightly greater than the benchmark in 2005 (rounded to $250 \mathrm{mg} / \mathrm{L}$ in table 9), but the sample from this well in 2007 was not analyzed for major ions.

Sulfate concentrations greater than the recommended SMCL-CA benchmark of $250 \mathrm{mg} / \mathrm{L}$ were detected in only one trend well in the Northern San Joaquin Basin study unit (TRCY-03) during resampling in 2008 (table 9). The sulfate concentration in this well during initial sampling in 2005 was just under the recommended SMCL-CA.

Fluoride is the only minor ion with an MCL-CA, and no trend wells had concentrations greater than the MCL-CA during either sampling period.

TDS concentrations greater than the recommended SMCL-CA benchmark of $500 \mathrm{mg} / \mathrm{L}$ were detected in samples from 10 trend wells during resampling in 2007-2008; one of these wells (MSPR-09 in the Monterey Bay and Salinas Valley Basins study unit) had a TDS concentration greater than the upper SMCL-CA benchmark of 1,000 mg/L (table 9). In 4 of these 10 trend wells with TDS concentrations greater than the recommended SMCL-CA benchmark during 2007-2008, TDS concentrations were also greater than $500 \mathrm{mg} / \mathrm{L}$ during initial sampling. Samples from the other six trend wells were not analyzed for TDS during the initial sampling. In addition to the four trend wells with TDS concentrations greater than the benchmark during both sampling periods, two wells sampled only during the initial sampling period for TDS had concentrations greater than that benchmark.

Seventeen of the 24 trace elements analyzed in this study have health-based benchmarks (MCL-US, MCL-CA, NL-US, AL-US, and HAL-US). Concentrations of 13 of the 17 trace elements that have health-based benchmarks were less than these health-based benchmarks in samples collected during both sampling periods (table 10). Arsenic, boron, vanadium, and molybdenum were detected in some trend wells at concentrations greater than their health-based benchmarks. 
Arsenic was detected in five trend wells at concentrations greater than its MCL-US of $10 \mu \mathrm{g} / \mathrm{L}$ during resampling in 2008 (table 10). Two of these wells were in the Northern San Joaquin Basin study unit, and the other three were in the Southern Sacramento Valley, the Monterey Bay and Salinas Valley Basins, and the Southeast San Joaquin Valley study units. None of these wells were sampled for trace elements during initial sampling in 2005. Arsenic was detected in one trend well in the North San Francisco Bay study unit (NSFVP-38) at a concentration greater than the MCL-US during initial sampling in 2004; this well was not sampled for trace elements in 2007.

Boron was detected in samples from five trend wells at concentrations greater than its NL-CA of $1,000 \mu \mathrm{g} / \mathrm{L}$ during resampling in 2008 (table 10). Three of these wells were in the Southern Sacramento Valley study unit. The other two wells were in the Northern San Joaquin Basin and Monterey Bay and Salinas Valley Basins study units. Two of the wells in the Southern Sacramento Valley study unit and the well in the Northern San Joaquin Basin study unit with boron concentrations greater than the benchmark in 2008 were also sampled for trace elements in 2005. Boron concentrations in one of the Southern Sacramento Valley trend wells and in the Northern San Joaquin Basin trend well were also greater than the benchmark in 2005. However, the boron concentration in the other Southern Sacramento Valley trend well (YOL-14) in 2005 was substantially lower than its concentration in 2008 and was less than the benchmark. The boron concentration detected in a trend well in the North San Francisco Bay study unit during initial sampling in 2004 (NSFVP-38) was nearly four times the NL-CA; this well was not sampled for trace elements in 2007 (table 10).

Vanadium was detected in two trend wells at concentrations greater than its NL-CA of $50 \mu \mathrm{g} / \mathrm{L}$ during resampling in 2007-2008. One of the wells was in the San Diego Drainages study unit, and the other well was in the Southeast San Joaquin Valley study unit (table 10). Both of these wells were also sampled for trace elements during initial sampling in 2004-2005. The vanadium concentration in the San Diego Drainages trend well in 2004 was nearly identical to its concentration in that well in 2007 and also was greater than the benchmark. The vanadium concentration in the Southeast San Joaquin Valley trend well in 2005 was slightly lower than its concentration in 2008 and just less than the NL-CA.
Molybdenum was detected above its HAL-US in two wells in the Monterey Bay and Salinas Valley Basins study unit during resampling in 2008 (table 10). These two wells were not sampled for trace elements in 2005. Molybdenum was not detected at concentrations above the health-based benchmark in any trend wells that were sampled for trace elements during initial sampling in 2004-2005.

Four trace elements analyzed in this study-iron, manganese, silver, and zinc - have benchmarks that are nonhealth-based SMCLs established for aesthetic concerns (taste and odor). Samples from six wells had iron concentrations above the SMCL, and samples from ten trend wells had manganese concentrations above the SMCL, during one or both sampling periods (table 10). Iron and manganese are trace elements whose concentrations are affected by the oxidationreduction state of the groundwater. Precipitation of minerals containing iron or manganese may cause orange, brown, or black staining of surfaces. Relatively high concentrations of manganese often co-occurred with relatively high concentrations of iron. In every case in which the samples from a well had concentrations of iron or manganese above the SMCL and were analyzed for trace elements during both sampling periods, the concentrations of these constituents were above the SMCL for both periods. Silver was not detected in the trend wells during either sampling period, and all detections of zinc were below the SMCL for both sampling periods.

Arsenic and iron can occur as different species depending on the oxidation-reduction state of the groundwater. The oxidized and reduced species have different solubilities in groundwater, and the relative proportions of the oxidized and reduced species of each element can be used in the interpretation of the oxidation-reduction conditions of the aquifer. Concentrations of total dissolved arsenic and iron and the concentrations of the reduced species of each element were analyzed by the USGS National Research Program (NRP) Trace Metal Laboratory (TML), Boulder, Colorado, for samples from 21 trend wells during the initial sampling in 2004-2005 and samples from 14 trend wells during the resampling in 2007-2008 (table 11). The concentrations of the oxidized species can be calculated by difference.

The proportions of reduced to oxidized species between the sampling periods changed little for six of the nine trend wells that were resampled. However, dissolved arsenic in three wells in the North San Francisco Bay study unit (NSFVOL-14, NSFVP-38, NSFWGFP-01) went from being predominantly in the oxidized form, $\mathrm{As}(\mathrm{V})$, in 2004 to mostly in the reduced form, As(III), in 2007. 


\section{Isotopic Tracers}

The isotopic ratios of oxygen and hydrogen in water and tritium and carbon-14 activities may be used as tracers of hydrologic processes. The isotopic ratios of hydrogen and oxygen in water $\left(\delta^{2} \mathrm{H}\right.$ and $\left.\delta^{18} \mathrm{O}\right)$ aid in interpretation of the sources of groundwater recharge. These stable isotopic ratios reflect the altitude, latitude, and temperature of precipitation and also the extent of evaporation of the water in surfacewater bodies or soils prior to infiltration into the aquifer. The isotopic ratios of hydrogen and oxygen in water were measured for all trend wells during both sampling periods (table 12). These ratios appeared to change little between the sampling periods with one exception; a San Diego Drainages study unit well (SDTEM-04) had a substantially more negative isotopic ratio in 2007 than in 2004.

Tritium and carbon-14 activities also provide information about the age (time since recharge) of the groundwater. Tritium is a short-lived radioactive isotope of hydrogen that is incorporated into the water molecule. Low levels of tritium are continuously produced by interaction of cosmic radiation with the Earth's atmosphere, and a large amount of tritium was produced as a result of atmospheric testing of nuclear weapons between 1952 and 1963. Thus, concentrations of tritium above background generally indicate the presence of water recharged since the early 1950s. All samples from trend wells were analyzed for tritium except for five samples from the Southeast San Joaquin Valley study unit during initial sampling in 2005 (tables 2, 12). Tritium analyses were performed by the USGS Stable Isotope and Tritium Laboratory, Menlo Park, California. The method of reporting uncertainties in tritium activities by this laboratory changed between the initial sampling in 2004-2005 and the resampling in 2007-2008. Therefore, most resampling results for tritium in table 12 are reported as the measured value in picocuries per liter plus or minus ( \pm ) the combined standard uncertainty. Results for initial sampling, as well as the earlier resampling results, do not include the combined standard uncertainty.

Of the isotopic tracers analyzed for this study, tritium is the only one with a health-based benchmark - an MCL-CA of 20,000 picocuries per liter (pCi/L). All tritium activities in samples from trend wells during both sampling periods were less than one one-thousandth of this benchmark (table 12). The differences in tritium activities between sampling periods were small for the trend wells.
Carbon-14 is a radioactive isotope of carbon. Low levels of carbon-14 are continuously produced by interaction of cosmic radiation with the Earth's atmosphere and are incorporated into atmospheric carbon dioxide. The carbon dioxide dissolves in precipitation, surface water, and groundwater exposed to the atmosphere, thereby entering the hydrologic cycle. Because carbon-14 decays with a half-life of approximately 5,700 years, low activities of carbon- 14 relative to modern values generally indicate presence of groundwater that is several thousand years old. Seventeen trend wells were sampled for carbon-14 during initial sampling in 2004-2005. Twenty-nine trend wells were sampled for carbon-14 during resampling in 2007-2008 (tables 2, 12). In most cases, if a well was sampled for carbon-14 during initial sampling, it was not resampled for carbon-14. Nine trend wells were sampled for carbon-14 during both sampling periods. In eight of these nine wells, the percentages of modern carbon (pmc) were similar for the two sampling periods. However, groundwater from one well in the Monterey Bay and Salinas Valley Basins study unit (MSMB-04) had results of 5.7 pmc in 2005 and $83 \mathrm{pmc}$ in 2008.

\section{Future Work}

Reports similar to this one are planned to present data from initial sampling and resampling for trend evaluations of the remaining 28 GAMA-PBP study units not included here. Reports subsequent to these trends data reports will be focused on assessment of the data presented in this report and the other trend data reports by using a variety of statistical, qualitative, and quantitative approaches to evaluate the natural and human factors affecting temporal changes in groundwater quality. Water-quality data contained in the CDPH and USGS databases, and water-quality data available from other State and local water agencies will be compiled, evaluated, and used in combination with the data that is presented in the trends data reports. The results of these future efforts will appear in one or more subsequent reports. 


\section{Summary}

Data from 55 wells sampled during two sampling periods (2004-2005 and 2007-2008) in seven study units are presented in this report as part of an assessment of temporal trends in groundwater quality being conducted by the California State Water Resources Control Board (SWRCB) Groundwater Ambient Monitoring and Assessment (GAMA) Program's Priority Basin Project (PBP). The GAMA Program was created to provide a comprehensive baseline of groundwater quality in the State, and to evaluate changes over time (trends) in this groundwater quality. The GAMA-PBP was created as a result of the Groundwater Quality Monitoring Act of 2001 (Sections 10780-10782.3 of the California Water Code, Assembly Bill 599) to assess and monitor the quality of groundwater. The GAMA-PBP is being conducted by the USGS in cooperation with the SWRCB and Lawrence Livermore National Laboratory (LLNL).

The GAMA-PBP was designed to provide a spatially unbiased assessment of untreated-groundwater quality within the primary aquifer systems and to facilitate statistically consistent comparisons of untreated-groundwater quality throughout California. The primary aquifer systems are defined as parts of aquifers corresponding to the perforation intervals of wells listed in the California Department of Public Health (CDPH) database for each study unit. The quality of groundwater in shallow or deep water-bearing zones may differ from that in the primary aquifer systems; shallow groundwater may be more vulnerable to surficial contamination.

This study did not attempt to evaluate the quality of water delivered to consumers; after withdrawal from the ground, water typically is treated, disinfected, and blended with other waters to maintain acceptable water quality. The benchmarks used in this report apply to treated water that is served to the consumer, not to untreated groundwater. However, to provide some context for the results, concentrations of constituents measured in these groundwater samples were compared to benchmarks established by the U.S. Environmental Protection Agency (USEPA) and CDPH.

During the initial sampling period (2004-2005) for the 7 study units discussed in this report, 462 wells were selected using a randomized grid approach to achieve a statistically unbiased representation of groundwater used for public drinking-water supplies (grid wells). Fifty-five of these grid wells (approximately 10 percent in each of the 7 study units) were resampled for trends during 2007-2008. The study units, the number of grid wells during initial sampling, and the number of these wells that were resampled for trends in each study unit were as follows: the San Diego Drainages (51 grid wells, 7 trend wells), North San Francisco Bay (84, 10), Northern San Joaquin Basin (51, 5), Southern Sacramento Valley $(67,7)$, San Fernando-San Gabriel $(35,6)$, Monterey Bay and Salinas Valley Basins $(91,11)$, and Southeast San Joaquin Valley $(83,9)$.
Groundwater samples were analyzed for water-quality indicators, organic constituents, special-interest constituents, inorganic constituents, and isotopic tracers. Seventeen of the constituents were analyzed by using two different methods of analysis, resulting in up to 288 measurements that could have been made on each sample. This report describes the sampling, analytical, and quality-assurance methods used in the study and presents the results of the chemical analyses of the 288 measurements from initial sampling and resampling for trends in the primary aquifer systems.

Quality-control samples (blanks, replicates, and matrix spikes) were collected at more than 20 percent of the wells during resampling for trends, and the results for these samples were used to evaluate the quality of the data for the groundwater samples. Blanks rarely contained detectable concentrations of any constituent. Replicate samples generally were within the acceptable limits of variability, and matrixspike recoveries were largely within the acceptable range.

Twenty-five volatile organic compounds (VOCs) and 16 pesticide compounds were detected in trend wells. All pesticide detections and nearly all VOC detections were at concentrations less than health-based benchmarks. The VOCs detected at concentrations greater than health-based benchmarks were 1,2-dibromo-3-chloropropane (DBCP), methyl tert-butyl ether (MTBE), tetrachloroethene (PCE), and trichloroethene (TCE). The VOCs detected in more than 10 percent of the trend wells during both sampling periods were chloroform, bromodichloromethane, cis1,2-dichloroethene, PCE, and TCE. In addition, carbon tetrachloride was detected in more than 10 percent of the trend wells during the initial sampling period. The pesticide compounds that were detected in more than 10 percent of the trend wells during both sampling periods were atrazine, deethylatrazine, and simazine.

Perchlorate, $N$-nitrosodimethylamine (NDMA), and 1,2,3-trichloropropane (1,2,3-TCP) are constituents of special interest in California. Perchlorate was detected at concentrations greater than health-based benchmarks in two trend wells in the San Fernando-San Gabriel study unit during the resampling period in 2008. NDMA was not detected during either sampling period. 1,2,3-TCP was detected more frequently during resampling; however, more samples were submitted for low-level analysis of 1,2,3-TCP during resampling than during initial sampling.

Most inorganic constituents are naturally present in groundwater but at concentrations less than water-quality benchmarks. Nitrate concentrations were greater than the health-based benchmark in samples from a few trend wells in the San Fernando-San Gabriel and Southeast San Joaquin Valley study units, and these concentrations generally were similar between sampling periods for wells that were sampled for nutrients both times. Arsenic, boron, and vanadium were detected in some trend wells at concentrations greater than their health-based benchmarks during both sampling periods. Similarly, total dissolved solids, iron, and manganese were detected at concentrations greater than secondary maximum 
contaminant levels (SMCL-CAs) (non-health-based benchmarks set for aesthetic concerns) in samples from a few wells during both sampling periods. Subsequent reports will present analyses of the data presented in this report using a variety of statistical, qualitative, and quantitative approaches to assess the natural and human factors affecting changes in groundwater quality.

\section{Acknowledgments}

The authors thank the following cooperators for their support: the California State Water Resources Control Board, California Department of Public Health, California Department of Water Resources, and Lawrence Livermore National Laboratory. In addition, we especially thank the well owners and water purveyors for allowing the U.S. Geological Survey to collect samples from their wells. Funding for this work was provided by State of California bonds authorized by Proposition 50 and administered by the California State Water Resources Control Board.

\section{References Cited}

American Public Health Association, 1998, Standard methods for the examination of water and wastewater (20th ed.): Washington, D.C., American Public Health Association, American Water Works Association, and Water Environment Federation, p. 3-37-3-43.

Andreu, V., and Pico, Y., 2004, Determination of pesticides and their degradation products in soil - Critical review and comparison of methods: Trends in Analytical Chemistry, v. 23, no. 10-11, p. 772-789, accessed December 11, 2011, at http://www.uv.es/ pico/papers/35.pdf.

Belitz, Kenneth, Dubrovsky, N.M., Burow, K.R., Jurgens, Bryant, and Johnson, Tyler, 2003, Framework for a ground-water quality monitoring and assessment program for California: U.S. Geological Survey Water-Resources Investigations Report 03-4166, 78 p.

Bennett, G.L., V, Belitz, Kenneth, and Milby Dawson, B.J., 2006, California GAMA Program - Ground-water quality data in the Northern San Joaquin Basin study unit, 2005: U.S. Geological Survey Data Series 196, 122 p.

Bennett, G.L., V, Fram, M.S., and Belitz, Kenneth, 2011, Status of groundwater quality in the Southern, Middle, and Northern Sacramento Valley study units, 2005-08California GAMA Priority Basin Project: U.S. Geological Survey Scientific Investigations Report 2011-5002, 120 p.
Bennett, G.L., V, Fram, M.S., Belitz, Kenneth, and Jurgens, B.C., 2010, Status and understanding of groundwater quality in the northern San Joaquin Basin, 2005-California GAMA Priority Basin Project: U.S. Geological Survey Scientific Investigations Report 2010-5175, 82 p.

Burton, C.A., and Belitz, Kenneth, 2008, Groundwater quality data in the southeast San Joaquin Valley, 20052006-Results from the California GAMA Program: U.S. Geological Survey Data Series 351, 103 p. (Also available at http://pubs.usgs.gov/ds/351/.)

Burton, C.A., Montrella, Joseph, Landon, M.K., and Belitz, Kenneth, 2012, Status and understanding of groundwater quality in two southern San Joaquin Valley study units, 2005-2006-California GAMA Priority Basin Project: U.S. Geological Survey Scientific Investigations Report 2011-5218, 150 p. (Also available at http://pubs. usgs.gov/sir/2011/5218/.)

California Department of Public Health, 2008a, California drinking water-related laws: Drinking water-related regulations (Title 22) (pdf document), accessed July 26, 2012, at http://www.cdph.ca.gov/certlic/drinkingwater/ Pages/Lawbook.aspx.

California Department of Public Health, 2008b, Drinking water notification levels: Notification levels (pdf document), accessed July 26, 2012, at http://www.cdph.ca.gov/certlic/ drinkingwater/Pages/NotificationLevels.aspx.

California Department of Water Resources, 2003, California's groundwater: California Department of Water Resources Bulletin 118, 246 p., accessed July 13, 2012, at http://www. water.ca.gov/groundwater/bulletin118/update2003.cfm.

California Department of Water Resources, 2004a, California's groundwater: Individual basin descriptions, Temecula Valley Groundwater Basin: California Department of Water Resources Bulletin 118, accessed August 7, 2012, at http://www.water.ca.gov/pubs/groundwater/bulletin_118/ basindescriptions/9-5.pdf.

California Department of Water Resources, 2004b, California's groundwater: Individual basin descriptions, Warner Valley Groundwater Basin: California Department of Water Resources Bulletin 118, accessed August 7, 2012, at http://www.water.ca.gov/pubs/groundwater/bulletin_118/ basindescriptions/9-8.pdf.

California Department of Water Resources, 2004c, California's groundwater: Individual basin descriptions, Potrero Valley Groundwater Basin: California Department of Water Resources Bulletin 118, accessed August 7, 2012, at http://www.water.ca.gov/pubs/groundwater/bulletin_118/ basindescriptions/9-29.pdf. 
California Department of Water Resources, 2004d, California's groundwater: Individual basin descriptions, San Luis Rey Valley Groundwater Basin: California Department of Water Resources Bulletin 118, accessed August 7, 2012, at http://www.water.ca.gov/pubs/groundwater/bulletin_118/ basindescriptions/9-7.pdf.

California Department of Water Resources, 2004e, California's groundwater: Individual basin descriptions, Sacramento Valley Groundwater Basin, South American subbasin: California Department of Water Resources Bulletin 118, accessed August 7, 2012, at http://www.water.ca.gov/pubs/ groundwater/bulletin_118/basindescriptions/5-21.65.pdf.

California Department of Water Resources, 2004f, California's groundwater: Individual basin descriptions, Sacramento Valley Groundwater Basin, Solano subbasin: California Department of Water Resources Bulletin 118, accessed August 7, 2012, at http://www.water.ca.gov/pubs/ groundwater/bulletin_118/basindescriptions/5-21.66.pdf.

California Department of Water Resources, 2004g, California's groundwater: Individual basin descriptions, Sacramento Valley Groundwater Basin, Yolo subbasin: California Department of Water Resources Bulletin 118, accessed August 7, 2012, at http://www.water.ca.gov/pubs/ groundwater/bulletin_118/basindescriptions/5-21.67.pdf.

California Department of Water Resources, 2004h, California's groundwater: Individual basin descriptions, San Fernando Valley Groundwater Basin: California Department of Water Resources Bulletin 118, accessed August 7, 2012, at http://www.water.ca.gov/pubs/groundwater/bulletin_118/ basindescriptions/4-12.pdf.

California Department of Water Resources, 2004i, California's groundwater: Individual basin descriptions, San Gabriel Valley Groundwater Basin: California Department of Water Resources Bulletin 118, accessed August 7, 2012, at http://www.water.ca.gov/pubs/groundwater/bulletin_118/ basindescriptions/4-13.pdf.

California Department of Water Resources, 2004j, California's groundwater: Individual basin descriptions, Raymond Groundwater Basin: California Department of Water Resources Bulletin 118, accessed August 7, 2012, at http://www.water.ca.gov/pubs/groundwater/bulletin_118/ basindescriptions/4-23.pdf.

California Department of Water Resources, 2004k, California's groundwater: Individual basin descriptions, Felton Area Groundwater Basin: California Department of Water Resources Bulletin 118, accessed August 7, 2012, at http://www.water.ca.gov/pubs/groundwater/bulletin_118/ basindescriptions/3-50.pdf.
California Department of Water Resources, 20041, California's groundwater: Individual basin descriptions, Santa Cruz Purisima Formation Highlands Groundwater Basin: California Department of Water Resources Bulletin 118, accessed August 7, 2012, at http://www.water.ca.gov/pubs/ groundwater/bulletin_118/basindescriptions/3-21.pdf.

California Department of Water Resources, 2004m, California's groundwater: Individual basin descriptions, West Santa Cruz Terrace Groundwater Basin: California Department of Water Resources Bulletin 118, accessed August 7, 2012, at http://www.water.ca.gov/pubs/ groundwater/bulletin_118/basindescriptions/3-26.pdf.

California Department of Water Resources, 2004n, California's groundwater: Individual basin descriptions, Soquel Valley Groundwater Basin: California Department of Water Resources Bulletin 118, accessed August 7, 2012, at http://www.water.ca.gov/pubs/groundwater/bulletin_118/ basindescriptions/3-1.pdf.

California Department of Water Resources, 2004o, California's groundwater: Individual basin descriptions, Carmel Valley Groundwater Basin: California Department of Water Resources Bulletin 118, accessed August 7, 2012, at http://www.water.ca.gov/pubs/groundwater/bulletin_118/ basindescriptions/3-7.pdf.

California Department of Water Resources, 2004p, California's groundwater: Individual basin descriptions, Salinas Valley Groundwater Basin, Corral de Tierra Area subbasin: California Department of Water Resources Bulletin 118, accessed August 7, 2012, at http:// www.water.ca.gov/pubs/groundwater/bulletin_118/ basindescriptions/3-4.10.pdf.

California Department of Water Resources, 2004q, California's groundwater: Individual basin descriptions, Salinas Valley Groundwater Basin, Langley Area subbasin: California Department of Water Resources Bulletin 118, accessed August 7, 2012, at http://www.water.ca.gov/pubs/ groundwater/bulletin_118/basindescriptions/3-4.09.pdf.

California Department of Water Resources, 2004r, California's groundwater: Individual basin descriptions, Salinas Valley Groundwater Basin, Seaside Area subbasin: California Department of Water Resources Bulletin 118, accessed August 7, 2012, at http://www.water.ca.gov/pubs/ groundwater/bulletin_118/basindescriptions/3-4.08.pdf.

California Department of Water Resources, 2004s, California's groundwater: Individual basin descriptions, Salinas Valley Groundwater Basin, Eastside Aquifer subbasin: California Department of Water Resources Bulletin 118, accessed August 7, 2012, at http://www.water.ca.gov/pubs/ groundwater/bulletin_118/basindescriptions/3-4.02.pdf. 
California Department of Water Resources, 2004t, California's groundwater: Individual basin descriptions, Salinas Valley Groundwater Basin, 180/400-Foot Aquifer subbasin: California Department of Water Resources Bulletin 118, accessed August 7, 2012, at http://www.water.ca.gov/pubs/ groundwater/bulletin_118/basindescriptions/3-4.01.pdf.

California Department of Water Resources, 2004u, California's groundwater: Individual basin descriptions, Salinas Valley Groundwater Basin, Upper Valley Aquifer subbasin: California Department of Water Resources Bulletin 118, accessed August 7, 2012, at http:// www.water.ca.gov/pubs/groundwater/bulletin_118/ basindescriptions/3-4.05.pdf.

California Department of Water Resources, 2004v, California's groundwater: Individual basin descriptions, Salinas Valley Groundwater Basin, Forebay Aquifer subbasin: California Department of Water Resources Bulletin 118, accessed August 7, 2012, at http://www.water.ca.gov/pubs/ groundwater/bulletin_118/basindescriptions/3-4.04.pdf.

California Department of Water Resources, 2004w, California's groundwater: Individual basin descriptions, Salinas Valley Groundwater Basin, Paso Robles Area subbasin: California Department of Water Resources Bulletin 118, accessed December 19, 2008, at http:// www.water.ca.gov/pubs/groundwater/bulletin_118/ basindescriptions/3-4.06.pdf.

California Department of Water Resources, 2006a, California’s groundwater: Individual basin descriptions, San Joaquin Valley Groundwater Basin, Eastern San Joaquin subbasin: California Department of Water Resources Bulletin 118, accessed August 7, 2012, at http://www.water.ca.gov/pubs/ groundwater/bulletin_118/basindescriptions/5-22.01.pdf.

California Department of Water Resources, 2006b, California's groundwater: Individual basin descriptions, San Joaquin Valley Groundwater Basin, Tracy subbasin: California Department of Water Resources Bulletin 118, accessed August 7, 2012, at http://www.water.ca.gov/pubs/ groundwater/bulletin_118/basindescriptions/5-22.15.pdf.

California Department of Water Resources, 2006c, California's groundwater: Individual basin descriptions, San Joaquin Valley Groundwater Basin, Cosumnes subbasin: California Department of Water Resources Bulletin 118, accessed August 7, 2012, at http://www.water.ca.gov/pubs/ groundwater/bulletin_118/basindescriptions/5-22.16.pdf.

California Department of Water Resources, 2006d, California's groundwater: Individual basin descriptions, Sacramento Valley Groundwater Basin, North American subbasin: California Department of Water Resources Bulletin 118, accessed August 7, 2012, at http:// www.water.ca.gov/pubs/groundwater/bulletin_118/ basindescriptions/5-21.64.pdf.
California Department of Water Resources, 2006e, California's groundwater: Individual basin descriptions, Scotts Valley Groundwater Basin: California Department of Water Resources Bulletin 118, accessed August 7, 2012, at http://www.water.ca.gov/pubs/groundwater/bulletin_118/ basindescriptions/3-27.pdf.

California Department of Water Resources, 2006f, California's groundwater: Individual basin descriptions, Pajaro Valley Groundwater Basin: California Department of Water Resources Bulletin 118, accessed August 7, 2012, at http://www.water.ca.gov/pubs/groundwater/bulletin_118/ basindescriptions/3-2.pdf.

California Department of Water Resources, 2006g, California's groundwater: Individual basin descriptions, San Joaquin Valley Groundwater Basin, Kings subbasin: California Department of Water Resources Bulletin 118, accessed August 7, 2012, at http:/www.water.ca.gov/pubs/ groundwater/bulletin_118/basindescriptions/5-22.08.pdf.

California Department of Water Resources, 2006h, California's groundwater: Individual basin descriptions, San Joaquin Valley Groundwater Basin, Kaweah subbasin: California Department of Water Resources Bulletin 118, accessed August 7, 2012, at http:/www.water.ca.gov/pubs/ groundwater/bulletin_118/basindescriptions/5-22.11.pdf.

California Department of Water Resources, 2006i, California's groundwater: Individual basin descriptions, San Joaquin Valley Groundwater Basin, Tule subbasin: California Department of Water Resources Bulletin 118, accessed August 7, 2012, at http://www.water.ca.gov/pubs/ groundwater/bulletin_118/basindescriptions/5-22.13.pdf.

California Department of Water Resources, 2006j, California's groundwater: Individual basin descriptions, San Joaquin Valley Groundwater Basin, Tulare Lake subbasin: California Department of Water Resources Bulletin 118, accessed August 7, 2012, at http:/www.water.ca.gov/pubs/ groundwater/bulletin_118/basindescriptions/5-22.12.pdf.

California State Water Resources Control Board, 2003, Report to the Governor and Legislature, A comprehensive groundwater quality monitoring program for California: Assembly Bill 599 March 2003, 100 p., accessed July 13, 2012, at http://www.waterboards.ca.gov/gama/docs/final_ ab_599_rpt_to_legis_7_31_03.pdf.

California State Water Resources Control Board, 2009, Geotracker GAMA: State Water Resources Control Board database, accessed July 30, 2012, at https://geotracker. waterboards.ca.gov/gama/.

California State Water Resources Control Board, 2012, GAMA - Groundwater Ambient Monitoring and Assessment Program: State Water Resources Control Board website, accessed July 13, 2012, at http://www.waterboards. ca.gov/water_issues/programs/gama/. 
Childress, C.J.O., Foreman, W.T., Connor, B.F., and Maloney, T.J., 1999, New reporting procedures based on long-term method detection levels and some considerations for interpretations of water-quality data provided by the U.S. Geological Survey National Water Quality Laboratory: U.S. Geological Survey Open-File Report 99-193, 19 p.

Connor, B.F., Rose, D.L., Noriega, M.C., Murtagh, L.K., and Abney, S.R., 1998, Methods of analysis by the U.S. Geological Survey National Water Quality Laboratory-Determination of 86 volatile organic compounds in water by gas chromatography/mass spectrometry, including detections less than reporting limits: U.S. Geological Survey Open-File Report 97-829, 78 p.

Coplen, T.B., 1994, Reporting of stable hydrogen, carbon, and oxygen isotopic abundances: Pure and Applied Chemistry, v. 66 , p. $273-276$.

Coplen, T.B., Hopple, J.A., Bohlke, J.K., Peiser, H.S., Rieder, S.E., Krouse, H.R., Rosman, K.J.R., Ding, T., Vocke, R.D., Jr., Revesz, K.M., Lamberty, A., Taylor, P., and DeBierve, P., 2002, Compilation of minimum and maximum isotope ratios of selected elements in naturally occurring terrestrial materials and reagents: U.S. Geological Survey Water-Resources Investigations Report 01-4222, $98 \mathrm{p}$.

Coplen, T.B., Wildman, J.D., and Chen, J., 1991, Improvements in the gaseous hydrogen-water equilibrium technique for hydrogen isotope analysis: Analytical Chemistry, v. 63, p. 910-912.

Dawson, B.J., Bennett, G.L., V, and Belitz, Kenneth, 2008, California GAMA Program: Ground-water quality data in the Southern Sacramento Valley study unit, California, 2005: U.S. Geological Survey Data Series 285, 93 p. (Also available at http://pubs.usgs.gov/ds/285.)

Donahue, D.J., Linick, T.W., and Jull, A.J.T., 1990, Isotoperatio and background corrections for accelerator mass spectrometry radiocarbon measurements: Radiocarbon, v. 32, book 2, p. 135-142.

Epstein, S., and Mayeda, T.K., 1953, Variation of O-18 content of water from natural sources: Geochimica et Cosmochimica Acta, v. 4, p. 213-224.

Faires, L.M., 1993, Methods of analysis by the U.S. Geological Survey National Water Quality Laboratory-Determination of metals in water by inductively coupled plasma-mass spectrometry: U.S. Geological Survey Open-File Report 92-634, 28 p.

Fishman, M.J., 1993, Methods of analysis by the U.S. Geological Survey National Water Quality Laboratory-Determination of inorganic and organic constituents in water and fluvial sediments: U.S. Geological Survey Open-File Report 93-125, 217 p.
Fishman, M.J., and Friedman, L.C., 1989, Methods for determination of inorganic substances in water and fluvial sediments: U.S. Geological Survey Techniques of WaterResources Investigations, book 5, chap. A1, 545 p.

Fram, M.S., Olsen, L.D., and Belitz, Kenneth, 2012, Evaluation of volatile organic compound (VOC) blank data and application of study reporting levels to groundwater data collected for the California GAMA Priority Basin Project, May 2004 through September 2010: U.S. Geological Survey Scientific Investigations Report 2012-5139, 94 p.

Furlong, E.T., Anderson, B.D., Werner, S.L., Soliven, P.P., Coffey, L.J., and Burkhardt, M.R., 2001, Methods of analysis by the U.S. Geological Survey National Water Quality Laboratory-Determination of pesticides in water by graphitized carbon-based solid-phase extraction and high-performance liquid chromatography/mass spectrometry: U.S. Geological Survey Water-Resources Investigations Report 01-4134, $73 \mathrm{p}$.

Gagnon, A.R., and Jones, G.A., 1993, AMS-graphite target production methods at the Woods Hole Oceanographic Institution during 1986-1991: Radiocarbon, v. 35, book 2, p. 301-310.

Garbarino, J.R., 1999, Methods of analysis by the U.S. Geological Survey National Water Quality Laboratory-Determination of dissolved arsenic, boron, lithium, selenium, strontium, thallium, and vanadium using inductively coupled plasma-mass spectrometry: U.S. Geological Survey Open-File Report 99-093, 31 p.

Garbarino, J.R., Kanagy, J.R., and Cree, M.E., 2006, Determination of elements in natural-water, biota, sediment, and soil samples using collision/reaction cell inductively coupled plasma-mass spectrometry: U.S. Geological Survey Techniques and Methods, book 5, chap. B1, 88 p.

Gilliom, R.J., Barbash, J.E., Crawford, C.G., Hamilton, P.A., Martin, J.D., Nakagaki, N., Nowell, L.H., Scott, J.C., Stackelberg, P.E., Thelin, G.P., and Wolock, D.M., 2006, The quality of our nation's waters-Pesticides in the nation's streams and ground water, 1992-2001: U.S. Geological Survey Circular 1291, 172 p. (Also available at http://pubs.usgs.gov/circ/2005/1291/pdf/ circ1291_front.pdf.)

Hautman, D.P., Munch, D.J., Eaton, A.D., and Haghani, A.W., 1999, Method 314.0, revision 1.0-Determination of perchlorate in drinking water using ion chromatography: U.S. Environmental Protection Agency, accessed June 22, 2004, at http://www.epa.gov/safewater/methods/pdfs/ met314.pdf.

Hem, J.D., 1985, Study and interpretation of the chemical characteristics of natural water: U.S. Geological Survey Water-Supply Paper 2254, 263 p., 3 pls. 
Hoaglin, D.C., 1983, Letter values-A set of selected order statistics, in Hoaglin, D.C., Mosteller, F., and Tukey, J.W., eds., Understanding robust and exploratory data analysis: New York, John Wiley \& Sons, p. 33-54.

Kenny, J.F., Barber, N.L., Hutson, S.S., Linsey, K.S., Lovelace, J.K., and Maupin, M.A., 2009, Estimated use of water in the United States in 2005: U.S. Geological Survey Circular 1344, 52 p. (Also available at http://pubs.usgs.gov/ circ/1344/.)

Koterba, M.T., Wilde, F.D., and Lapham, W.W., 1995, Ground-water data-collection protocols and procedures for the National Water-Quality Assessment ProgramCollection and documentation of water-quality samples and related data: U.S. Geological Survey Open-File Report 95-399, 113 p. (Also available at http://pubs.usgs. gov/of/1995/ofr-95-399.)

Kulongoski, J.T., and Belitz, Kenneth, 2004, Groundwater ambient monitoring and assessment program: U.S. Geological Survey Fact Sheet 2004-3088, 2 p. (Also available at http://pubs.usgs.gov/fs/2004/3088/.)

Kulongoski, J.T., and Belitz, Kenneth, 2007, Ground-water quality data in the Monterey Bay and Salinas Valley Basins, California, 2005-Results from the California GAMA Program: U.S. Geological Survey Data Series 258, 84 p. (Also available at http://pubs.usgs.gov/ds/2007/258.)

Kulongoski, J.T., and Belitz, Kenneth, 2011, Status and understanding of groundwater quality in the Monterey Bay and Salinas Valley Basins, 2005-California GAMA Priority Basin Project: U.S. Geological Survey Scientific Investigations Report 2011-5058, 84 p. (Also available at http://pubs.usgs.gov/sir/2011/5058/.)

Kulongoski, J.T., Belitz, Kenneth, and Dawson, B.J., 2006, Ground-water quality data in the North San Francisco Bay hydrogeologic provinces, California, 2004-Results from the California Ground-Water Ambient Monitoring and Assessment (GAMA) Program: U.S. Geological Survey Data Series 167, 100 p. (Also available at http://pubs.usgs. gov/ds/ds 167.)

Kulongoski, J.T., Belitz, Kenneth, Landon, M.K., and Farrar, Christopher, 2010, Status and understanding of groundwater quality in the North San Francisco Bay groundwater basins, 2004 - California GAMA Priority Basin Project: U.S. Geological Survey Scientific Investigations Report 2010-5089, 88 p. (Also available at http://pubs.usgs.gov/sir/2010/5089/.)

Land, Michael, and Belitz, Kenneth, 2008, Ground-water quality data in the San Fernando-San Gabriel study unit, 2005-Results from the California GAMA Program: U.S. Geological Survey Data Series 356, 84 p. (Also available at http://pubs.usgs.gov/ds/356/.)
Land, Michael, Kulongoski, J.T., and Belitz, Kenneth, 2012, Status of groundwater quality in the San Fernando-San Gabriel study unit, 2005-California GAMA Priority Basin Project: U.S. Geological Survey Scientific Investigations Report 2011-5206, 66 p. (Also available at http://pubs.usgs. gov/sir/2011/5206/.)

Landon, M.K., Belitz, Kenneth, Jurgens, B.C., Kulongoski, J.T., and Johnson, T.D., 2010, Status and understanding of groundwater quality in the CentralEastside San Joaquin Basin, 2006-California GAMA Priority Basin Project: U.S. Geological Survey Scientific Investigations Report 2009-5266, 97 p. (Also available at http://pubs.usgs.gov/sir/2009/5266/.)

Lane, S.L., Flanagan, Sarah, and Wilde, F.D., 2003, Selection of equipment for water sampling (ver. 2.0): U.S. Geological Survey Techniques of Water-Resources Investigations, book 9, chap. A2, accessed June 28, 2007, at http://pubs. water.usgs.gov/twri9A2/.

Lewis, M.E., 2006, Dissolved oxygen (ver. 2.1): U.S. Geological Survey Techniques of Water-Resources Investigations, book 9, chap. A6.2, accessed June 28, 2007, at http://pubs.water.usgs.gov/twri9A6.2/.

Lindley, C.E., Stewart, J.T., and Sandstrom, M.W., 1996, Determination of low concentrations of acetochlor in water by automated solid-phase extraction and gas chromatography with mass selective detection: Journal of AOAC International, v. 79, no. 4, p. 962-966.

Madsen, J.E., Sandstrom, M.W., and Zaugg, S.D., 2003, Methods of analysis by the U.S. Geological Survey National Water Quality Laboratory-A method supplement for the determination of fipronil and degradates in water by gas chromatography/mass spectrometry: U.S. Geological Survey Open-File Report 02-462, 11 p.

Maloney, T.J., ed., 2005, Quality management system, U.S. Geological Survey National Water Quality Laboratory: U.S. Geological Survey Open-File Report 2005-1263, accessed April 1, 2007, at http://pubs.usgs.gov/ of/2005/1263/pdf/OFR2005-1263.pdf.

McCleskey, R.B., Nordstrom, D.K., and Ball, J.W., 2003, Metal interferences and their removal prior to the determination of $\mathrm{As}(\mathrm{T})$ and $\mathrm{As}(\mathrm{III})$ in acid mine waters by hydride generation atomic absorption spectrometry: U.S. Geological Survey Water-Resources Investigations Report 03-4117.

McCurdy, D.E., Garbarino, J.R., and Mullin, A.H., 2008, Interpreting and reporting radiological water-quality data: U.S. Geological Survey Techniques and Methods, book 5, chap. B6, 33 p. 
McLain, B., 1993, Methods of analysis by the U.S. Geological Survey National Water Quality Laboratory-Determination of chromium in water by graphite furnace atomic absorption spectrophotometry: U.S. Geological Survey Open-File Report 93-449, 16 p.

McNichol, A.P., Gagnon, A.R., Jones, G.A., and Osborne, E.A., 1992, Illumination of a black box-Analysis of gas composition during graphite target preparation, in Long, A., and Kra, R.S., eds., Proceedings of the 14th International ${ }^{14} \mathrm{C}$ Conference: Radiocarbon, v. 34, book 3, p. 321-329.

McNichol, A.P., Jones, G.A., Hutton, D.L., and Gagnon, A.R., 1994, The rapid preparation of seawater $\sum \mathrm{CO}_{2}$ for radiocarbon analysis at the National Ocean Sciences AMS Facility: Radiocarbon, v. 36, book 2, p. 237-246.

Okamoto, H.S., Steeber, W.R., Remoy, R., Hill, P., and Perera, S.K., eds., 2002, Determination of 1,2,3-trichloropropane in drinking water by purge and trap gas chromatography/mass spectrometry (February 2002): California Department of Health Services, Division of Drinking Water and Environmental Management, Sanitation and Radiation Laboratories Branch, accessed August 21, 2008, at http://www.cdph.ca.gov/certlic/drinkingwater/ Documents/Drinkingwaterlabs/TCPbyPT-GCMS.pdf.

Olsen, L.D., Fram, M.S., and Belitz, Kenneth, 2010, Review of trace-element field-blank data collected for the California Groundwater Ambient Monitoring and Assessment (GAMA) Program, May 2004-January 2008: U.S. Geological Survey Scientific Investigations Report 2009-5220, 47 p. (Also available at http://pubs.usgs. gov/sir/2009/5220/.)

Patton, C.J., and Kryskalla, J.R., 2003, Methods of analysis by the U.S. Geological Survey National Water Quality Laboratory-Evaluation of alkaline persulfate digestion as an alternative to Kjeldahl digestion for determination of total and dissolved nitrogen and phosphorous in water: U.S. Geological Survey Water-Resources Investigations Report 03-4174, 33 p.

Pirkey, K.D., and Glodt, S.R., 1998, Quality control at the U.S. Geological Survey National Water Quality Laboratory: U.S. Geological Survey Fact Sheet 026-98, 4 p. (Also available at http://pubs.er.usgs.gov/usgspubs/fs/fs02698.)

Plomley, J.B., Koester, C.J., and March, R.E., 1994, Determination of NDMA in complex environmental matrices by quadrupole ion storage tandem mass spectrometry enhanced by unidirectional ion ejection: Analytical Chemistry, v. 66, no. 24, p. 4437-4443.
Radtke, D.B., Davis, J.V., and Wilde, F.D., 2005, Specific electrical conductance (ver. 1.2): U.S. Geological Survey Techniques of Water-Resources Investigations, book 9 , chap. A6.3, accessed June 28, 2007, at http://pubs.water. usgs.gov/twri9A6.3/.

Sandstrom, M.W., Stroppel, M.E., Foreman, W.T., and Schroeder, M.P., 2001, Methods of analysis by the U.S. Geological Survey National Water Quality Laboratory-Determination of moderate-use pesticides and selected degradates in water by $\mathrm{C}-18$ solid-phase extraction and gas chromatography/mass spectrometry: U.S. Geological Survey Water-Resources Investigations Report 01-4098, 70 p.

Schneider, R.J., Jones, G.A., McNichol, A.P., von Reden, K.F., Elder, K.A., Huang, K., and Kessel, E.D., 1994, Methods for data screening, flagging, and error analysis at the National Ocean Sciences AMS Facility: Nuclear Instruments and Methods in Physics Research, book 92, p. $172-175$.

State of California, 2001a, Assembly Bill No. 599, Chapter 522, accessed July 13, 2012, at http://www.swrcb. ca.gov/gama/docs/ab_599_bill_20011005_chaptered.pdf.

State of California, 2001b, Groundwater Monitoring Act of 2001: California Water Code, part 2.76, Sections 10780 10782.3, accessed July 13, 2012, at http://www.leginfo. ca.gov/cgi-bin/displaycode?section=wat\&group=1000111000\&file $=10780-10782.3$.

Stookey, L.L., 1970, FerroZine-A new spectrophotometric reagent for iron: Analytical Chemistry, v. 42, p. 779-781.

Thatcher, L.L., Janzer, V.J., and Edwards, K.W., 1977, Methods for the determination of radioactive substances in water: U.S. Geological Survey Techniques of WaterResources Investigations, book 5, chap. A5, 95 p.

Timme, P.J., 1995, National Water Quality Laboratory 1995 services catalog: U.S. Geological Survey Open-File Report 95-352, 120 p.

To, T.B., Nordstrom, D.K., Cunningham, K.M., Ball, J.W., and McCleskey, R.B., 1998, New method for the direct determination of dissolved Fe(III) concentration in acid mine waters: Environmental Science \& Technology, v. 33, p. $807-813$.

U.S. Environmental Protection Agency, 1989, Method $1625 \mathrm{C}$ - Semivolatile organic compounds by isotope dilution GSMS: U.S. Environmental Protection Agency, Washington, D.C., 68 p., accessed November 14, 2013, at http:/water.epa.gov/scitech/methods/cwa/bioindicators/ upload/2007_11_06_methods_method_1625c.pdf. 
U.S. Environmental Protection Agency, 1995, Method 524.2, Measurement of purgeable organic compounds in water by capillary column gas chromatography/mass spectrometry: U.S. Environmental Protection Agency EPA/600/R-95-131, accessed November 14, 2013, at http://www.nemi.gov/.

U.S. Environmental Protection Agency, 2002, Guidelines for establishing procedures for the analysis of pollutants: U.S. Code of Federal Regulations, Title 40, 136 p.

U.S. Environmental Protection Agency, 2005, Method 331.0Determination of perchlorate in drinking water by liquid chromatography electrospray ionization mass spectrometry (Revision 1.0, January 2005): Office of Ground Water and Drinking Water, EPA Document \#815-R-05-007, 34 p., accessed August 21, 2008, at http://www.epa.gov/safewater/ methods/pdfs/methods/met331_0.pdf.

U.S. Environmental Protection Agency, 2006, Drinking water health advisories - 2006 Drinking water standards and health advisory tables (pdf document), accessed August 7, 2012, at http://water.epa.gov/action/advisories/drinking/ dwstandards.cfm.

U.S. Environmental Protection Agency, 2009, Drinking water contaminants, accessed July 30, 2012, at http://www.epa. gov/safewater/contaminants/index.html.

U.S. Geological Survey, 2011, What is the Priority Basin Project?, accessed July13, 2012, at http://ca.water.usgs.gov/ gama/.

U.S. Geological Survey, variously dated, National field manual for the collection of water-quality data: U.S. Geological Survey Techniques of Water-Resources Investigations, book 9, chap. A1-A9, accessed July 30, 2012, at http:// water.usgs.gov/owq/FieldManual/.

Vogel, J.S., Nelson, D.E., and Southon, J.R., 1987, ${ }^{14} \mathrm{C}$ background levels in an accelerator mass spectrometry system: Radiocarbon, v. 29, book 3, p. 323-333.

Wilde, F.D., ed., 2004, Cleaning of equipment for water sampling (ver. 2.0): U.S. Geological Survey Techniques of Water-Resources Investigations, book 9, chap. A3, accessed February 21, 2013, at http://water.usgs.gov/owq/ FieldManual/chapter3/Ch3_contents.html.

Wilde, F.D., 2006, Temperature (ver. 2): U.S. Geological Survey Techniques of Water-Resources Investigations, book 9, chap. A6.1, accessed February 21, 2013, at http:// water.usgs.gov/owq/FieldManual/Chapter6/6.1_contents. html.
Wilde, F.D., Busenberg, E., and Radtke, D.B., 2006, pH (ver. 1.3): U.S. Geological Survey Techniques of WaterResources Investigations, book 9, chap. A6.4, accessed February 21, 2013, at http://water.usgs.gov/owq/ FieldManual/Chapter6/6.4_contents.html.

Wilde, F.D., and Radtke, D.B., 2005, General information and guidelines (ver. 1.2): U.S. Geological Survey Techniques of Water-Resources Investigations, book 9, chap. A6.0, accessed February 21, 2013, at http://water.usgs.gov/owq/ FieldManual/Chapter6/6.0_contents.html.

Wilde, F.D., Radtke, D.B., Gibs, J., and Iwatsubo, R.T., 1999, Collection of water samples: U.S. Geological Survey Techniques of Water-Resources Investigations, book 9, chap. A4, accessed February 21, 2013, at http://pubs.water. usgs.gov/twri9A4/.

Wilde, F.D., Radtke, D.B., Gibs, J., and Iwatsubo, R.T., 2004, Processing of water samples: U.S. Geological Survey Techniques of Water-Resources Investigations, book 9, chap. A5, accessed June 28, 2007, at http://pubs.water.usgs. gov/twri9A5/.

Wright, M.T., and Belitz, K., 2011, Status and understanding of groundwater quality in the San Diego Drainages hydrogeologic province, 2004-California GAMA Priority Basin Project: U.S. Geological Survey Scientific Investigations Report 2011-5154, 100 p. (Also available at http://pubs.usgs.gov/sir/2011/5154/.)

Wright, M.T., Belitz, Kenneth, and Burton, C.A., 2005, California GAMA Program - Ground-water quality in the San Diego Drainages hydrogeologic province, California, 2004: U.S. Geological Survey Data Series 129, 91 p. (Also available at http://pubs.usgs.gov/ds/2005/129/.)

Zaugg, S.D., Sandstrom, M.W., Smith, S.G., and Fehlberg, K.M., 1995, Methods of analysis by the U.S. Geological Survey National Water Quality Laboratory-Determination of pesticides in water by $\mathrm{C}-18$ solid-phase extraction and capillary-column gas chromatography/mass spectrometry: U.S. Geological Survey Open-File Report 95-181, 60 p.

Zogorski, J.S., Carter, J.M., Ivahnenko, T., Lapham, W.W., Moran, M.J., Rowe, B.L., Squillace, P.J., and Toccalino, P.L., 2006, Volatile organic compounds in the Nation's ground water and drinking-water supply wells: U.S. Geological Survey Circular 1292, 101 p. (Also available at http://pubs.usgs.gov/circ/circ1292/.) 
Table 1. Identification, sampling, and construction information for trend wells sampled for seven Groundwater Ambient Monitoring and Assessment (GAMA) study units.

[GAMA well identification number acronyms: San Diego Drainages study unit: SDALLV, Alluvial Basins study area; SDHDRK, Hard Rock study area; SDTEM, Temecula Valley study area; SDTEMFP, Temecula Valley study area flow-path well; SDWARN, Warner Valley study area. North San Francisco Bay study unit: NSFVOL, Volcanic Highlands study area; NSFVP, Valley and Plains study area; NSFWG, Wilson Grove Formation Highlands study area; NSFWGFP, Wilson Grove Formation Highlands study area flow-path well. Northern San Joaquin Basin study unit: COS, Cosumnes Basin study area; ESJ, Eastern San Joaquin Basin study area; NSJ-QPC, Uplands Basin study area; TRCY, Tracy Basin study area. Southern Sacramento Valley study unit: NAM, North American study area; SAM, South American study area; SOL, Solano study area; SSV-QPC, Uplands study area; SUI, Suisun-Fairfield study area; YOL, Yolo study area. San Fernando-San Gabriel study unit: ULASF, San Fernando study area; ULASG, San Gabriel study area. Monterey Bay and Salinas Valley Basins study unit: MSMB, Monterey Bay study area; MSPR, Paso Robles study area; MSSC, Santa Cruz study area; MSSV, Salinas Valley study area. Southeast San Joaquin Valley study unit: KING, Kings study area; KWH, Kaweah study area; TLR, Tulare Lake study area; TULE, Tule study area. Other abbreviations: ft, foot; LSD, land-surface datum; na, not available; NAVD 88, North American Vertical Datum of 1988]

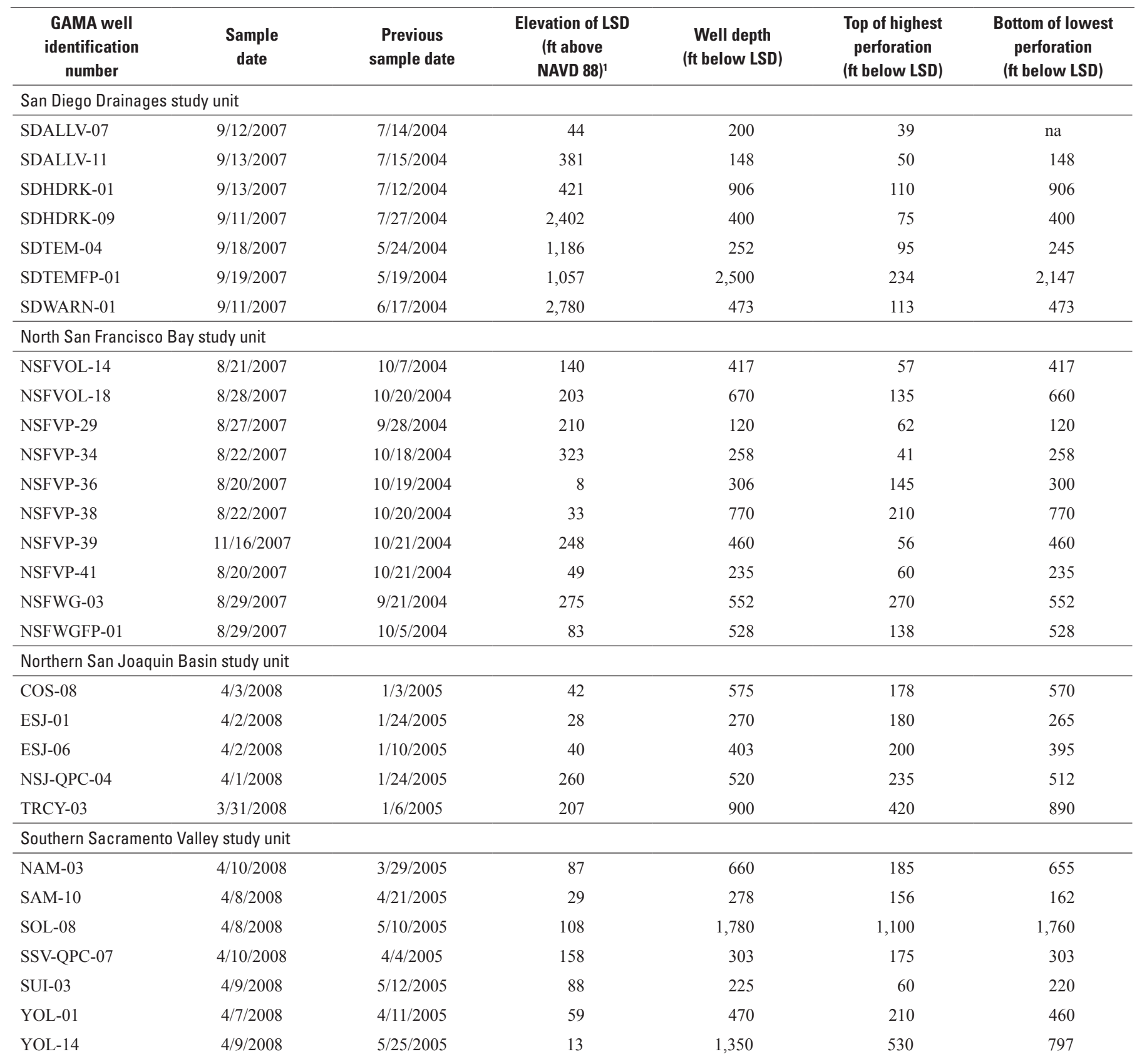


Table 1. Identification, sampling, and construction information for trend wells sampled for seven Groundwater Ambient Monitoring and Assessment (GAMA) study units. - Continued

[GAMA well identification number acronyms: San Diego Drainages study unit: SDALLV, Alluvial Basins study area; SDHDRK, Hard Rock study area; SDTEM, Temecula Valley study area; SDTEMFP, Temecula Valley study area flow-path well; SDWARN, Warner Valley study area. North San Francisco Bay study unit: NSFVOL, Volcanic Highlands study area; NSFVP, Valley and Plains study area; NSFWG, Wilson Grove Formation Highlands study area; NSFWGFP, Wilson Grove Formation Highlands study area flow-path well. Northern San Joaquin Basin study unit: COS, Cosumnes Basin study area; ESJ, Eastern San Joaquin Basin study area; NSJ-QPC, Uplands Basin study area; TRCY, Tracy Basin study area. Southern Sacramento Valley study unit: NAM, North American study area; SAM, South American study area; SOL, Solano study area; SSV-QPC, Uplands study area; SUI, Suisun-Fairfield study area; YOL, Yolo study area. San Fernando-San Gabriel study unit: ULASF, San Fernando study area; ULASG, San Gabriel study area. Monterey Bay and Salinas Valley Basins study unit: MSMB, Monterey Bay study area; MSPR, Paso Robles study area; MSSC, Santa Cruz study area; MSSV, Salinas Valley study area. Southeast San Joaquin Valley study unit: KING, Kings study area; KWH, Kaweah study area; TLR, Tulare Lake study area; TULE, Tule study area. Other abbreviations: ft, foot; LSD, land-surface datum; na, not available; NAVD 88, North American Vertical Datum of 1988]

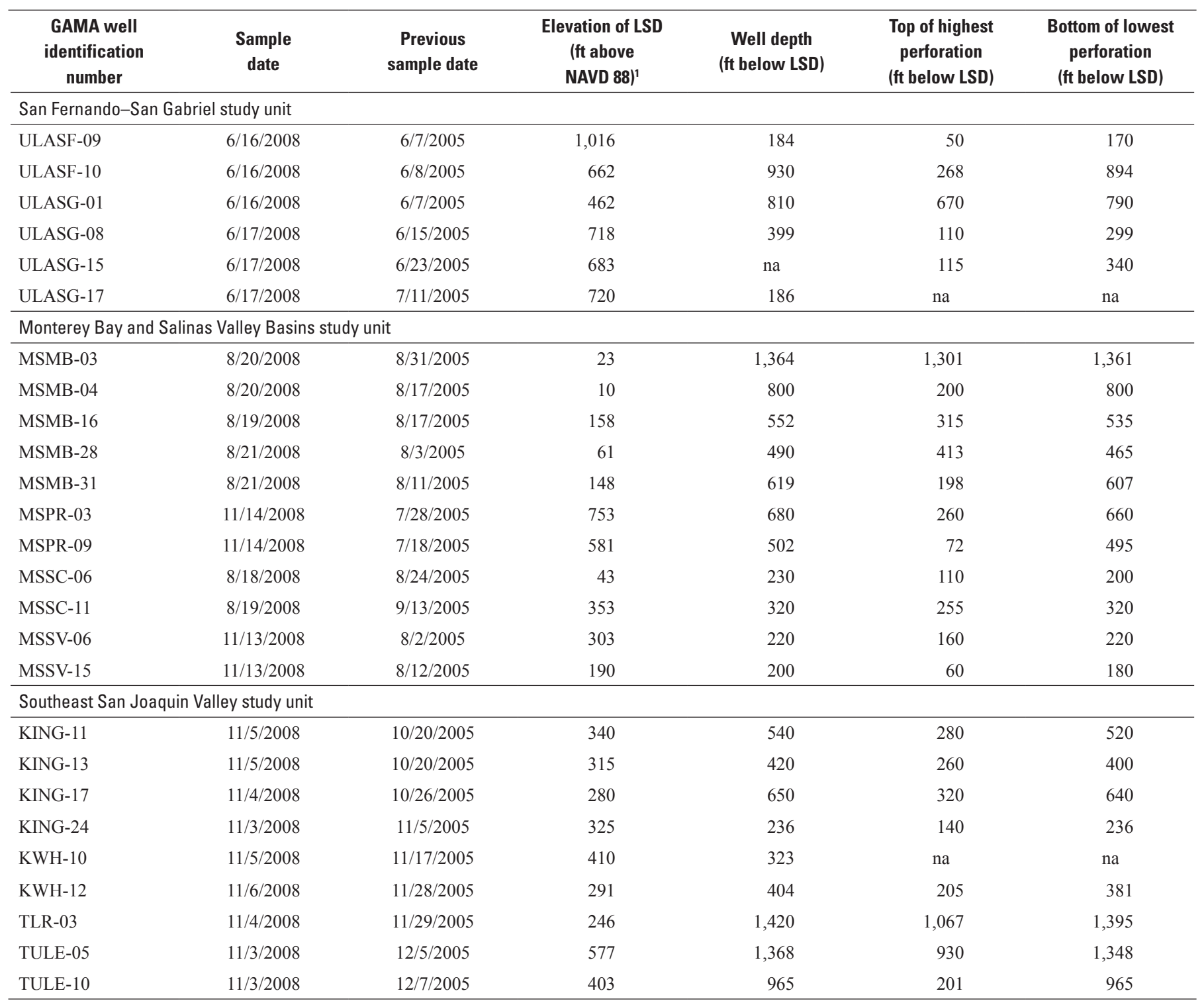

${ }^{1}$ LSD is a datum plane that is approximately at land surface at each well. The altitude of the LSD is described in feet above the North American Vertical Datum of 1988. 

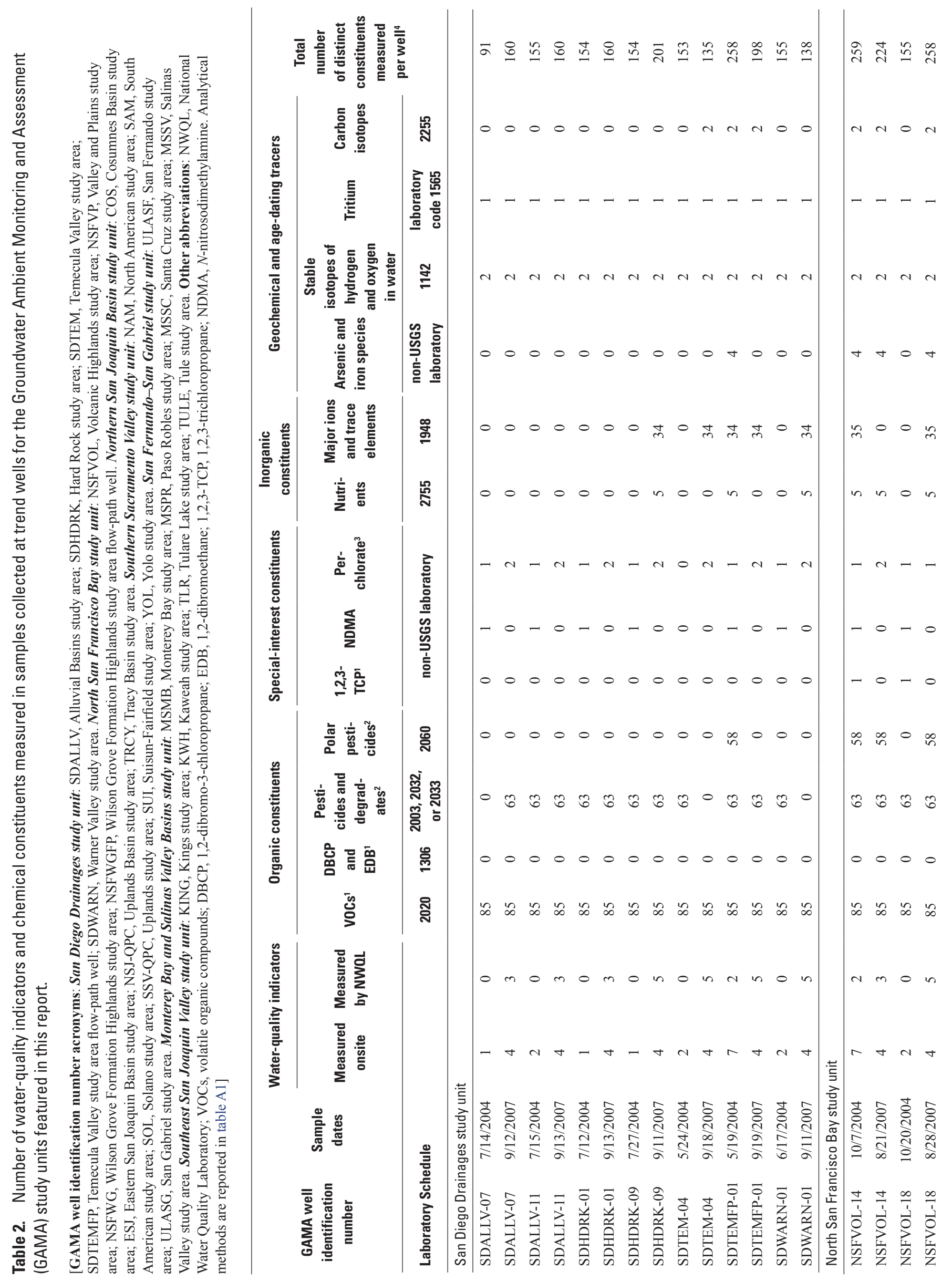


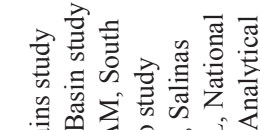

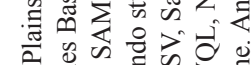

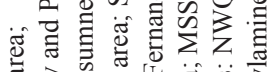

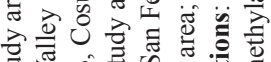
है w

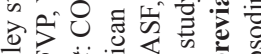

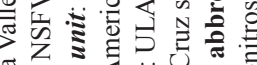

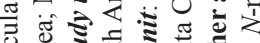

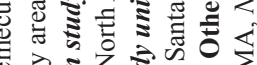
ए

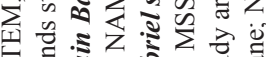

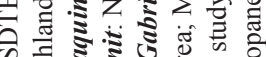
की 表 ज约

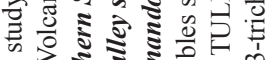
प

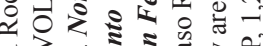

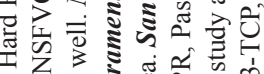

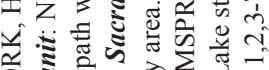

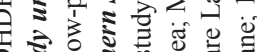

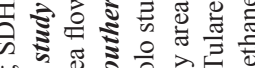

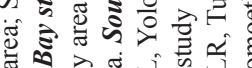
늘

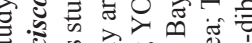
纯

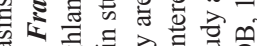

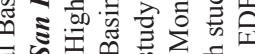
의

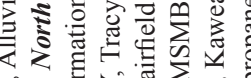

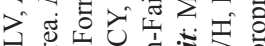

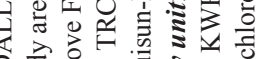

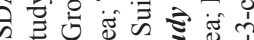

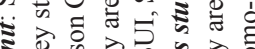

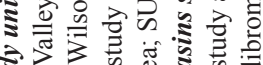

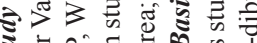
5

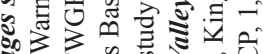

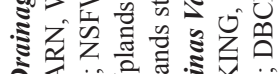

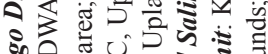

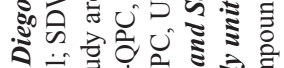

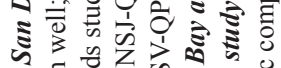
के 焉

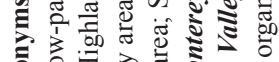
원

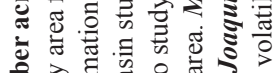

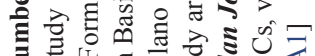

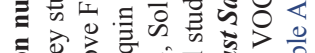

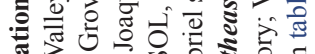

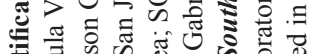

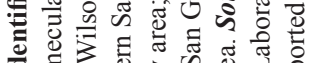

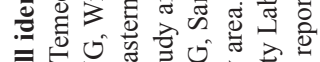

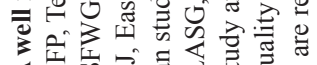

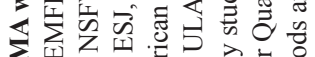

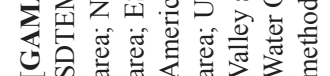

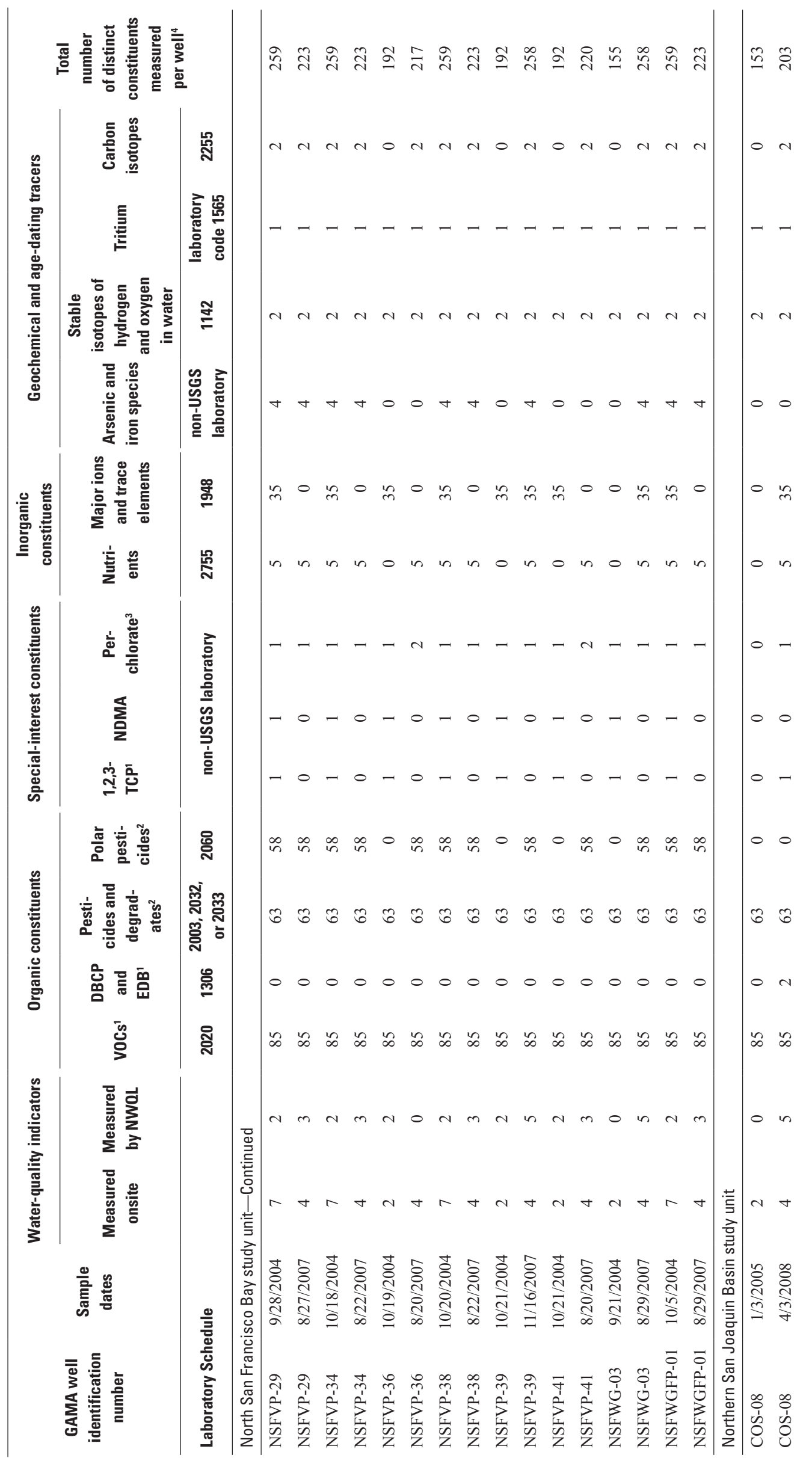



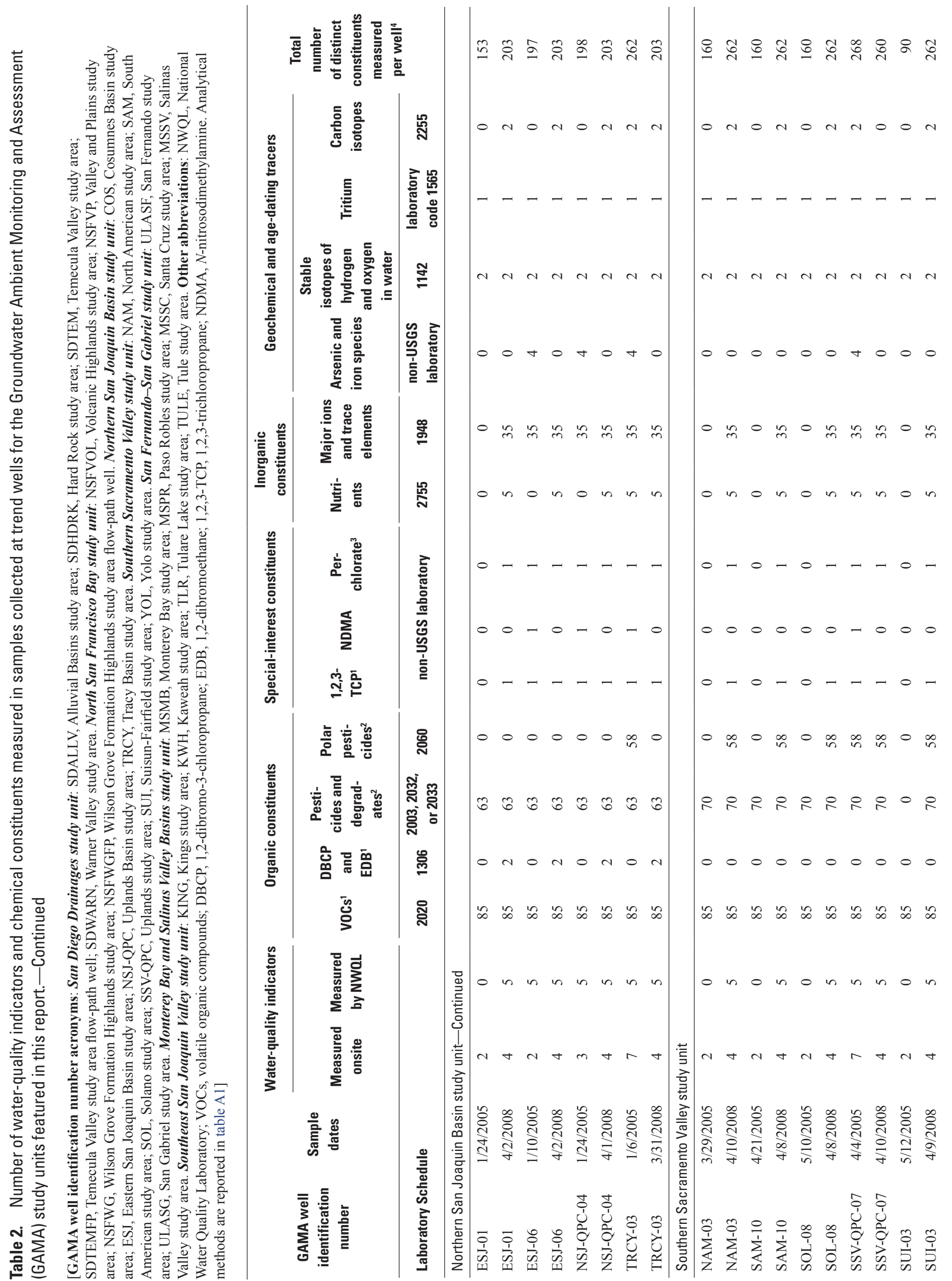
Tables

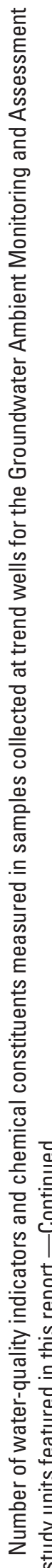

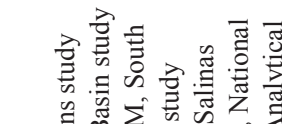

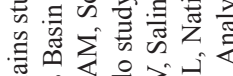

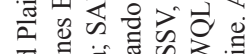

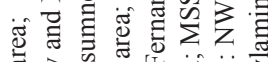

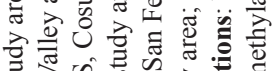

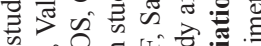

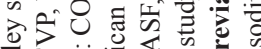

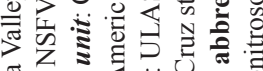

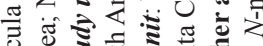

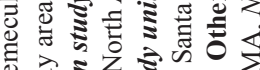

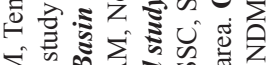

$\sum_{1}^{\infty} 00$

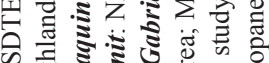

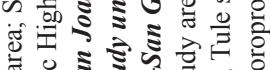

की ज्ञ है

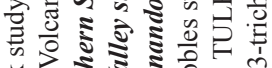

눙

군

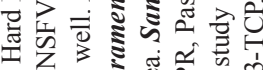

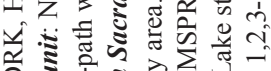

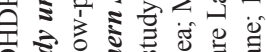

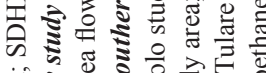

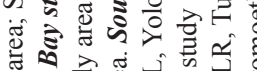

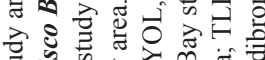

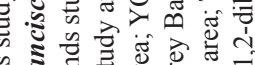

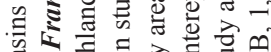

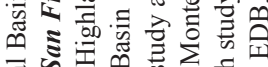

ज़

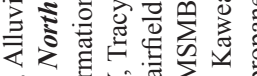

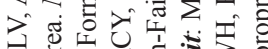

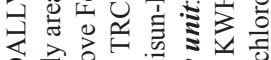

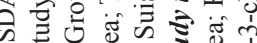

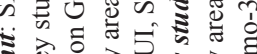

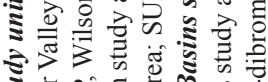

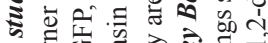

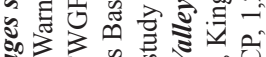

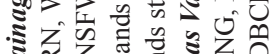

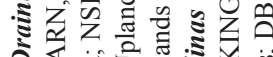

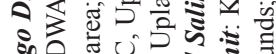

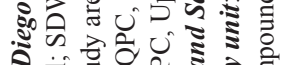

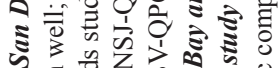

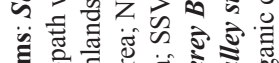

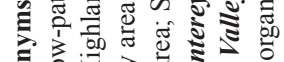

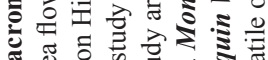

可语.

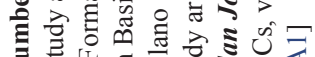

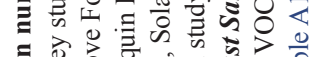

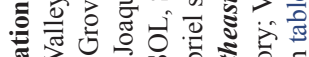

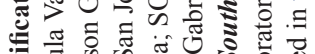

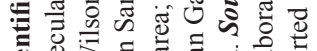

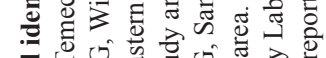

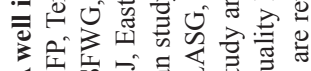

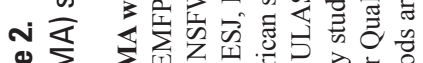

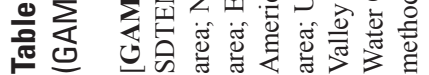

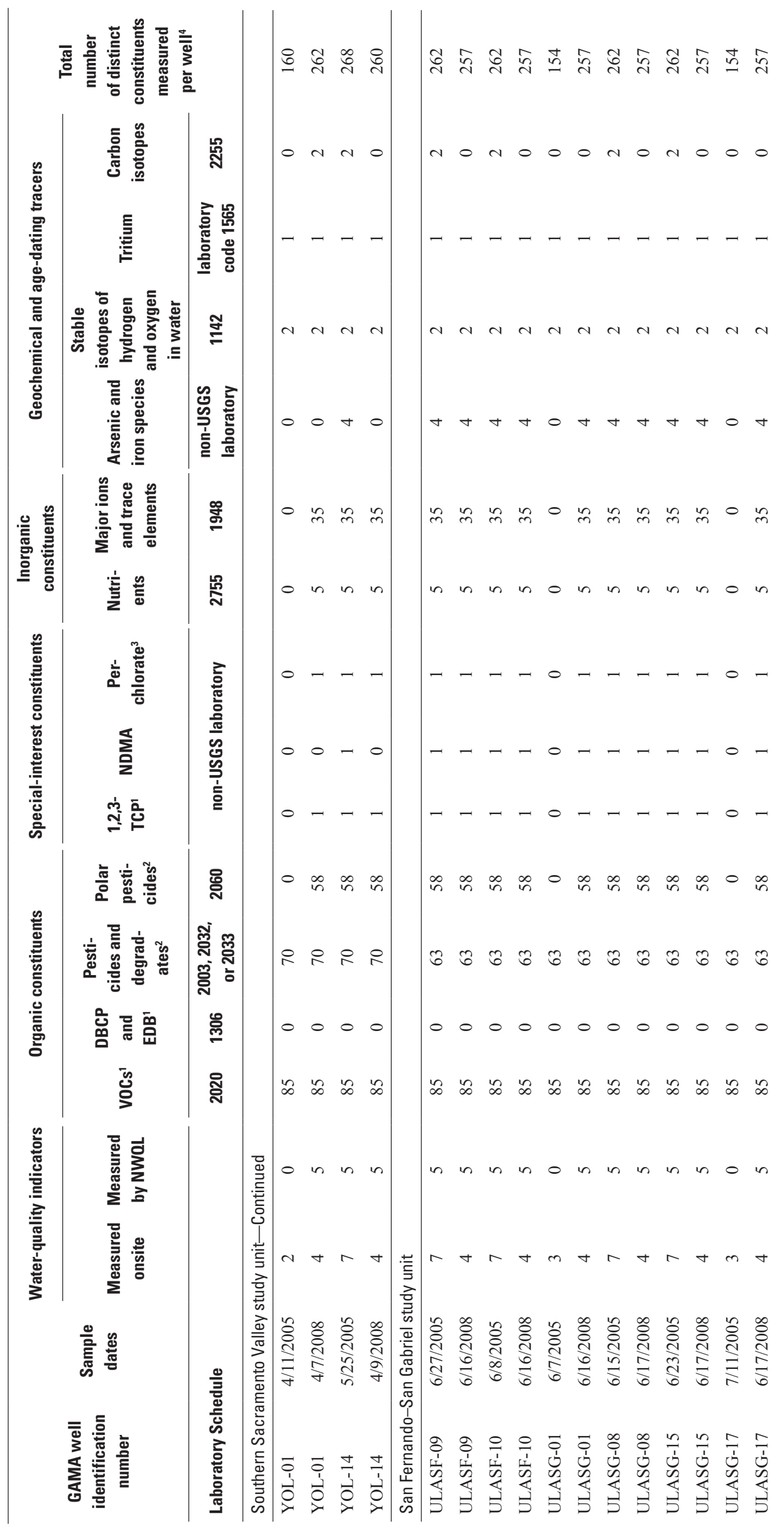



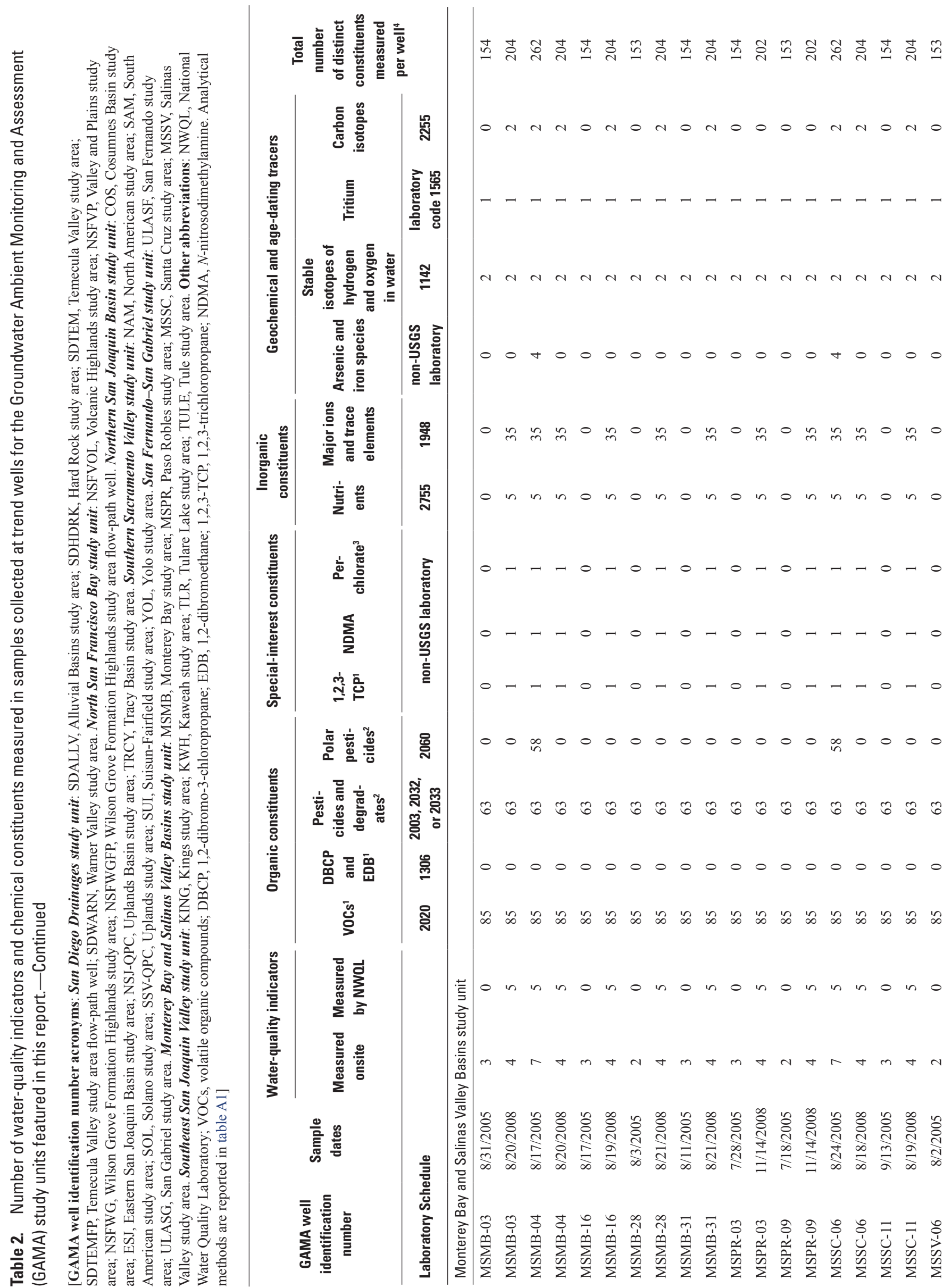


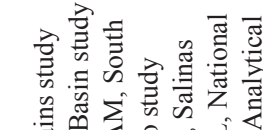

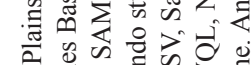

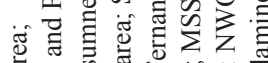

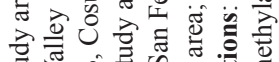

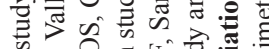

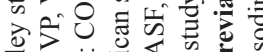

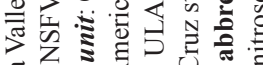

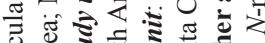
ठึ.

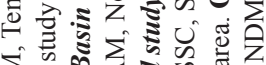
$\sum_{11}^{n} \begin{aligned} & 0 \\ & 0\end{aligned}$

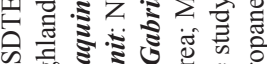

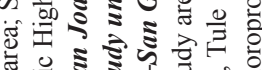

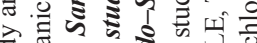

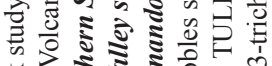
눙

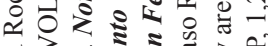

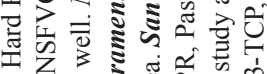

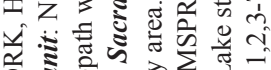
5

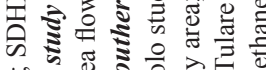

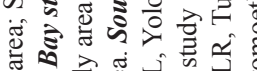

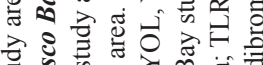

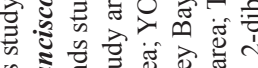
ज

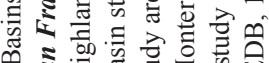

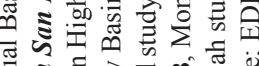
है

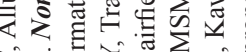
造论

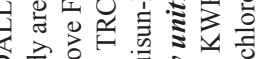

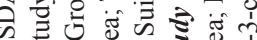

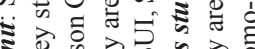

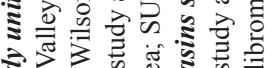
긴 3 है 5

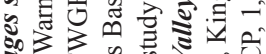

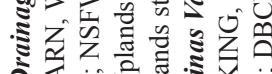
0

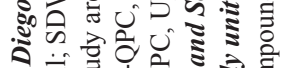

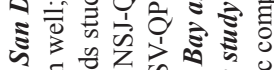

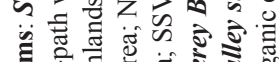

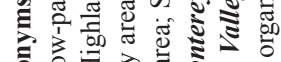

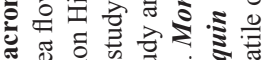

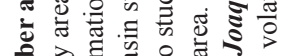

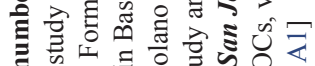

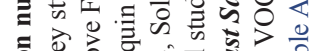

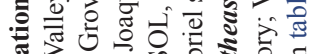

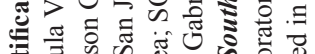

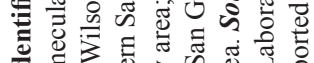

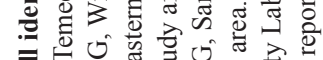

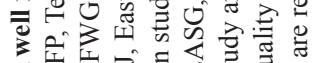

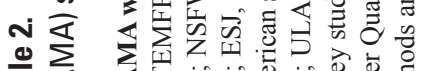

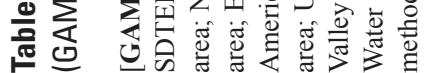

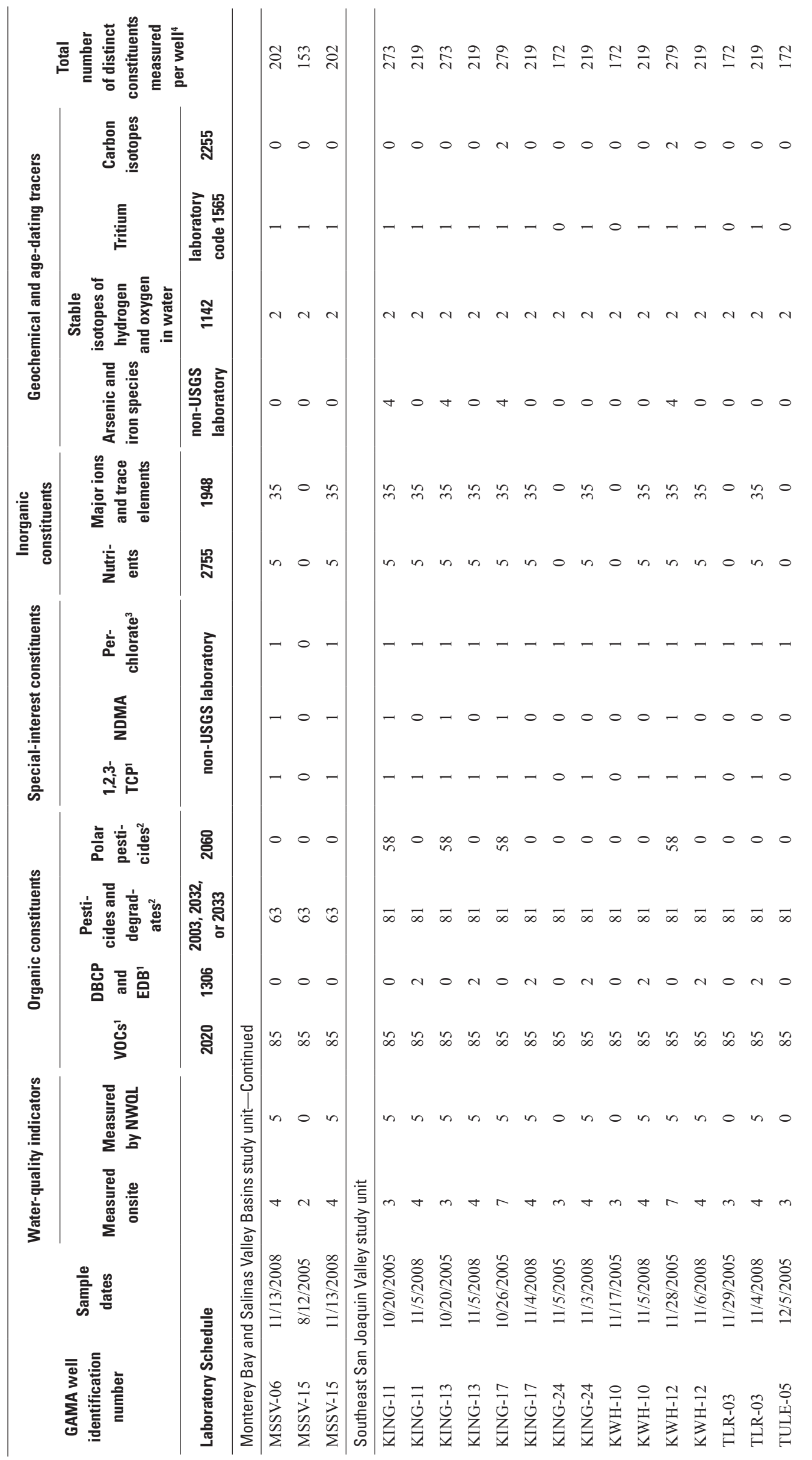



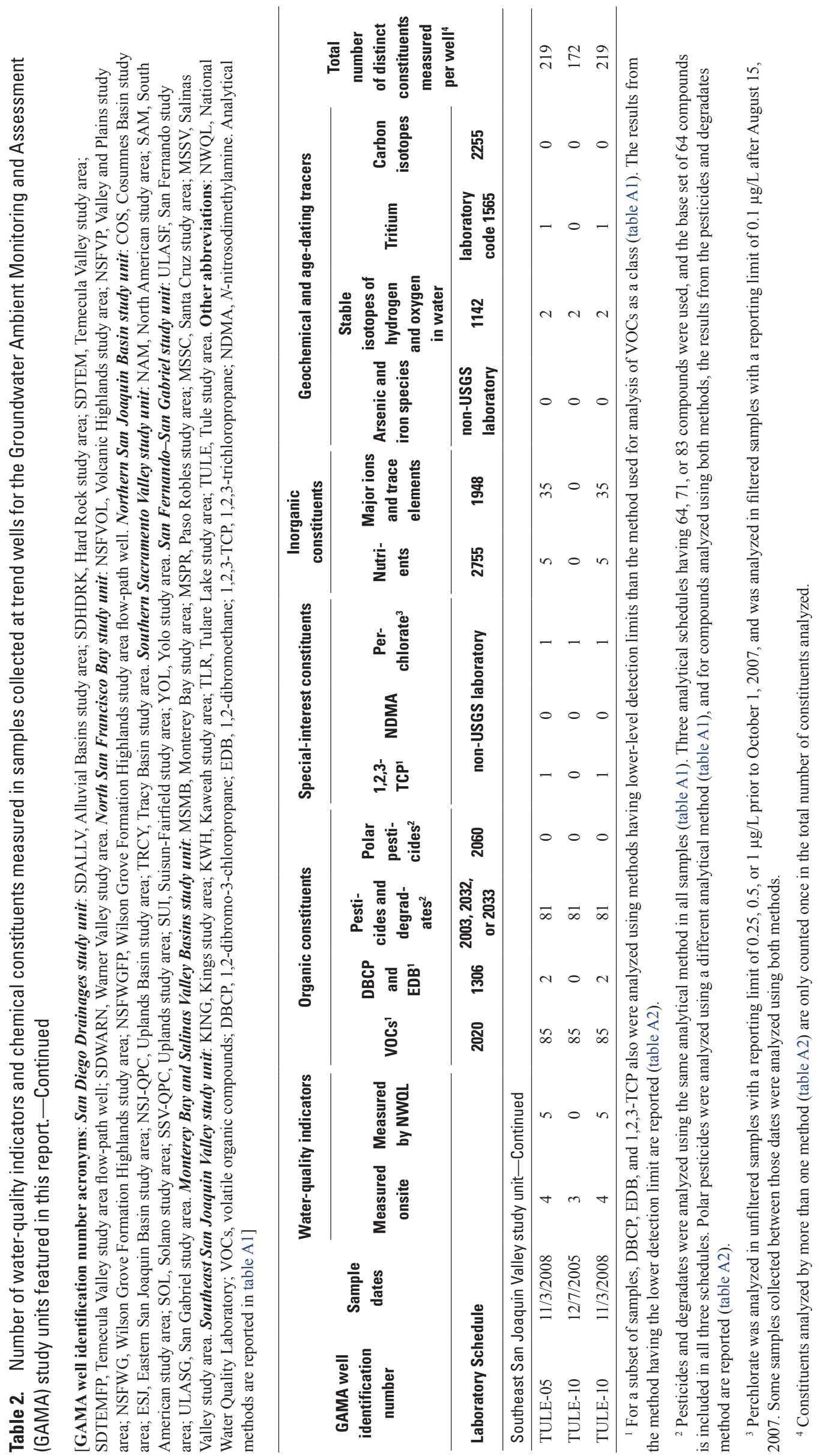
Tables $\quad 41$

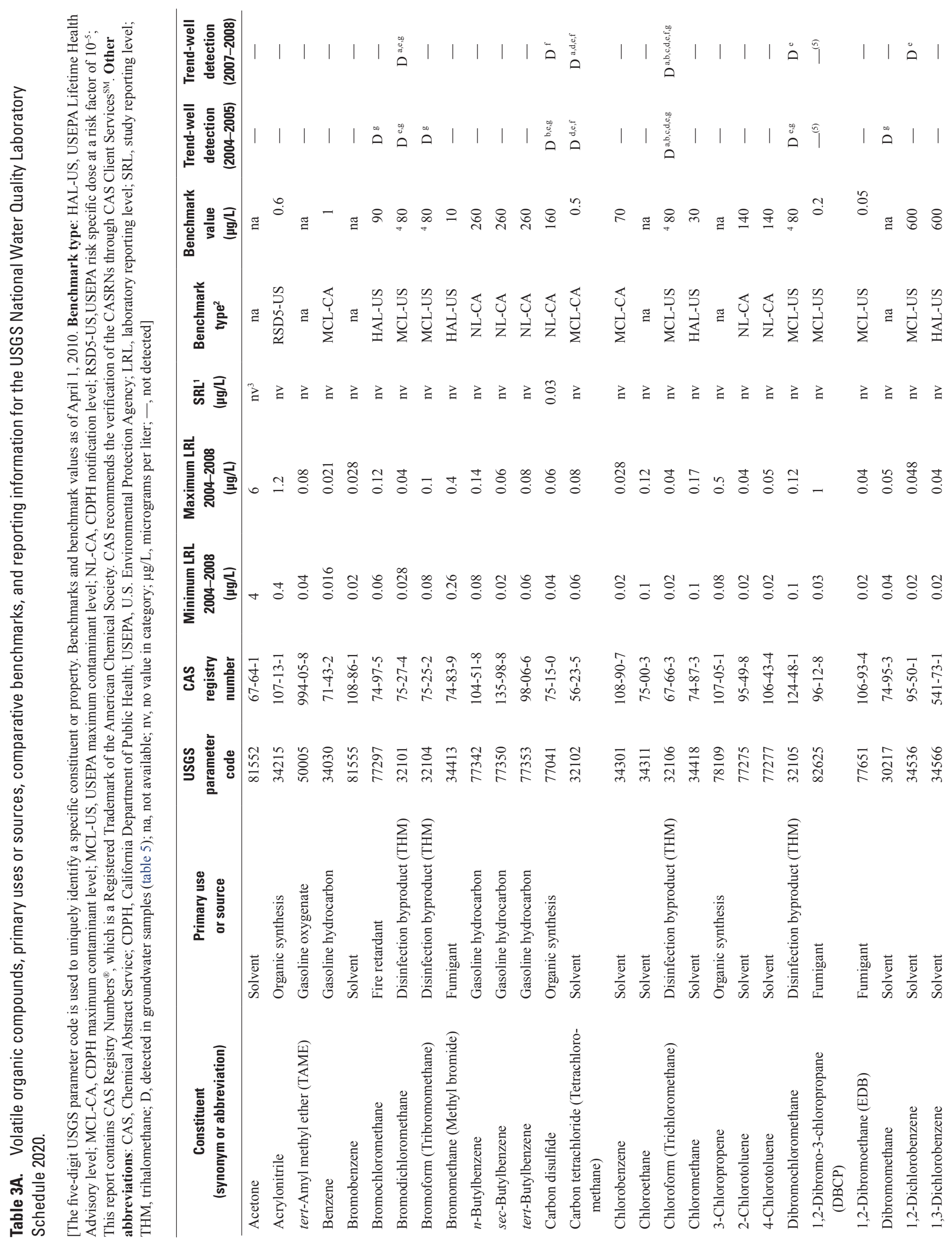




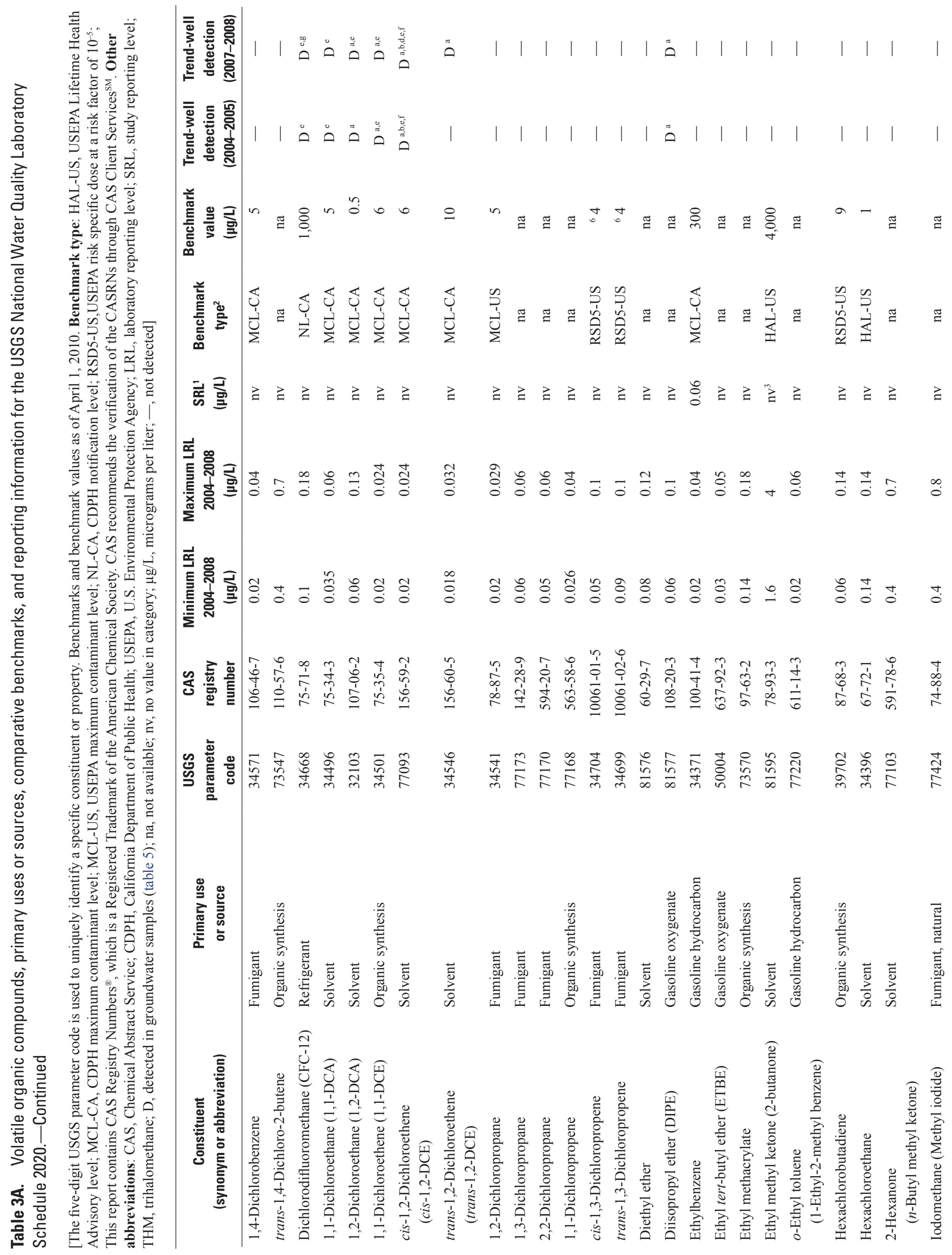




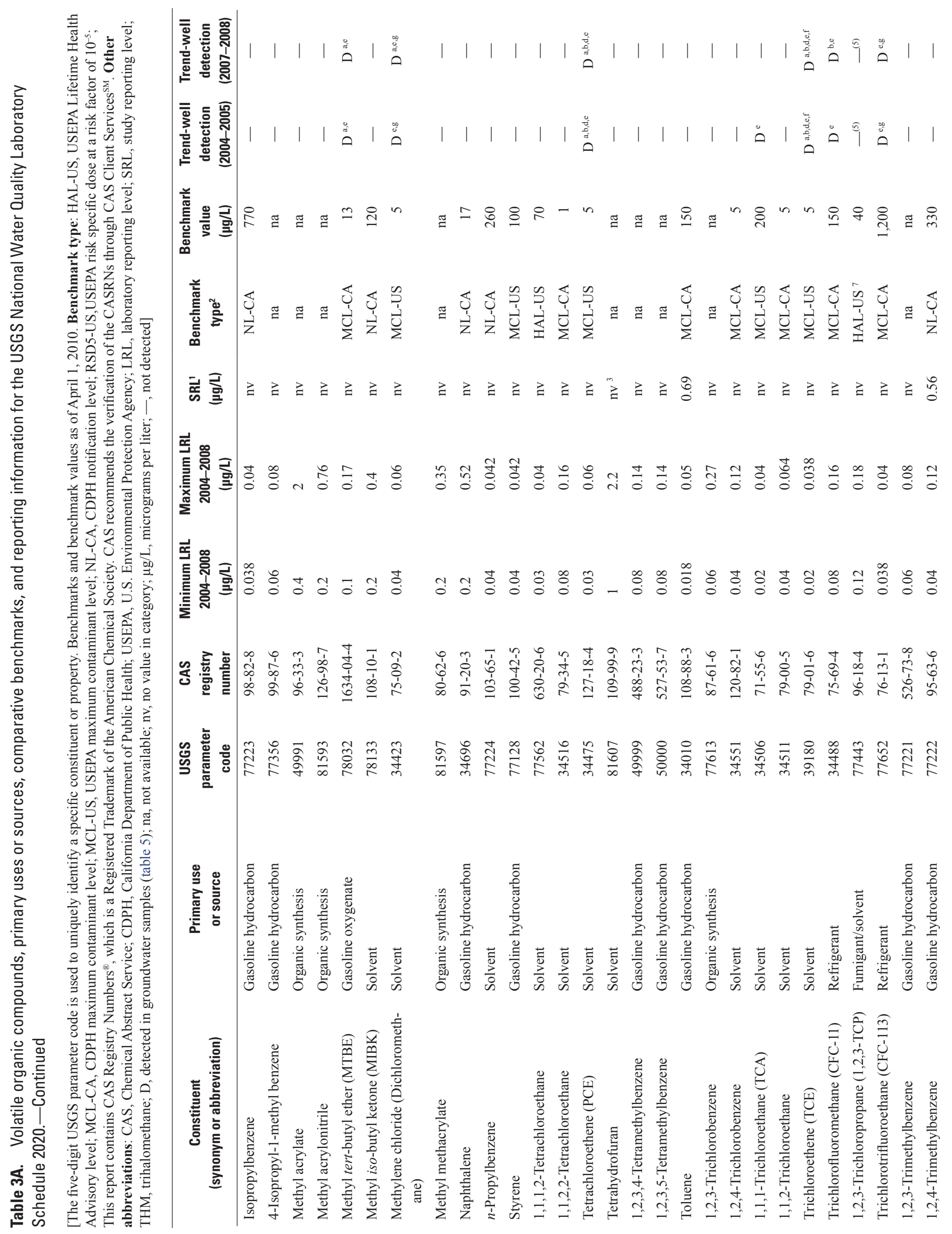




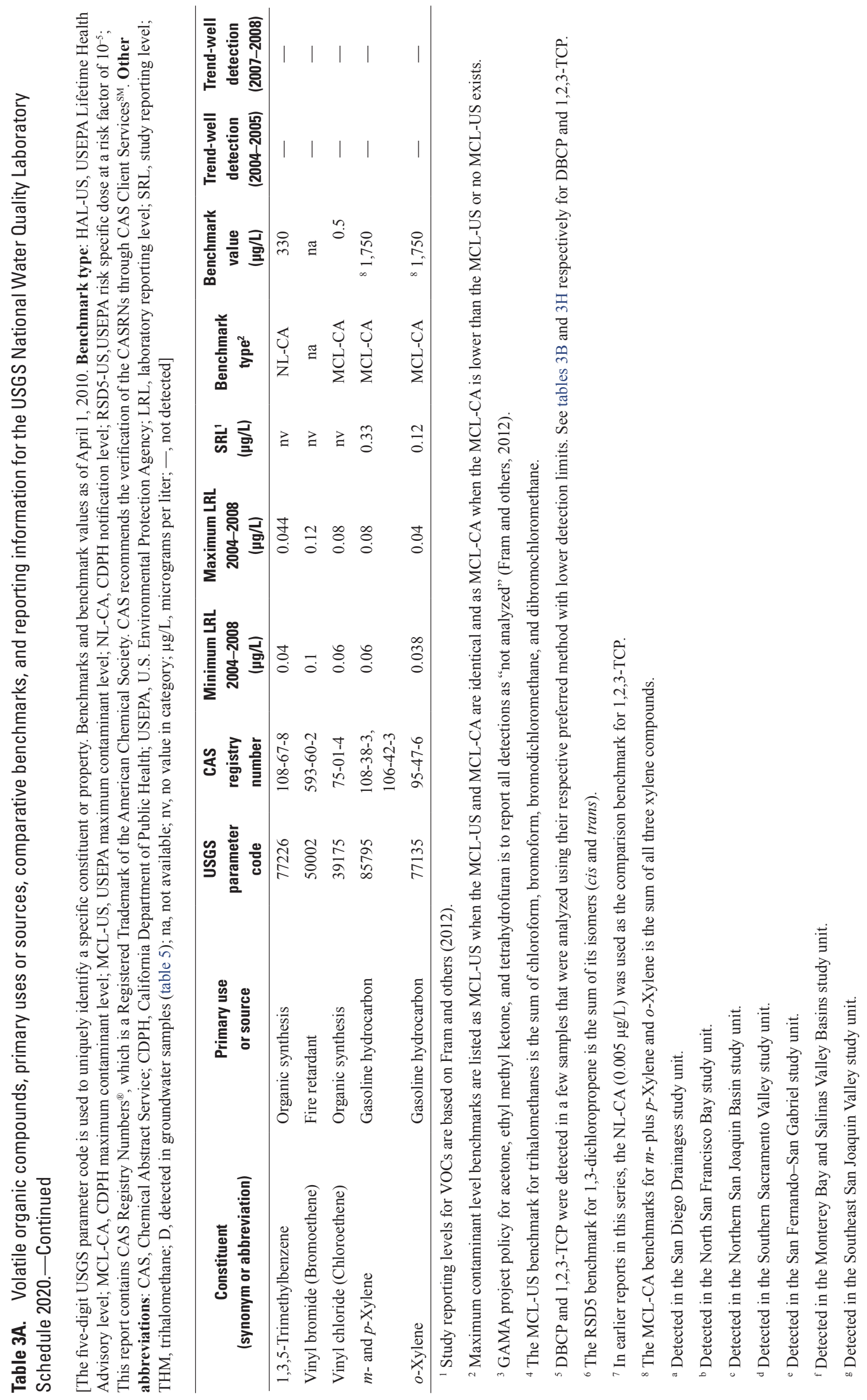




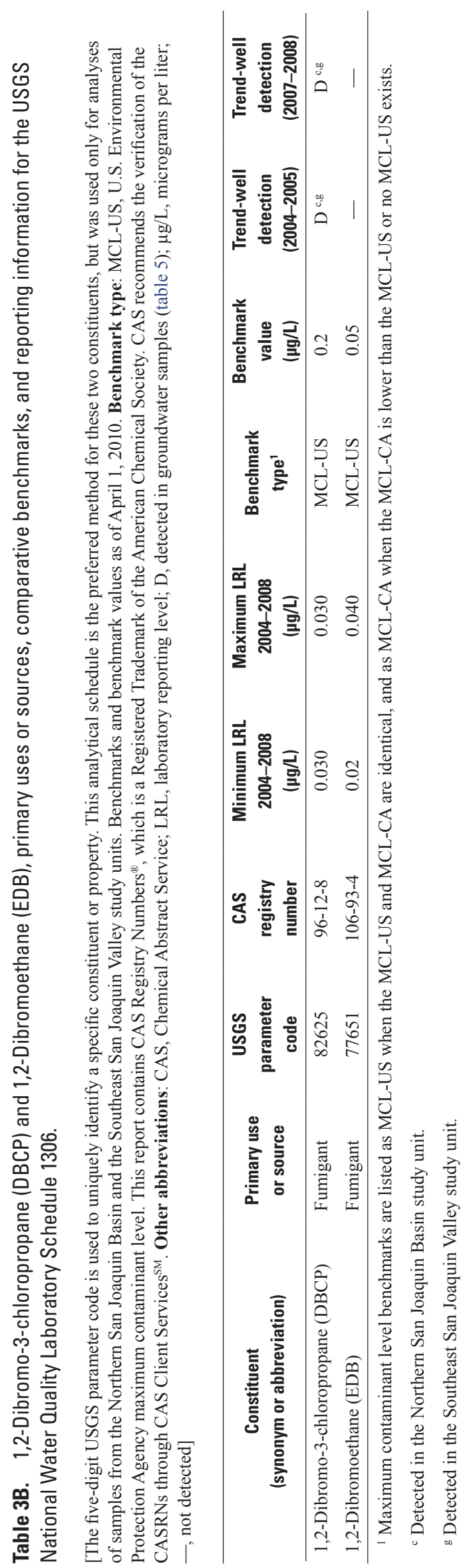




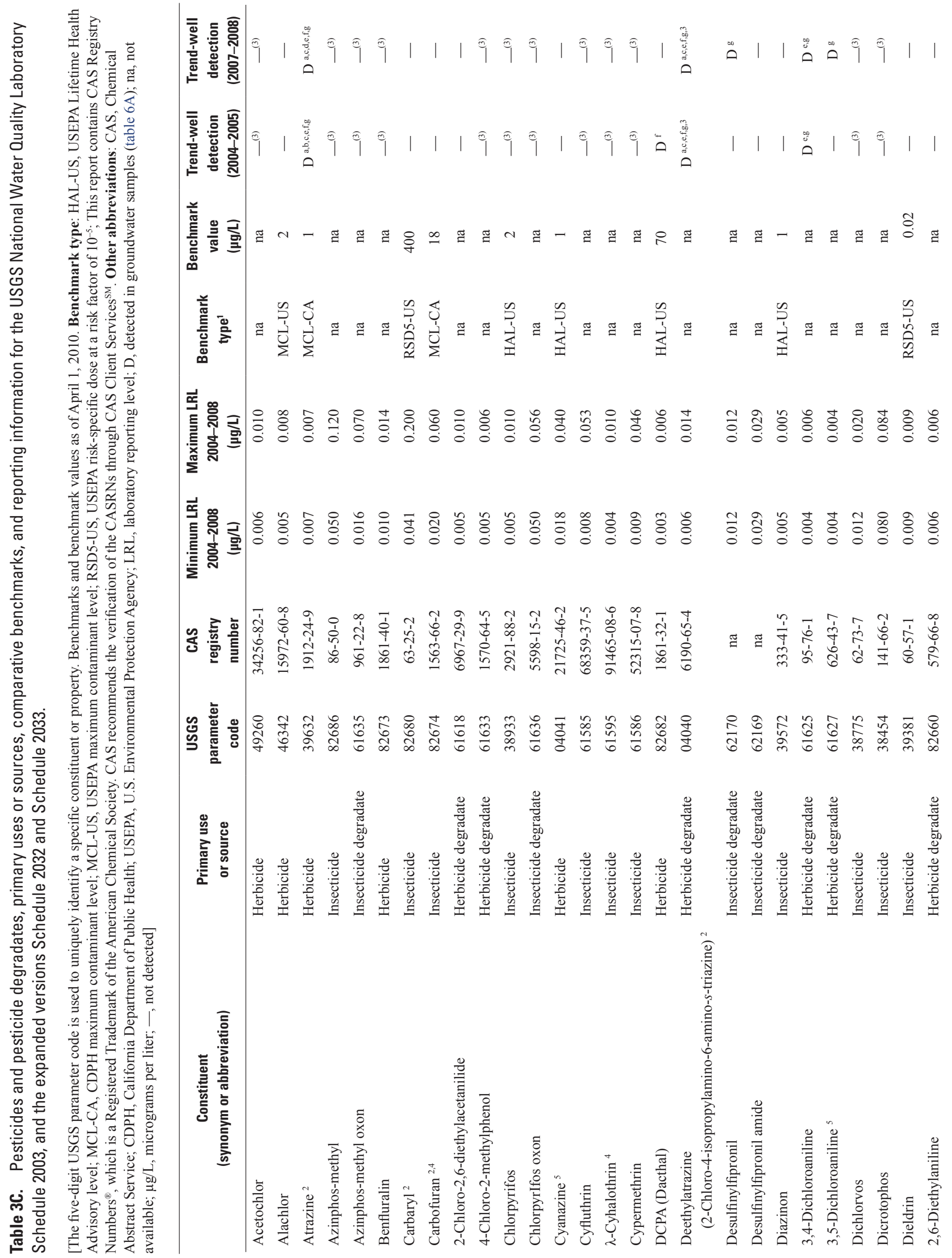


Tables $\quad 47$

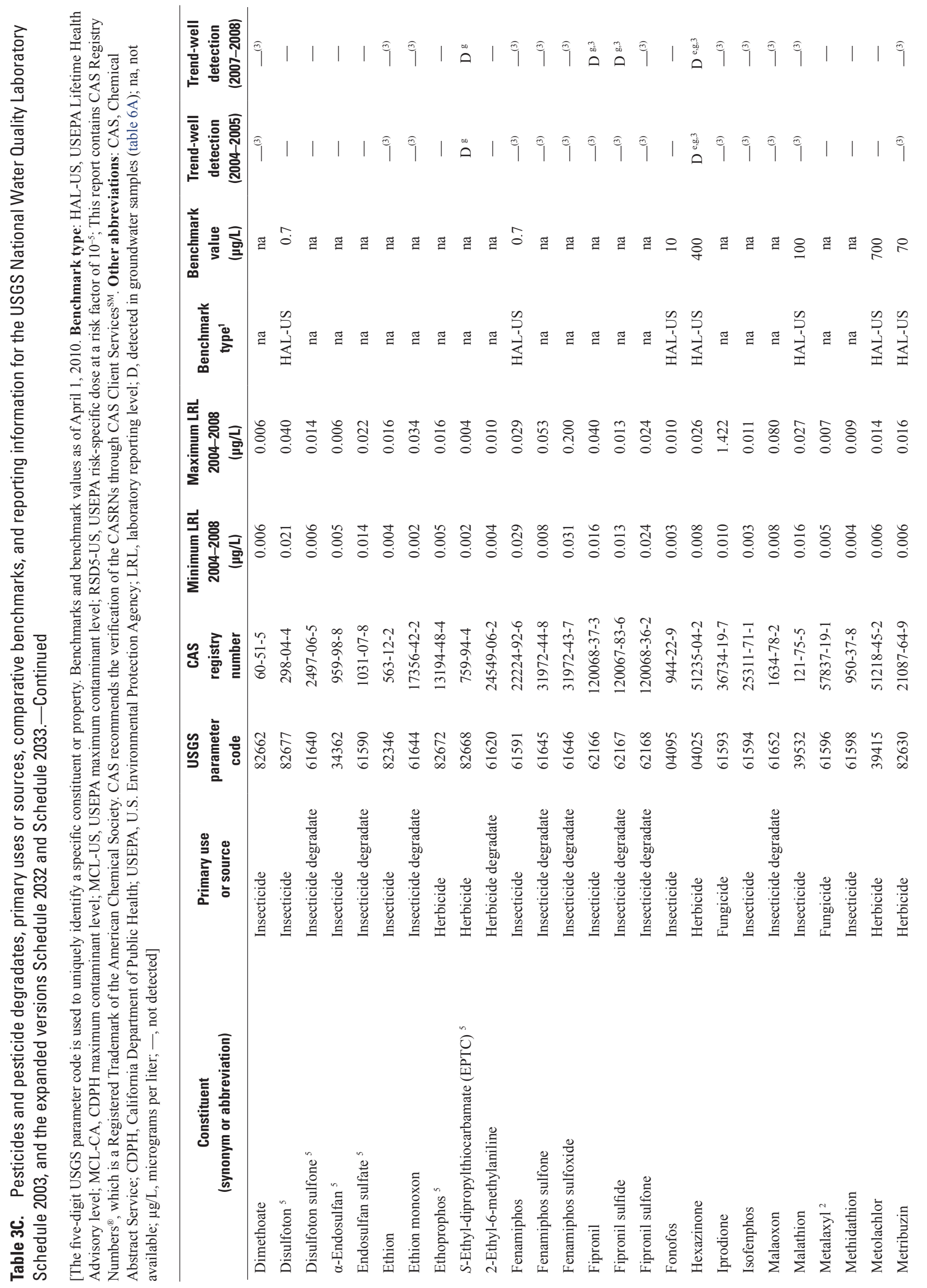




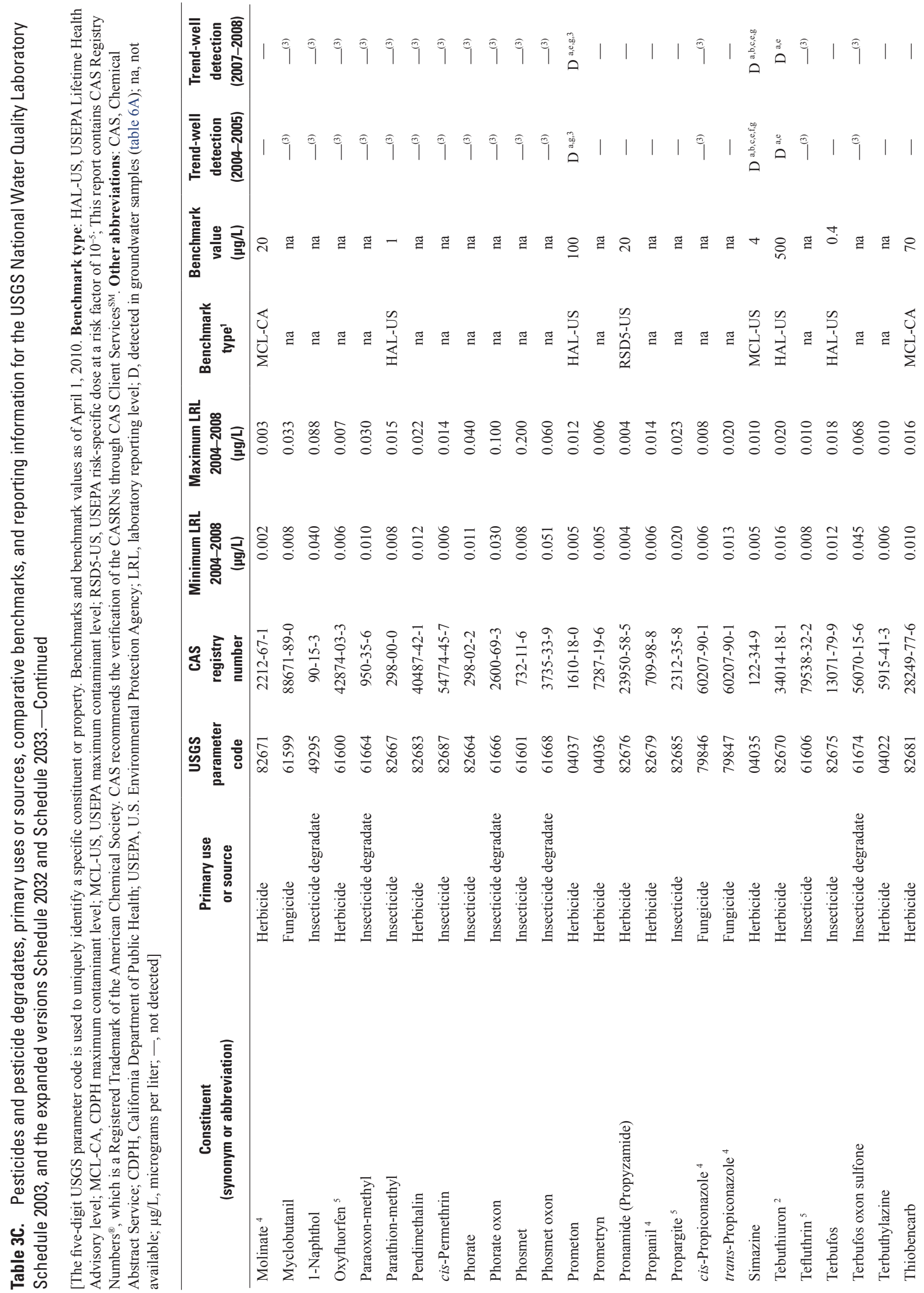




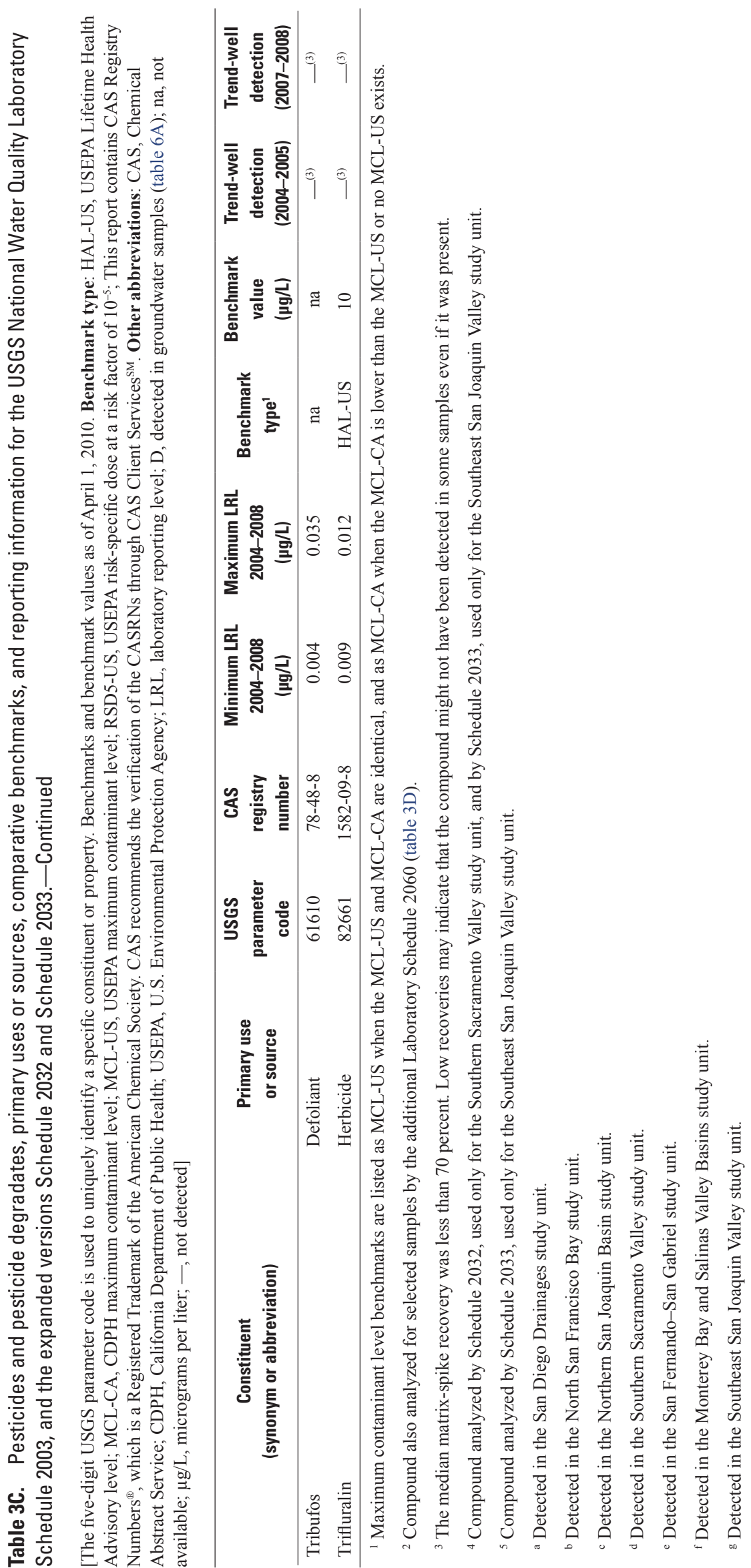




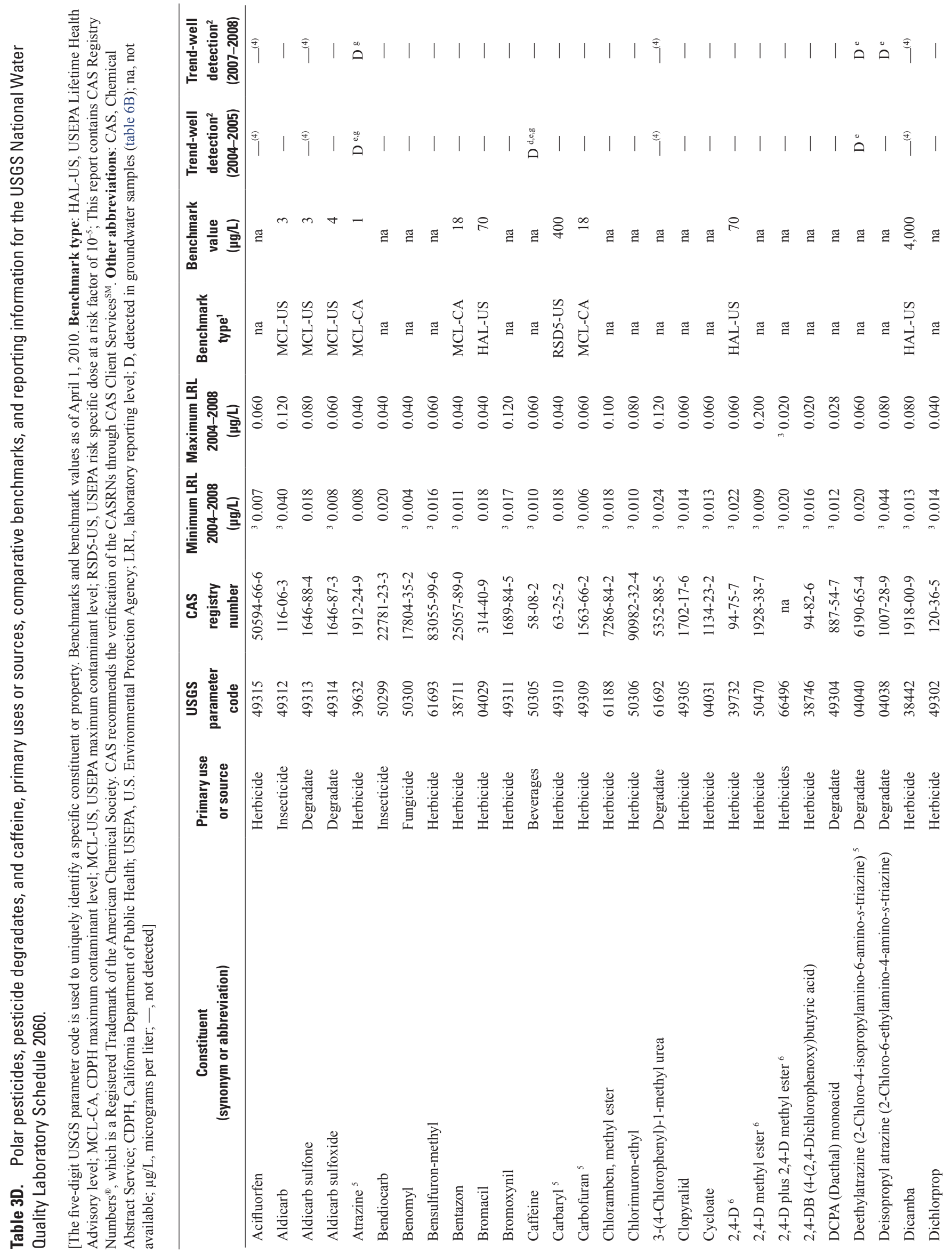




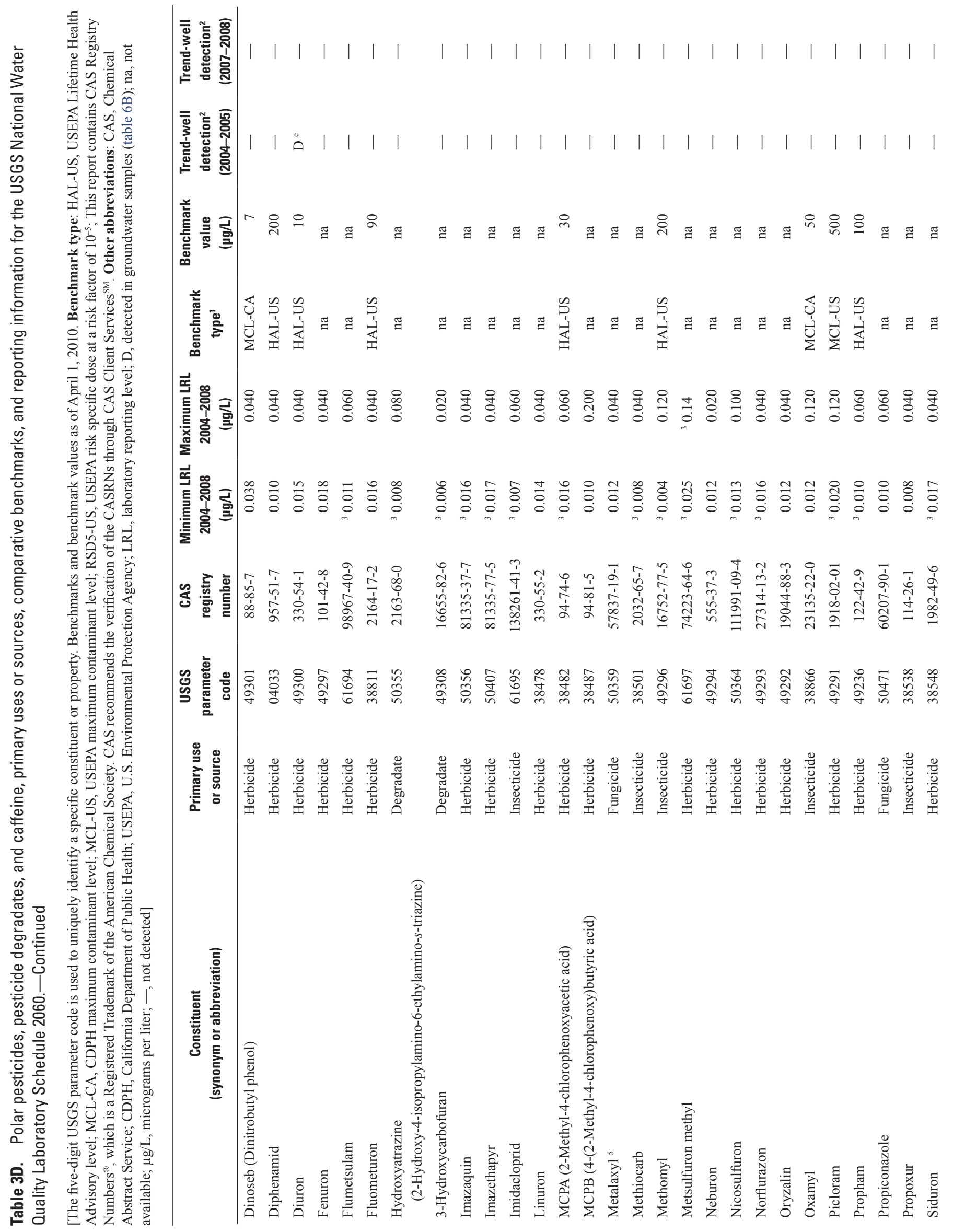




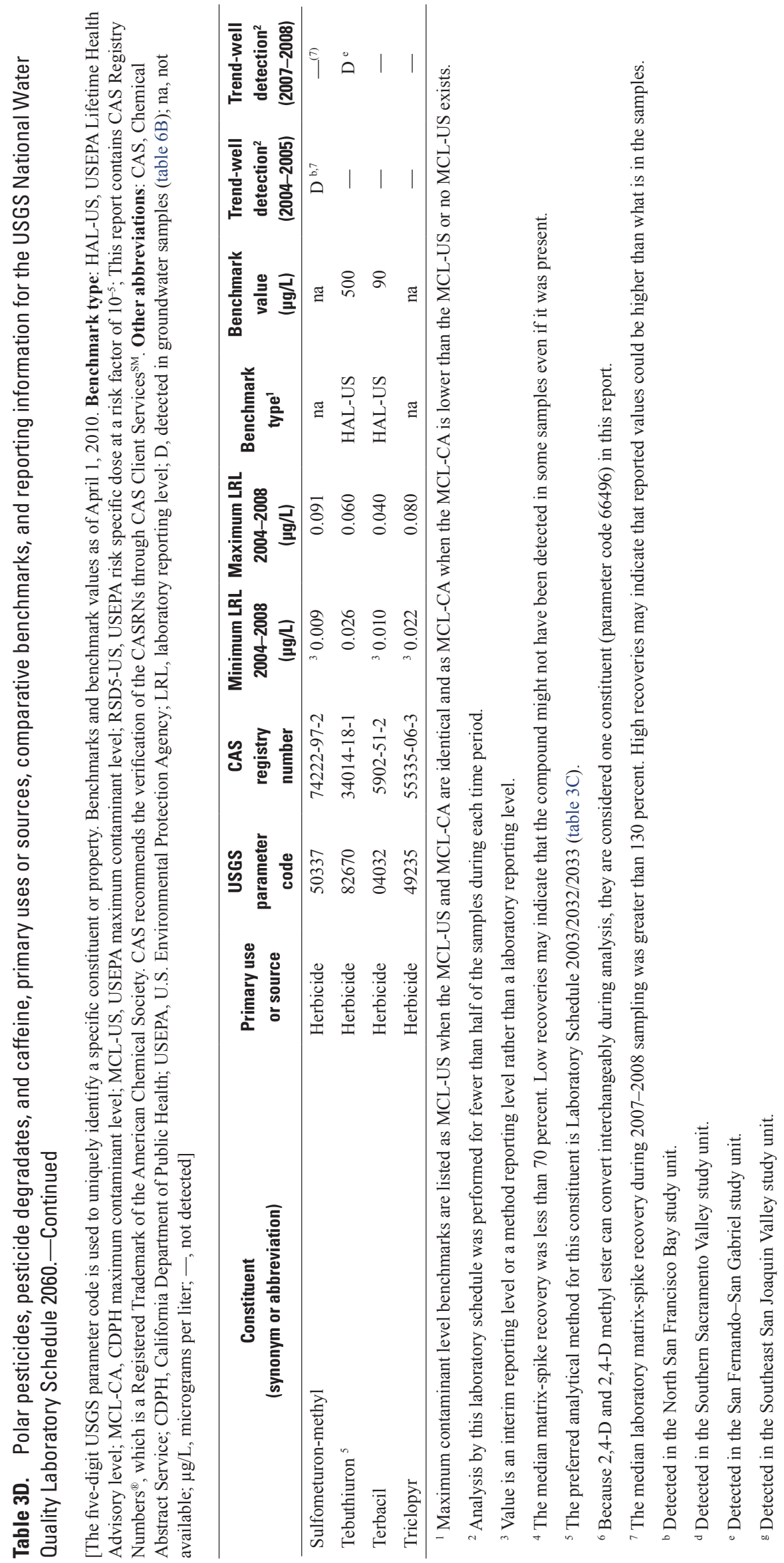




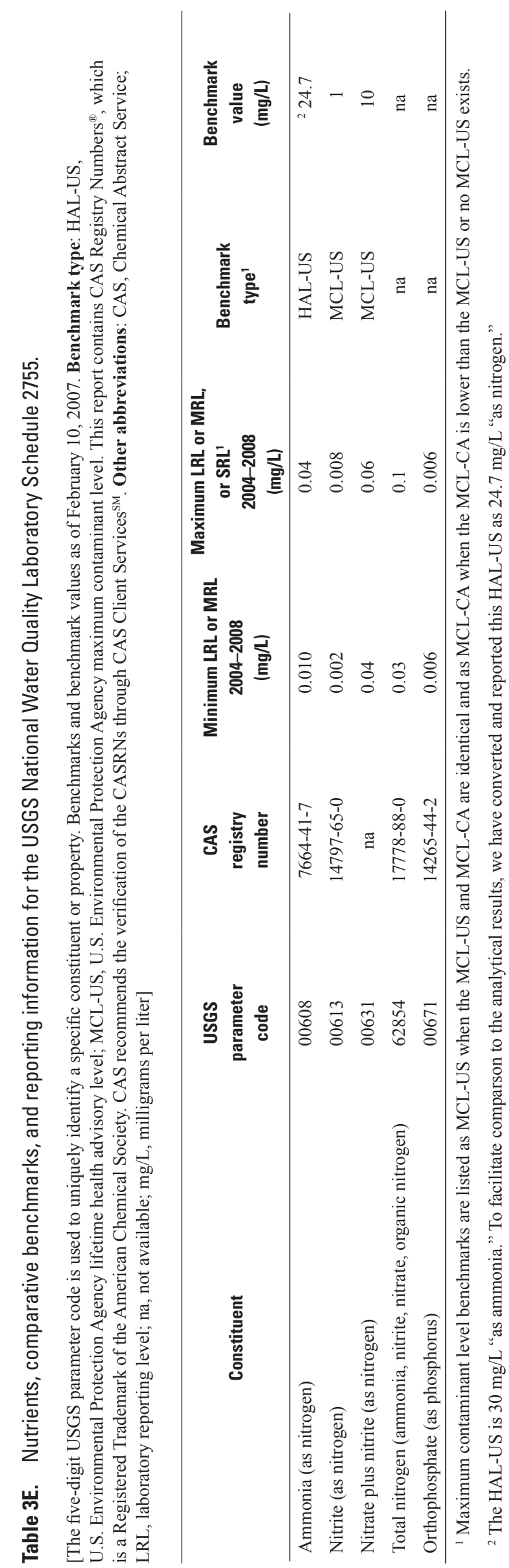




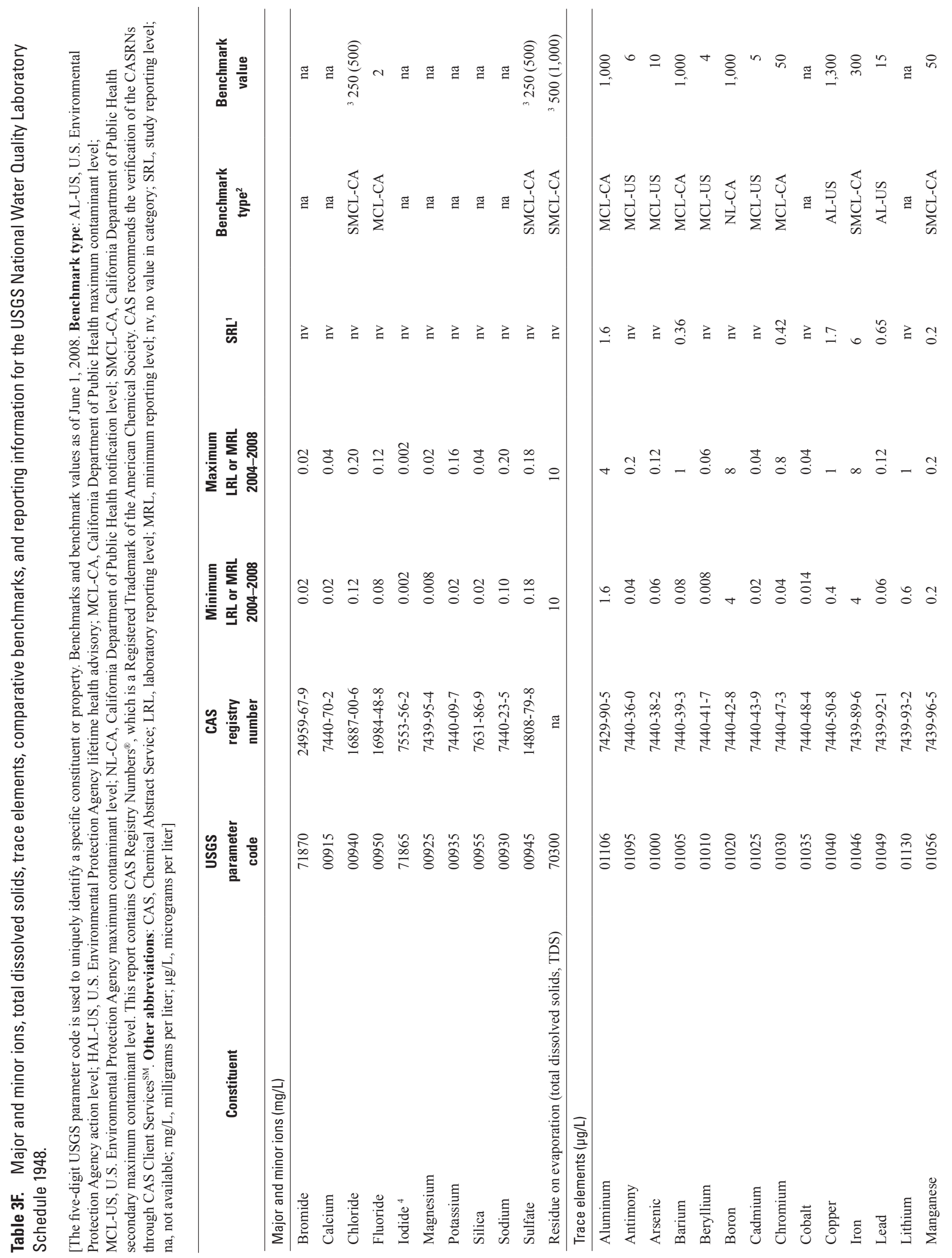




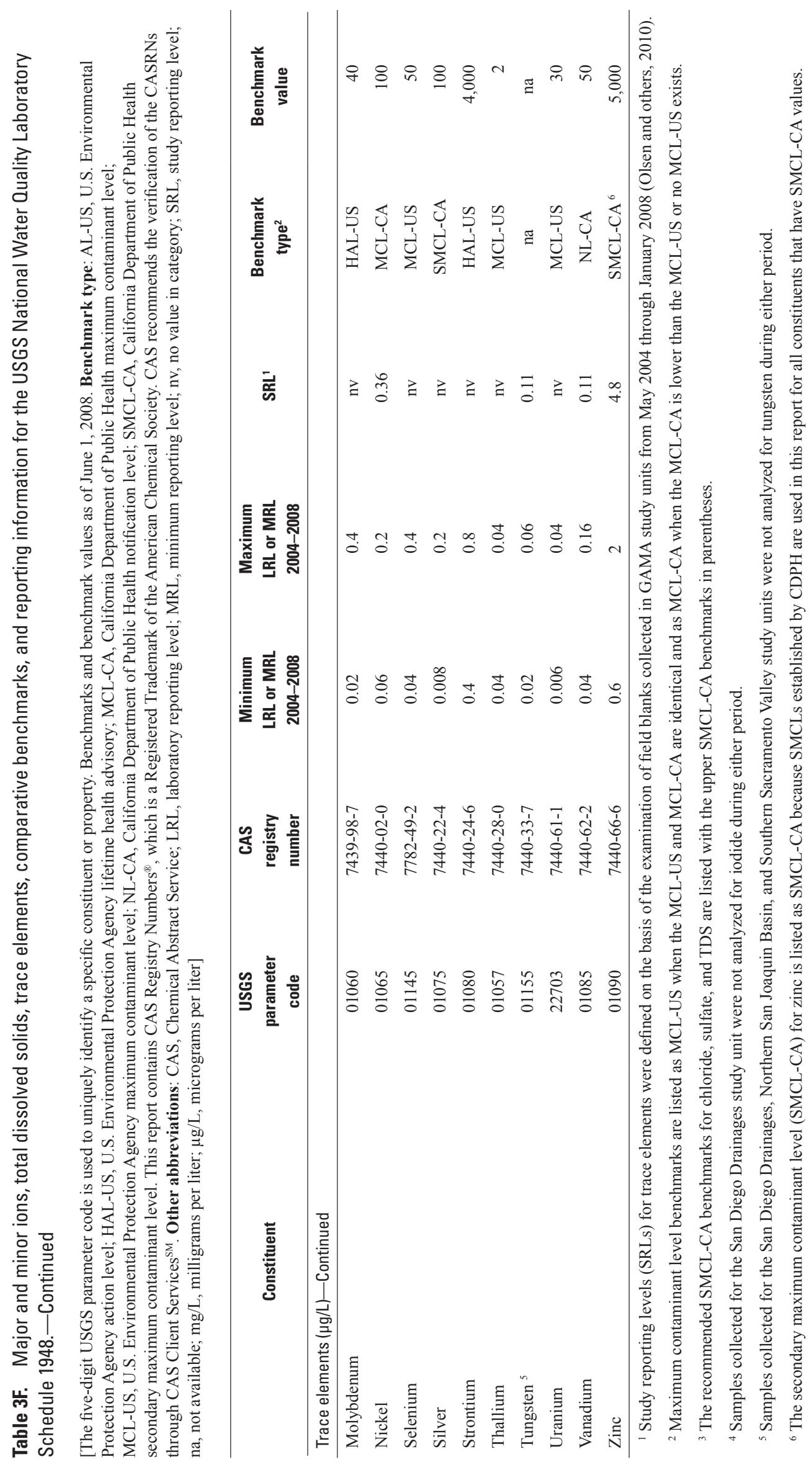


Table 3G. Arsenic and iron species, comparative benchmarks, and reporting information for the USGS Trace Metal Laboratory, Boulder, Colorado.

[The five-digit USGS parameter code is used to uniquely identify a specific constituent or property. Benchmarks and benchmark values as of April 1, 2010. Benchmark type: MCL-CA, California Department of Public Health maximum contaminant level; MCL-US, U.S. Environmental Protection Agency maximum contaminant level; SMCL-CA, California Department of Public Health secondary maximum contaminant level. This report contains CAS Registry Numbers ${ }^{\circledR}$, which is a Registered Trademark of the American Chemical Society. CAS recommends the verification of the CASRNs through CAS Client Services ${ }^{\mathrm{SM}}$. Other abbreviations: CAS, Chemical Abstract Service; MDL, method detection limit; NWQL, USGS National Water Quality Laboratory; na, not available; $\mu \mathrm{g} / \mathrm{L}$, micrograms per liter]

\begin{tabular}{lccccc}
\hline $\begin{array}{c}\text { Constituent } \\
\text { (valence state) }\end{array}$ & $\begin{array}{c}\text { USGS } \\
\text { parameter code }\end{array}$ & $\begin{array}{c}\text { CAS } \\
\text { registry number }\end{array}$ & $\begin{array}{c}\text { MDL } \\
(\boldsymbol{\mu g} / \mathbf{L})\end{array}$ & $\begin{array}{c}\text { Benchmark } \\
\text { type }^{\mathbf{1}}\end{array}$ & $\begin{array}{c}\text { Benchmark level } \\
(\boldsymbol{\mu g} / \mathbf{L})\end{array}$ \\
\hline Arsenic (III) & 99034 & $22569-72-8$ & 1 & na & MCL-US \\
Arsenic (total) ${ }^{2}$ & 99033 & $7440-38-2$ & 0.5 & na & na \\
Iron (II) & 01047 & $7439-89-6$ & 2 & SMCL-CA \\
Iron (total) ${ }^{2}$ & 01046 & $7439-89-6$ & 2 & 300 \\
\hline
\end{tabular}

${ }^{1}$ Maximum contaminant level benchmarks are listed as MCL-US when the MCL-US and MCL-CA are identical and as MCL-CA when the MCL-CA is lower than the MCL-US or no MCL-US exists.

${ }^{2}$ The preferred analytical method for this constituent is NWQL Schedule 1948 (table 3F). 


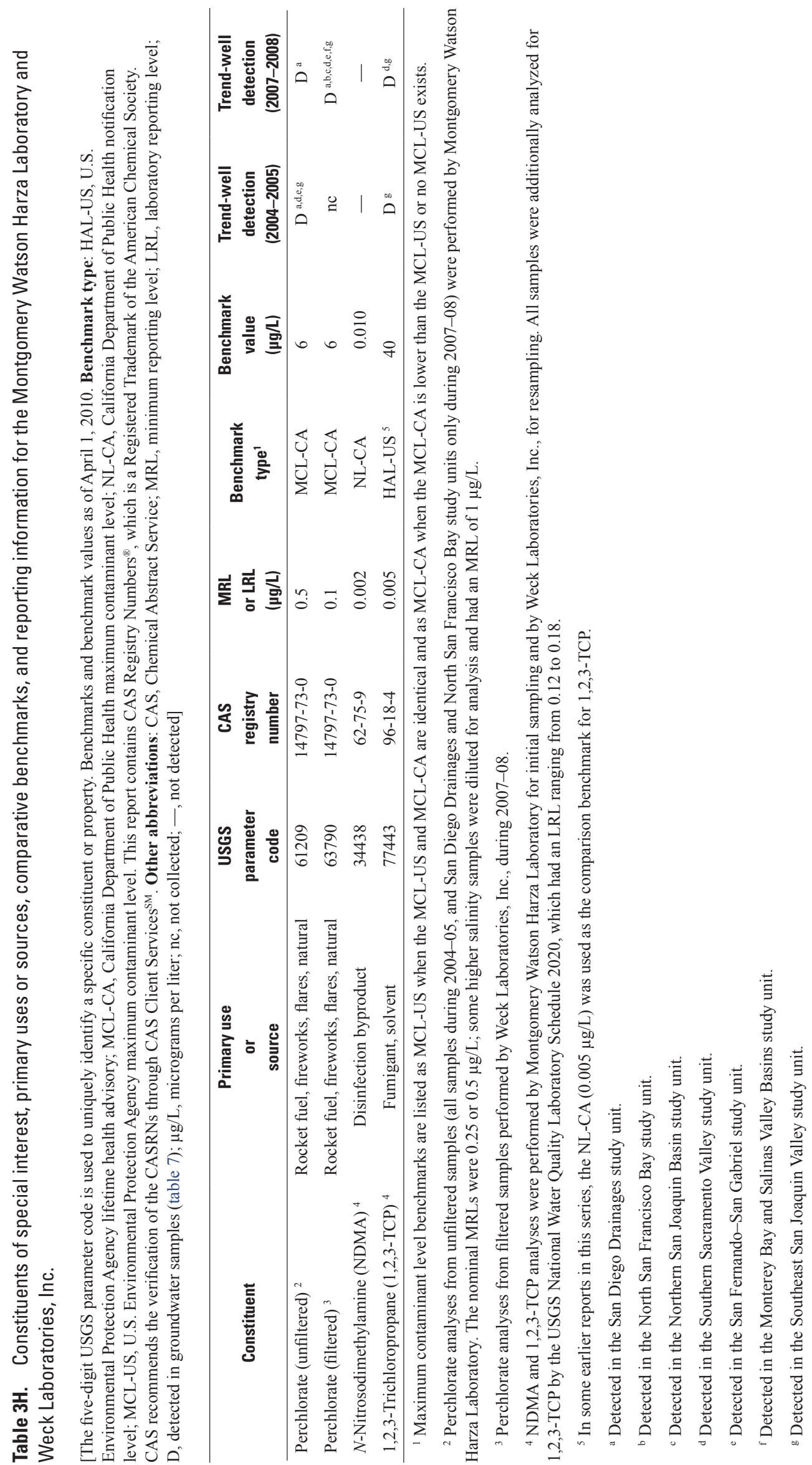


Table 3I. Isotopic and radioactive constituents, comparative benchmarks, and reporting information for laboratories.

[The five-digit USGS parameter code is used to uniquely identify a specific constituent or property. Stable isotope ratios are reported in the standard delta notation $(\delta)$, the ratio of a heavier isotope to more common lighter isotope of that element, relative to a standard reference material. Benchmark type and value for tritium were in effect during both sampling periods and continue to be in effect (July 2012). Benchmark type: MCL-CA, California Department of Public Health maximum contaminant level; MCL-US, U.S. Environmental Protection Agency maximum contaminant level. This report contains CAS Registry Numbers ${ }^{\circledR}$, which is a Registered Trademark of the American Chemical Society. CAS recommends the verification of the CASRNs through CAS Client Services $^{\mathrm{SM}}$. Other abbreviations: CAS, Chemical Abstract Service; MRL, minimum reporting level; MU, method uncertainty; na, not available; $\mathrm{pCi} / \mathrm{L}$, picocuries per liter]

\begin{tabular}{|c|c|c|c|c|c|c|}
\hline Constituent & $\begin{array}{c}\text { USGS } \\
\text { parameter } \\
\text { code }\end{array}$ & $\begin{array}{l}\text { CAS } \\
\text { registry } \\
\text { number }\end{array}$ & $\begin{array}{c}\text { Reporting } \\
\text { level } \\
\text { type }\end{array}$ & $\begin{array}{c}\text { Reporting level } \\
\text { or uncertainty } \\
\text { (range) }\end{array}$ & $\begin{array}{c}\text { Benchmark } \\
\text { type }^{1}\end{array}$ & $\begin{array}{c}\text { Benchmark } \\
\text { value }\end{array}$ \\
\hline \multicolumn{7}{|l|}{ Stable isotope ratios (per mil) } \\
\hline$\delta^{2} \mathrm{H}$ of water ${ }^{2}$ & $82082^{4}$ & na & MU & 2 & na & na \\
\hline$\delta^{18} \mathrm{O}$ of water ${ }^{2}$ & $82085^{4}$ & na & MU & 0.20 & na & na \\
\hline$\delta^{13} \mathrm{C}$ of dissolved carbonates ${ }^{3}$ & $82081^{4}$ & na & 1 sigma & 0.05 & na & na \\
\hline \multicolumn{7}{|c|}{ Radioactive constituents (percent modern) } \\
\hline Carbon-14 ${ }^{5}$ & 49933 & $14762-75-5$ & 1 sigma & $(0.0015-0.002)$ & na & na \\
\hline \multicolumn{7}{|l|}{ Radioactive constituents (pCi/L) } \\
\hline Tritium $^{6}$ & 07000 & $10028-17-8$ & MRL & $(0.3-1)$ & MCL-CA & 20,000 \\
\hline
\end{tabular}

${ }^{1}$ Maximum contaminant level benchmarks are listed as MCL-US when the MCL-US and MCL-CA are identical and as MCL-CA when the MCL-CA is lower than the MCL-US or no MCL-US exists.

${ }^{2}$ USGS Stable Isotope Laboratory, Reston, Virginia.

${ }^{3}$ University of Waterloo (contract laboratory).

${ }^{4}$ Parameters 82081,82082 , and 82085 are isotopes that are inherent constituents of the substance being measured. Parameter 82081 was not detected in Southeast San Joaquin Valley study unit wells during resampling in 2008 because those samples were not analyzed for it.

${ }^{5}$ University of Arizona, Accelerator Mass Spectrometry Laboratory (contract laboratory).

${ }^{6}$ USGS Stable Isotope and Tritium Laboratory, Menlo Park, California. 
量

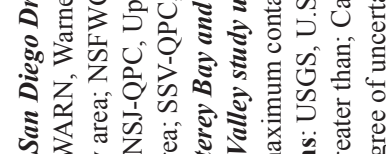

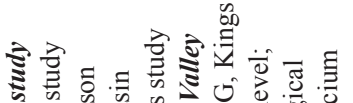

औ

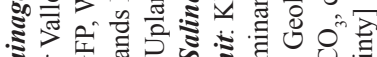

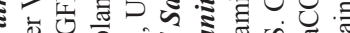

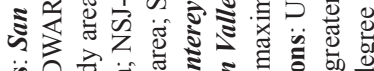

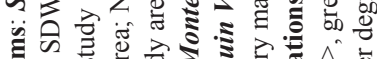

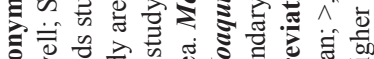

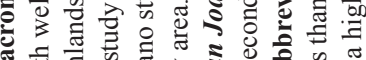

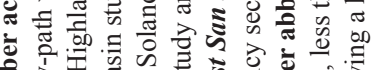

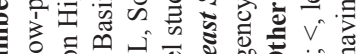

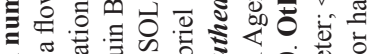

흘

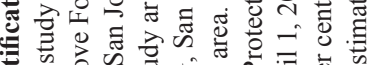

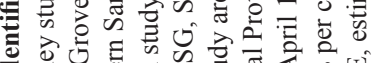

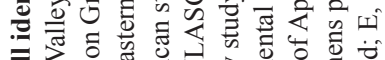

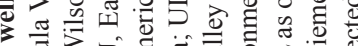

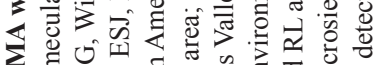

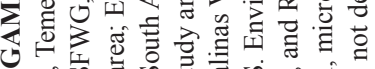

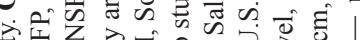

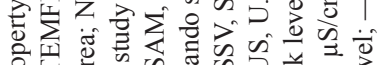

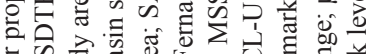

के की

言

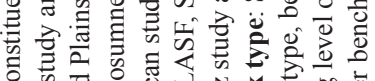

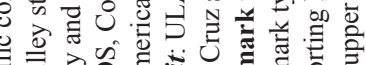

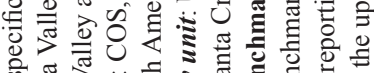

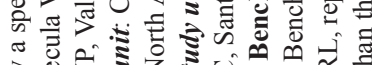

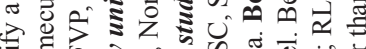

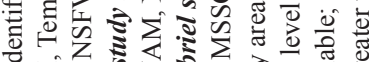

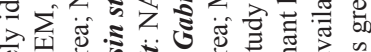

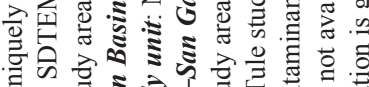

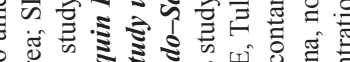

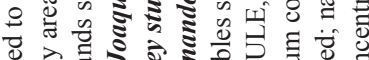

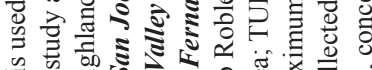

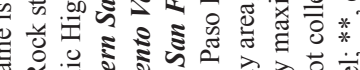

要

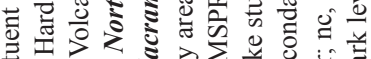

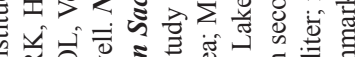

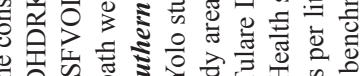

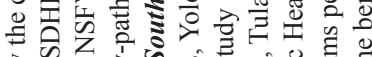

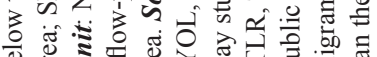

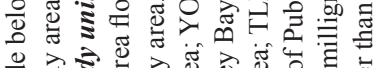

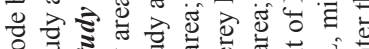

等

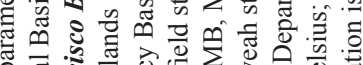

2. बु

क $ई$

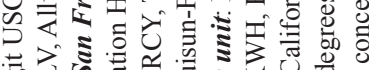

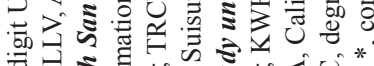

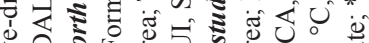

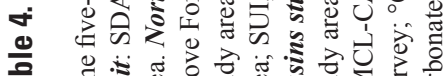

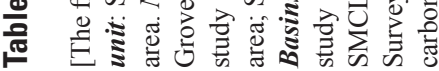

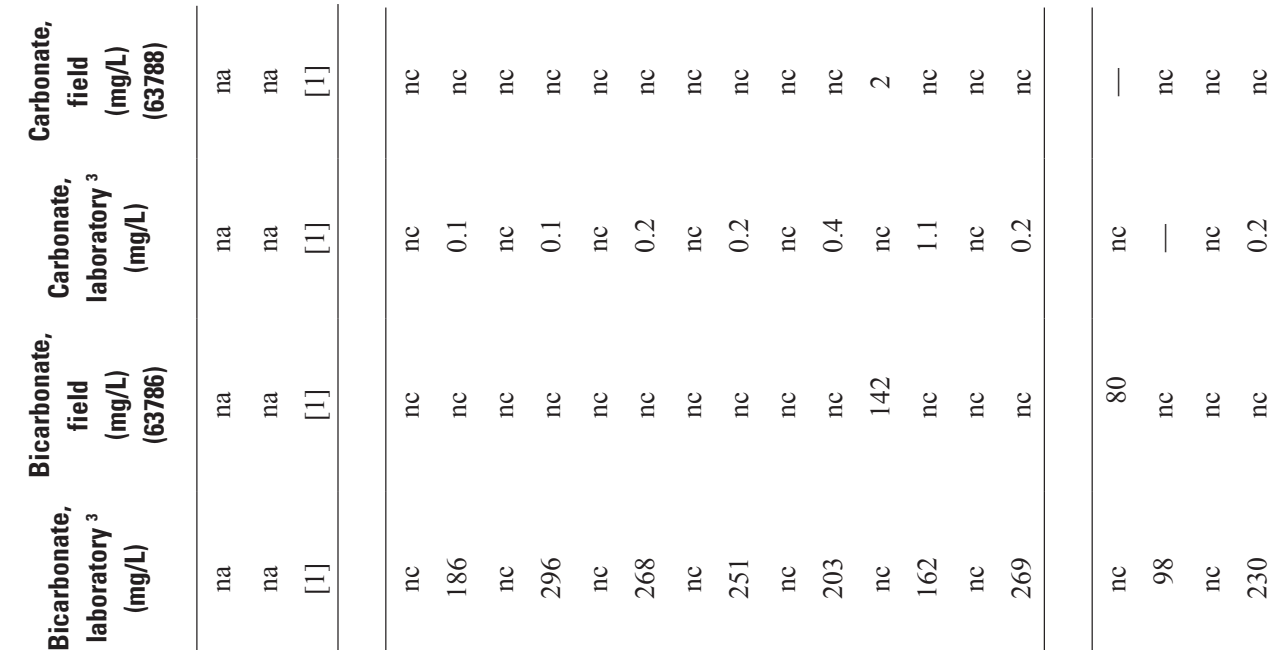

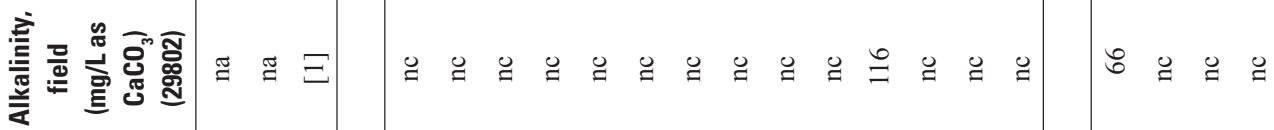

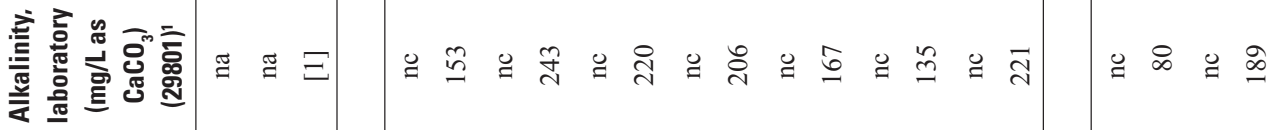

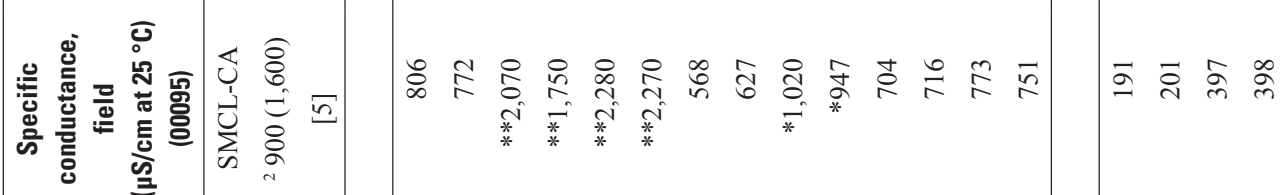

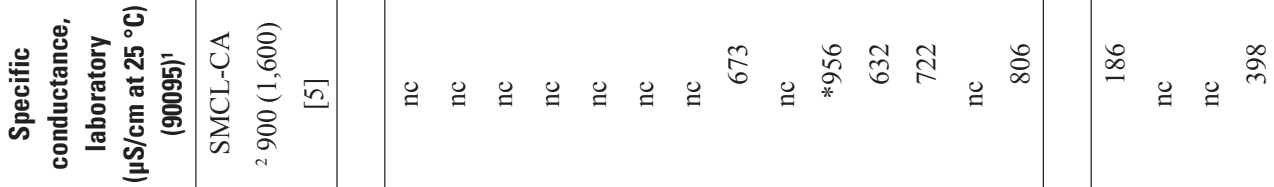

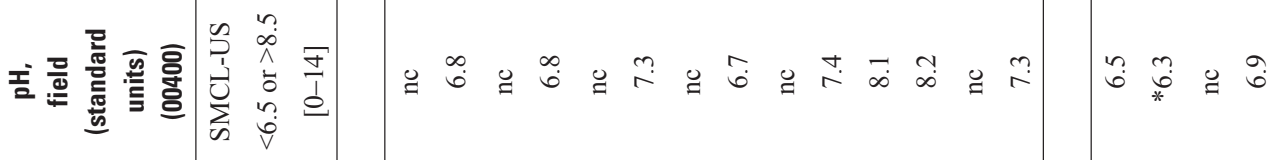

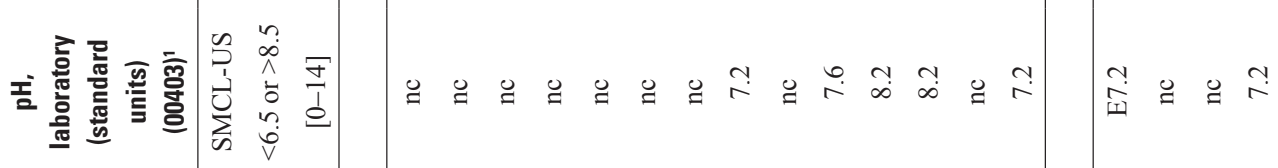

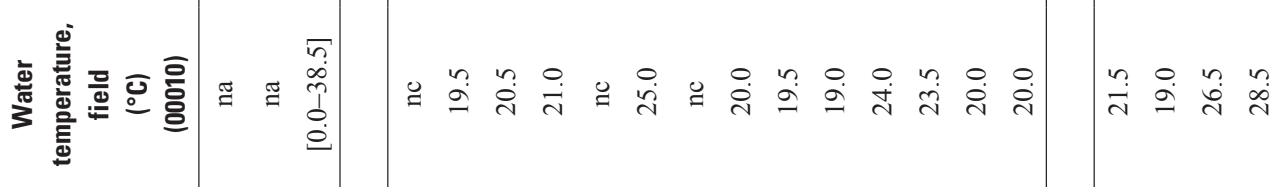

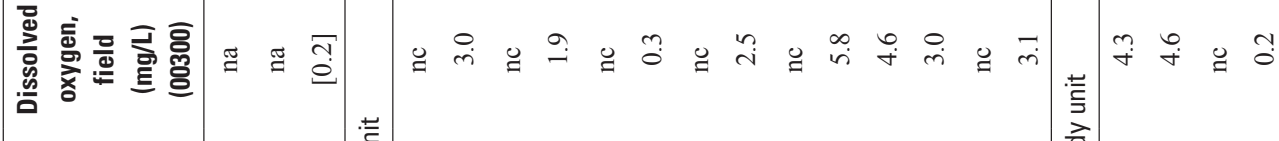

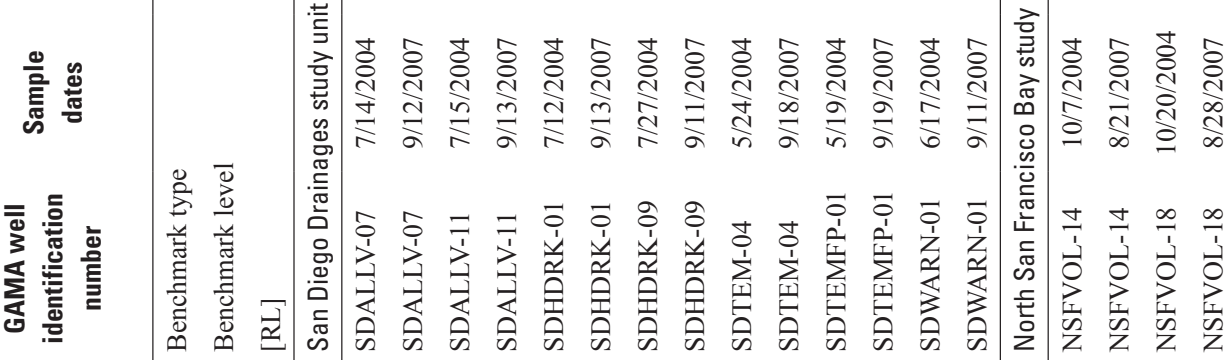



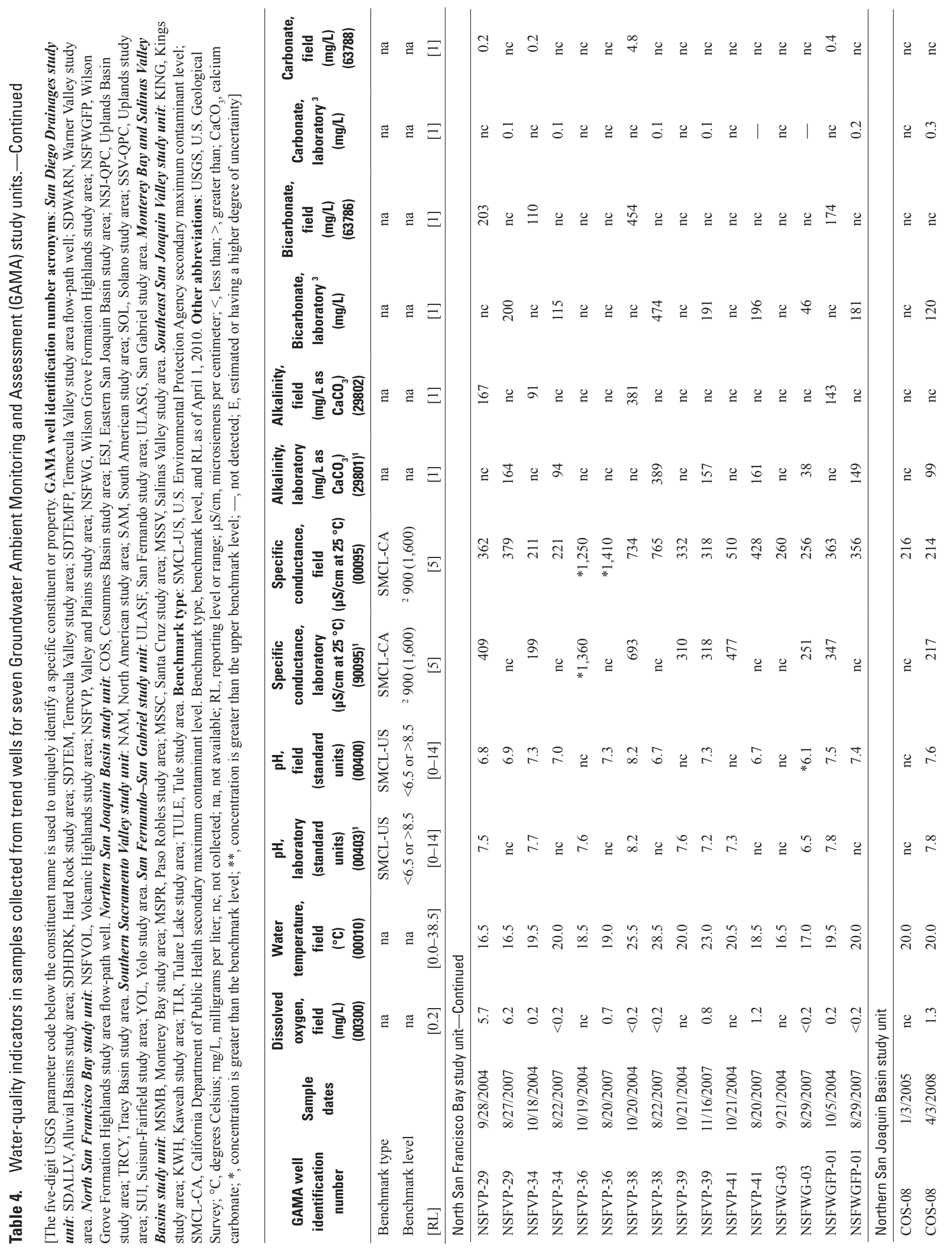
Tables

๖.

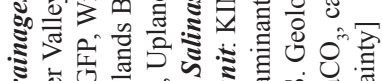

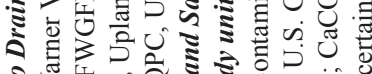

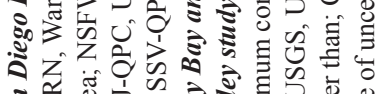

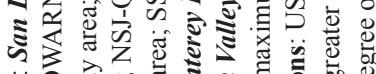

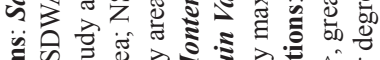

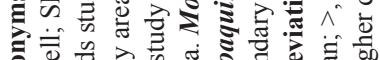

क्ष

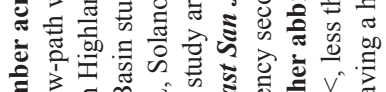

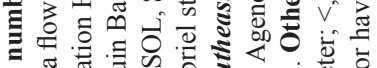

ప。ँ

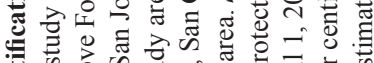

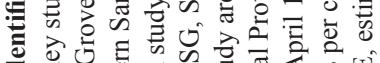

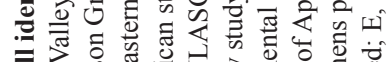

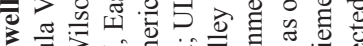

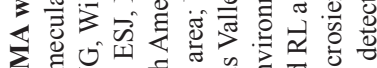

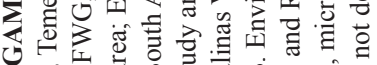

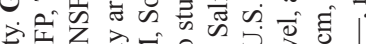

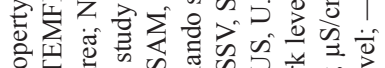

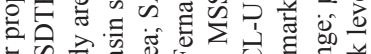

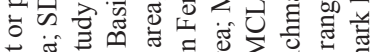

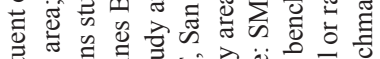

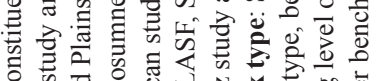

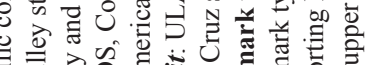

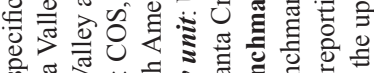

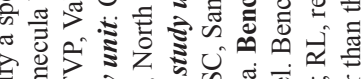

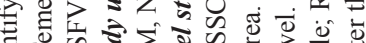

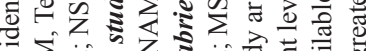

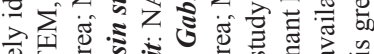

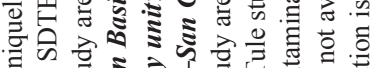

ชే

원

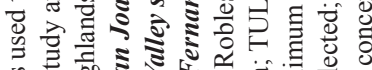

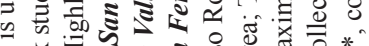

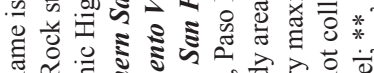

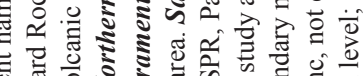

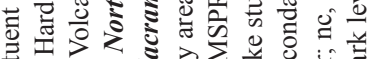

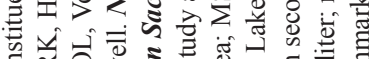

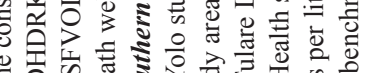

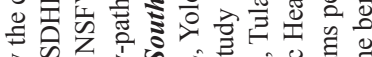

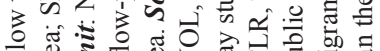

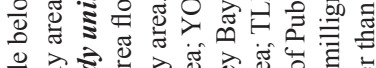

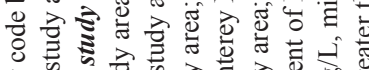

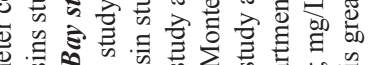

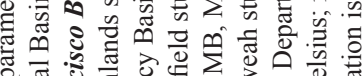

․

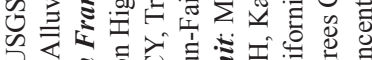

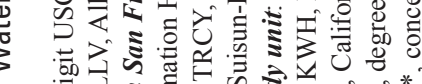

च

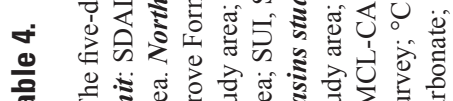

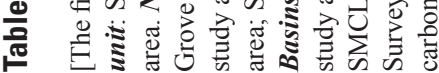

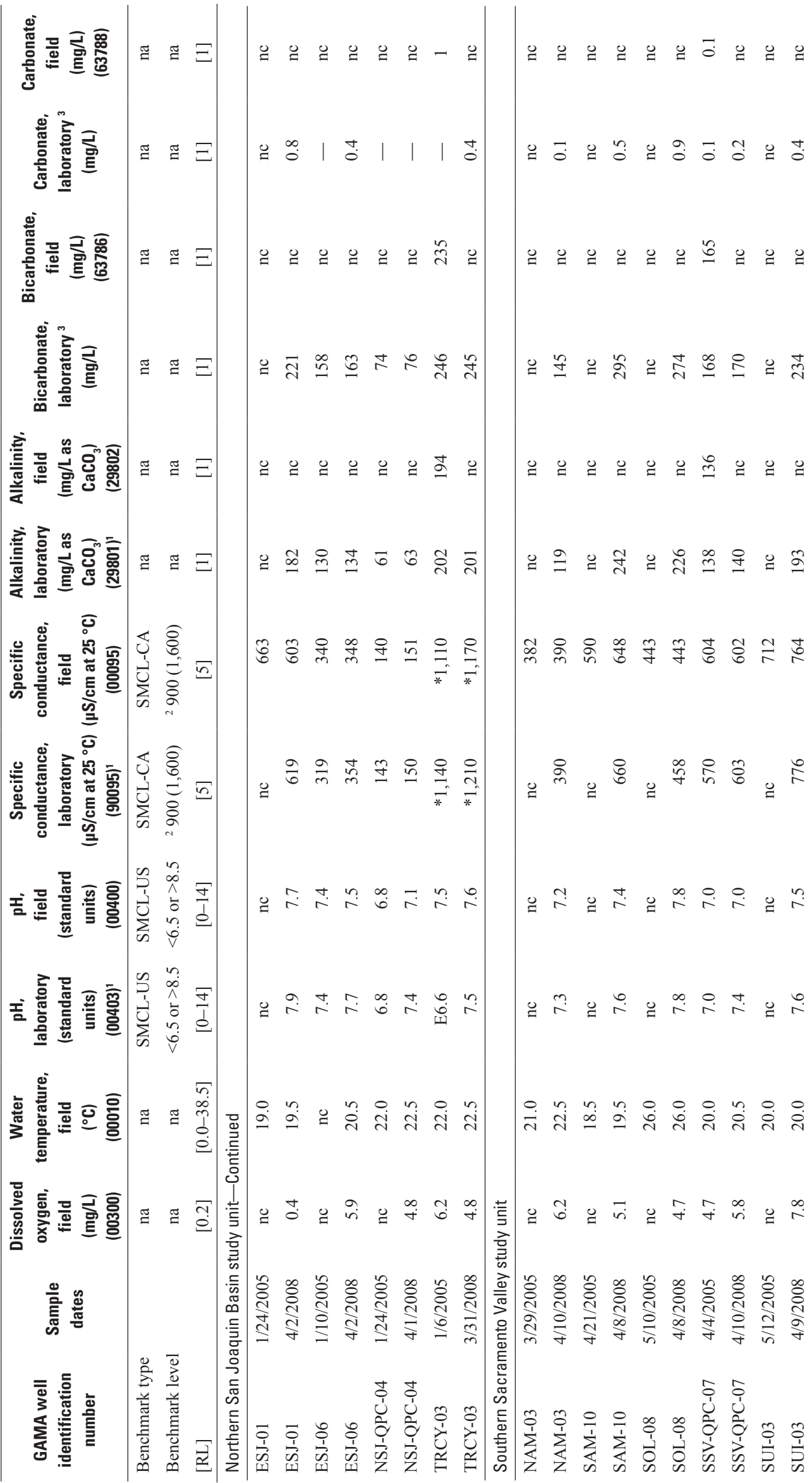




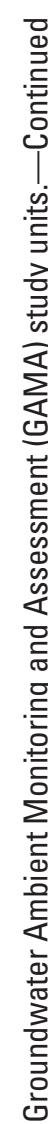

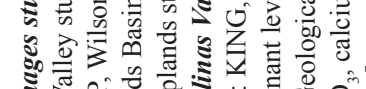

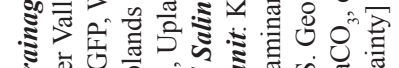

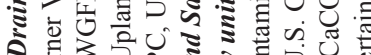

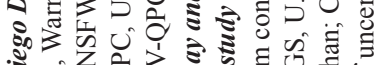

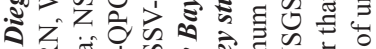

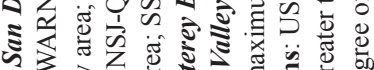

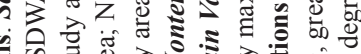

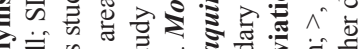

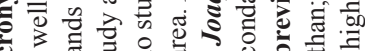

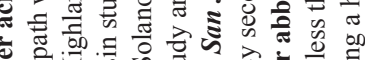

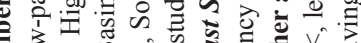

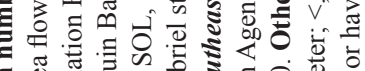

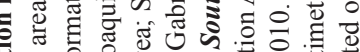

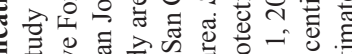

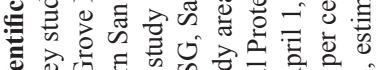

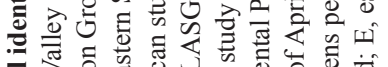

言

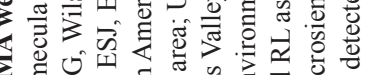

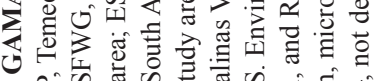

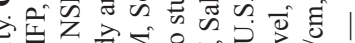

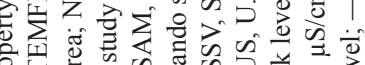

o ch on

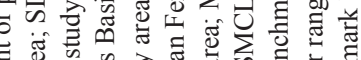

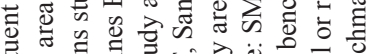

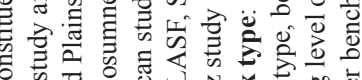

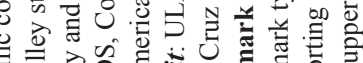

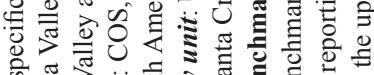

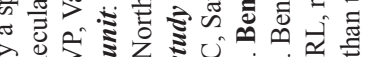

在

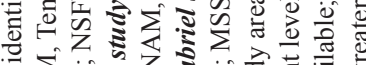

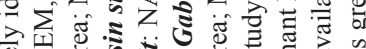

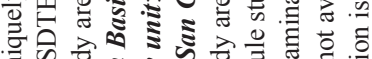

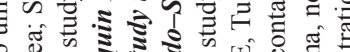

은

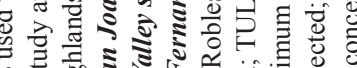

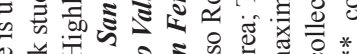

눙

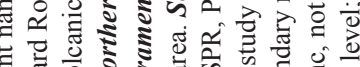

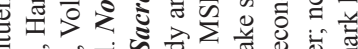

然

잉

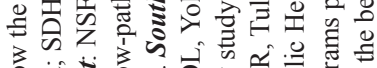

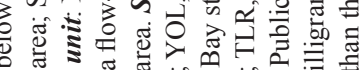

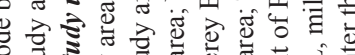

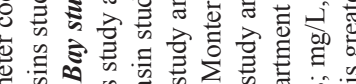

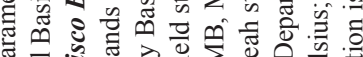

. बత]

क

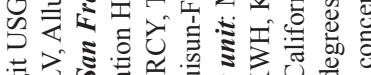

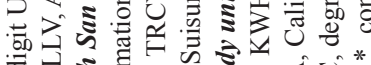

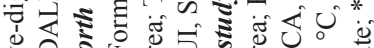

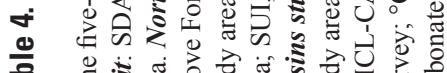

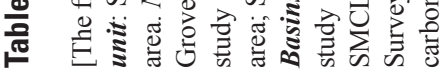

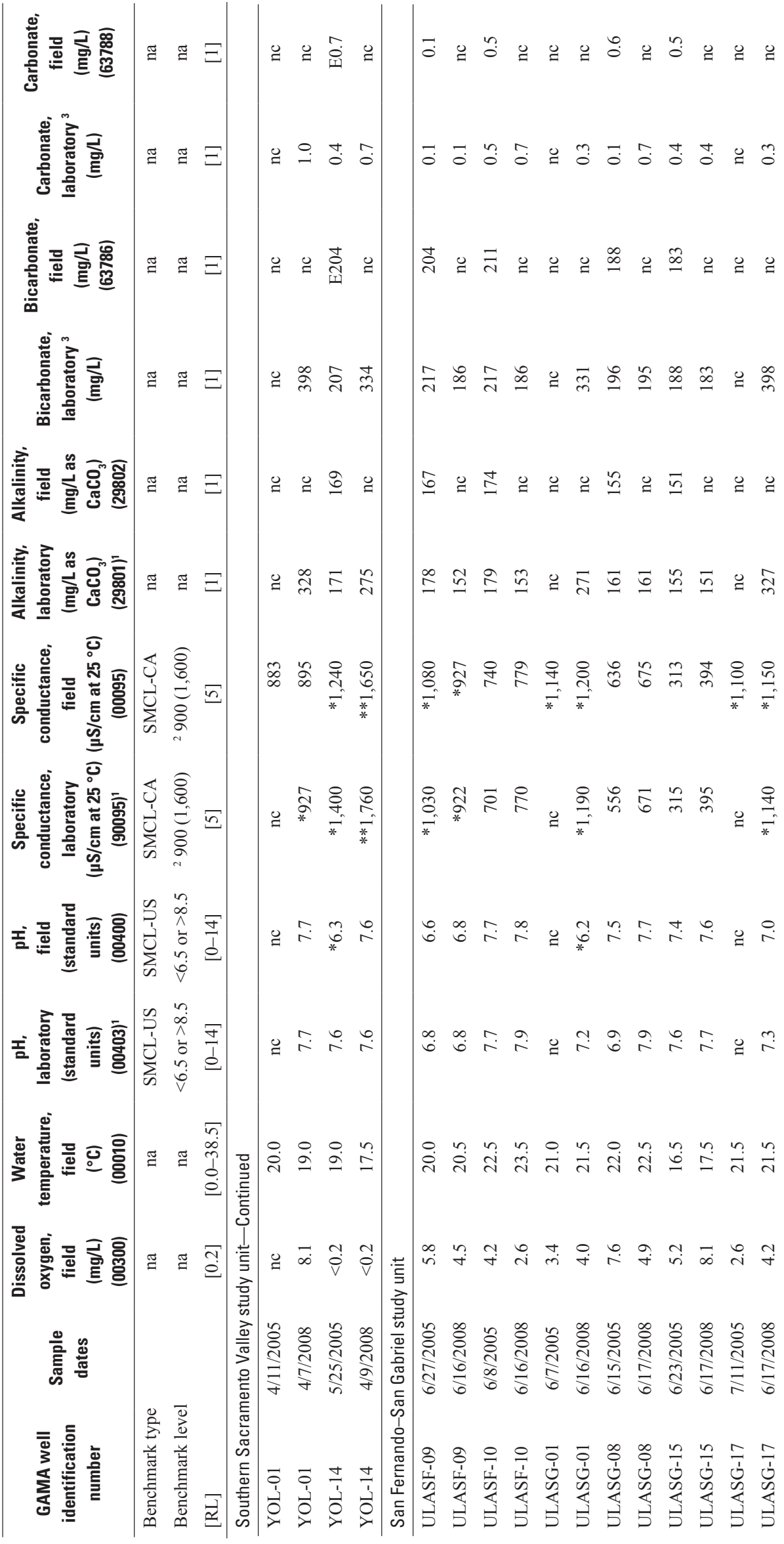


(

8000

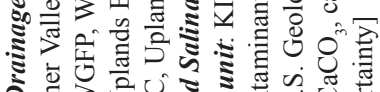

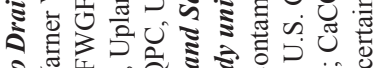

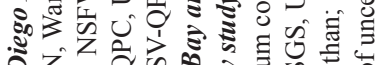

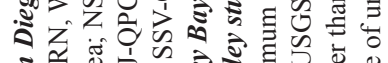

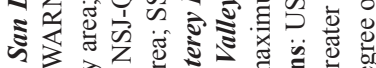

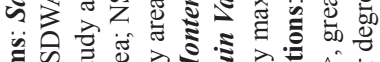

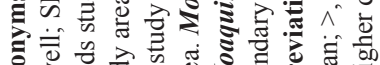

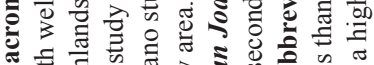

政击

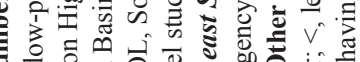

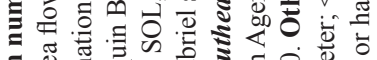
.

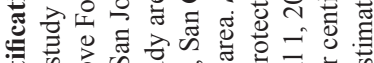

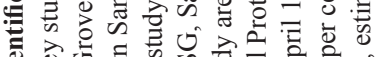

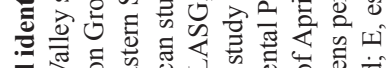

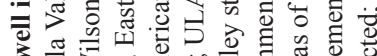

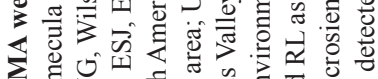

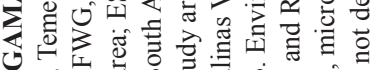
U

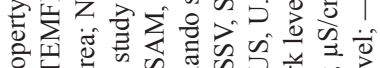

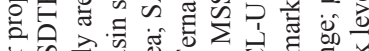

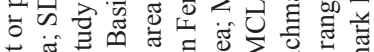

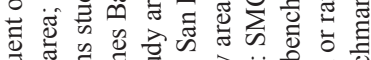

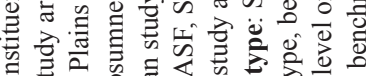

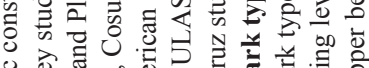

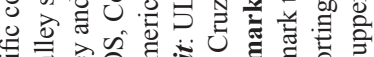

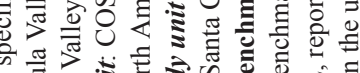
की 纪至

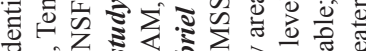

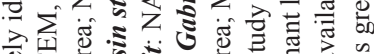

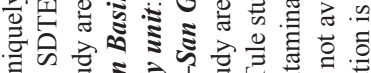
थं

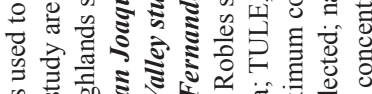
क क

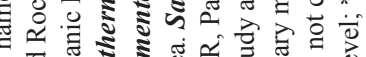

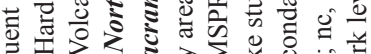

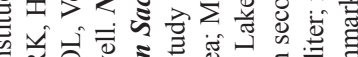

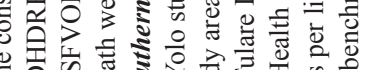

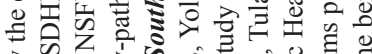

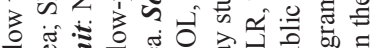

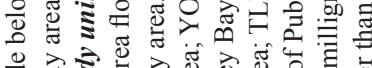

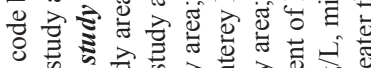

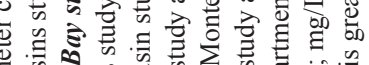

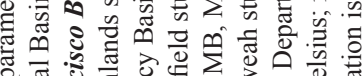

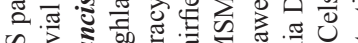

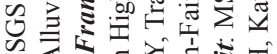

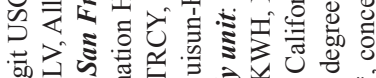

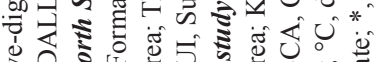

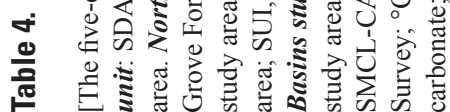

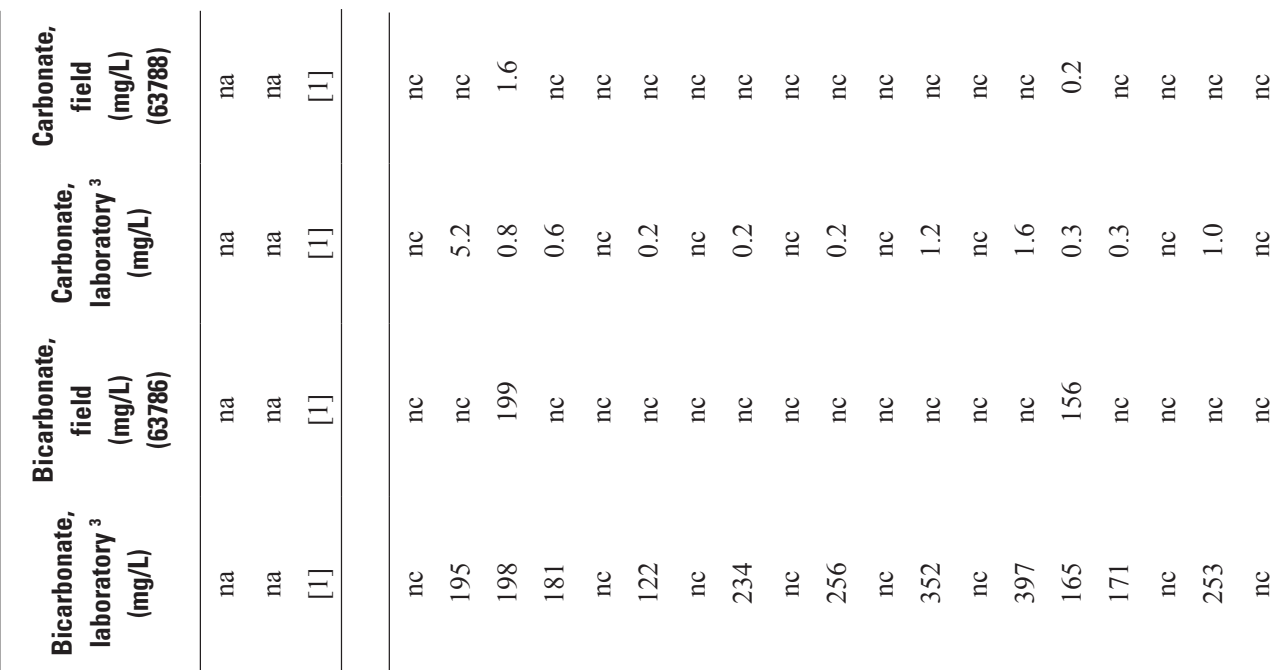

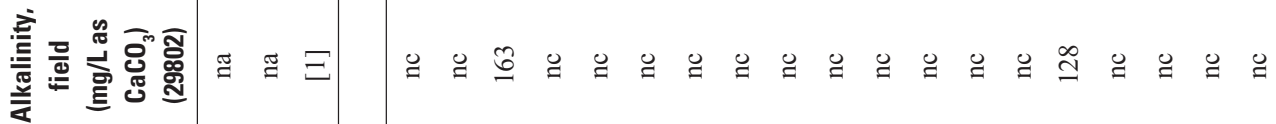

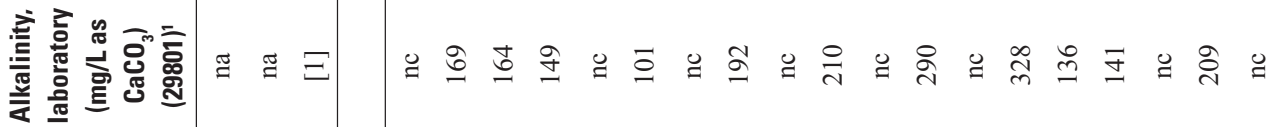

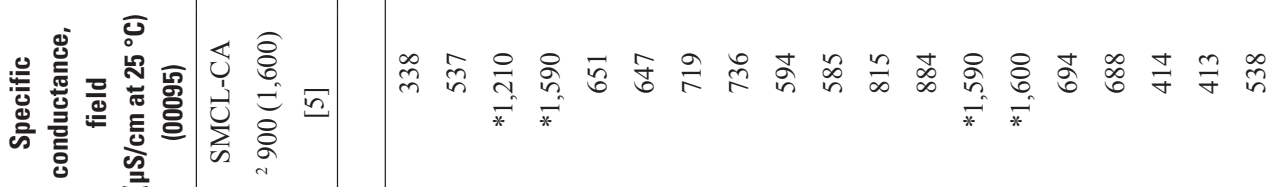

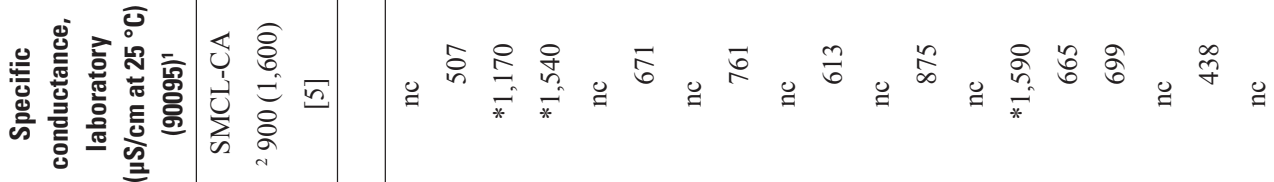

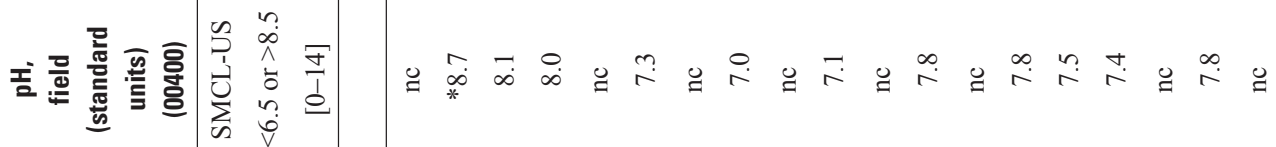

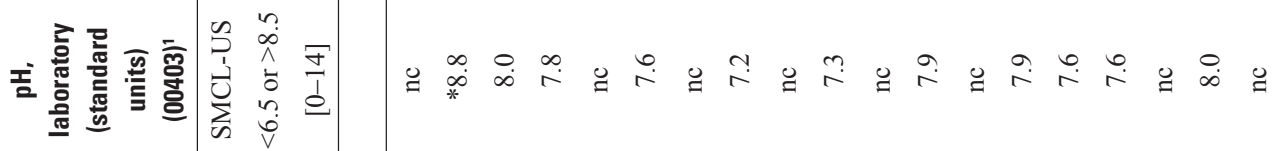

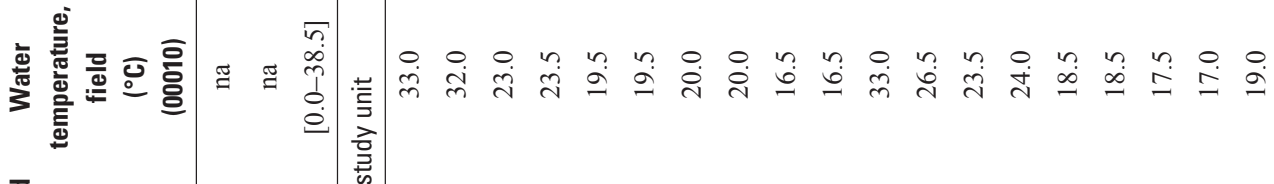
总

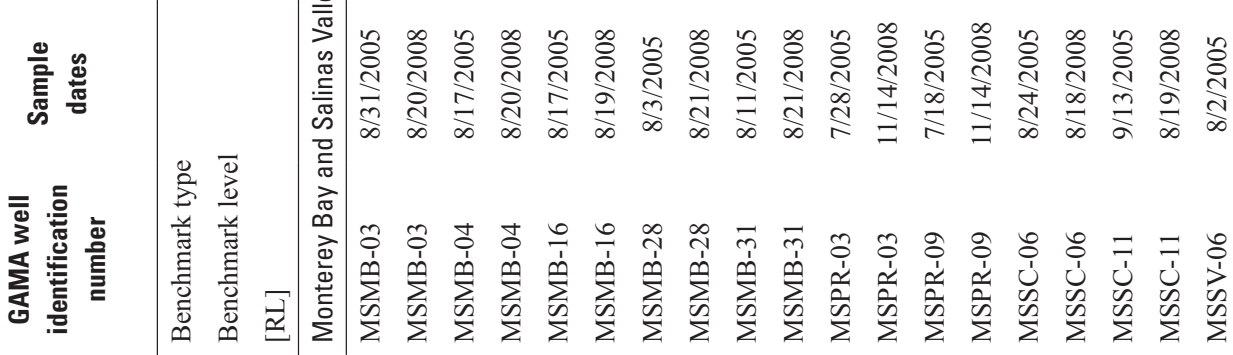



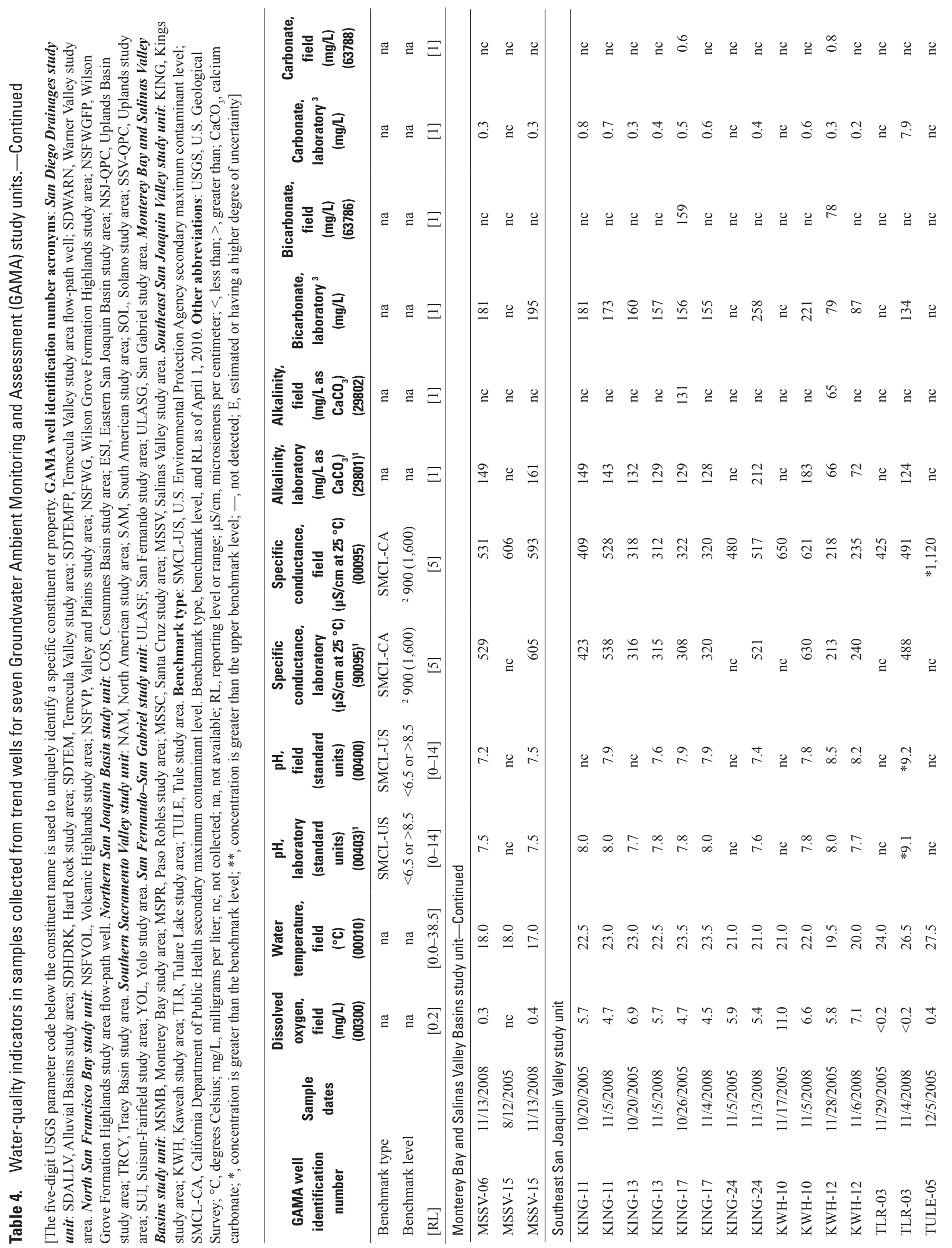


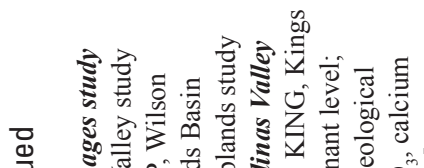

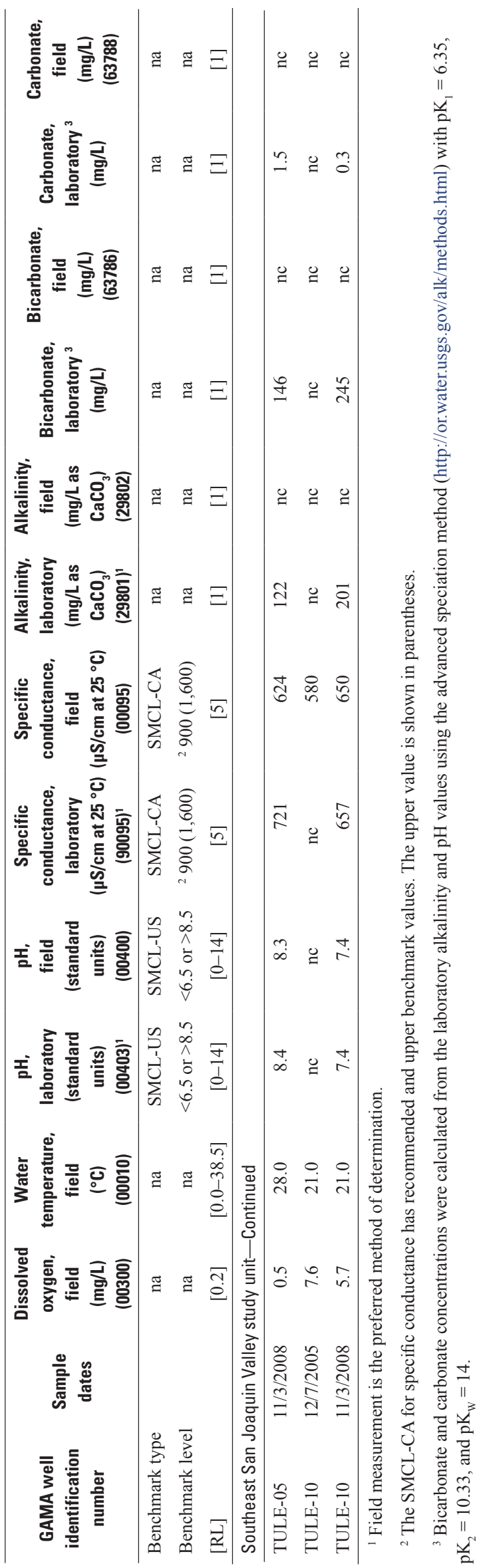



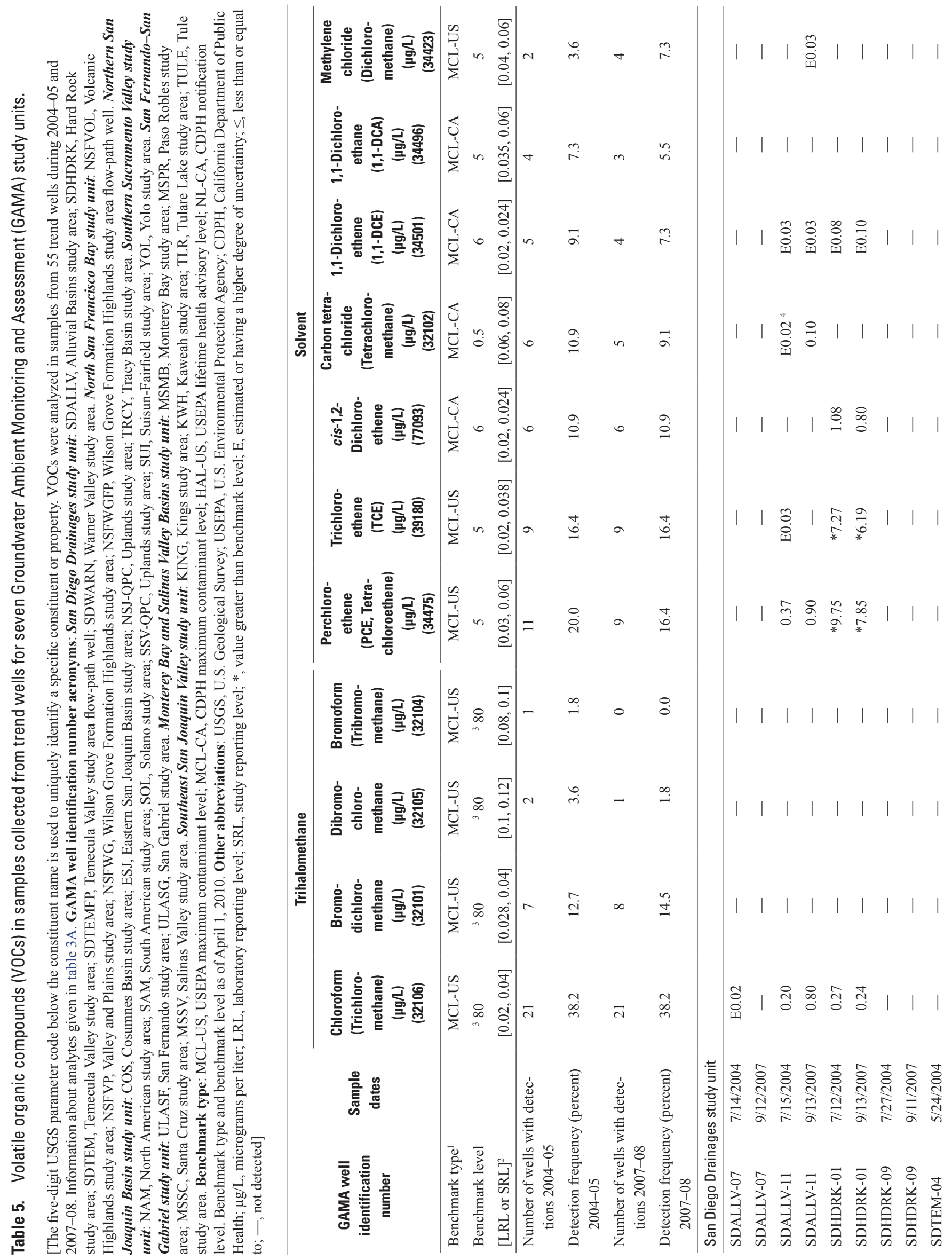


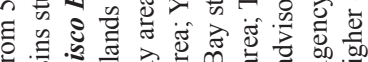

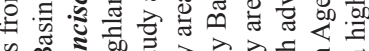

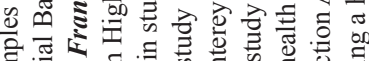

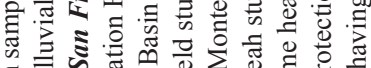

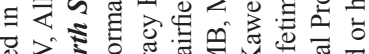

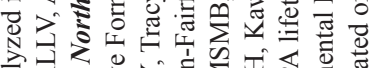

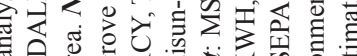

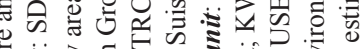

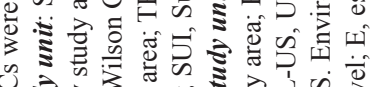

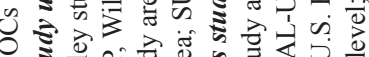

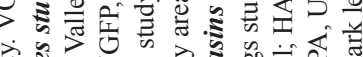

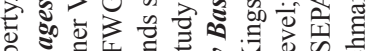

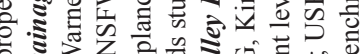

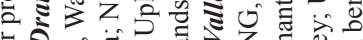

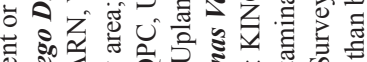

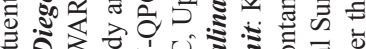

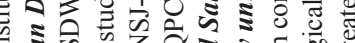

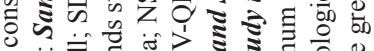

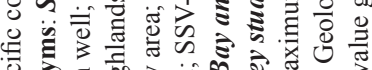

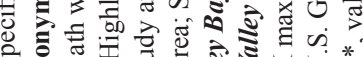
कर के के

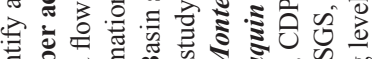
可

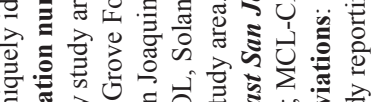

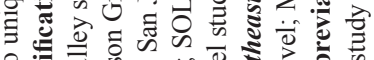
을

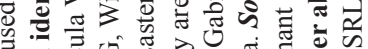

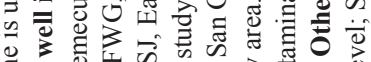

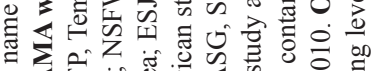

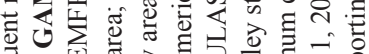

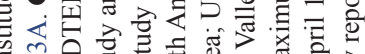
的击

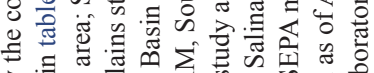

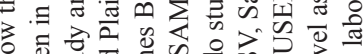

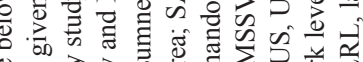

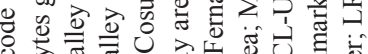

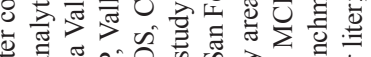

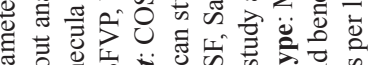

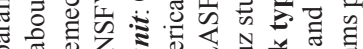
论

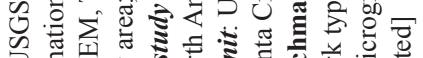

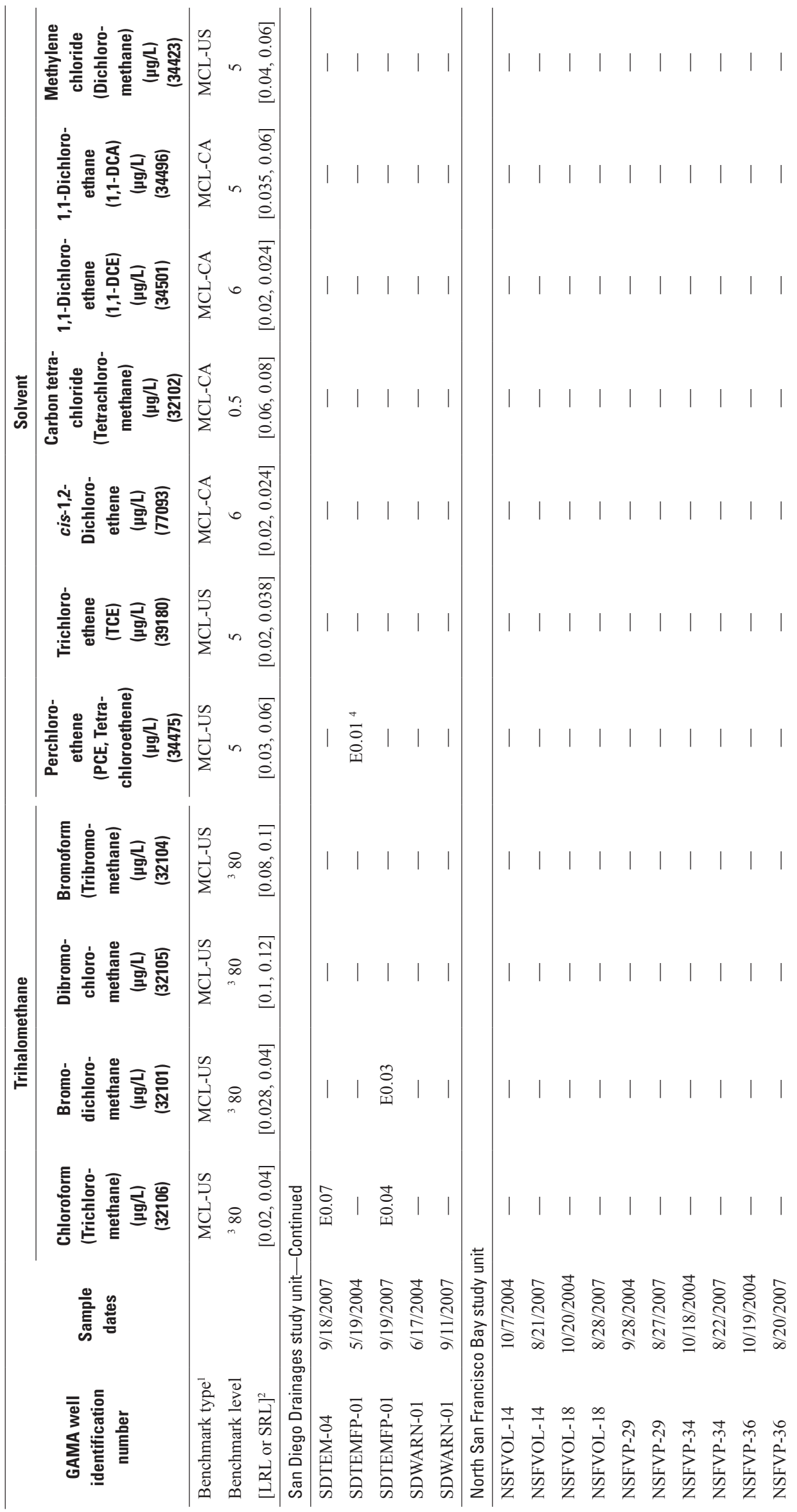



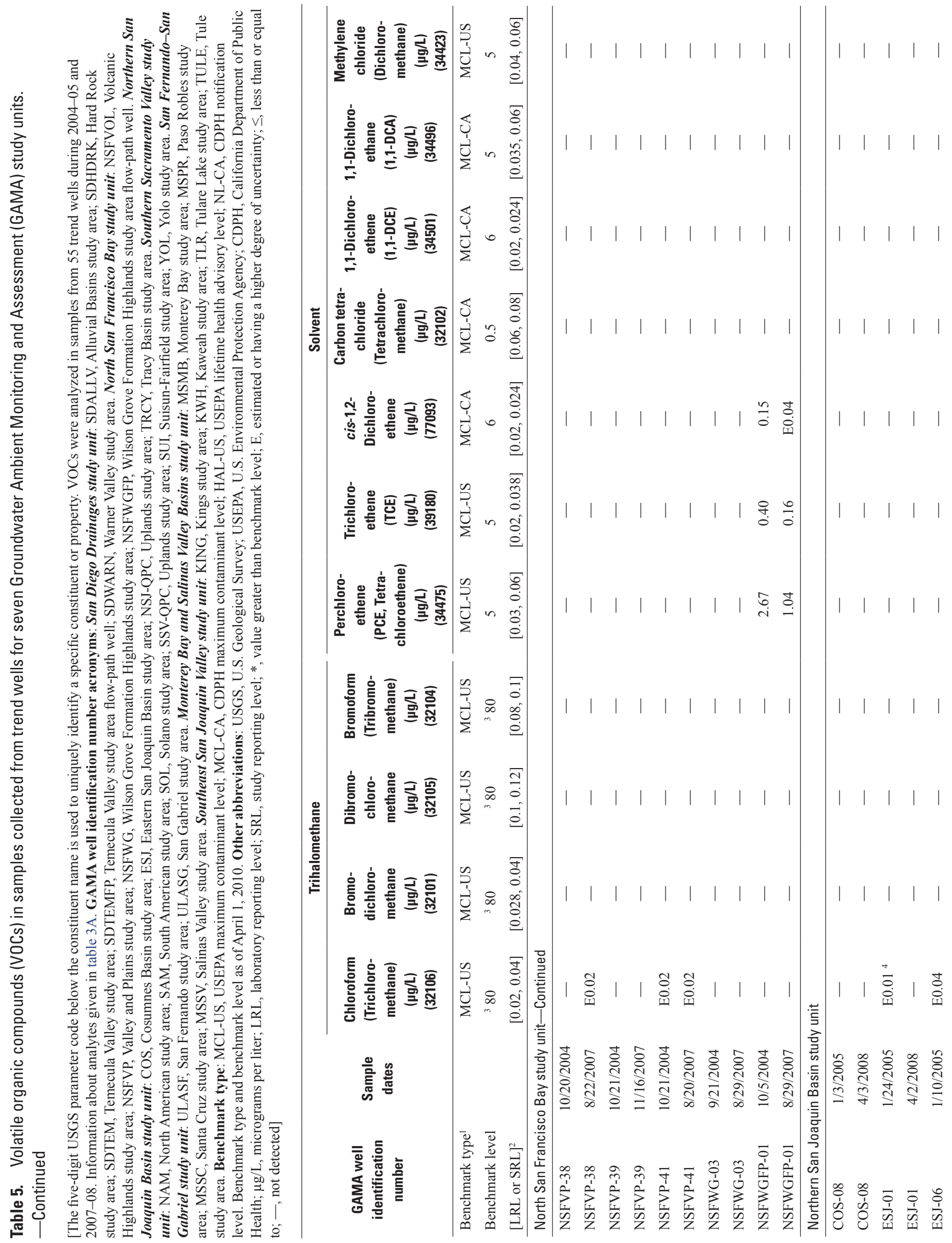


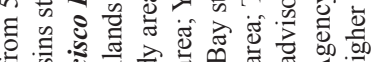

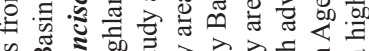

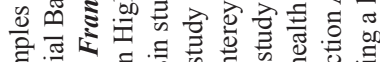

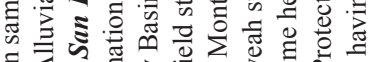

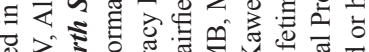

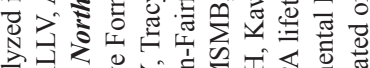

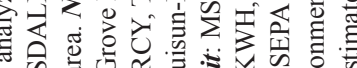
\% की

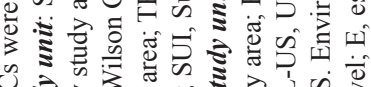

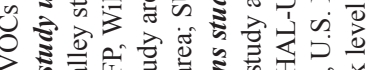

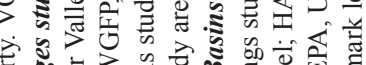

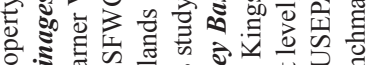

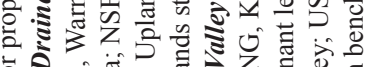

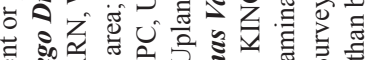

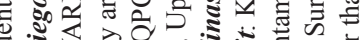

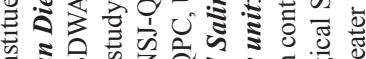

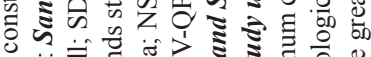

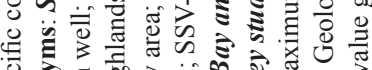

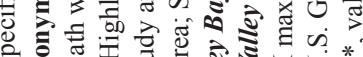
क के के

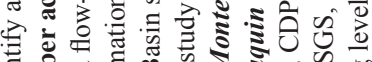
क्ष

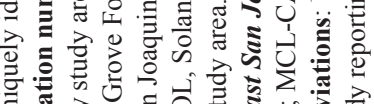

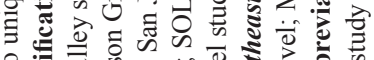
을

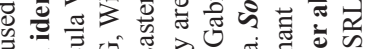

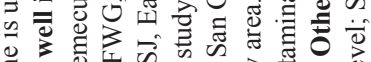

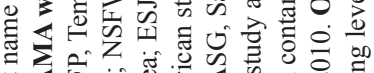

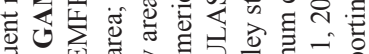

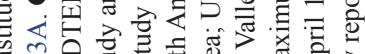
的击

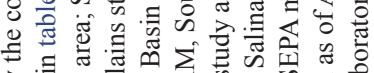

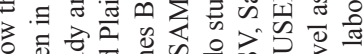

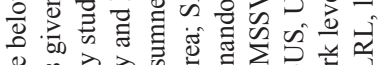

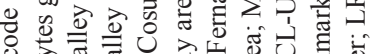

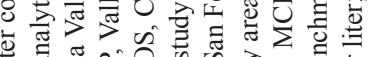

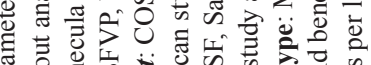

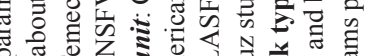

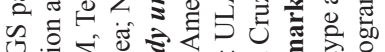

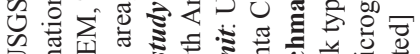

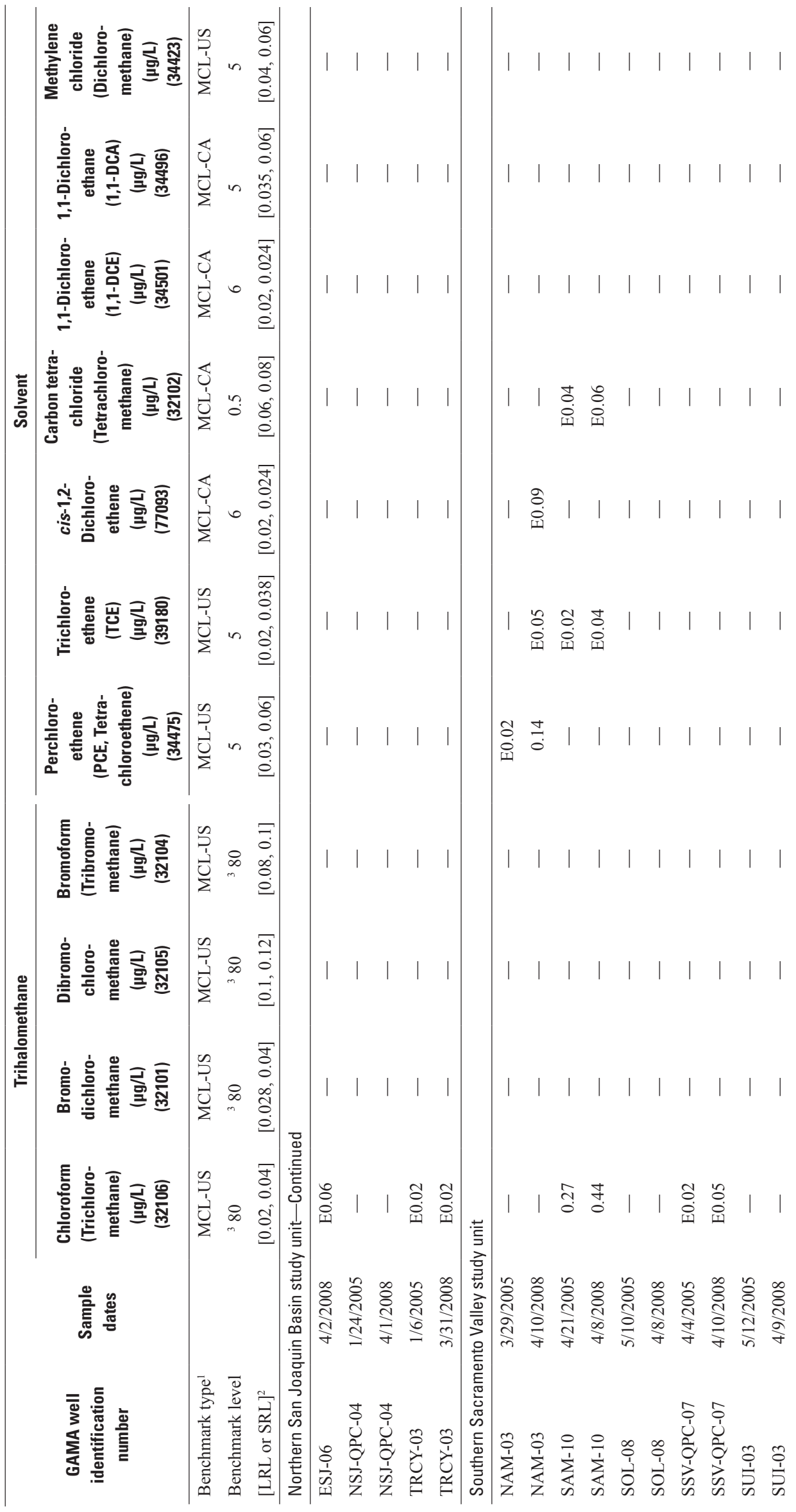




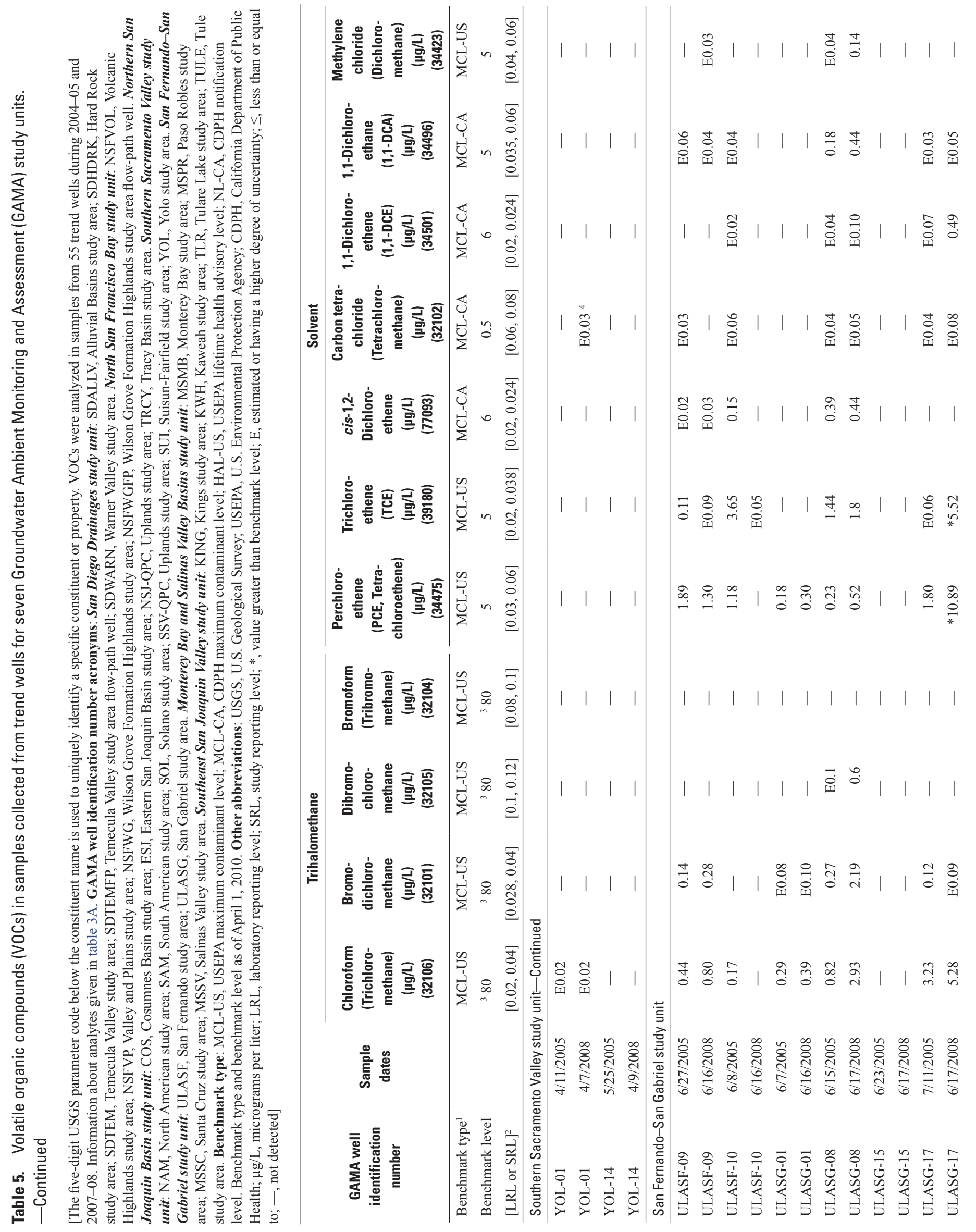



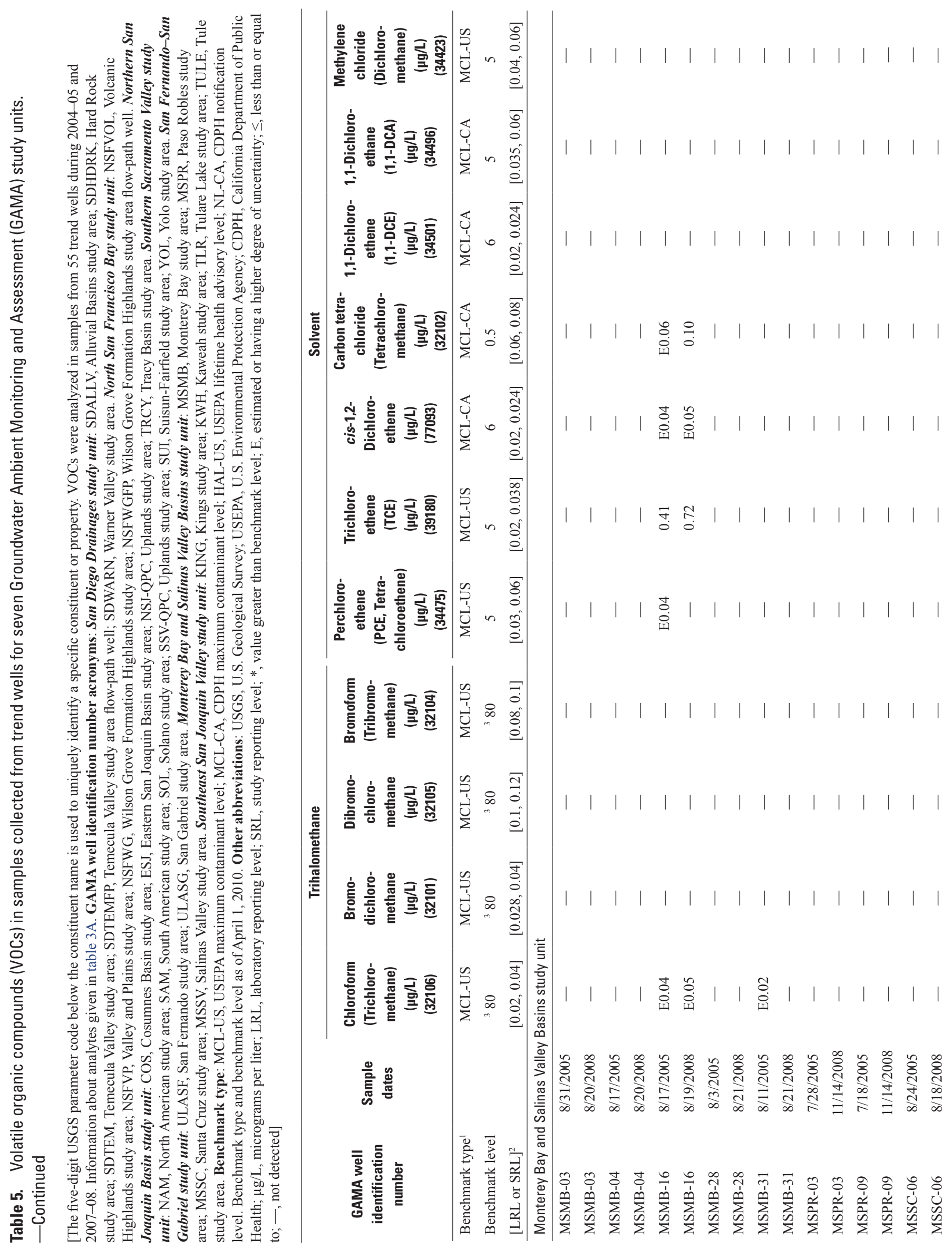

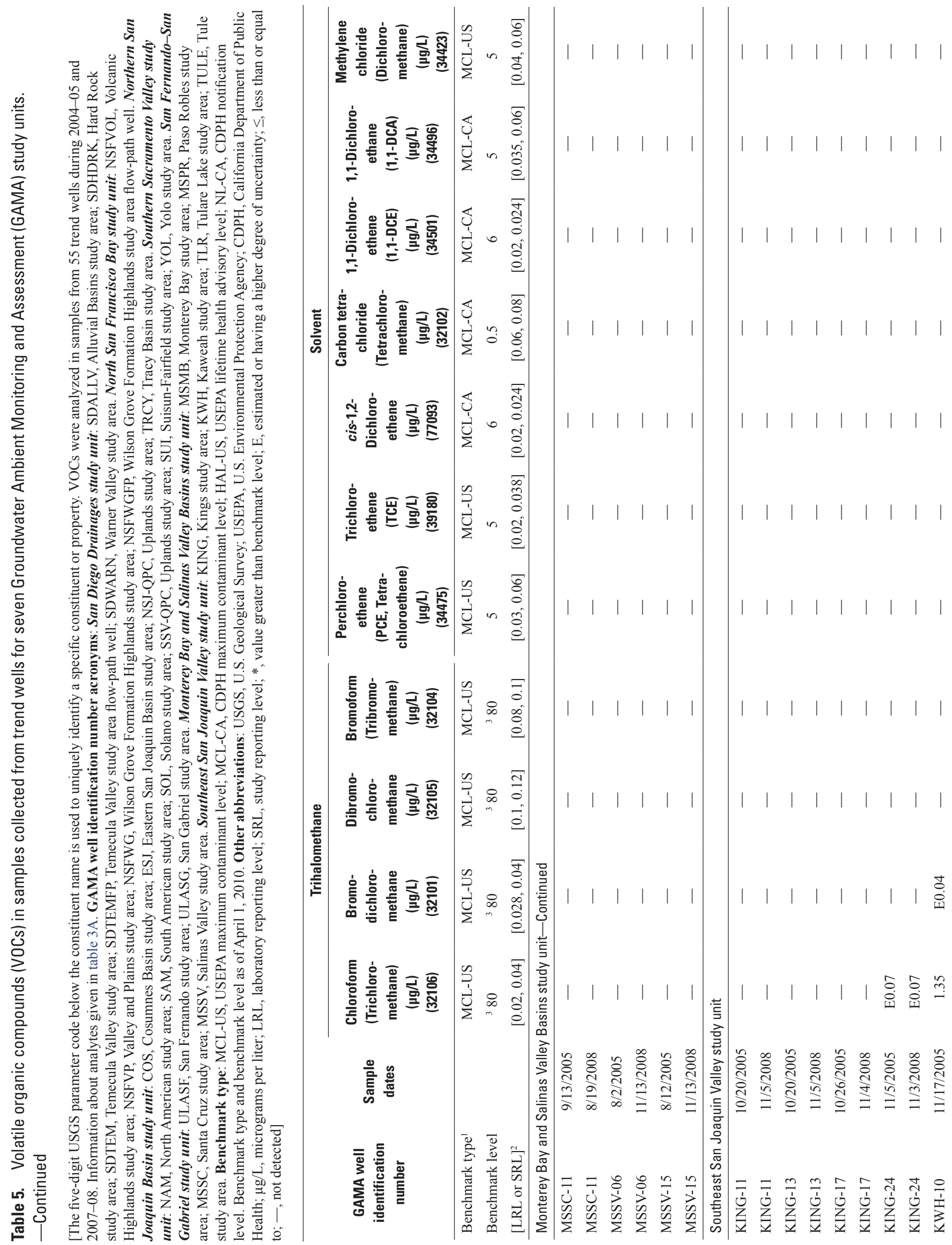

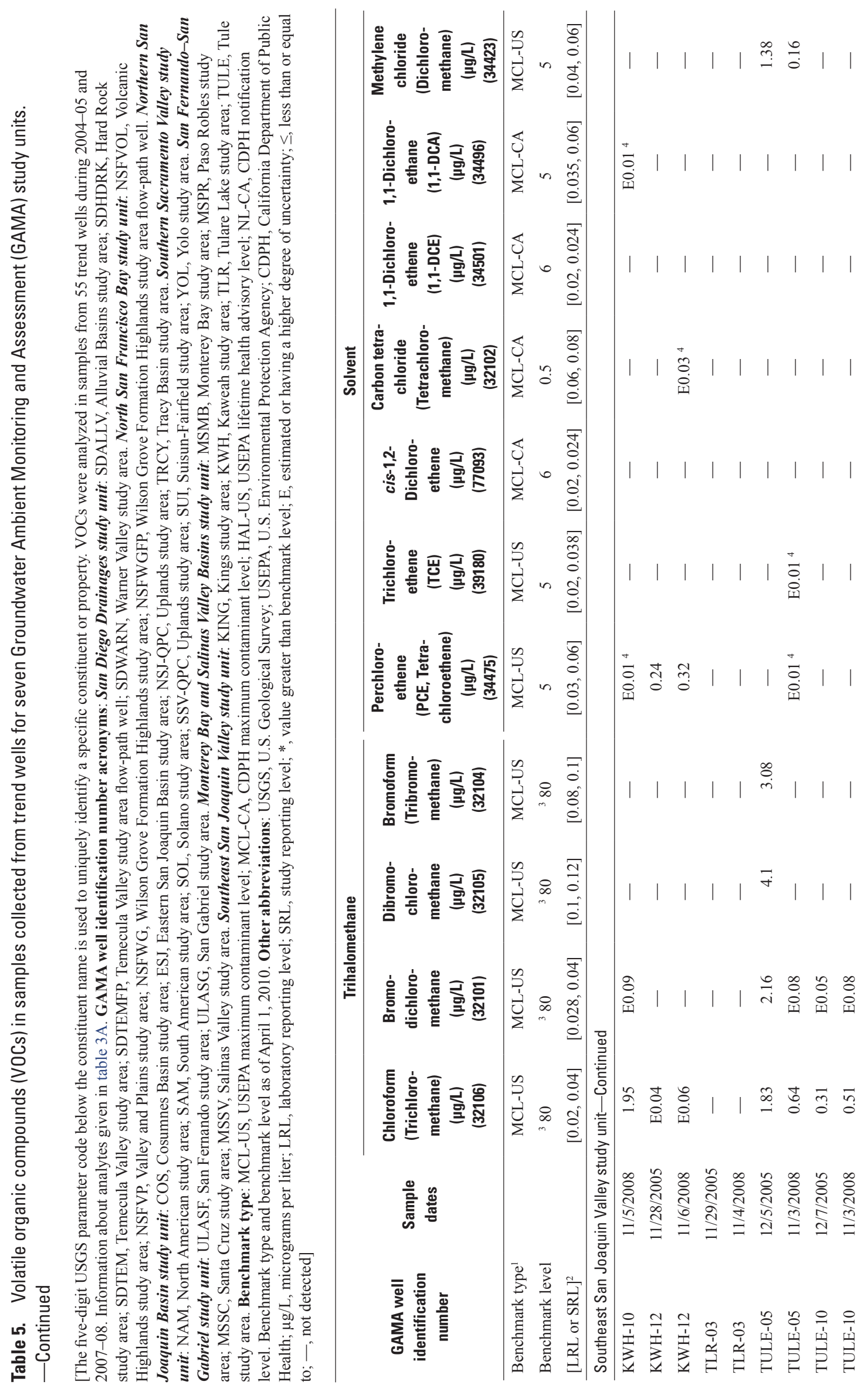


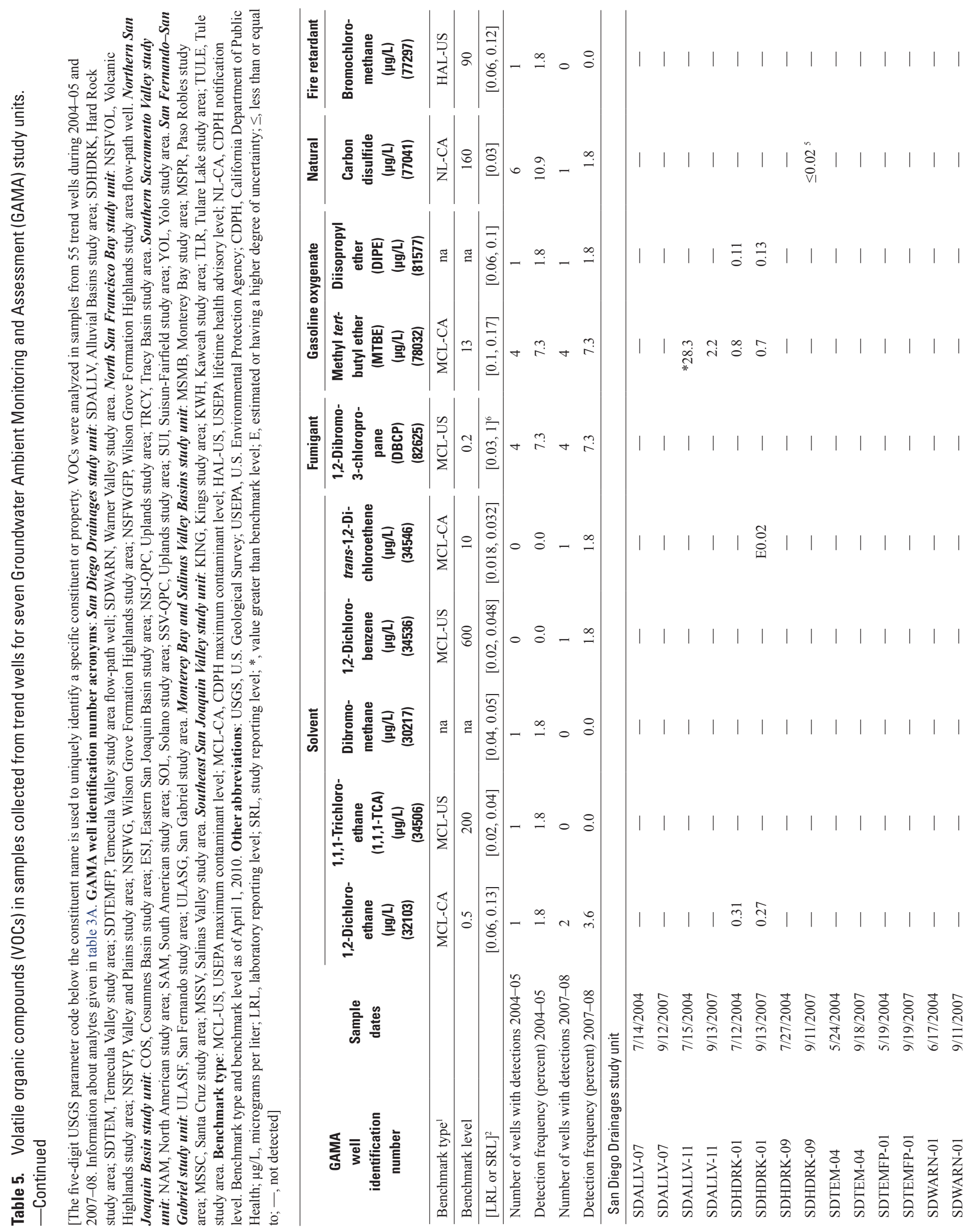




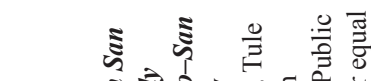

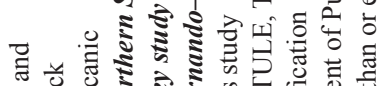

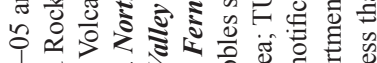

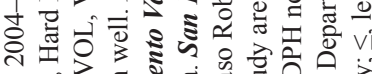
on 娄

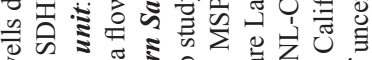

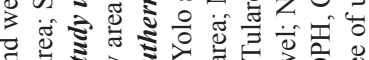

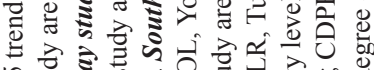

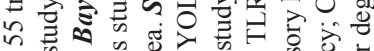

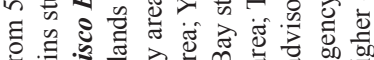

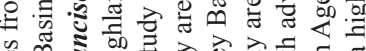

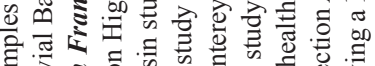

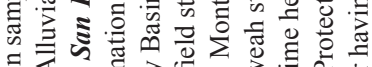
준 닐

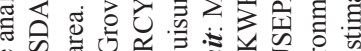

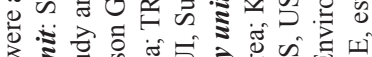

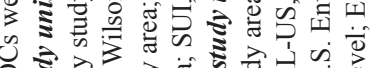
응

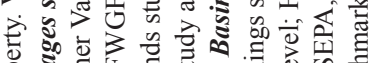

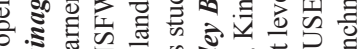

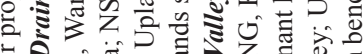

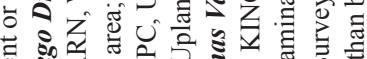

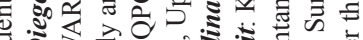

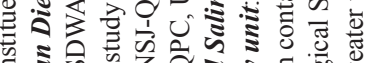

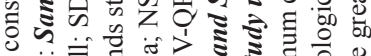

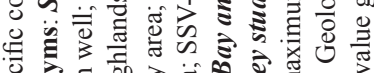

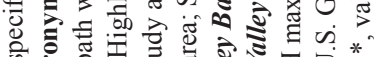
क ज

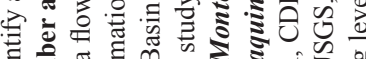

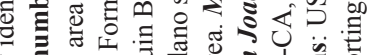

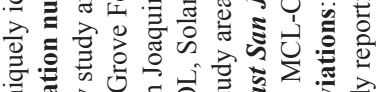

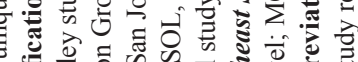

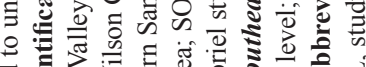

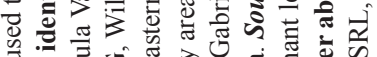

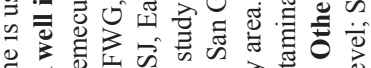

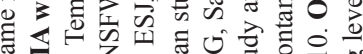

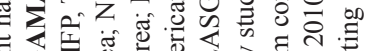

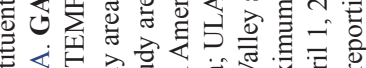

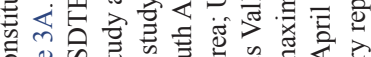

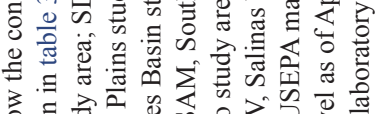
在

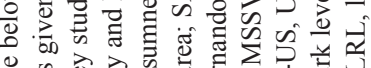

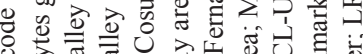

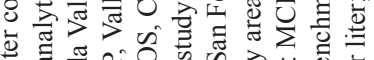

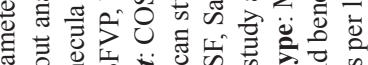

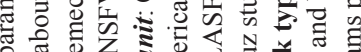

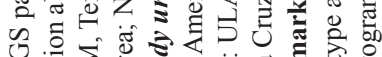

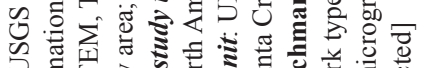

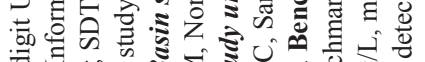

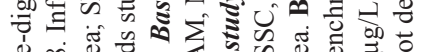

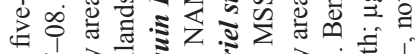

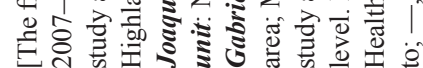
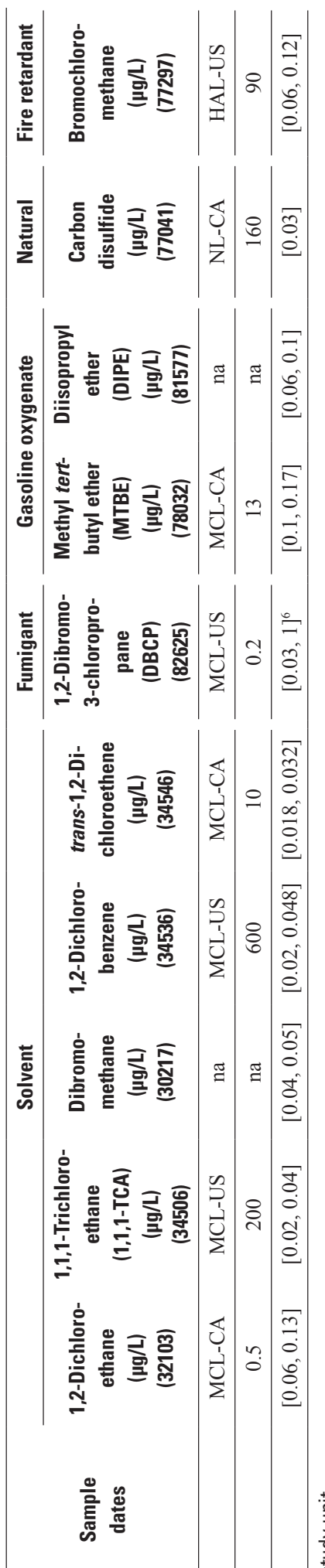

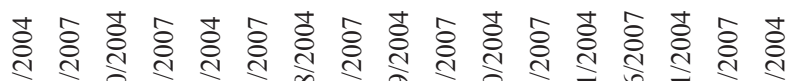

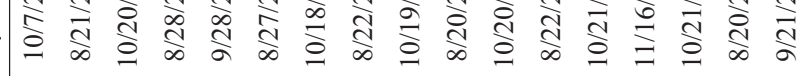

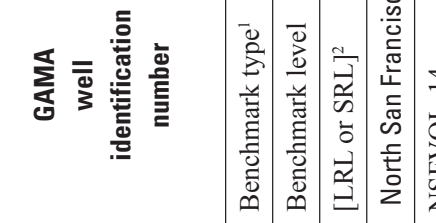

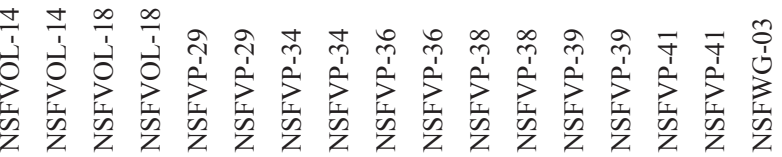




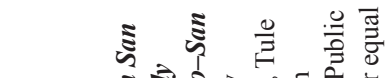
근

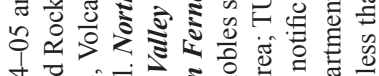

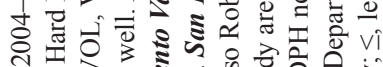

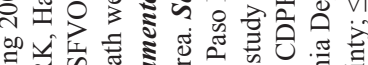

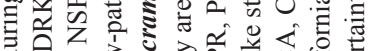

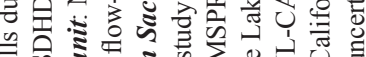

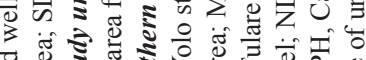

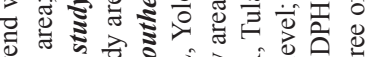

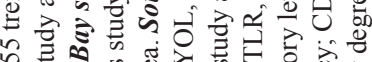

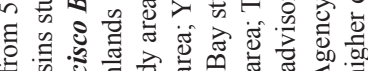

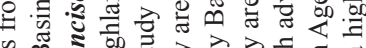

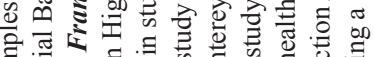

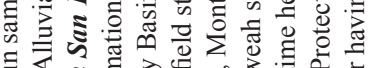
준 总

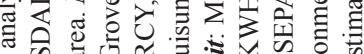

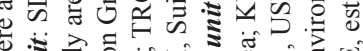

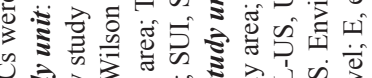

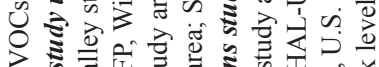

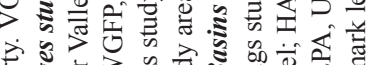

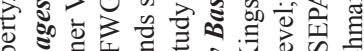

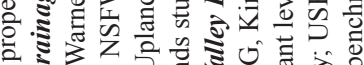
政

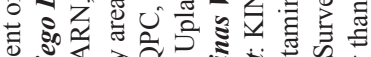

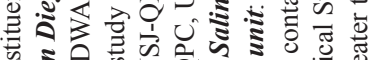

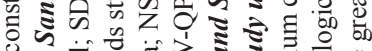

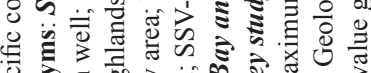

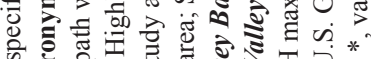
2

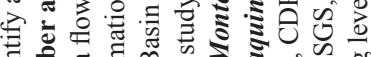

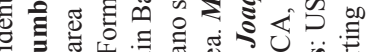

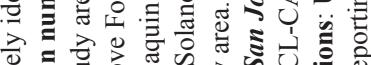

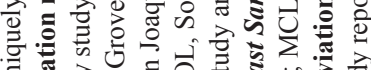
等 o

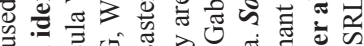

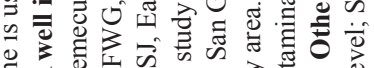

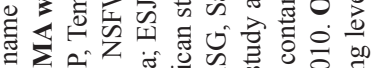

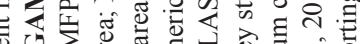

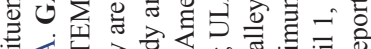

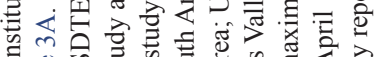
o응

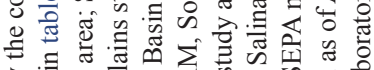

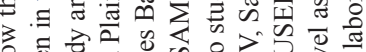

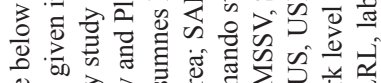

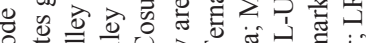
응

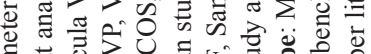

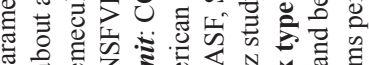

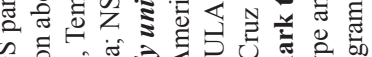

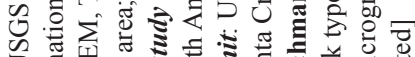

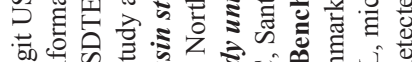

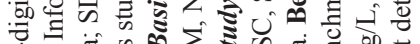

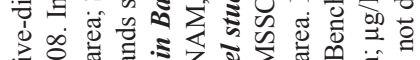

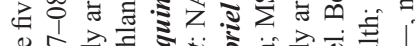

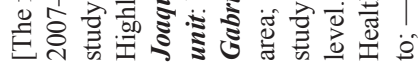
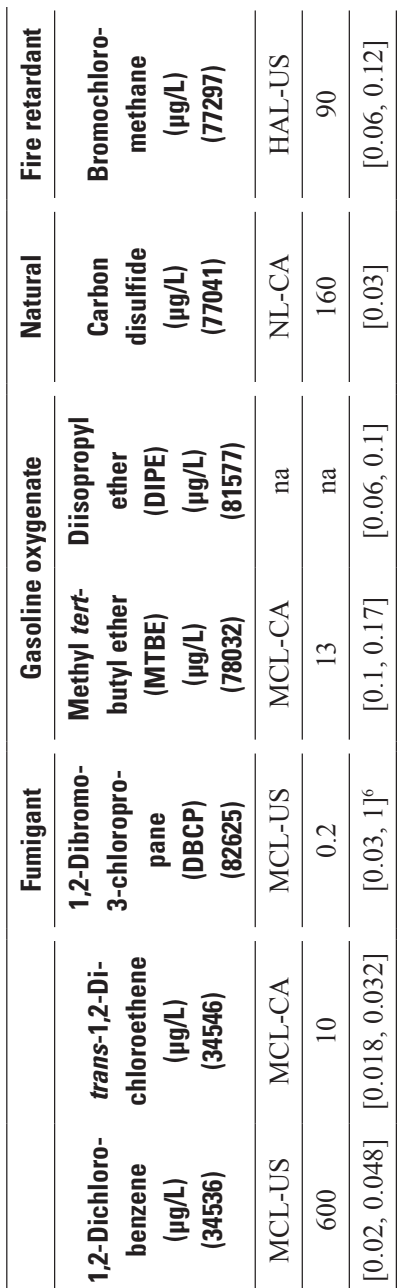

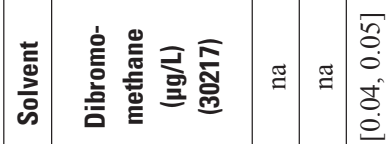

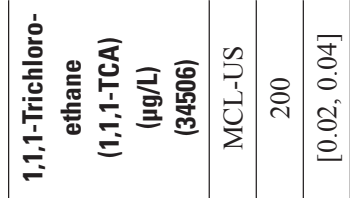

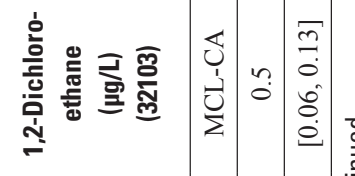

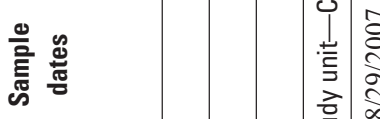

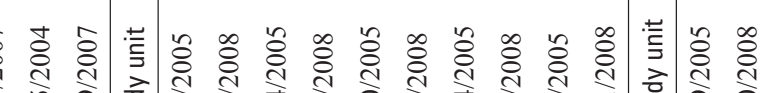

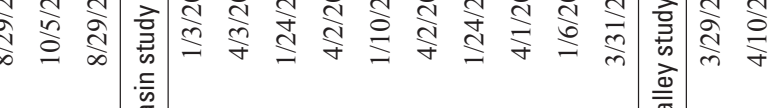

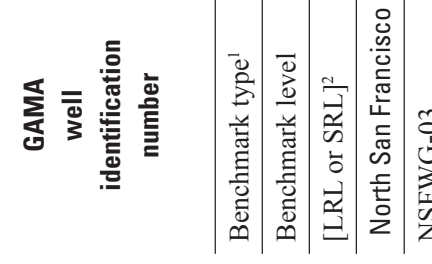
竞章 
Tables $\quad 77$

ช 는

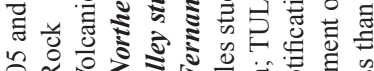

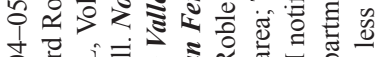

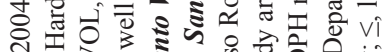

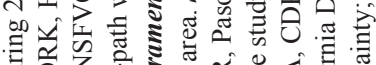
言等

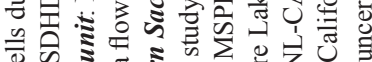

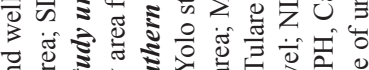

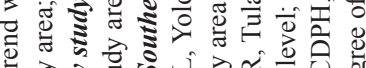

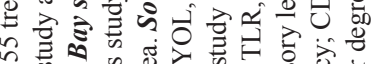

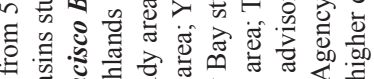

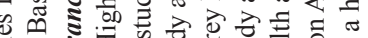

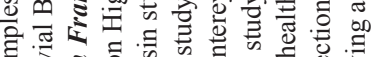

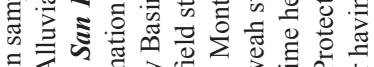

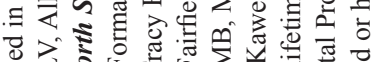

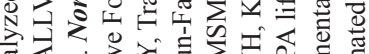

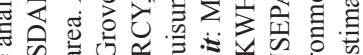

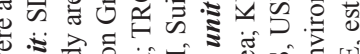

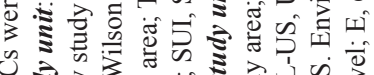
记

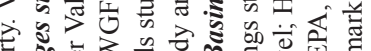

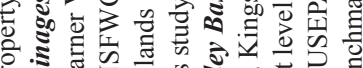

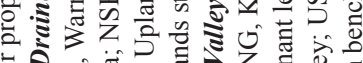

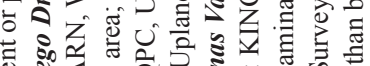

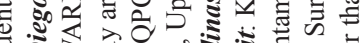

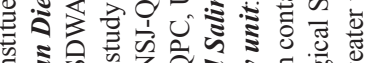

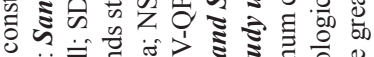

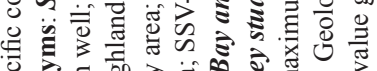

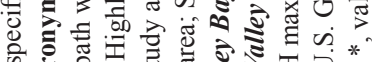
कू

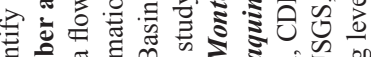

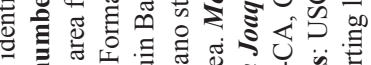

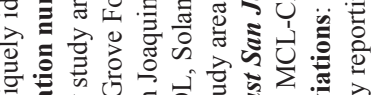
늘

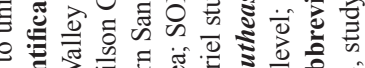

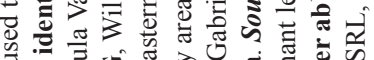

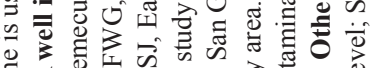

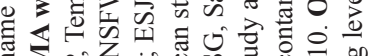

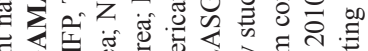

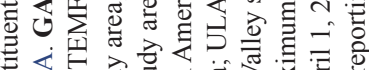

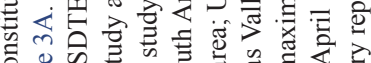

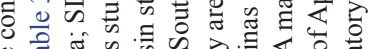

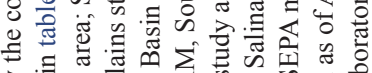

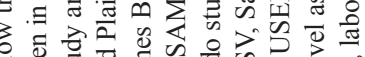

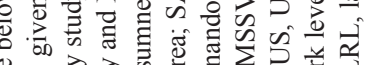

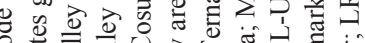

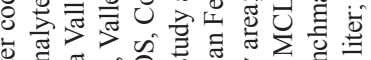

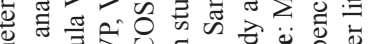

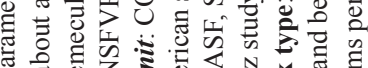

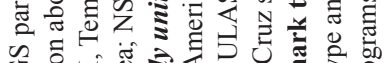

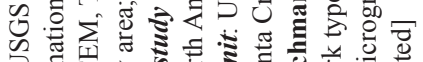

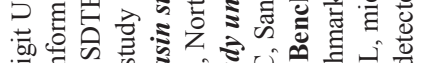
क्ष की

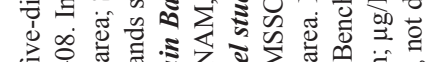

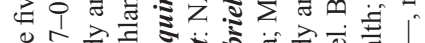

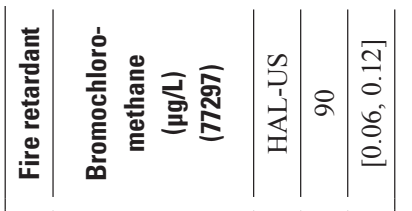

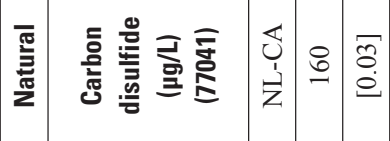

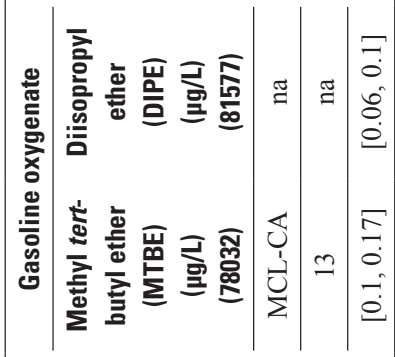

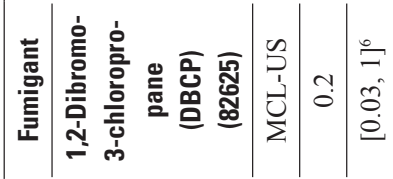

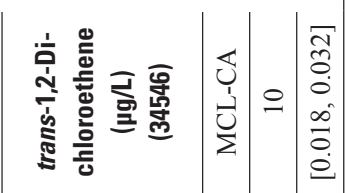

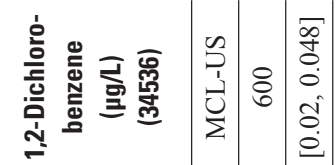

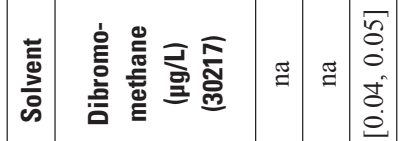

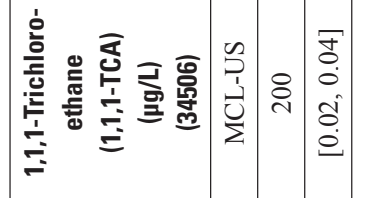

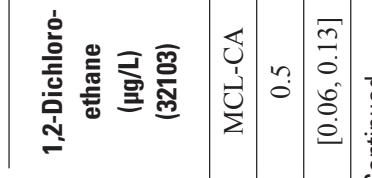

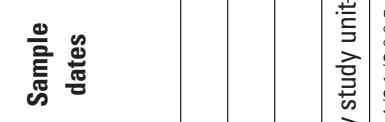

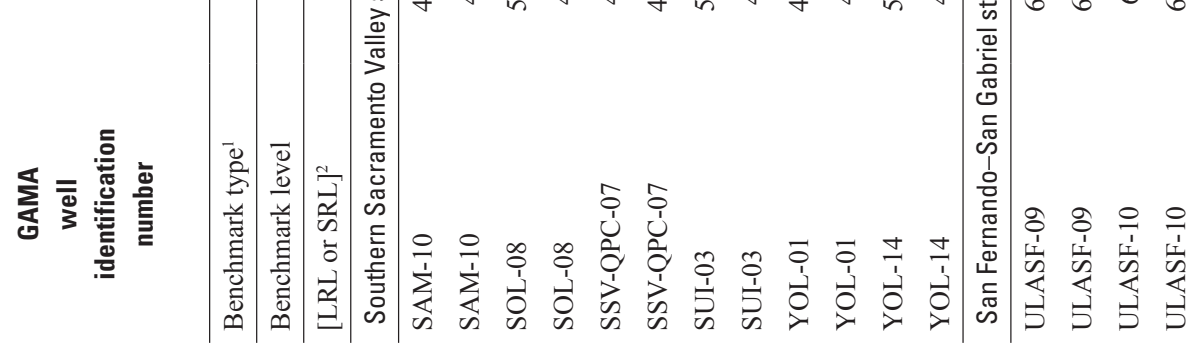



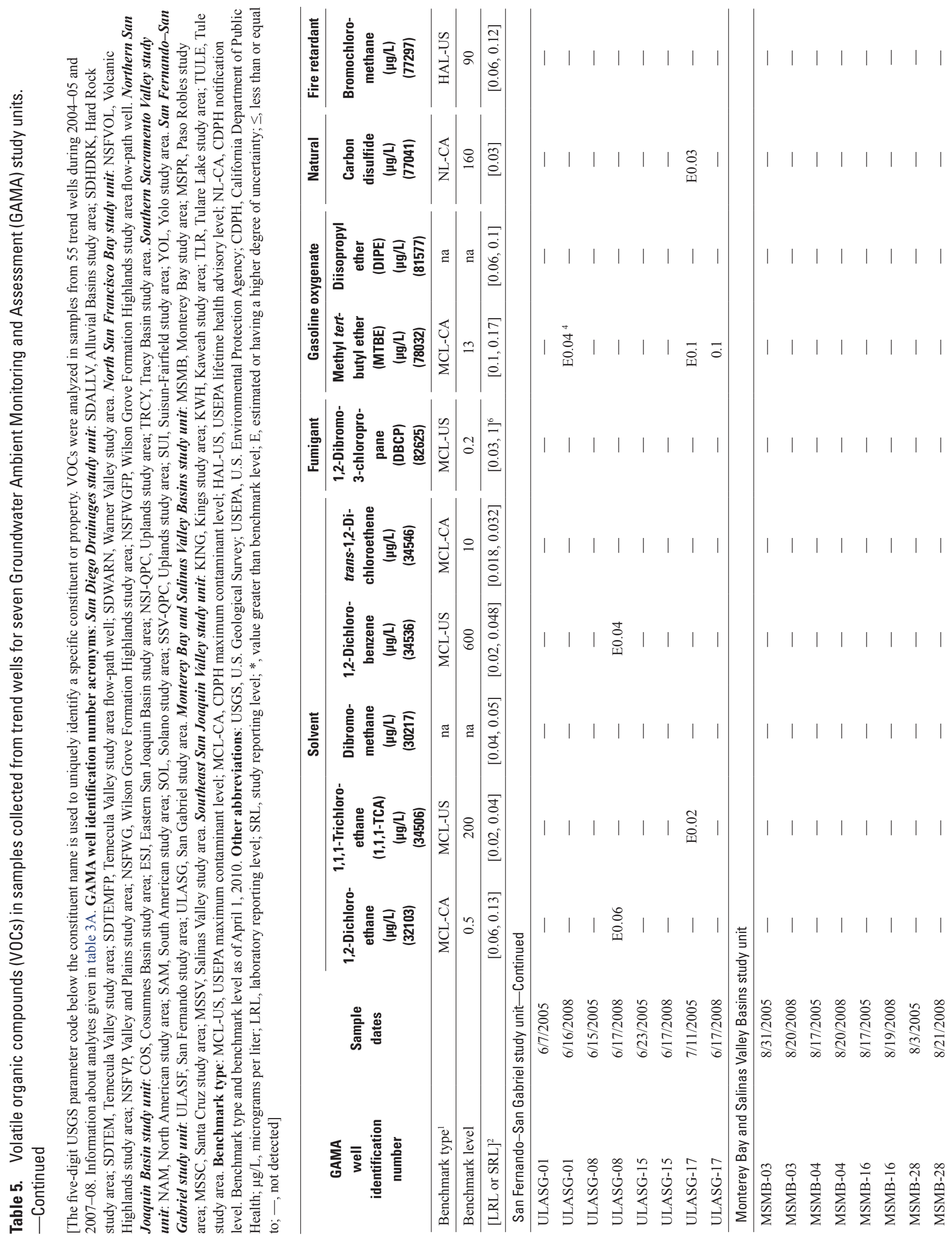
चำ 는 此

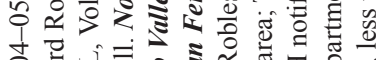

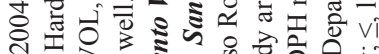

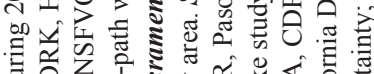

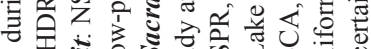

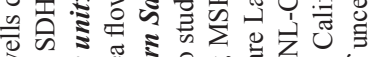

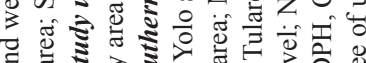

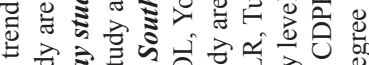

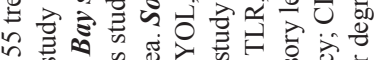

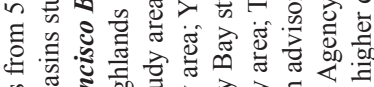

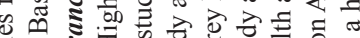

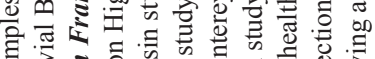

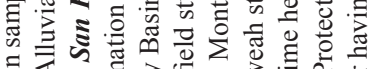

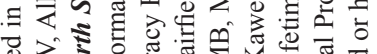

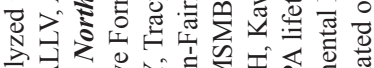

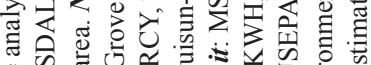

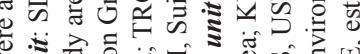

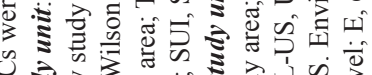
రิ

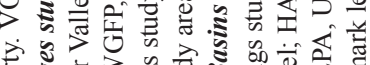

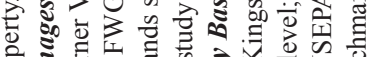

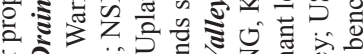
क人

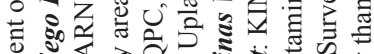

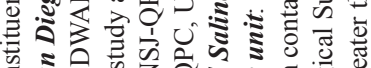

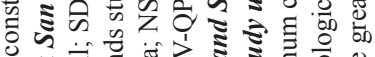

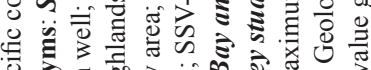

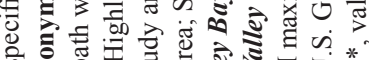
कूष

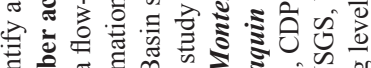

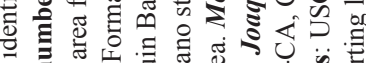
等

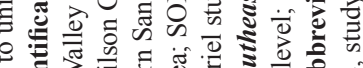

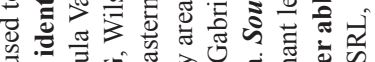

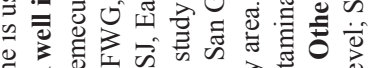

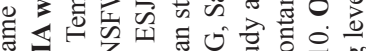

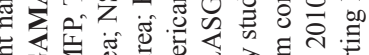

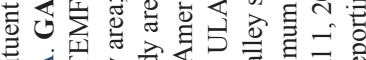

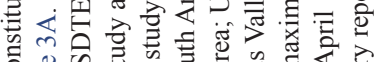
o의 की

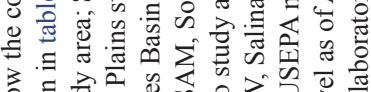

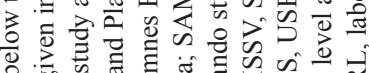

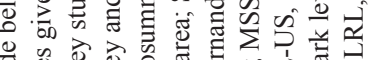

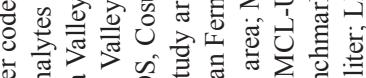

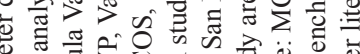

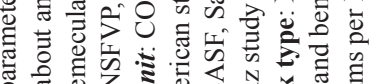

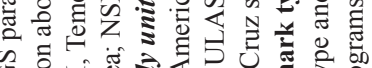

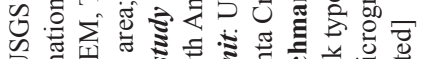

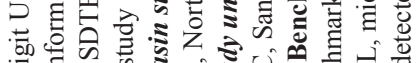
-50 की

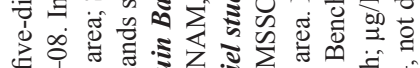

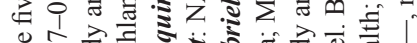

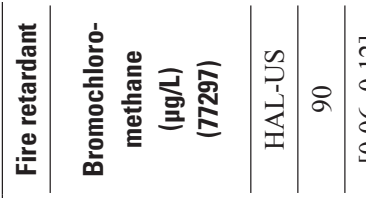

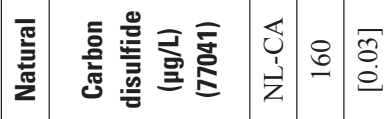

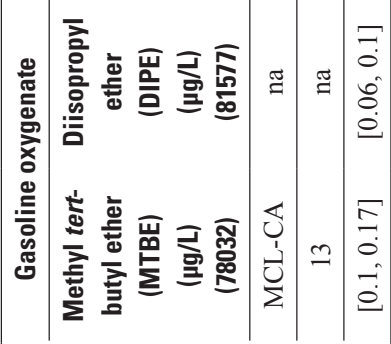

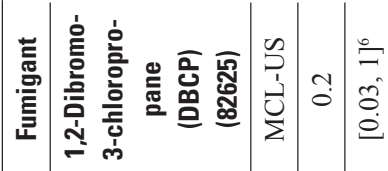

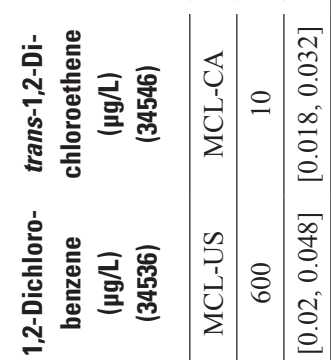

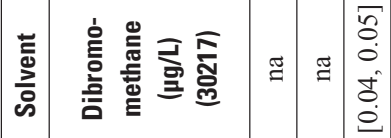

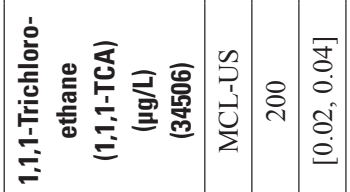

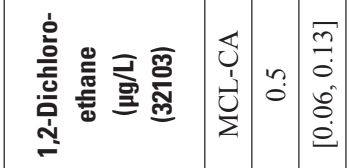

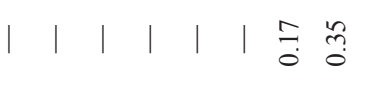




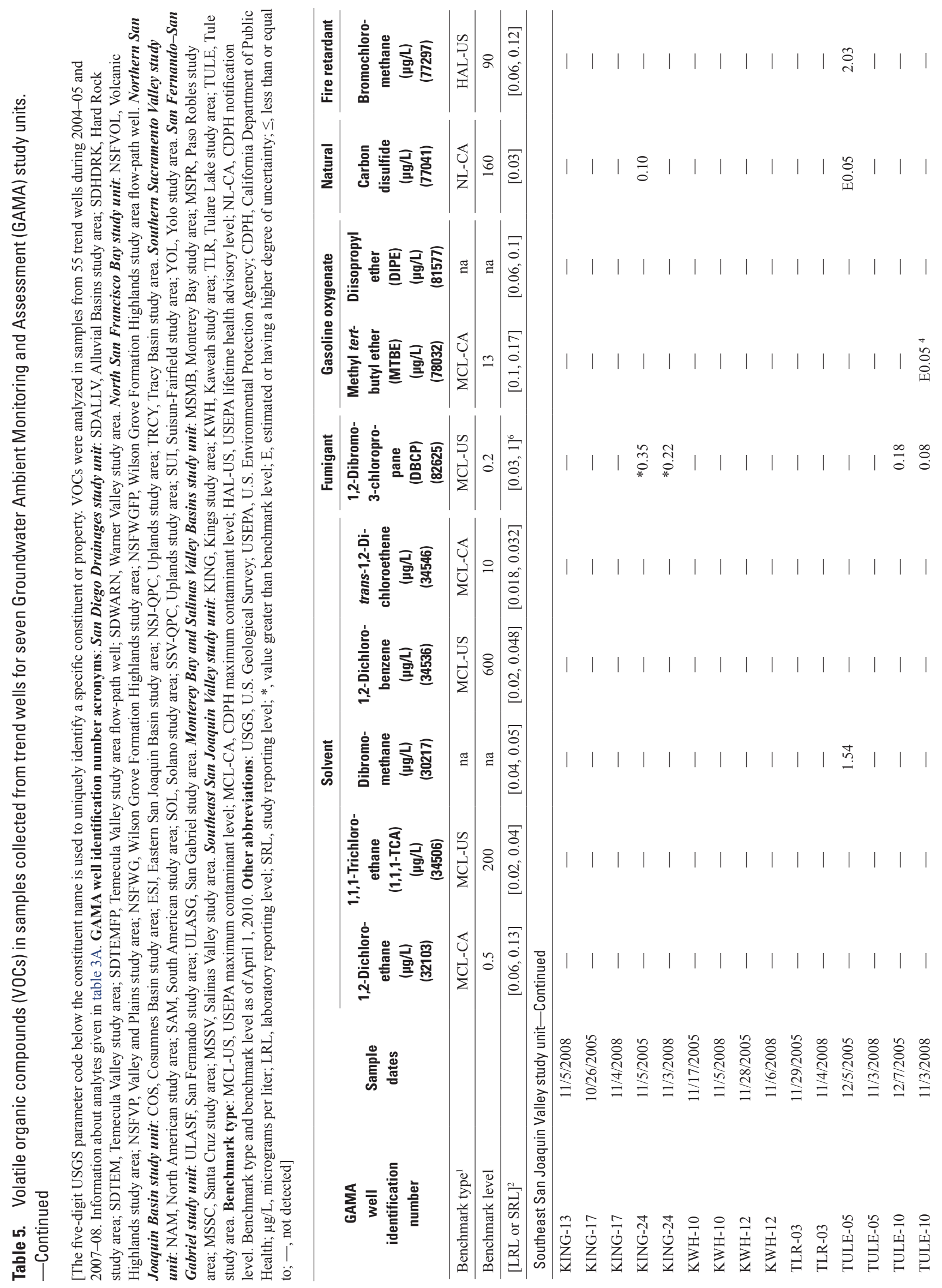




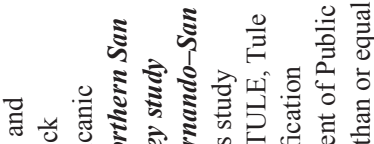

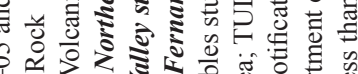

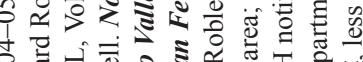

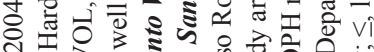
on $)$

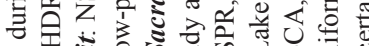

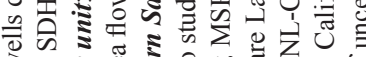
记 क्ष

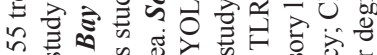
F.

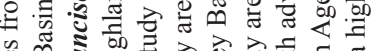

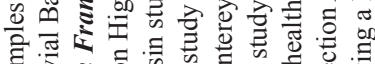

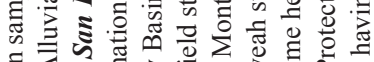

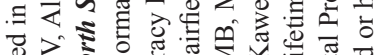
굴

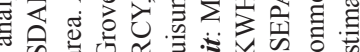
क

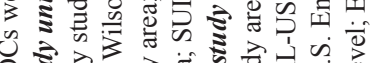

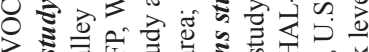
局

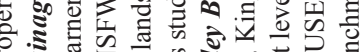

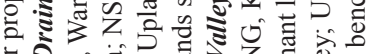

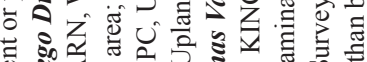

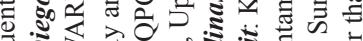

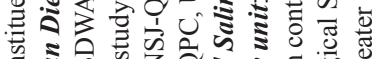
के की

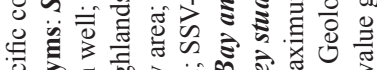

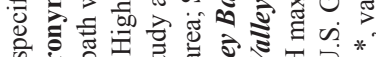
की

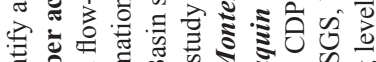

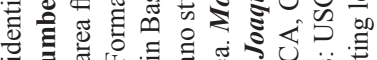

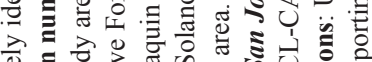

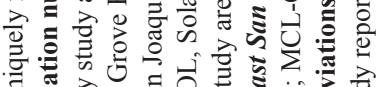

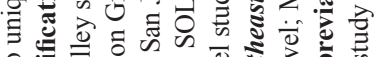

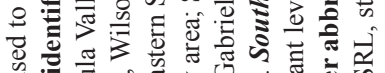

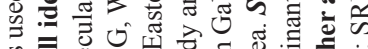

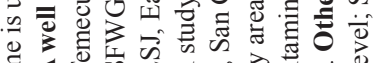

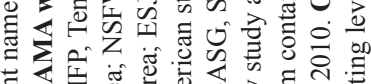

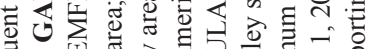

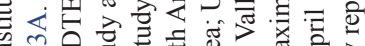

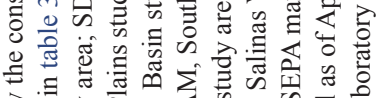

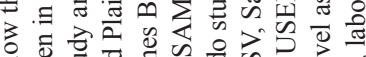

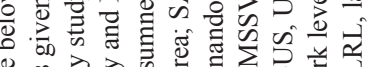

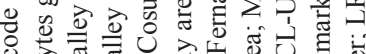

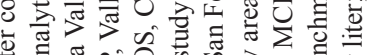

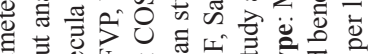

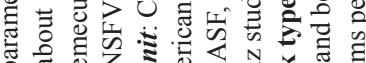

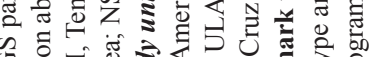

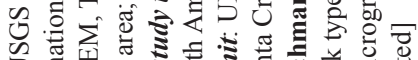

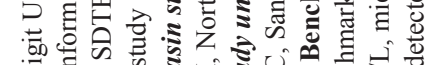

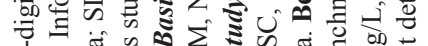

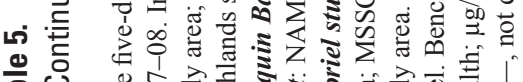
은

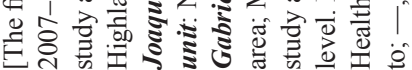

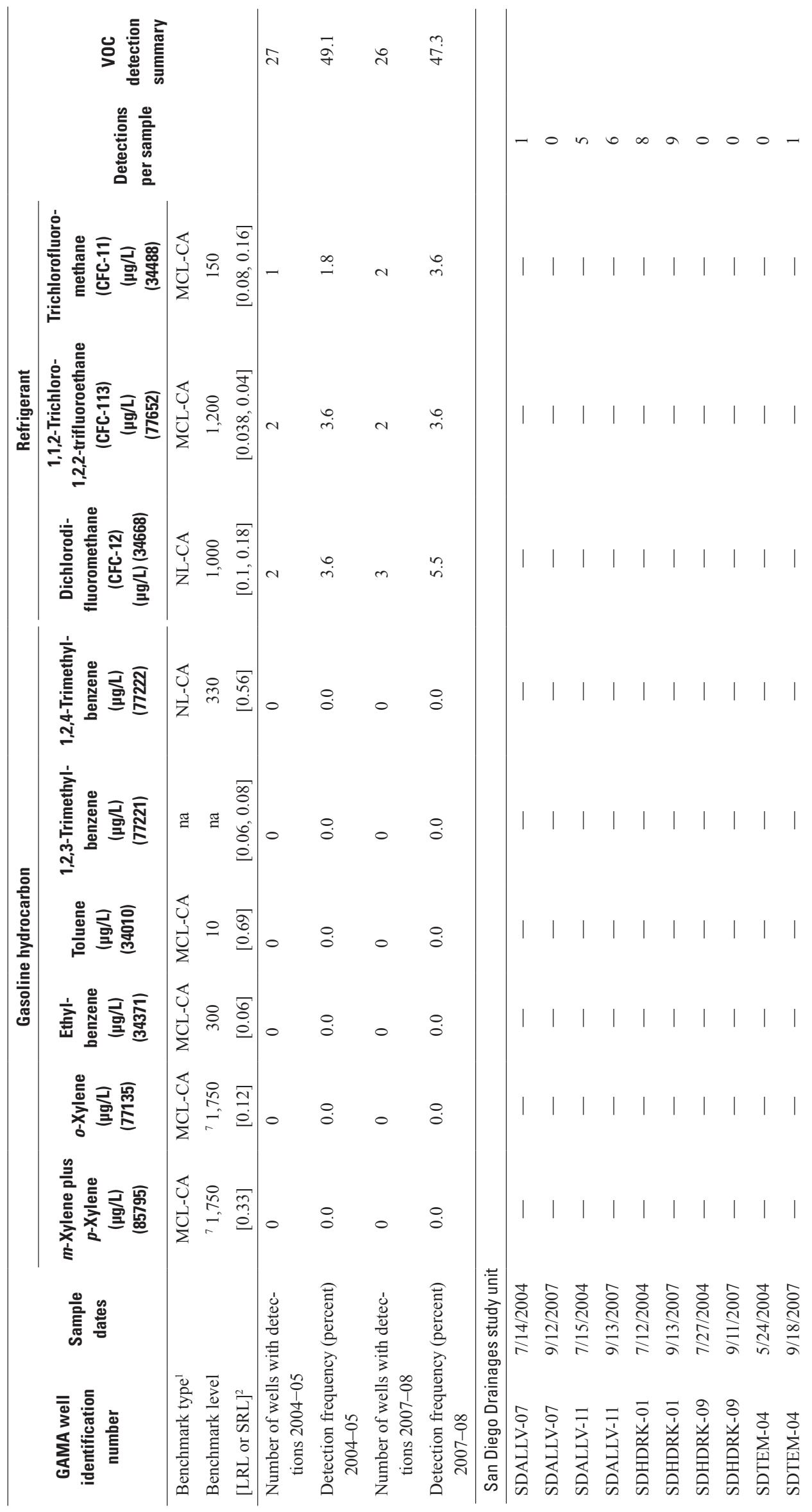



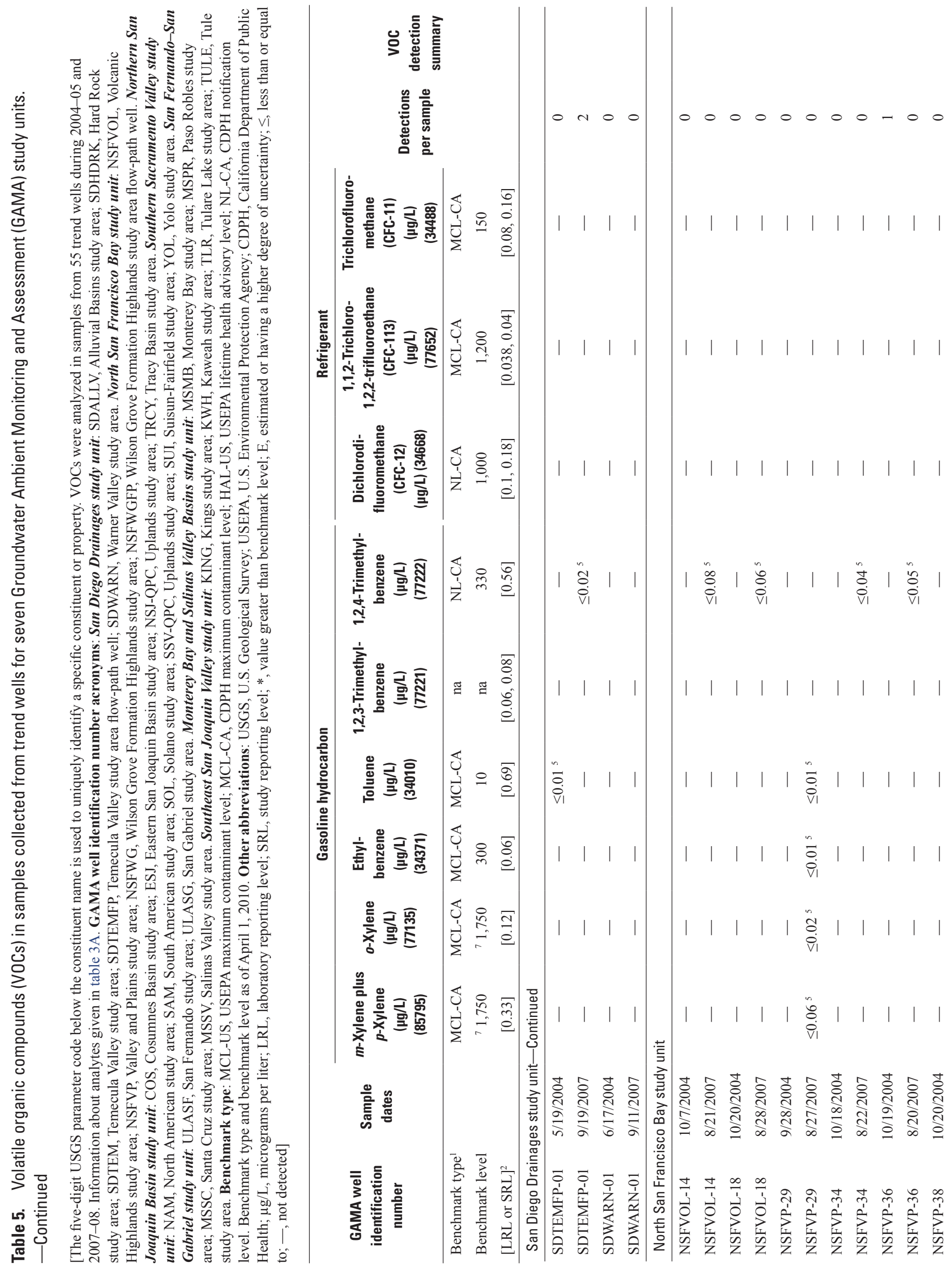


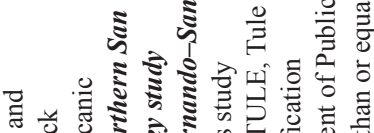

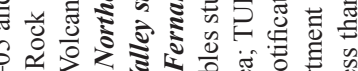
4 等

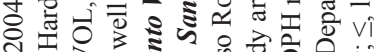
on 3 言会落

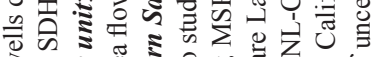

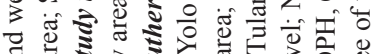

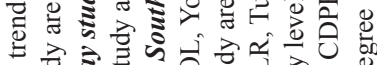

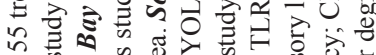
त क \& 의 은

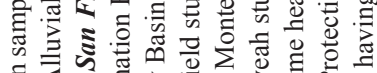

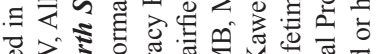

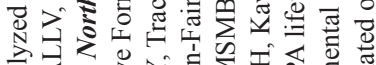

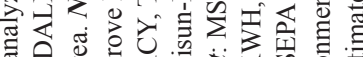

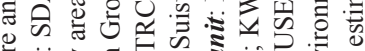

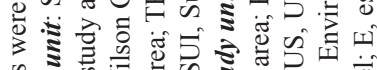
0

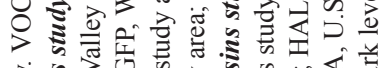

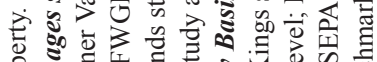

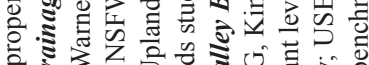

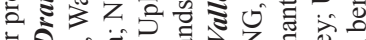

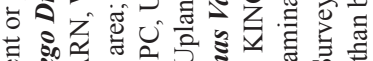

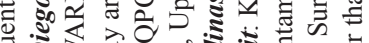

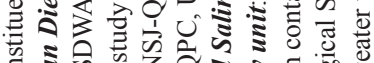
言言 की

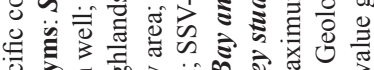

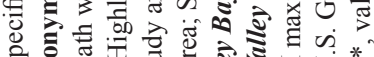
की

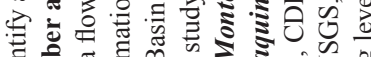

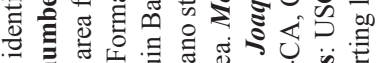

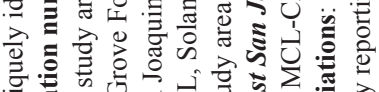

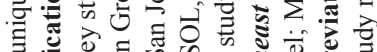

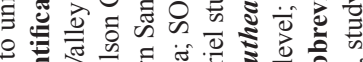

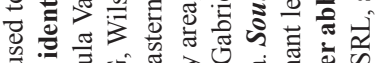

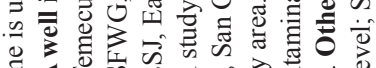

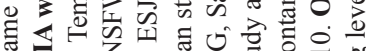
等

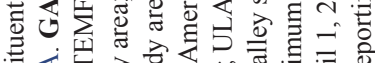

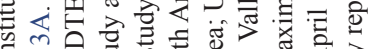

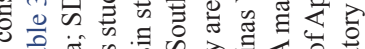

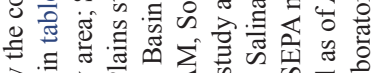
3.

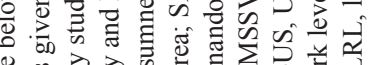

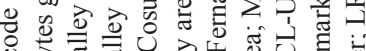

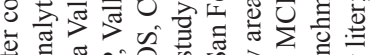

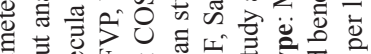

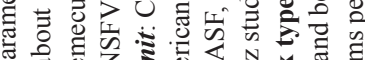

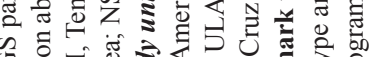

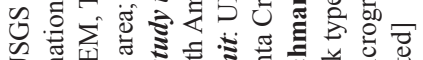

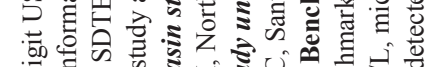

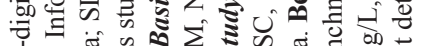

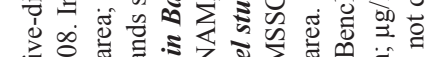

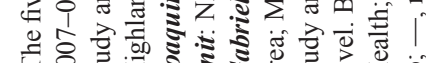

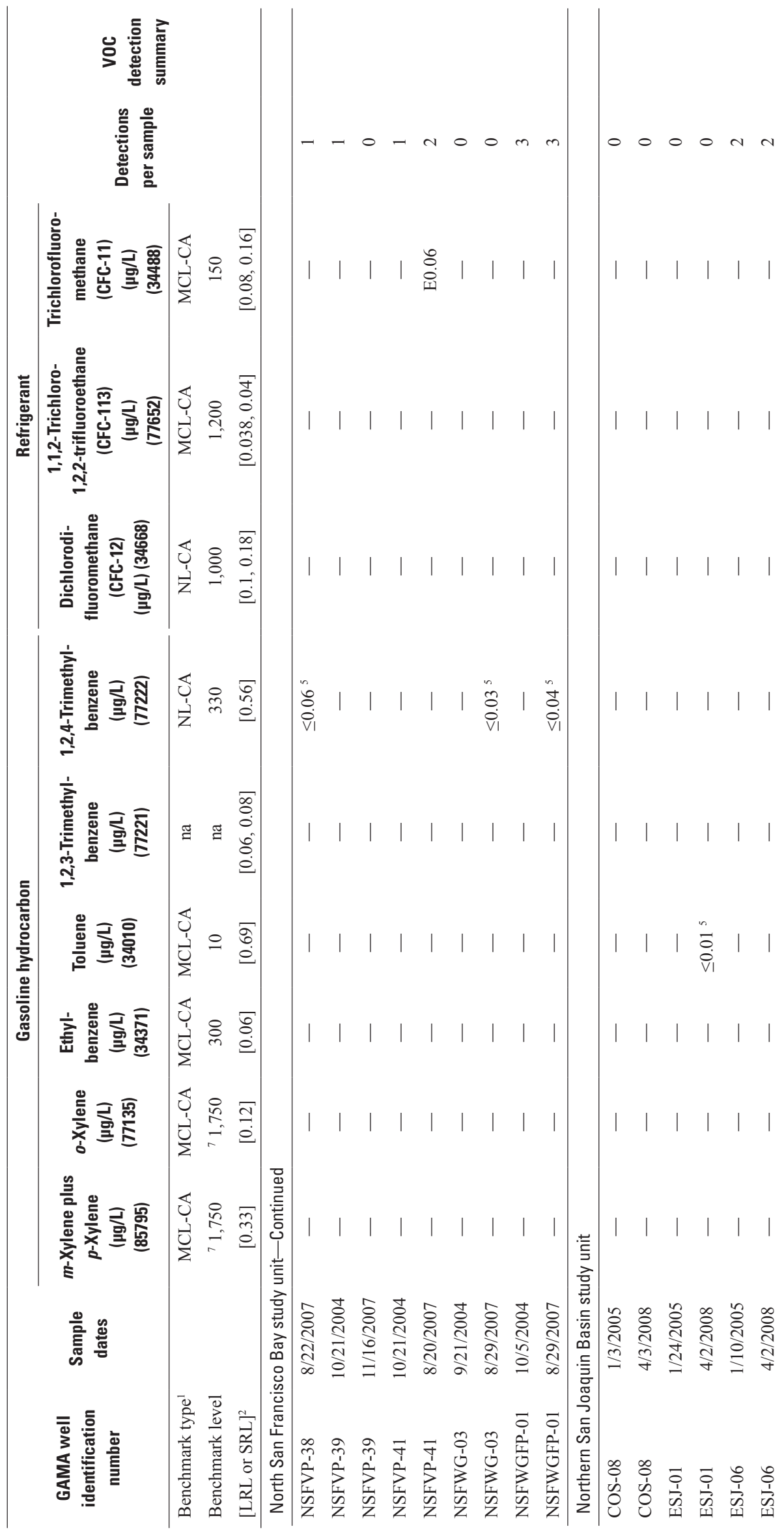



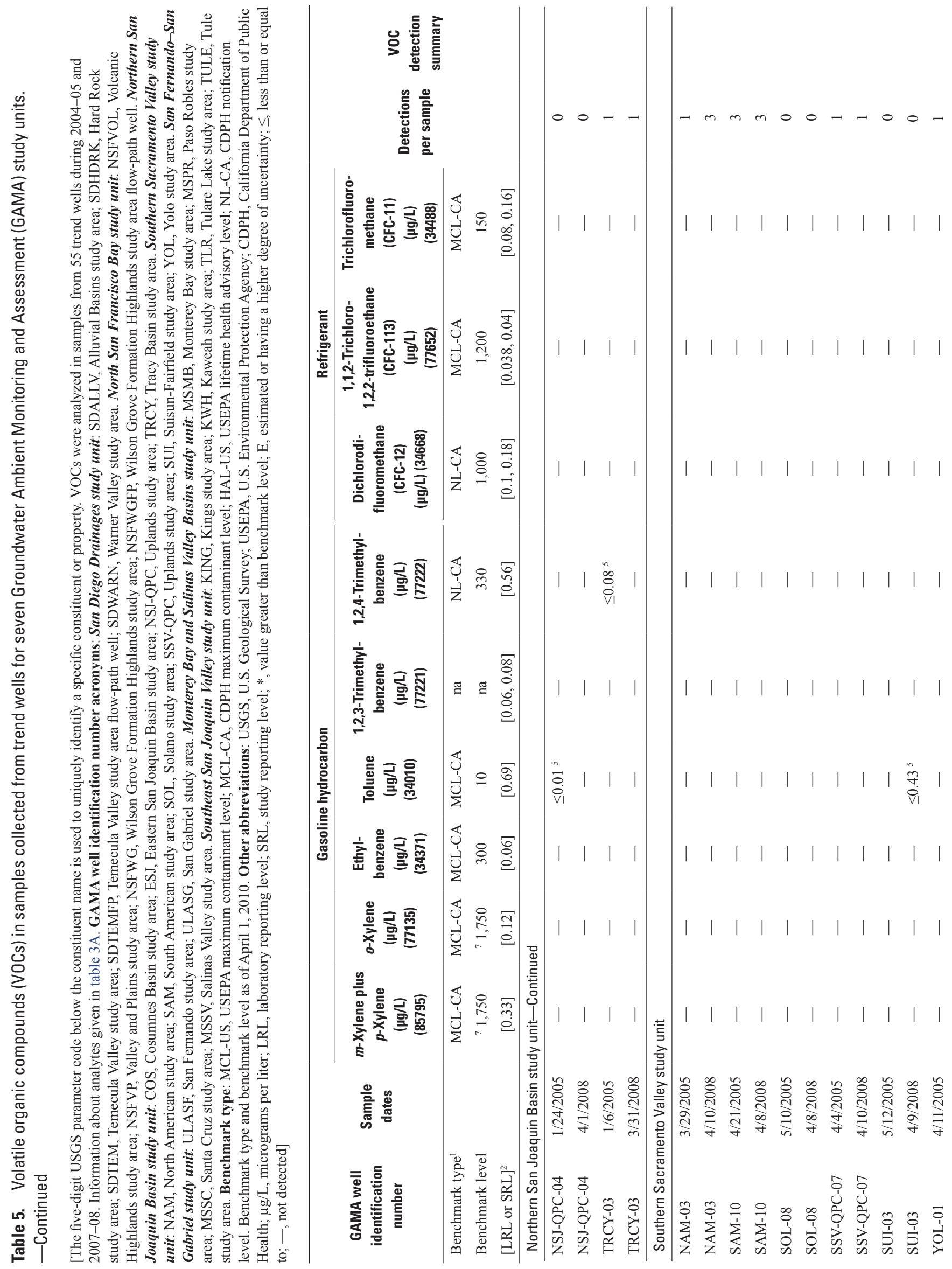


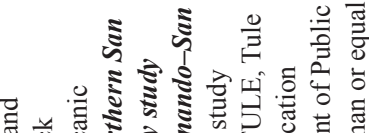

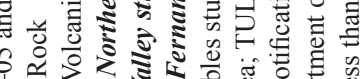

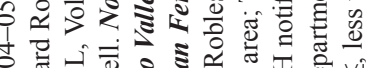
을

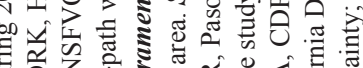

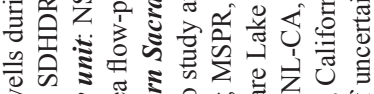

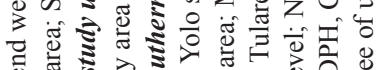

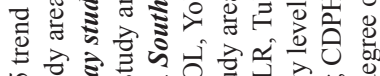

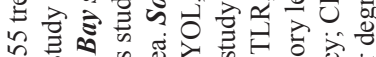

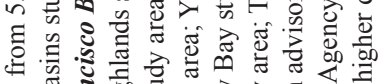

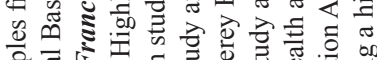

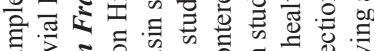

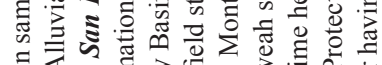

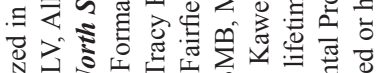

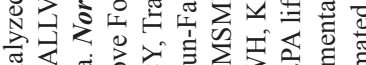

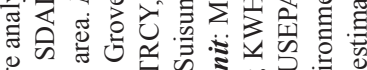
o 等 잉

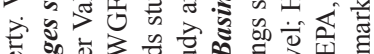

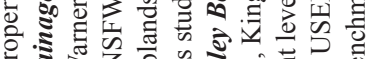
อง

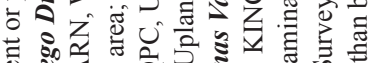
con

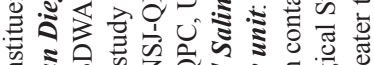

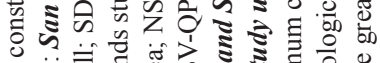

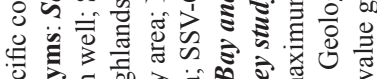

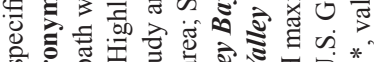
\%

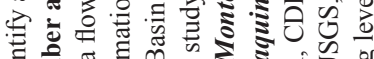

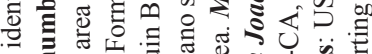

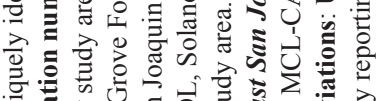

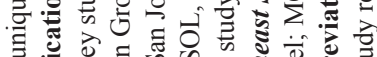

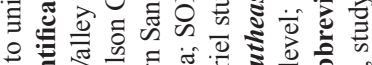

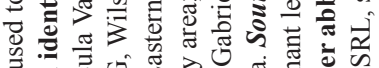

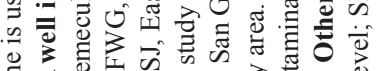

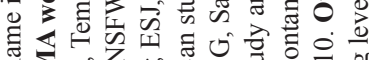

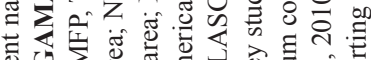

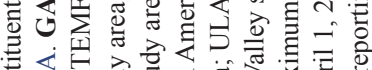

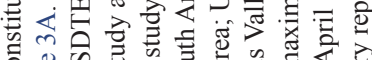

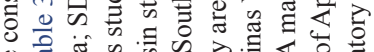

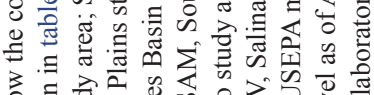

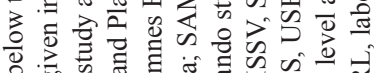

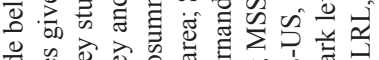
5 g

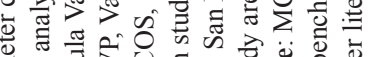

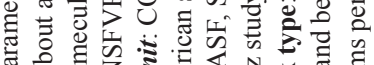

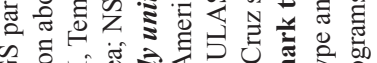

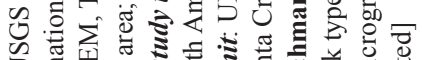

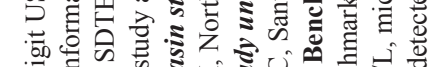

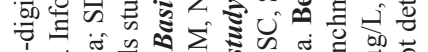

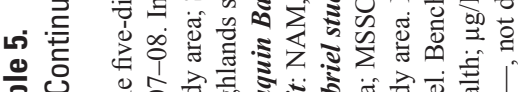

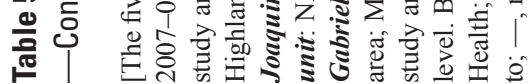

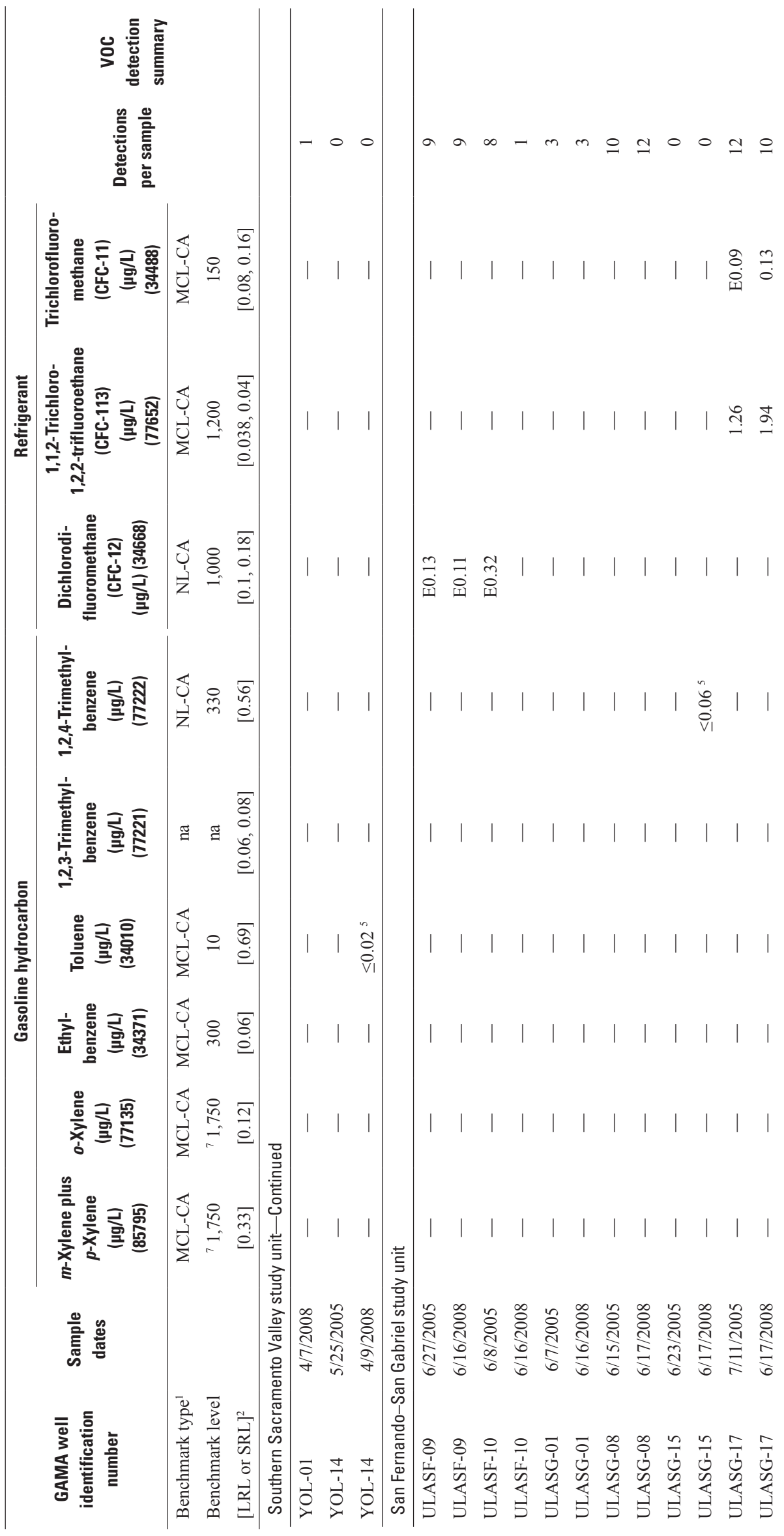



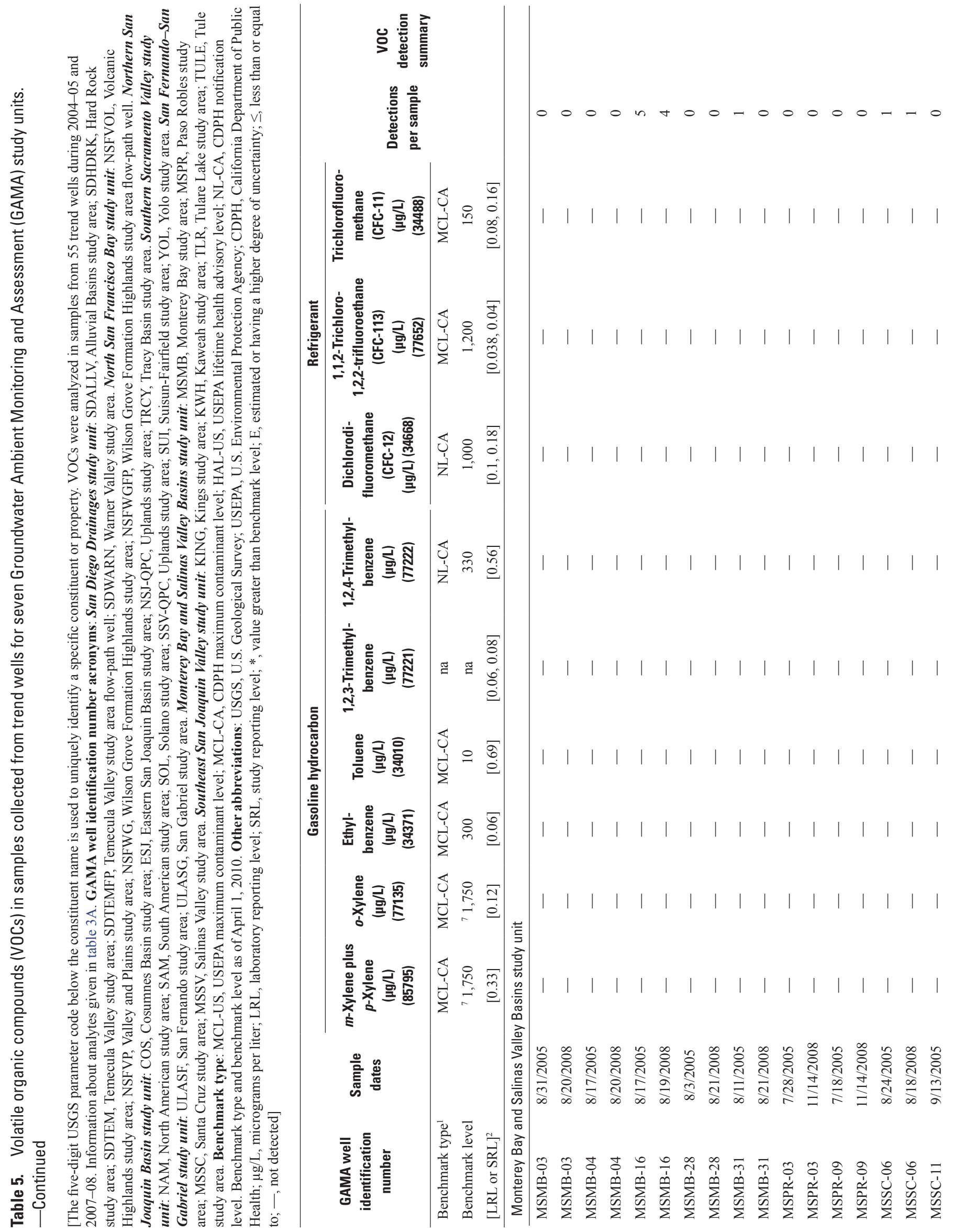

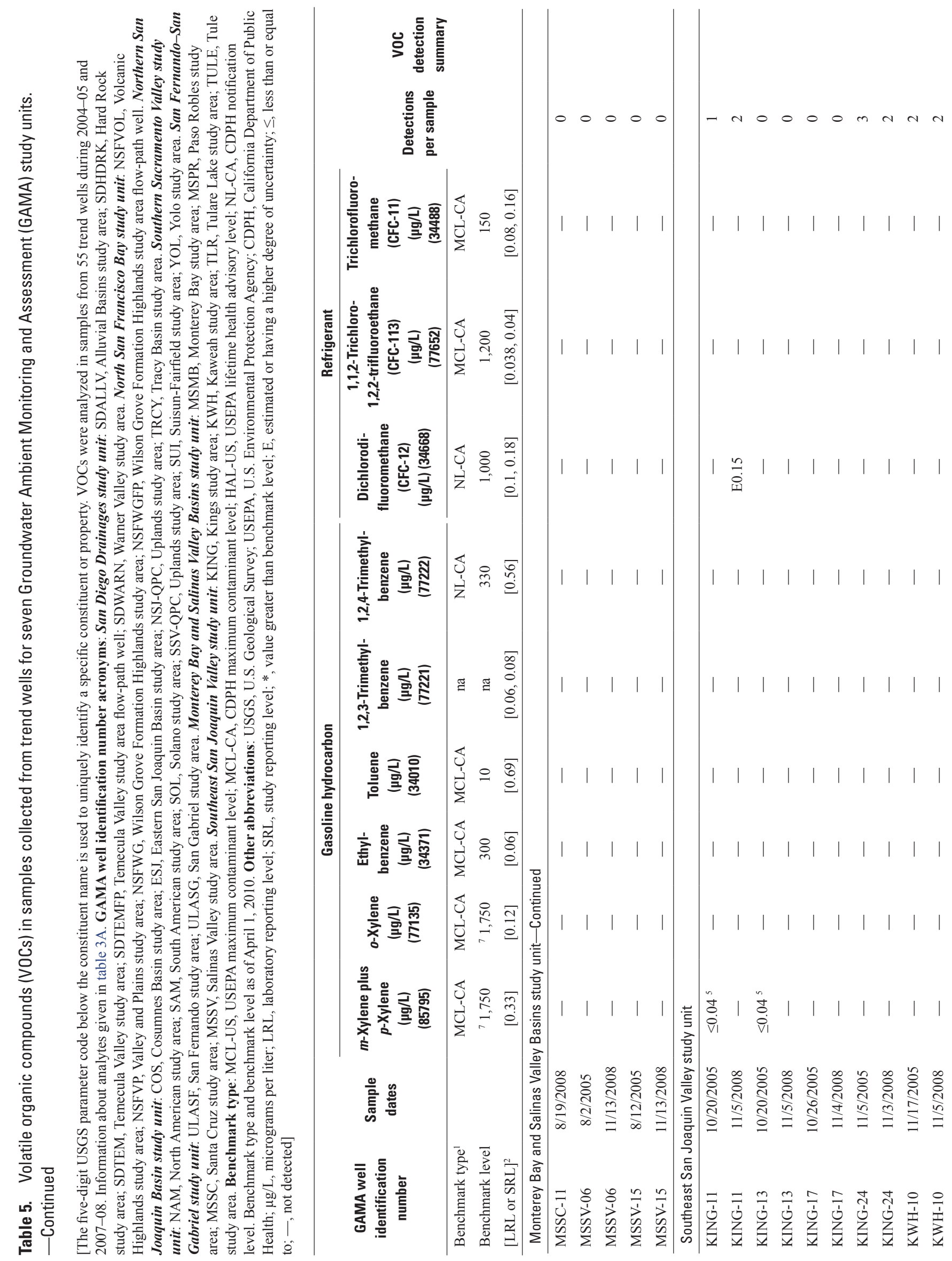


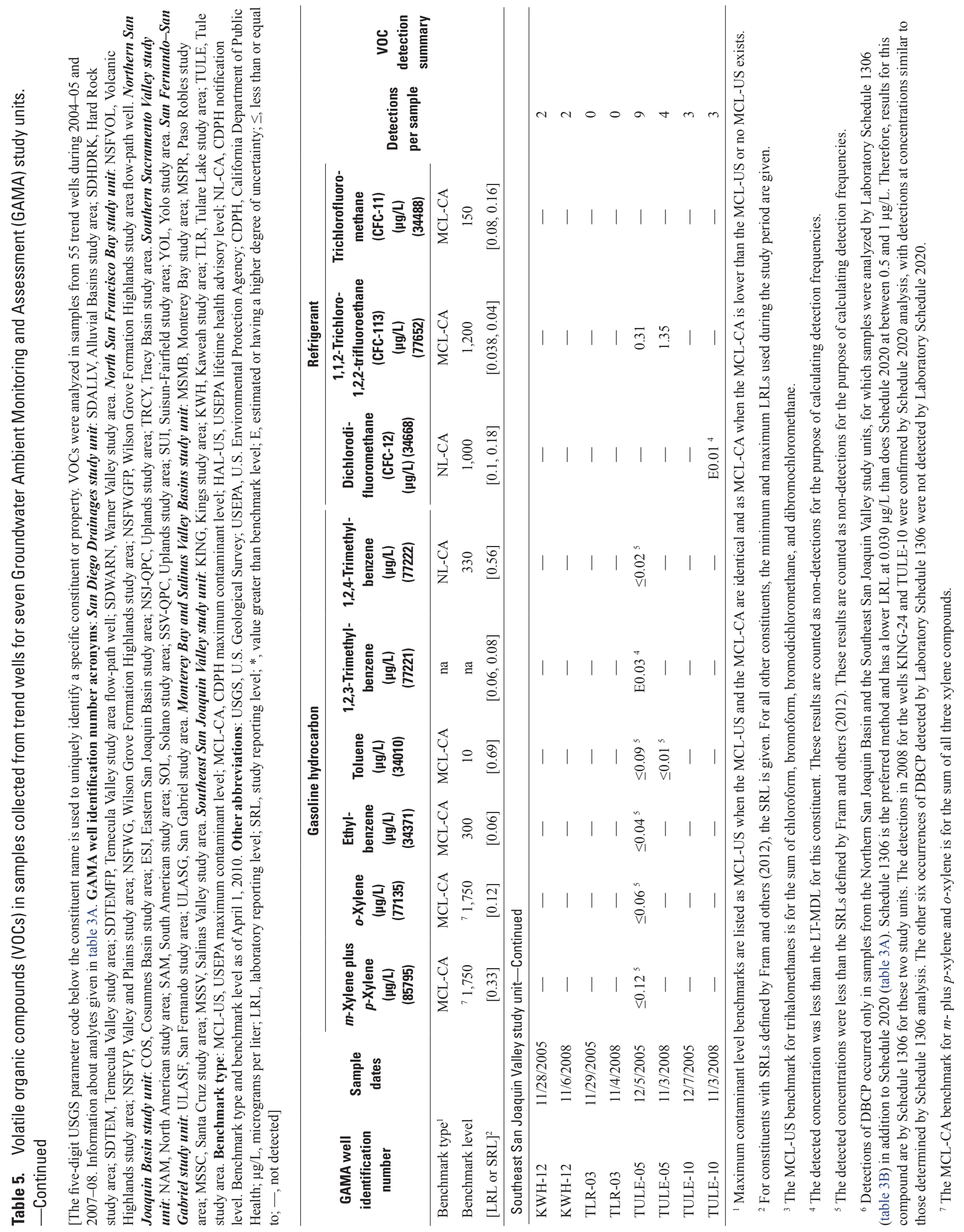




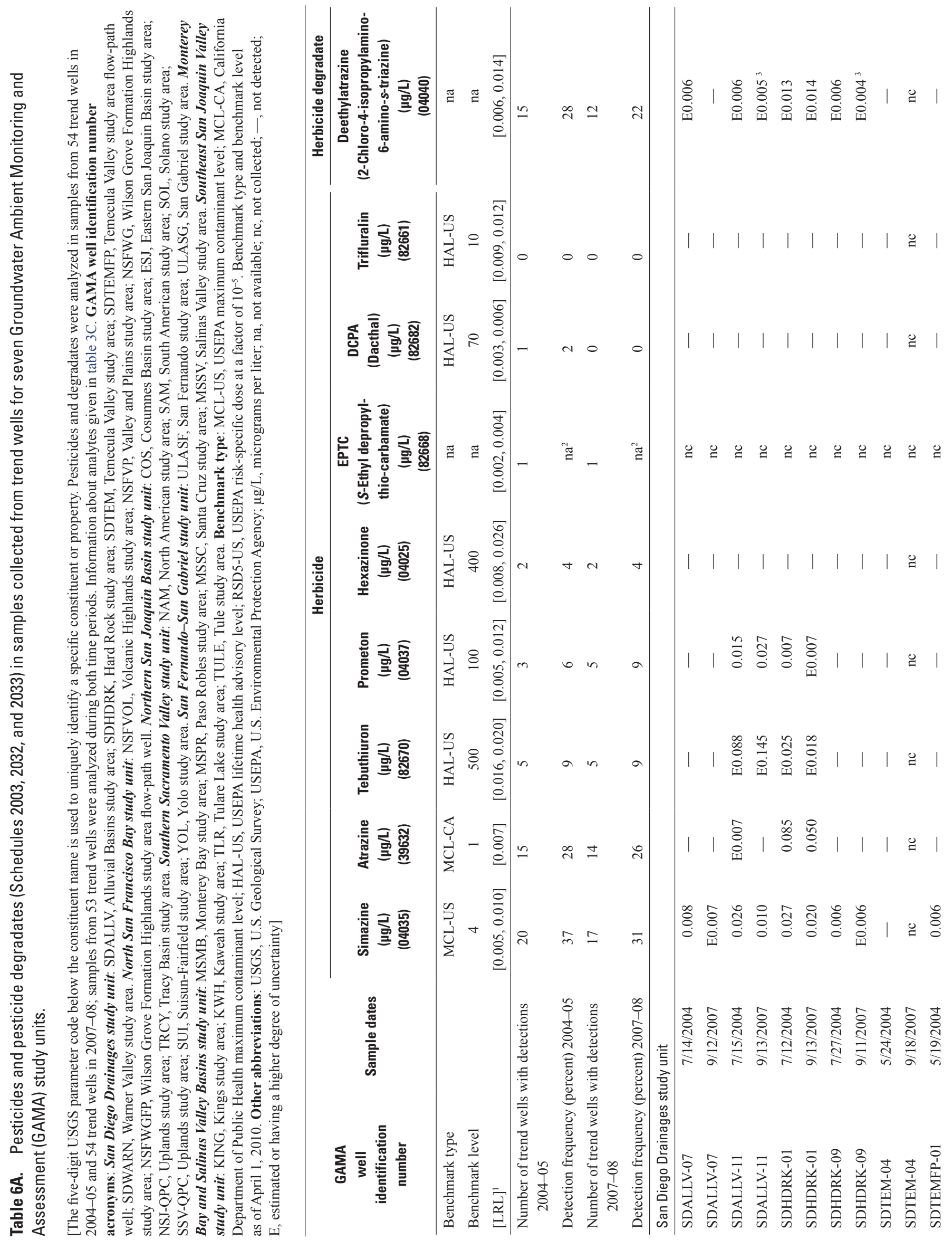


I

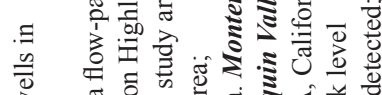

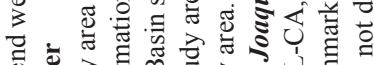

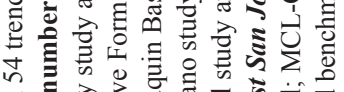

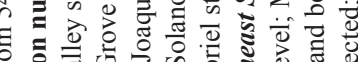

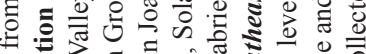
पै

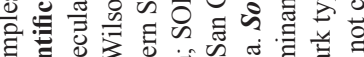

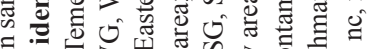

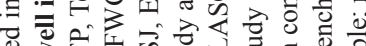

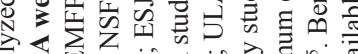

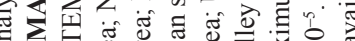

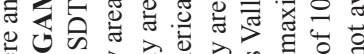

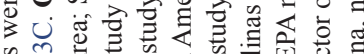

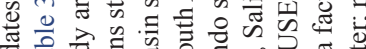

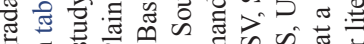

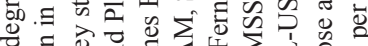

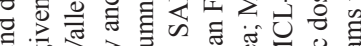

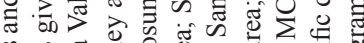

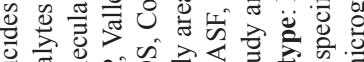

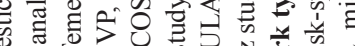

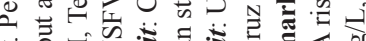

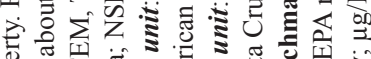

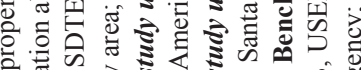
o

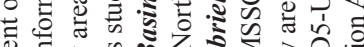

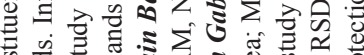

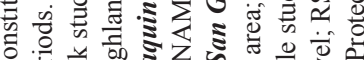

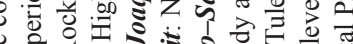

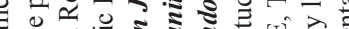

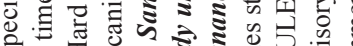

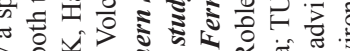

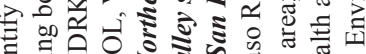

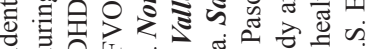

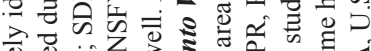

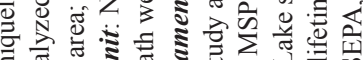

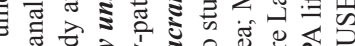

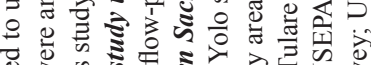

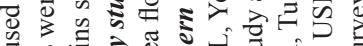

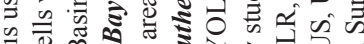
\%

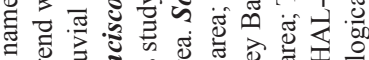
可引

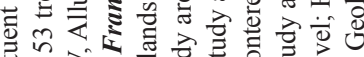

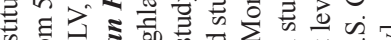

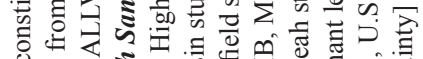

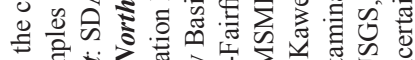

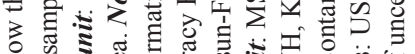

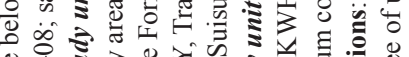

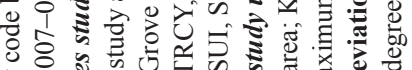

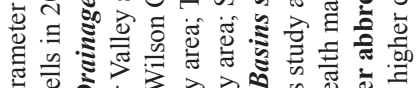

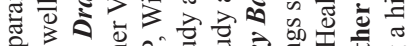

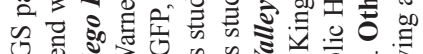

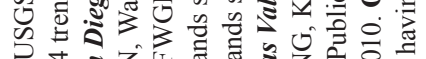

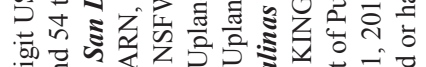

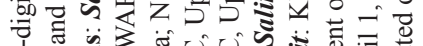
১े

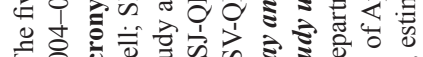

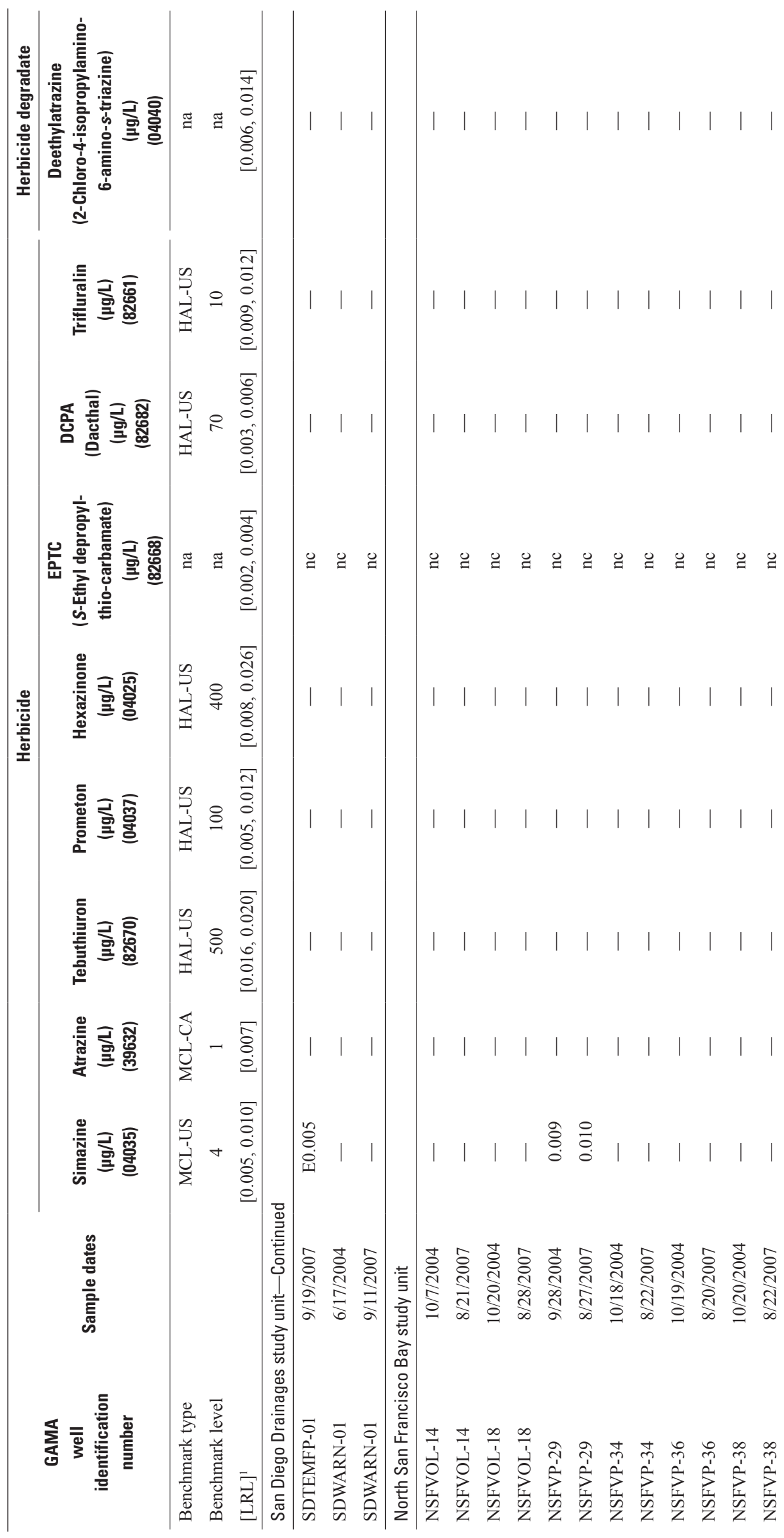




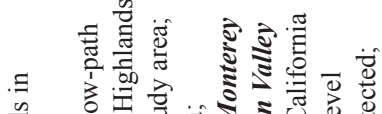

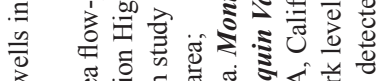

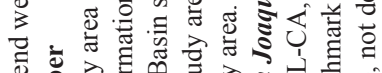

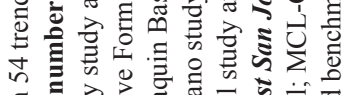

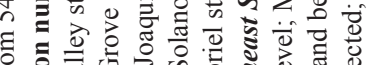

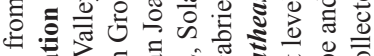
क छี

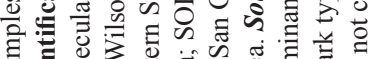

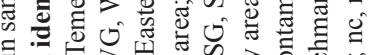

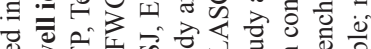

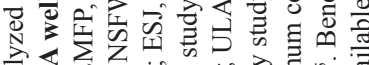

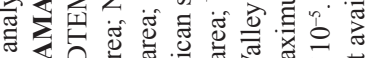

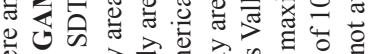

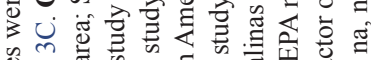

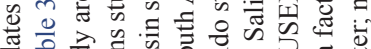

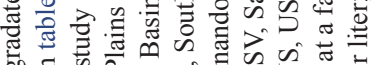
कo $\equiv$ कि

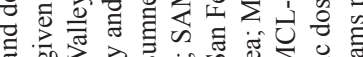
का

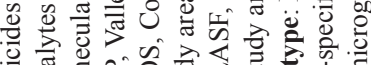

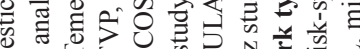
政

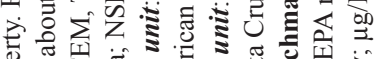

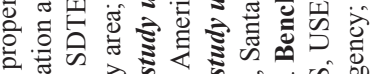

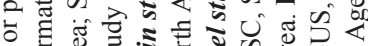

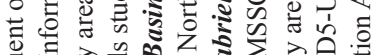

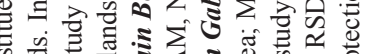

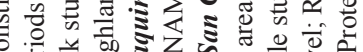
००

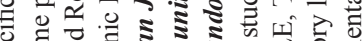

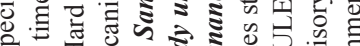

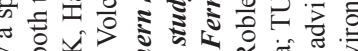

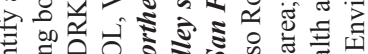

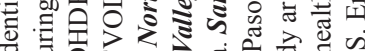

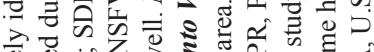

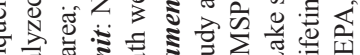

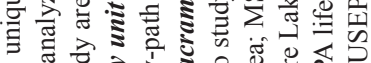

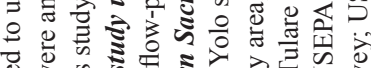

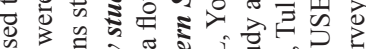

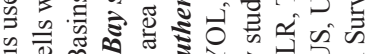
ब๊

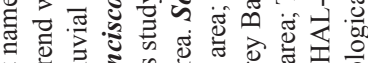

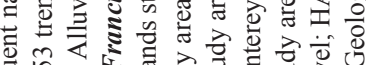

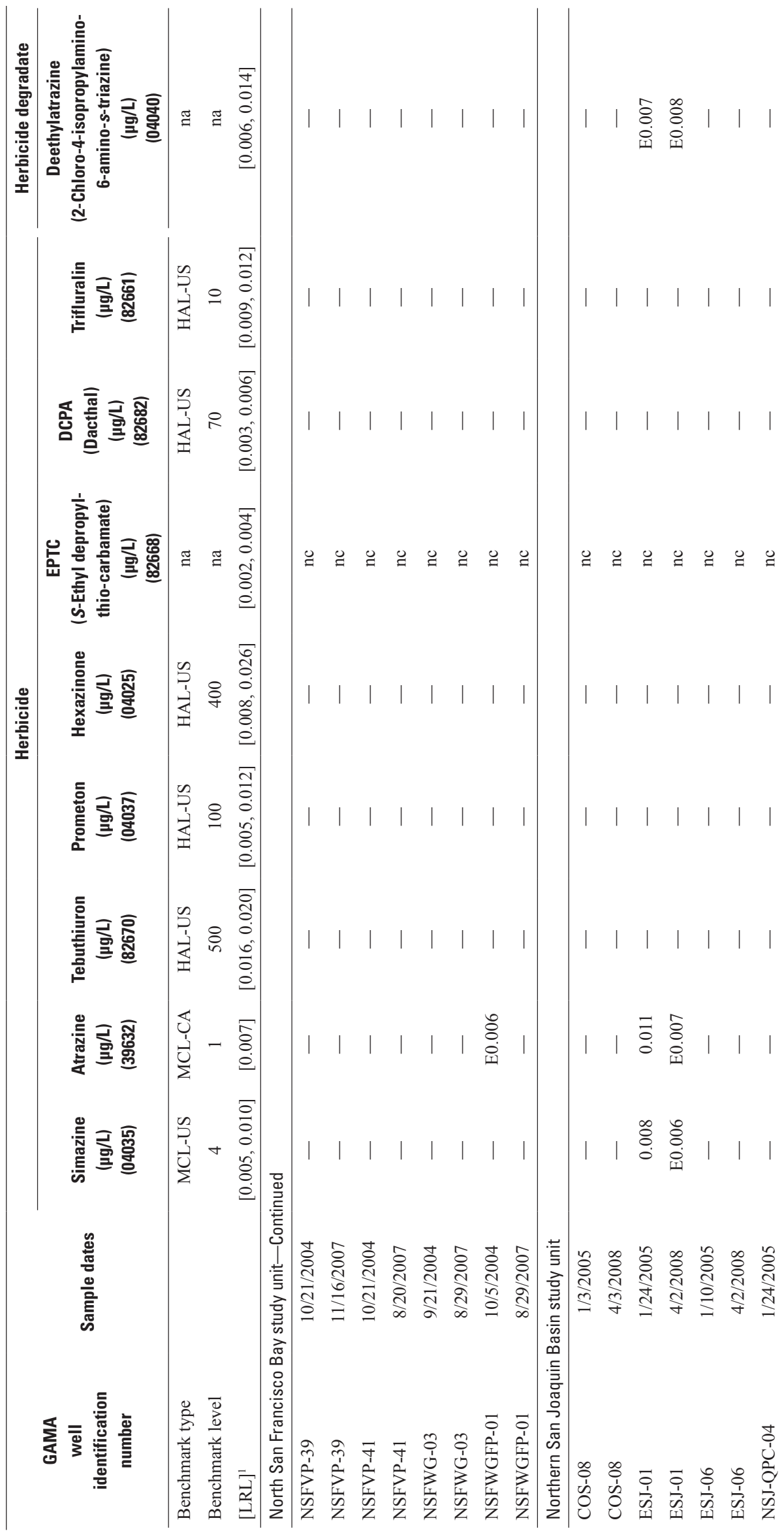




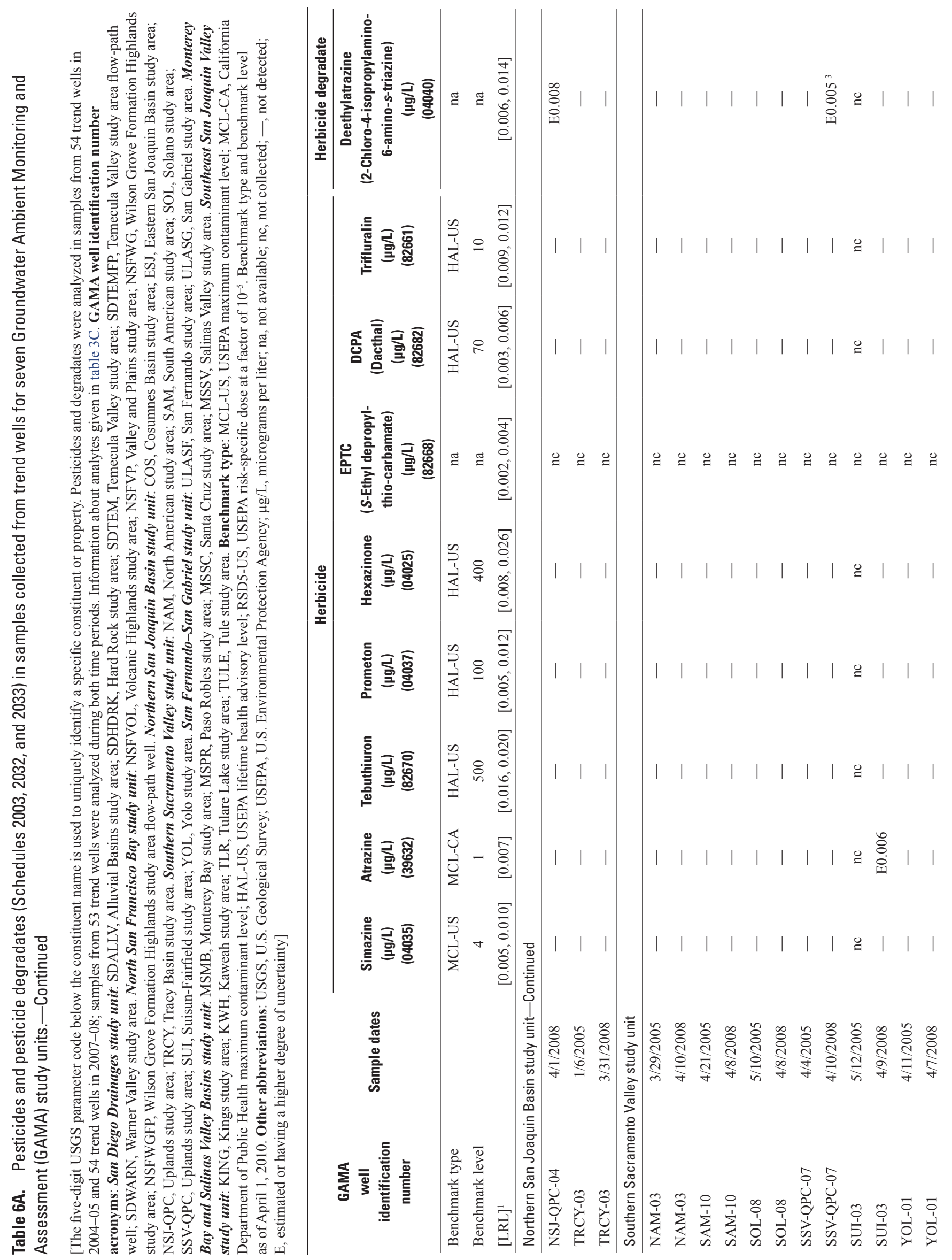


.

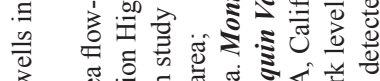

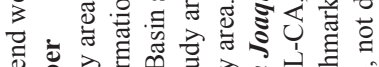

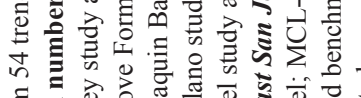

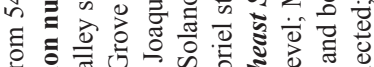

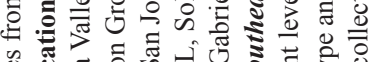

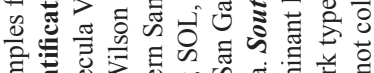

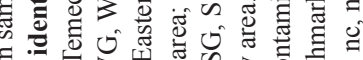

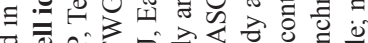

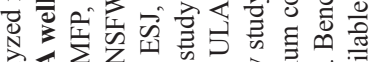

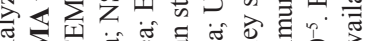

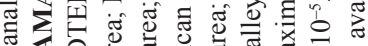

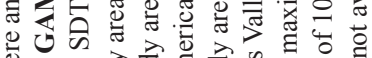

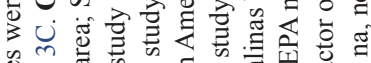

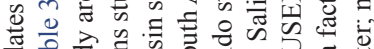

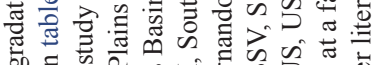

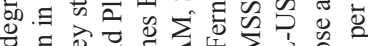

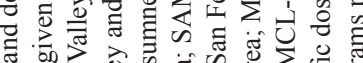

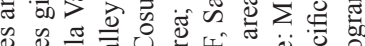

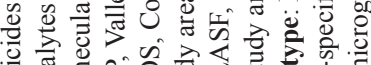

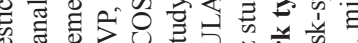

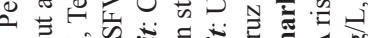

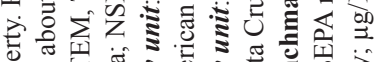

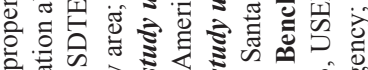

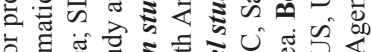
च टँ

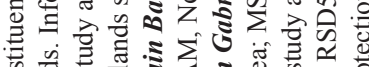

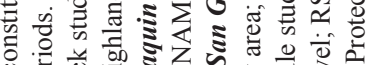

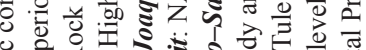

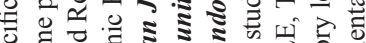

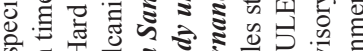

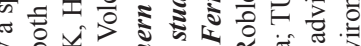
屯ํ.

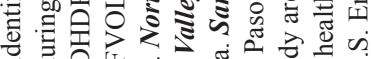

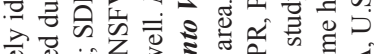

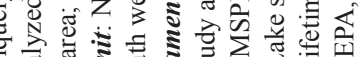

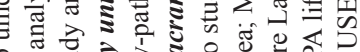
至至

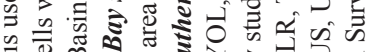

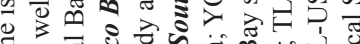

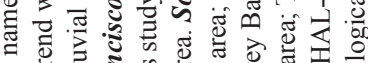

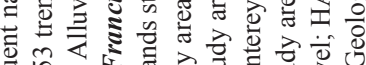

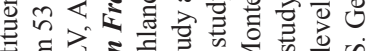

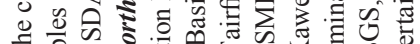

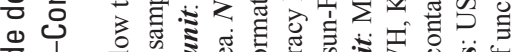

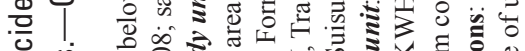

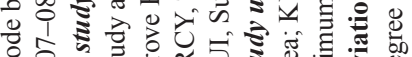
¿

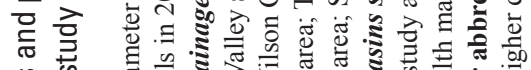

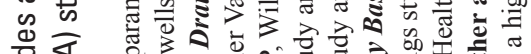

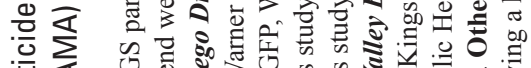
.

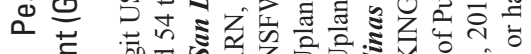

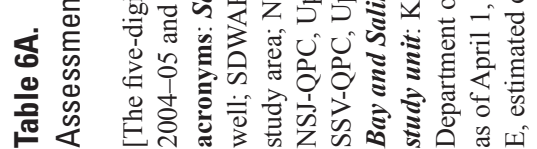

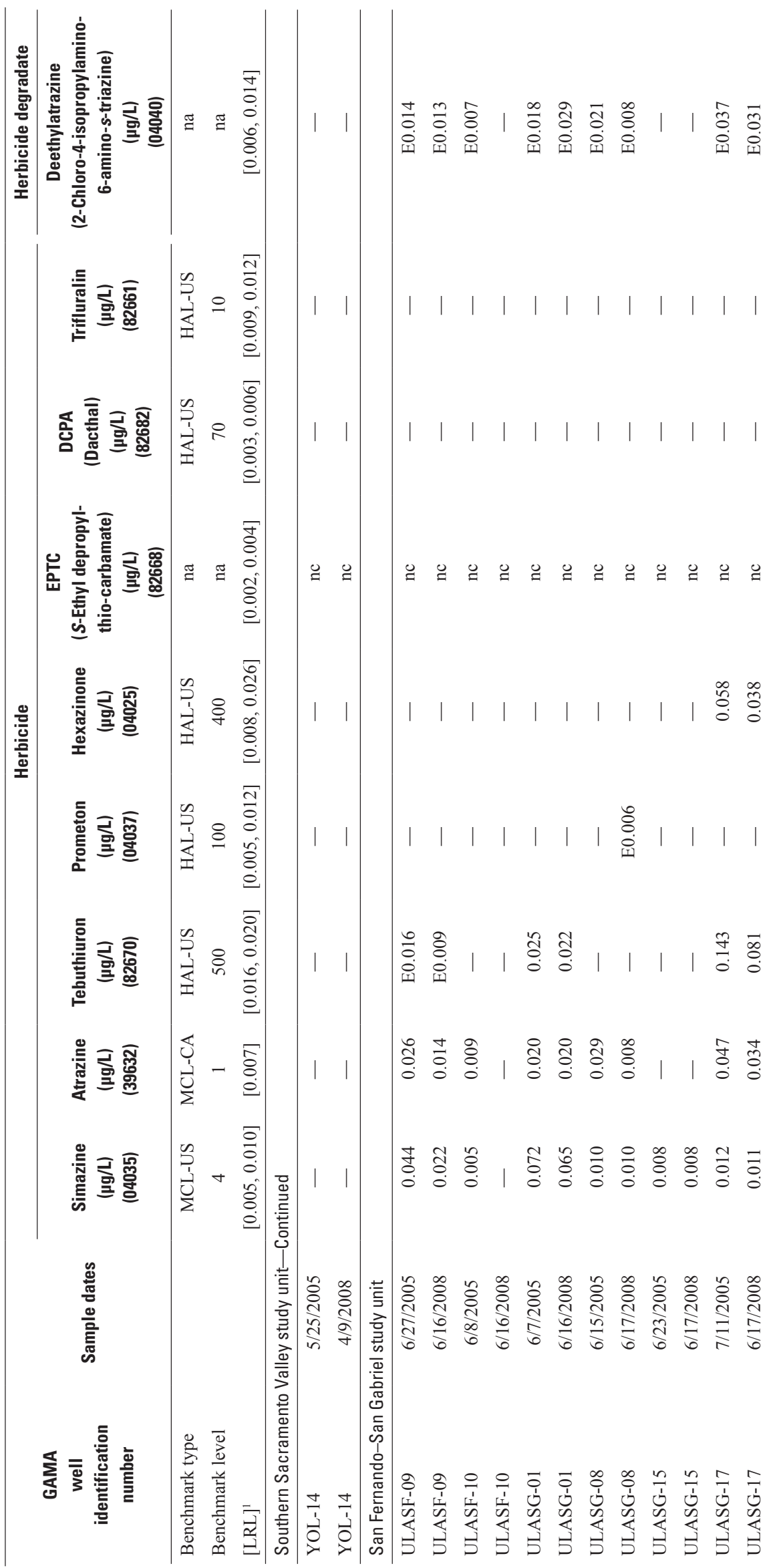




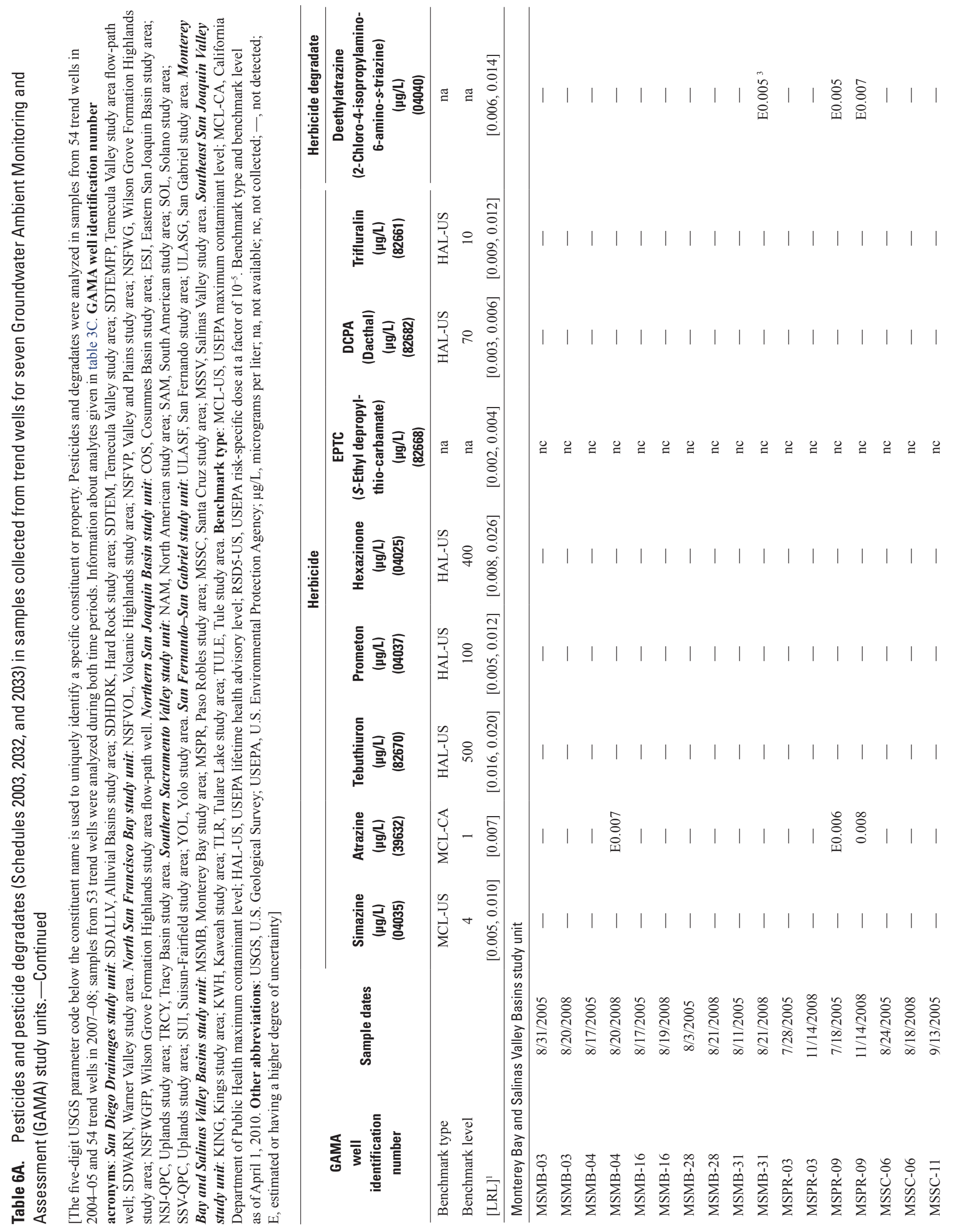



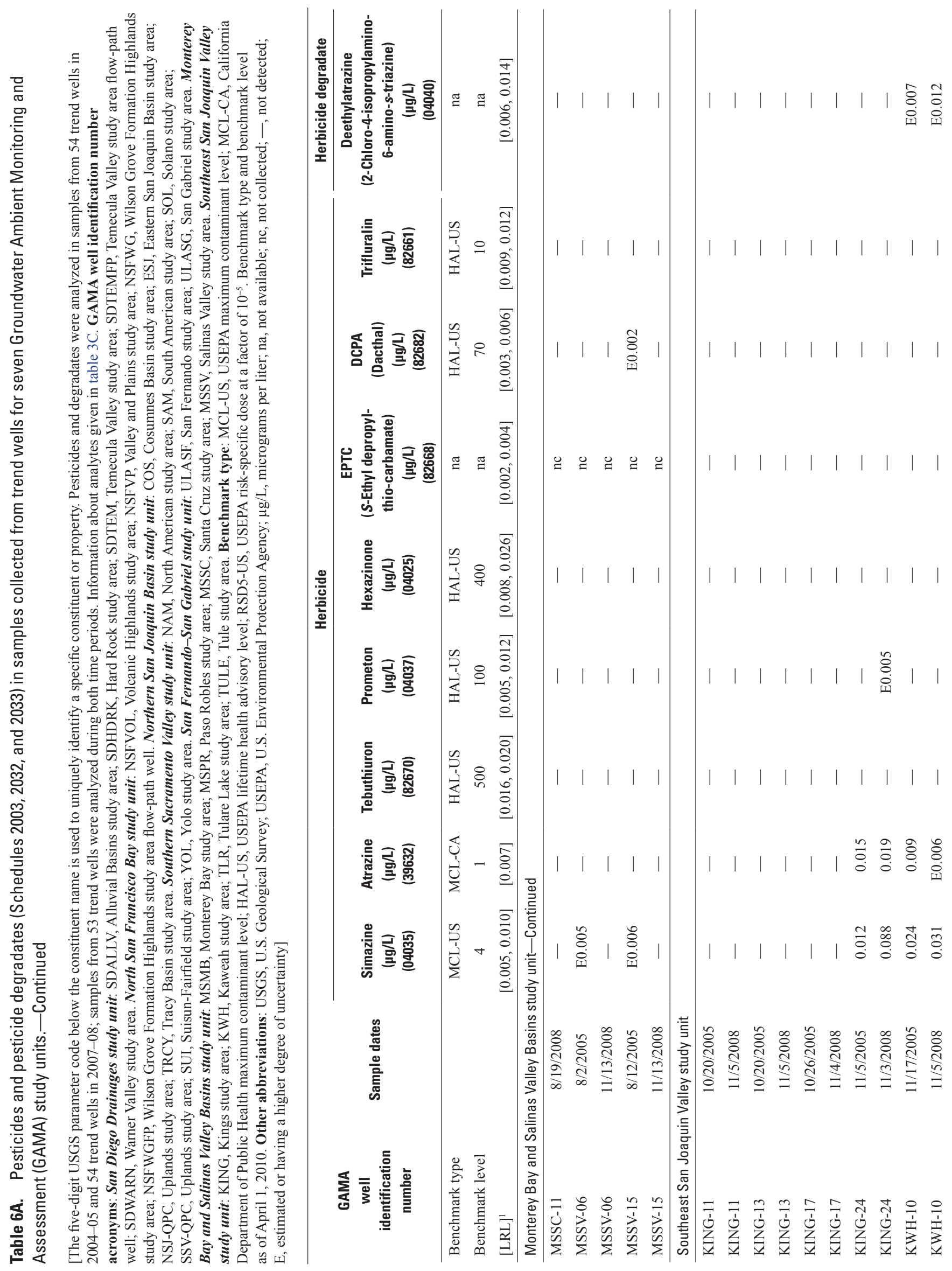


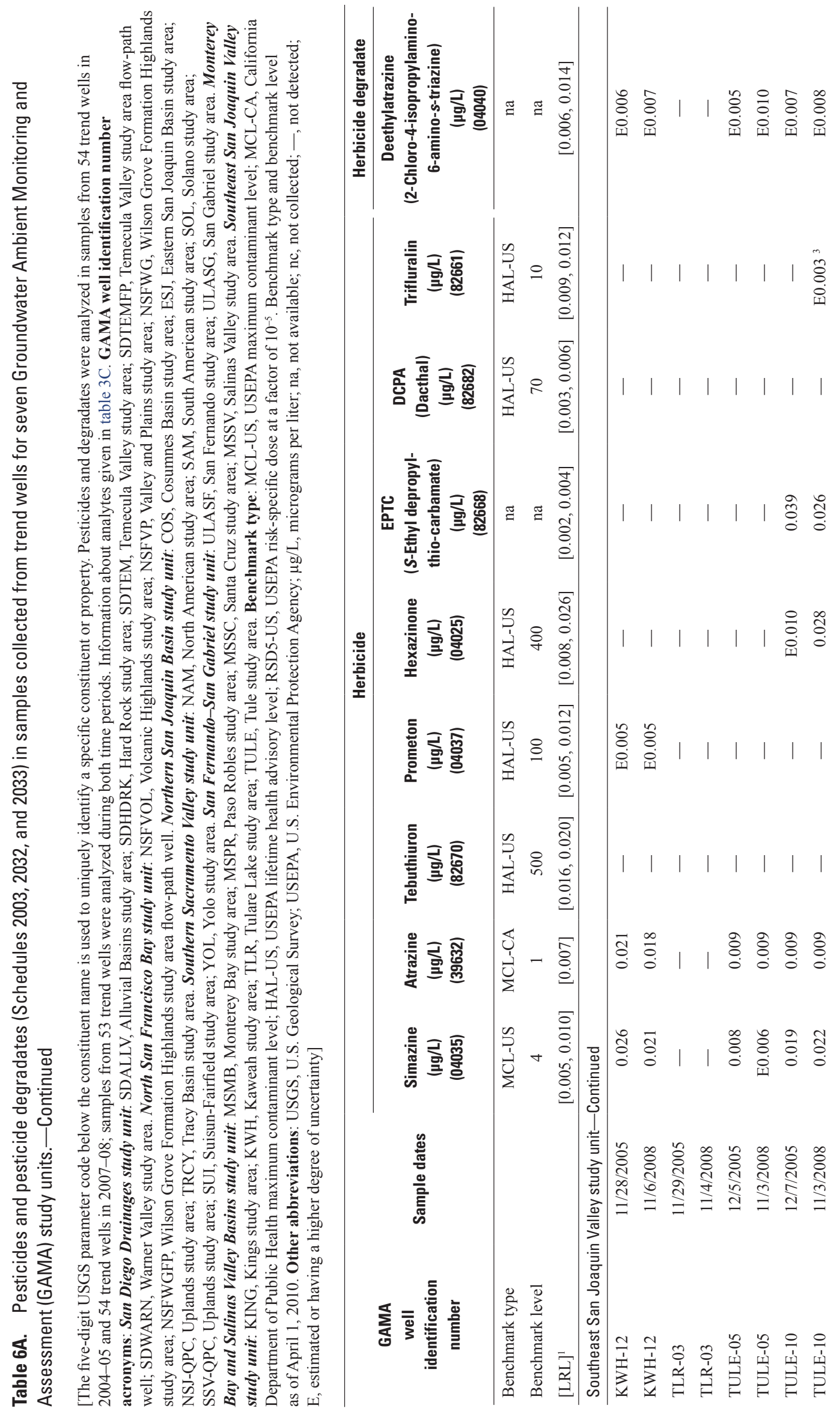



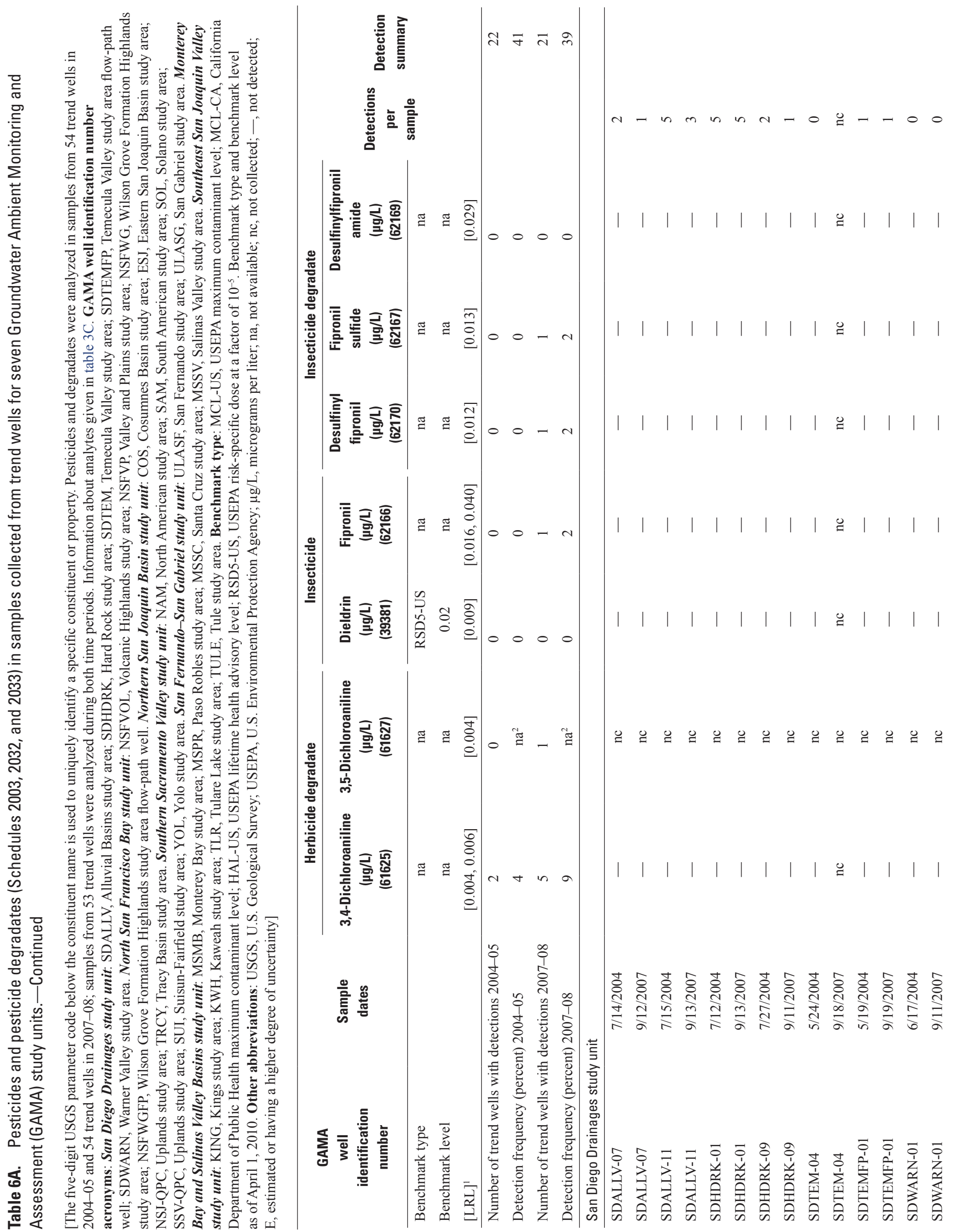


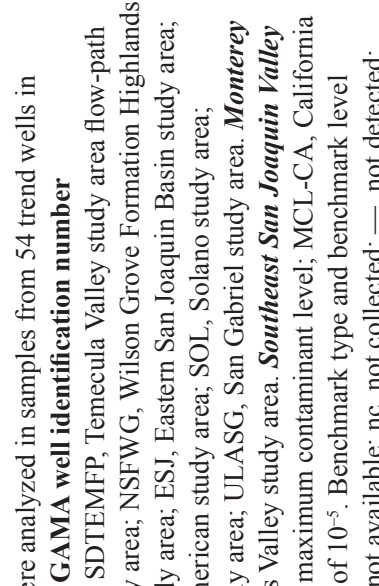

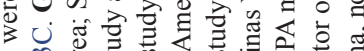

过记

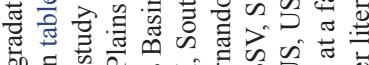
50

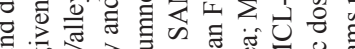

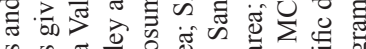

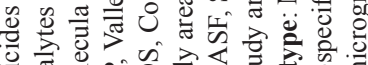

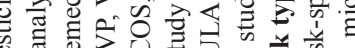

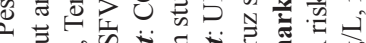

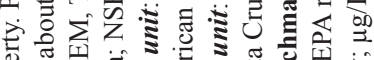

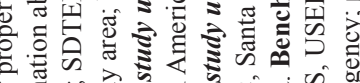

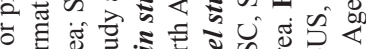

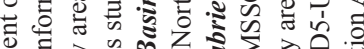

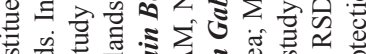

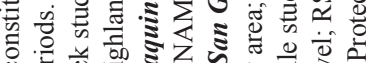

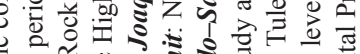

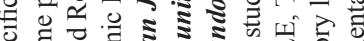

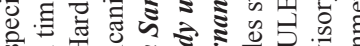

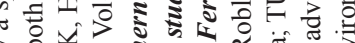

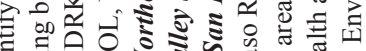

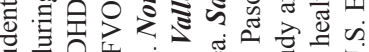

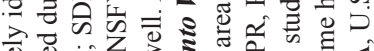

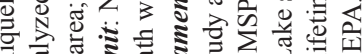

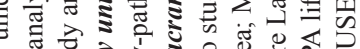

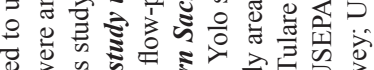

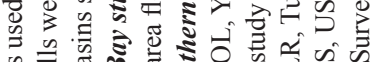

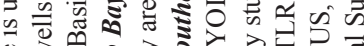

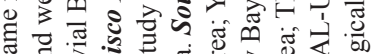
ज

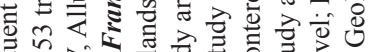
证

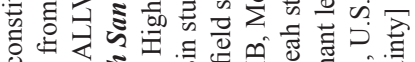

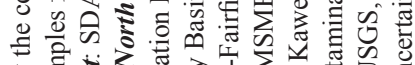

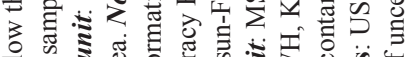

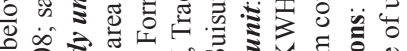

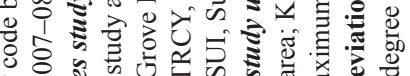

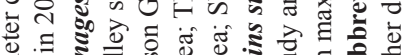

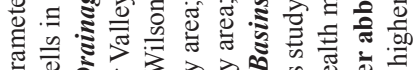

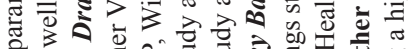

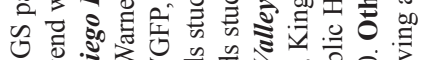
n

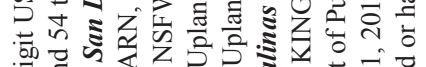

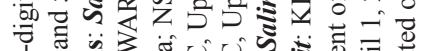

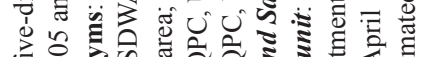

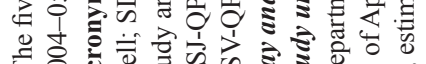

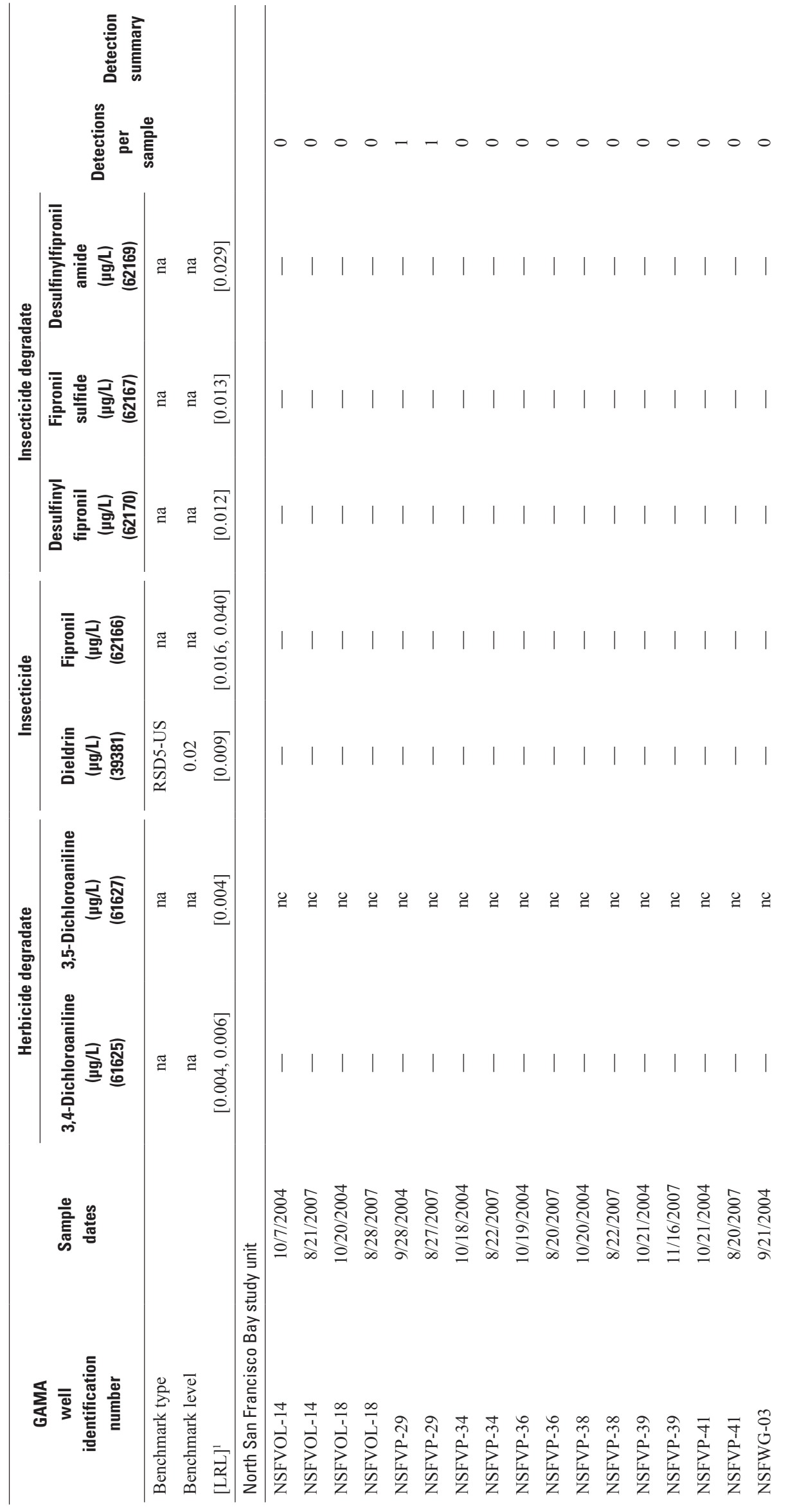



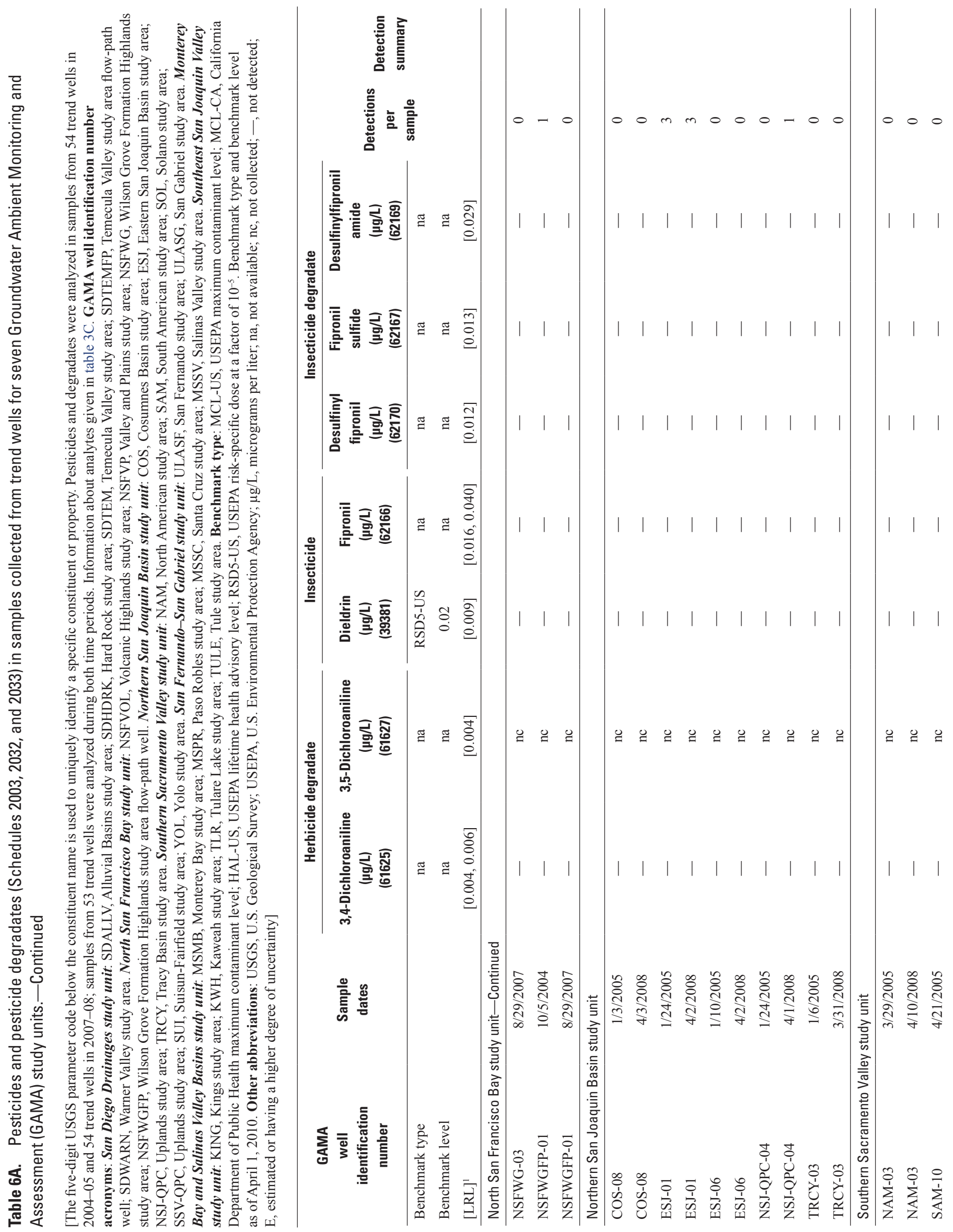


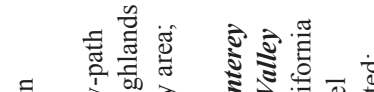

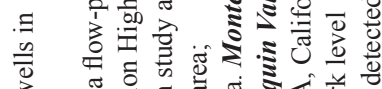

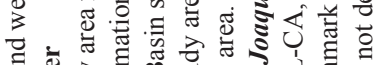

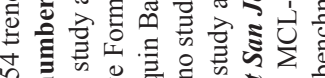

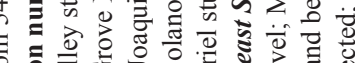

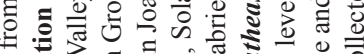

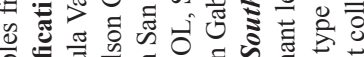

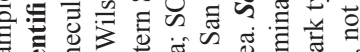

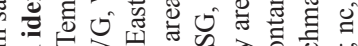

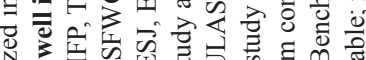

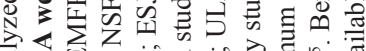

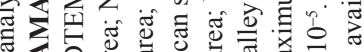

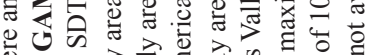

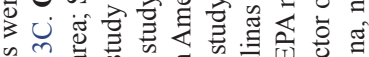

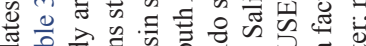

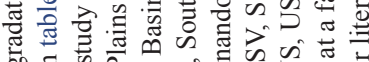
5.

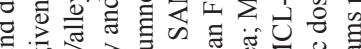

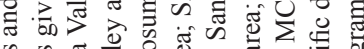

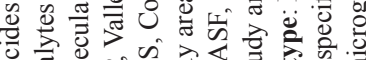

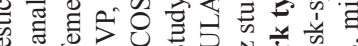
$\therefore$ 至

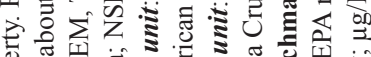

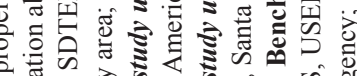

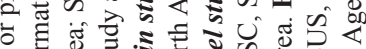

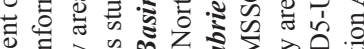
ज ج

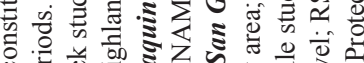

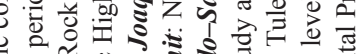

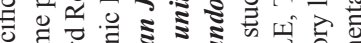

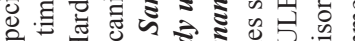

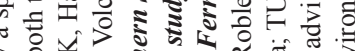

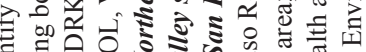
目金定

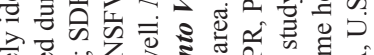

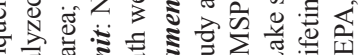

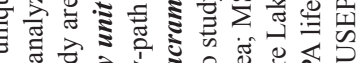

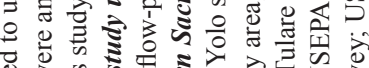
o 0

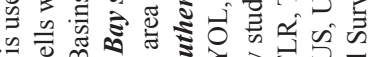

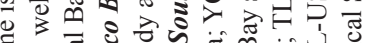

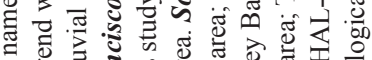

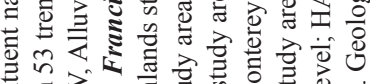

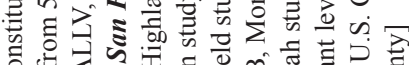

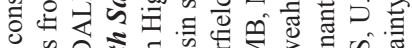

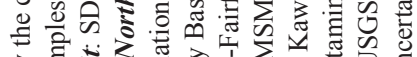

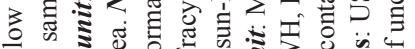

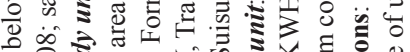

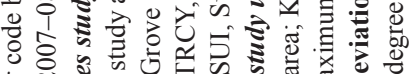
讨

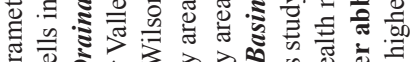

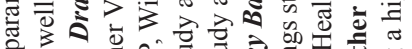

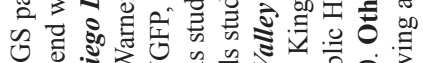
n

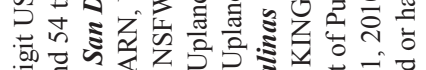

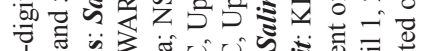

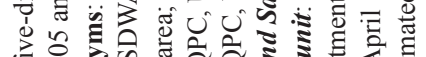

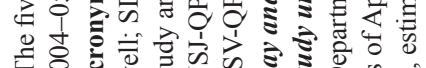

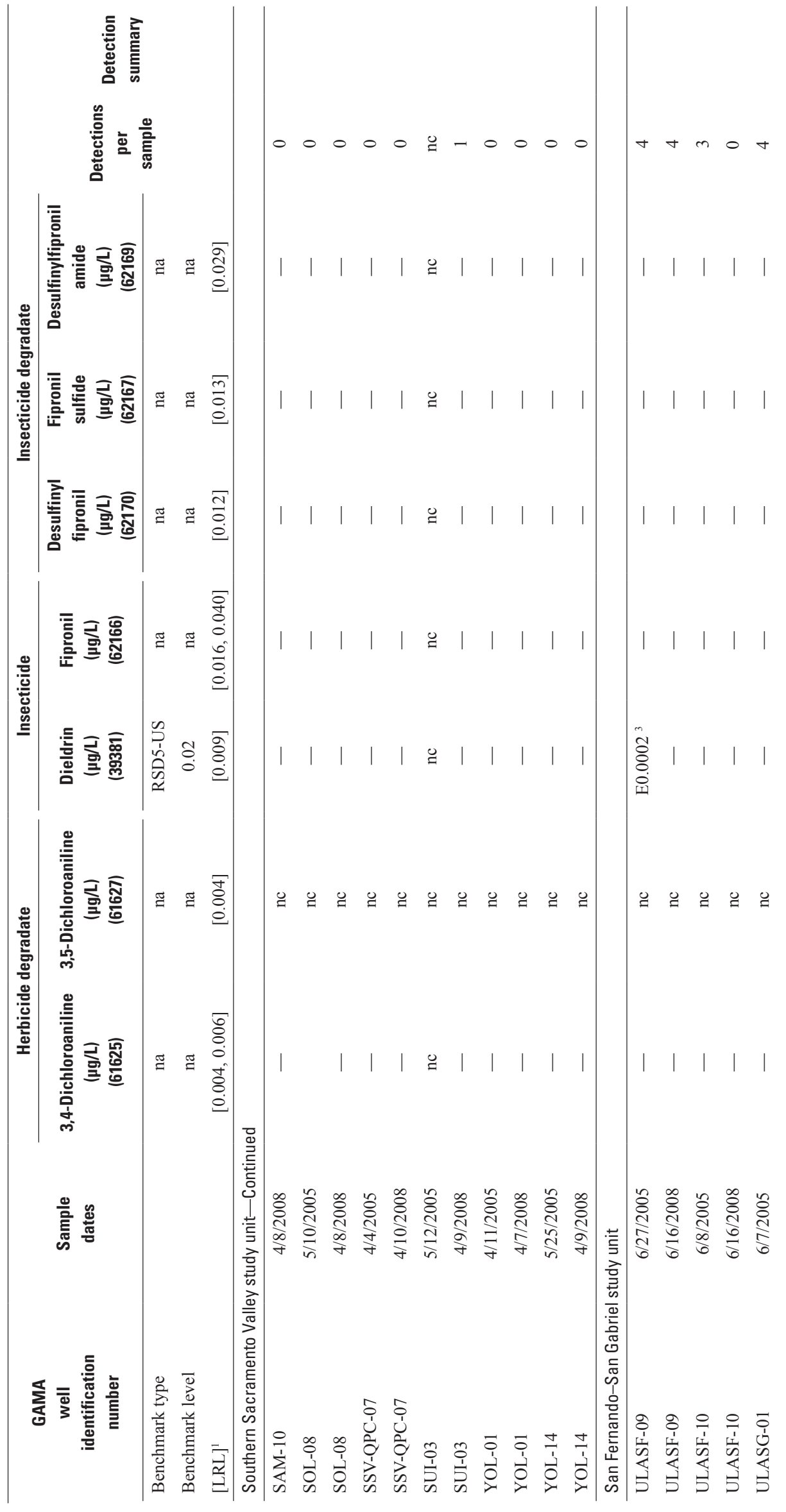


Tables 101
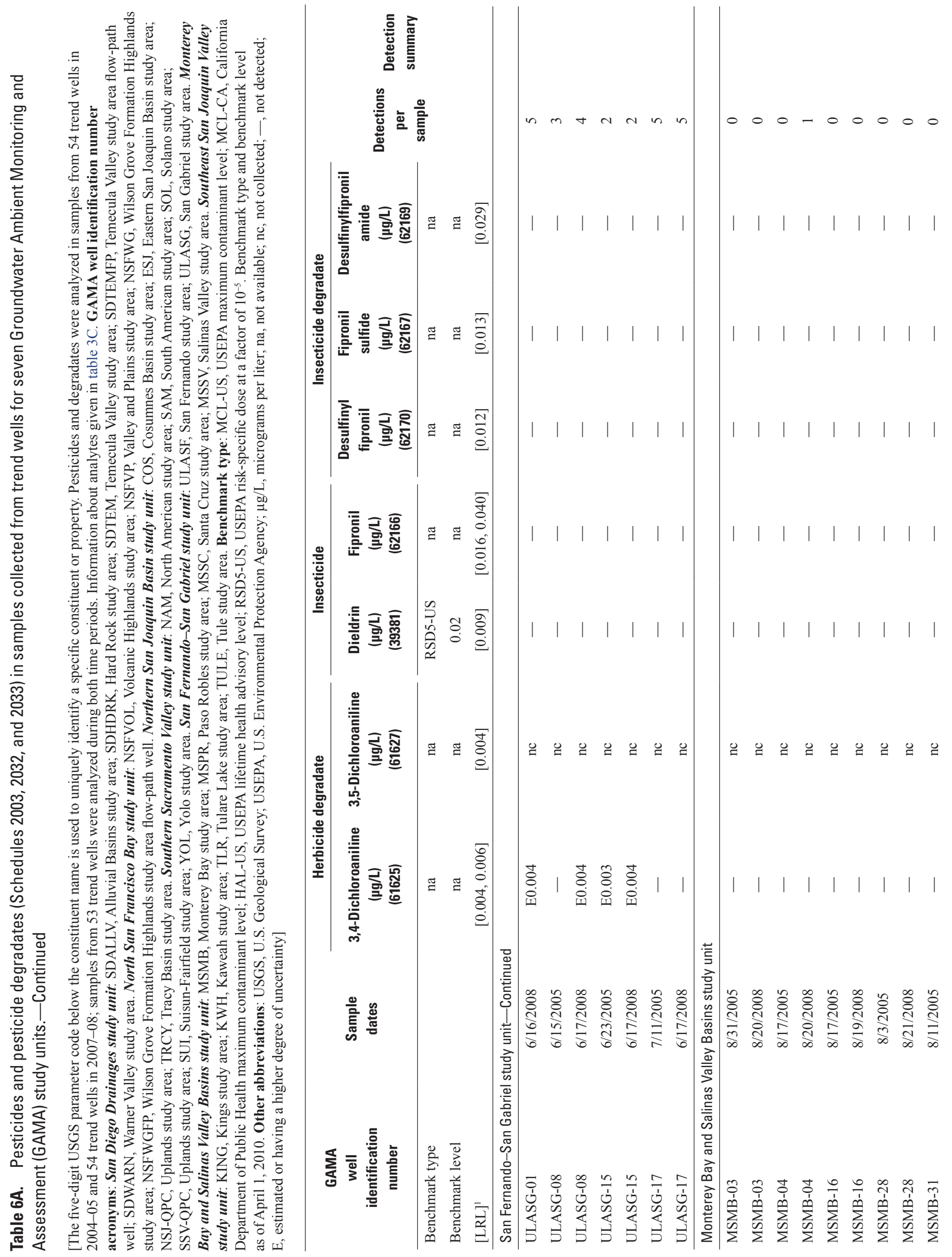


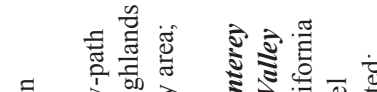

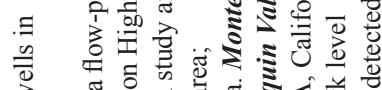

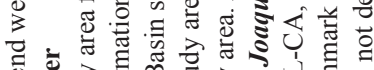

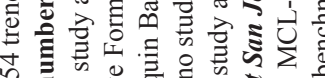

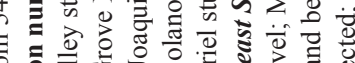

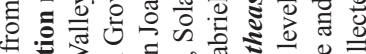
पु

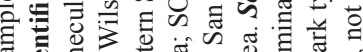

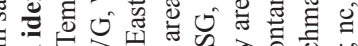

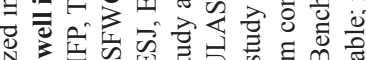

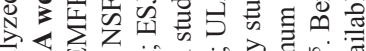

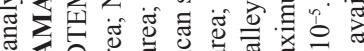

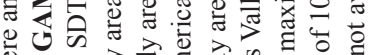

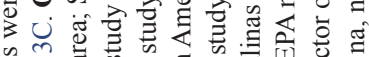

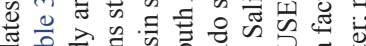

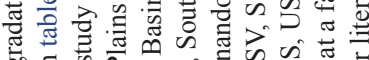
so

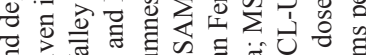

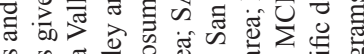

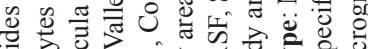

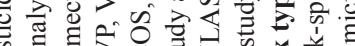

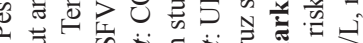

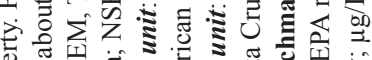

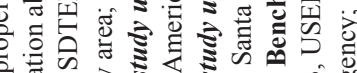

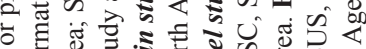

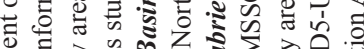
ज ج

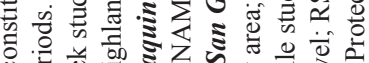

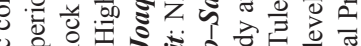

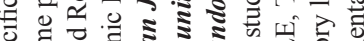

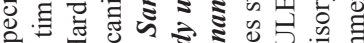

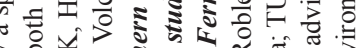

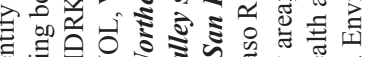

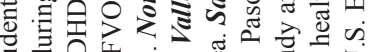

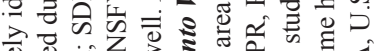

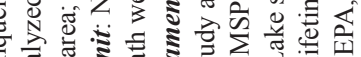

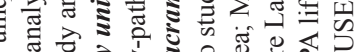

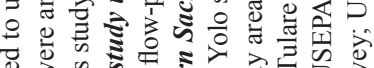
वृ

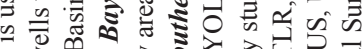

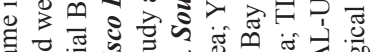

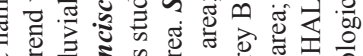

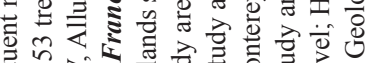

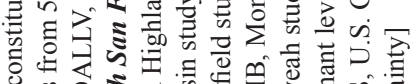

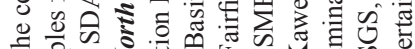

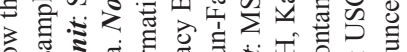

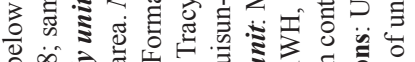
。ํำ

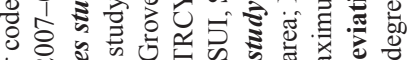
ป 공

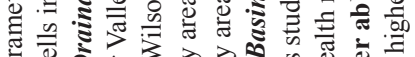
政 可

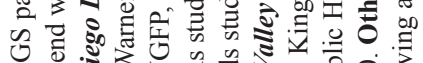
n

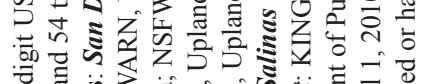
गे हैं

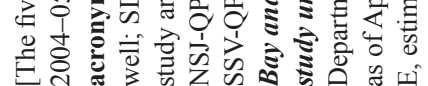

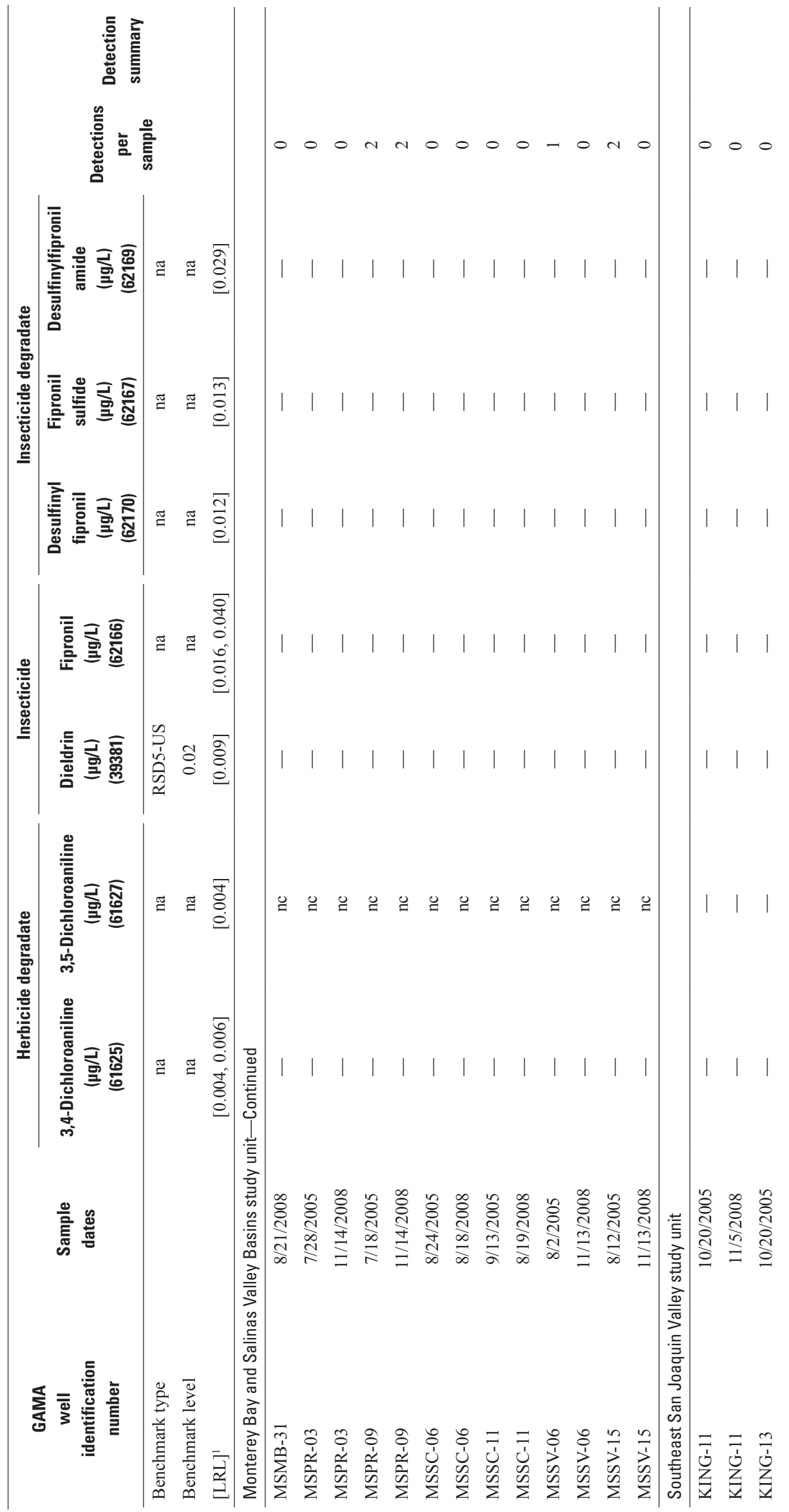



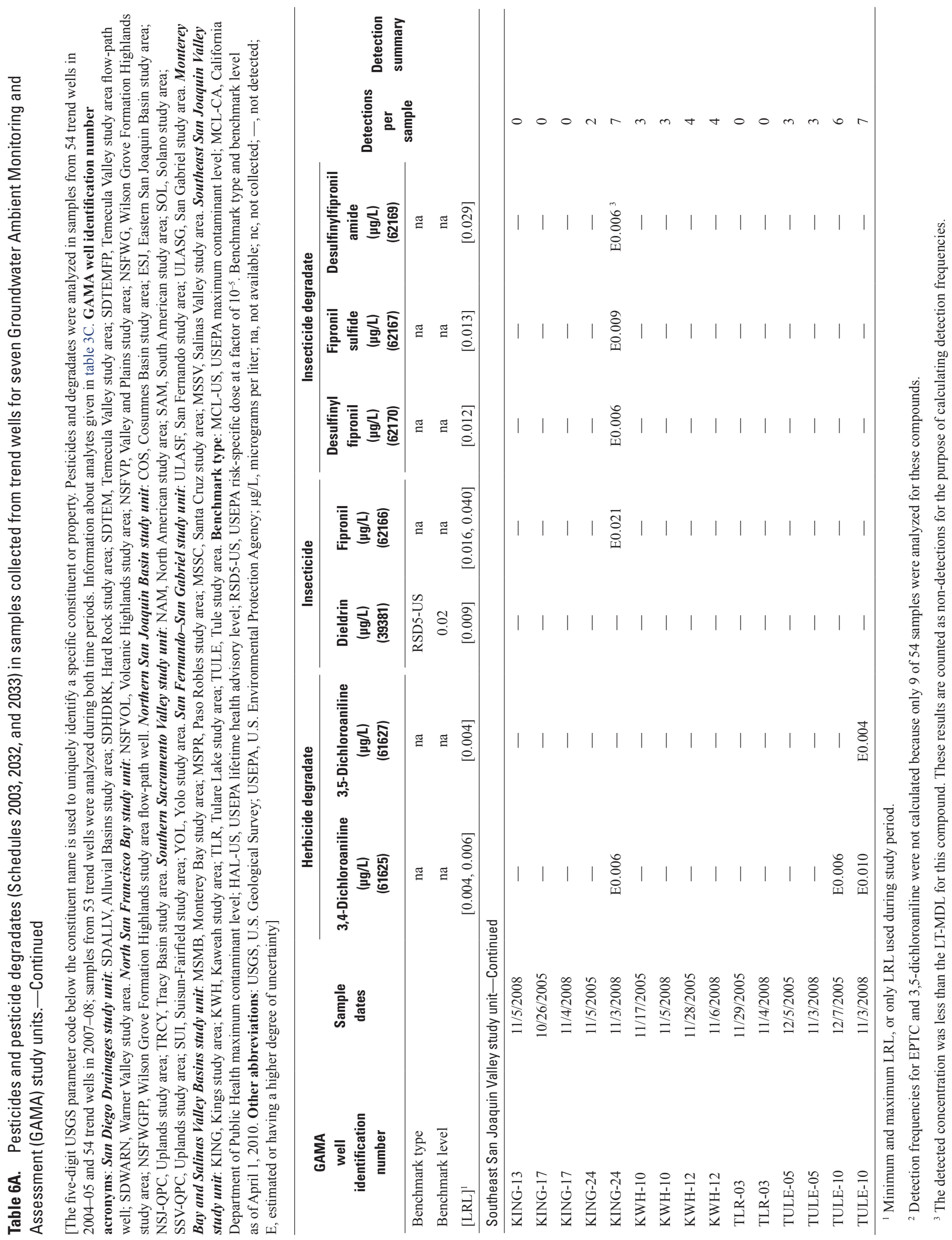

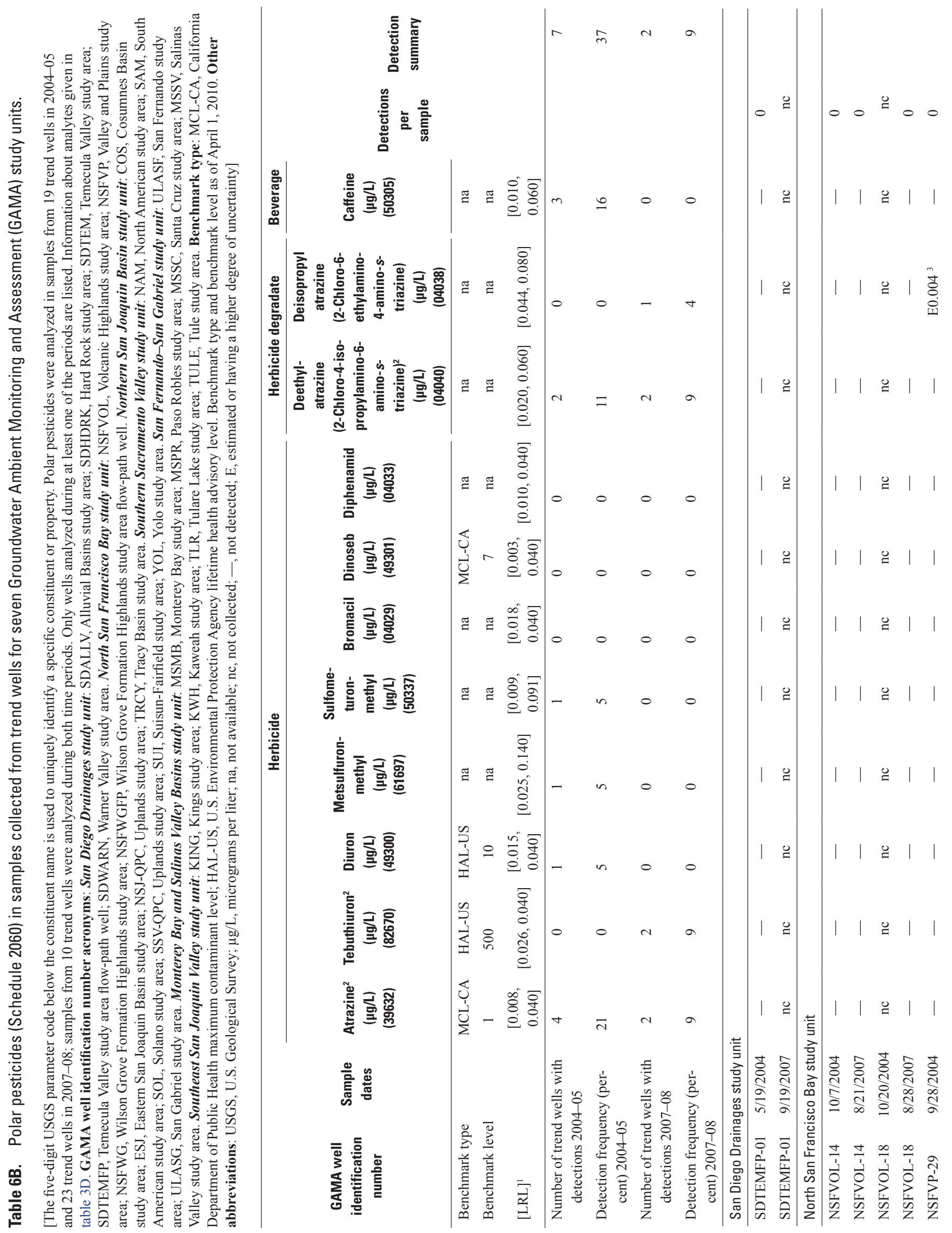
Tables 105
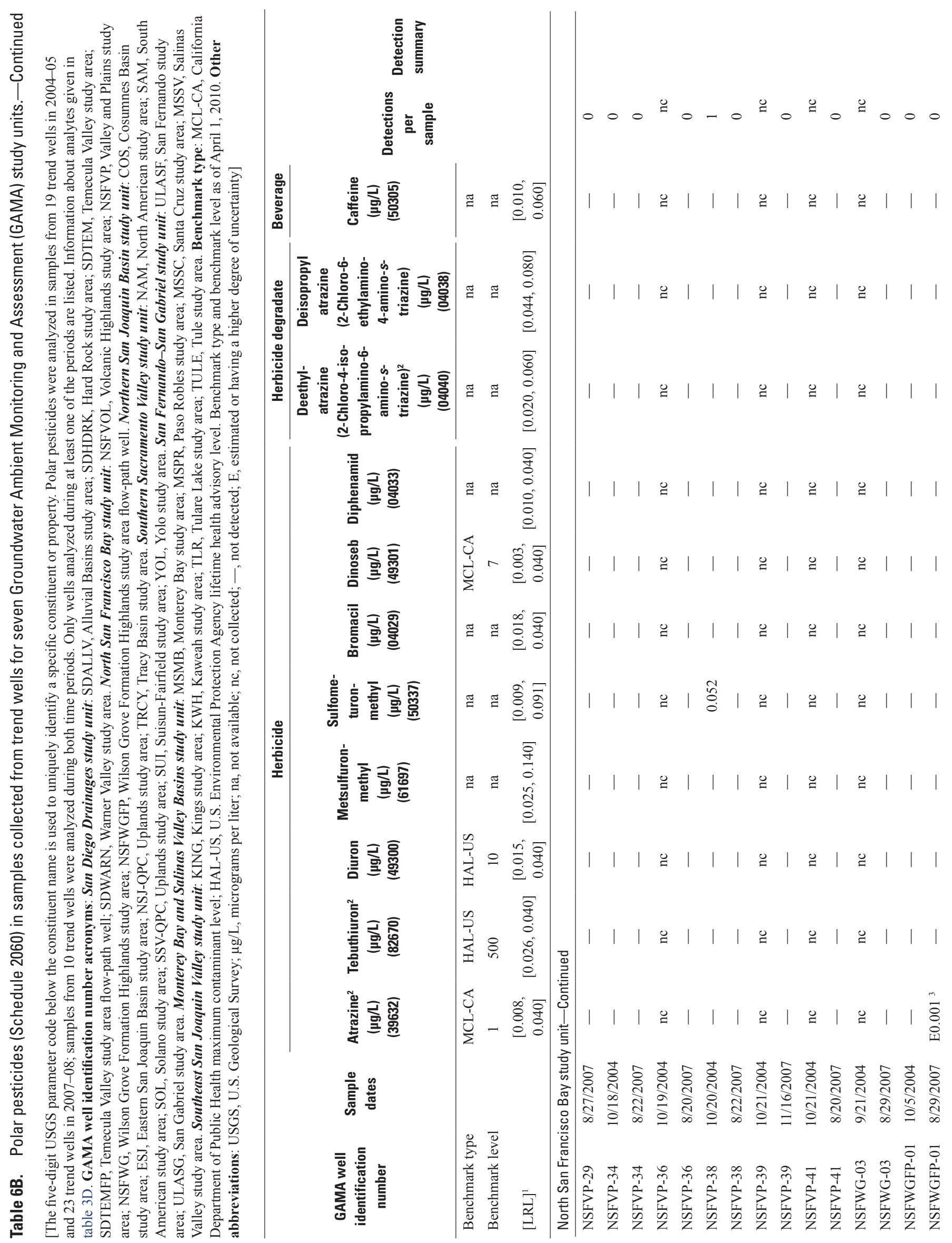

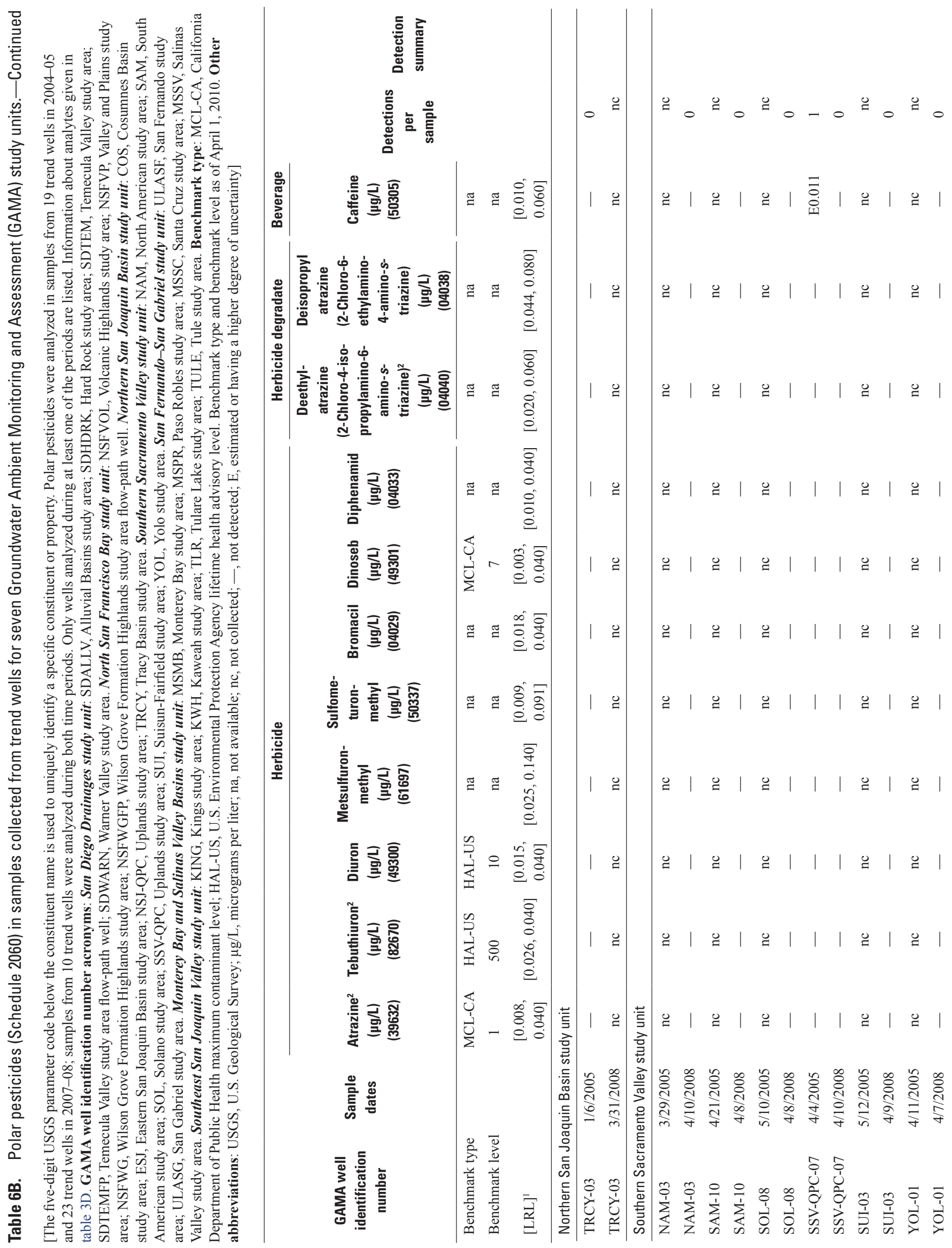
Tables 107
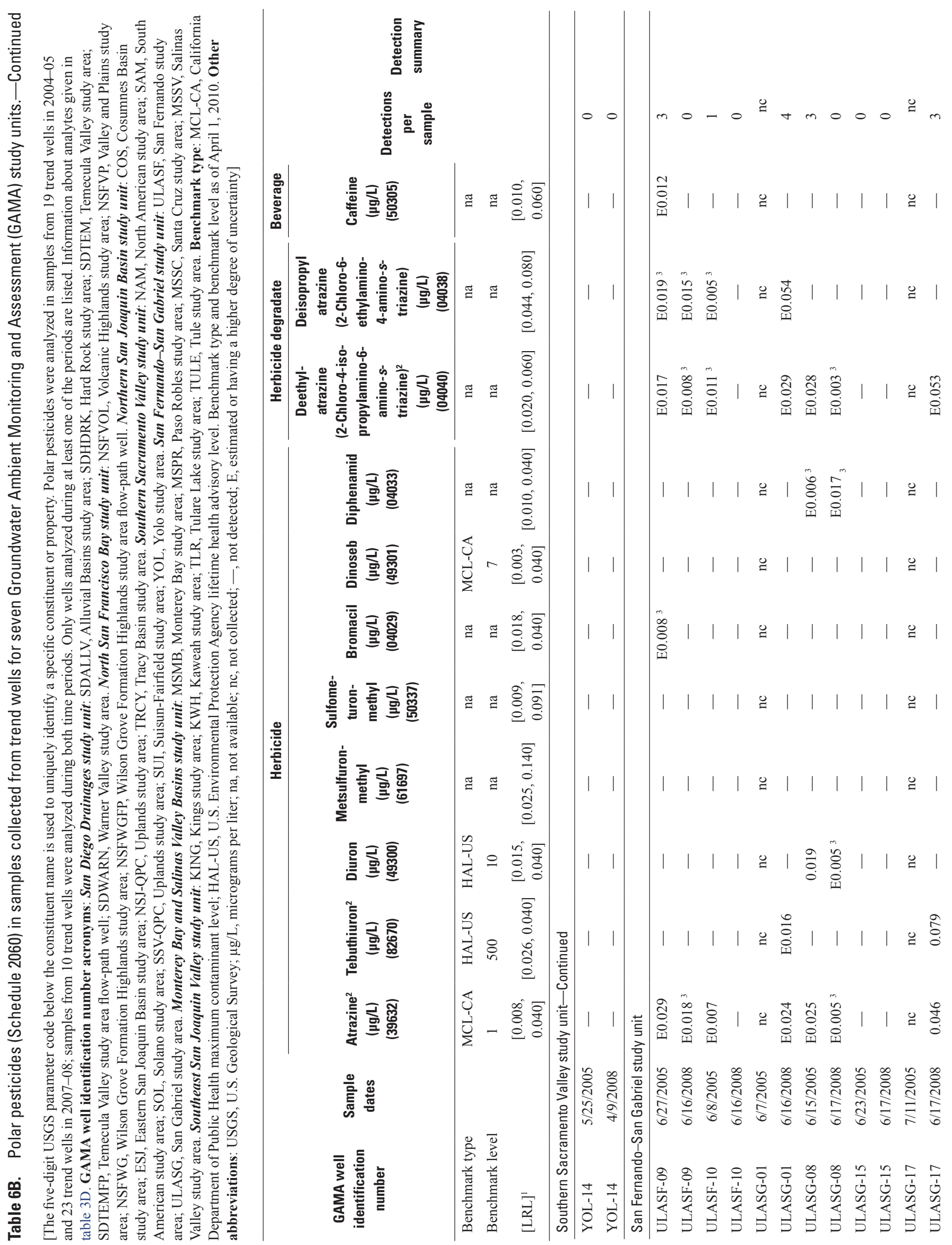

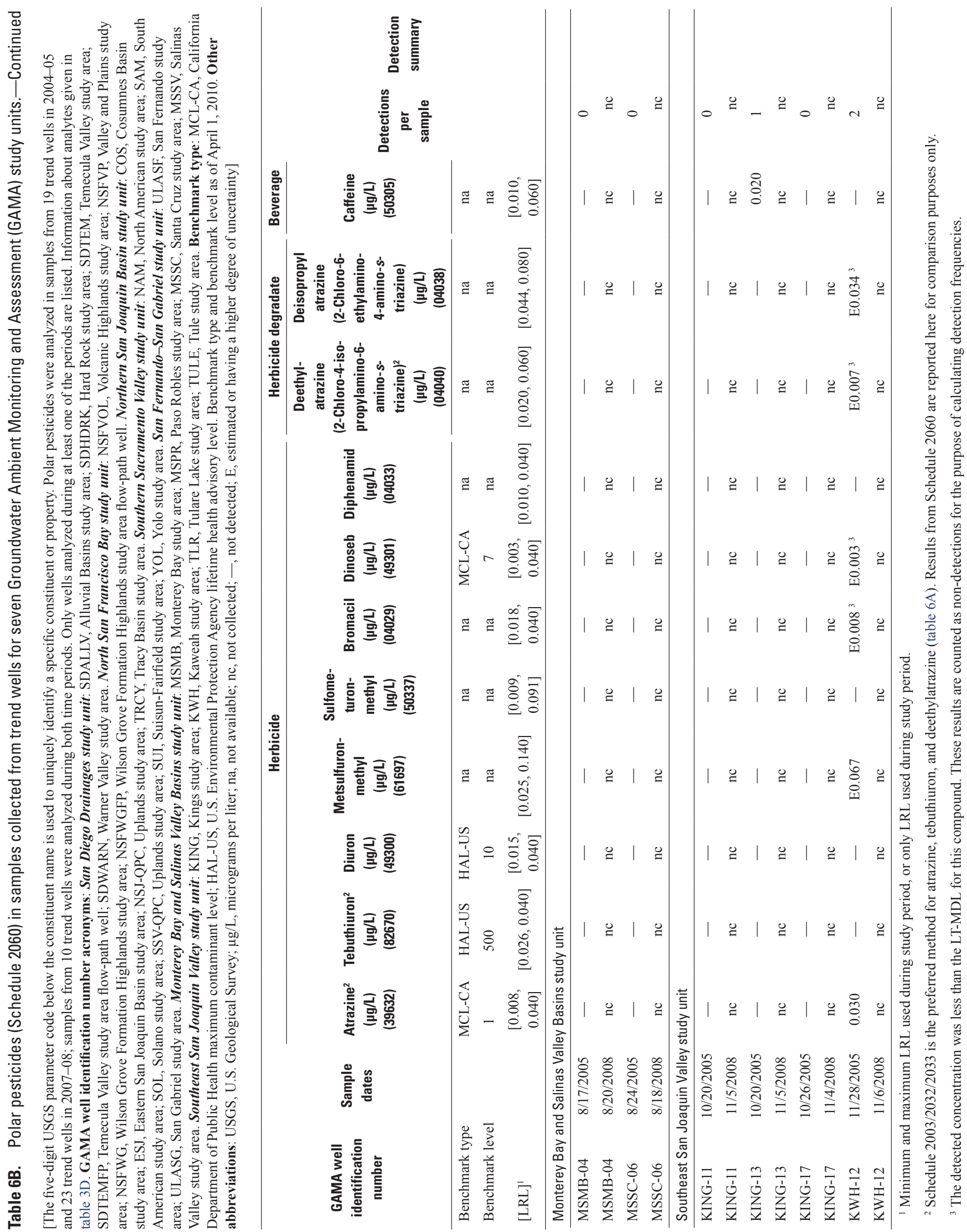
Table 7. Constituents of special interest in samples collected from trend wells sampled for seven Groundwater Ambient Monitoring and Assessment (GAMA) study units.

[The five-digit USGS parameter code below the constituent name is used to uniquely identify a specific constituent or property. Perchlorate was analyzed in samples from 36 trend wells during 2004-05 and 55 trend wells in 2007-08. NDMA was analyzed in 31 wells during 2004-05 and 17 wells in 2007-08; 6 wells were analyzed during both periods. 1,2,3-Trichloropropane was analyzed in 25 wells during 2004-05 and 38 wells during 2007-08; 15 wells were analyzed during both periods. Information about analytes given in table 3H. GAMA well identification number acronyms: San Diego Drainages study unit: SDALLV, Alluvial Basins study area; SDHDRK, Hard Rock study area; SDTEM, Temecula Valley study area; SDTEMFP, Temecula Valley study area flow-path well; SDWARN, Warner Valley study area. North San Francisco Bay study unit: NSFVOL, Volcanic Highlands study area; NSFVP, Valley and Plains study area; NSFWG, Wilson Grove Formation Highlands study area; NSFWGFP, Wilson Grove Formation Highlands study area flow-path well. Northern San Joaquin Basin study unit: COS, Cosumnes Basin study area; ESJ, Eastern San Joaquin Basin study area; NSJ-QPC, Uplands study area; TRCY, Tracy Basin study area. Southern Sacramento Valley study unit: NAM, North American study area; SAM, South American study area; SOL, Solano study area; SSV-QPC, Uplands study area; SUI, Suisun-Fairfield study area; YOL, Yolo study area. San Fernando-San Gabriel study unit: ULASF, San Fernando study area; ULASG, San Gabriel study area. Monterey Bay and Salinas Valley Basins study unit: MSMB, Monterey Bay study area; MSPR, Paso Robles study area; MSSC, Santa Cruz study area; MSSV, Salinas Valley study area. Southeast San Joaquin Valley study unit: KING, Kings study area; KWH, Kaweah study area; TLR, Tulare Lake study area; TULE, Tule study area. Benchmark type: HAL-US, U.S. Environmental Protection Agency lifetime health advisory level; NL-CA, CDPH notification level; MCL-CA, CDPH maximum contaminant level. Benchmark type and benchmark level as of April 1, 2010. Other abbreviations: USGS, U.S. Geological Survey; CDPH, California Department of Public Health; $\mu \mathrm{g} / \mathrm{L}$, micrograms per liter; LRL, laboratory reporting level; MRL, minimum reporting level; *, value greater than benchmark level; — not detected; <, less than; nc, not collected]

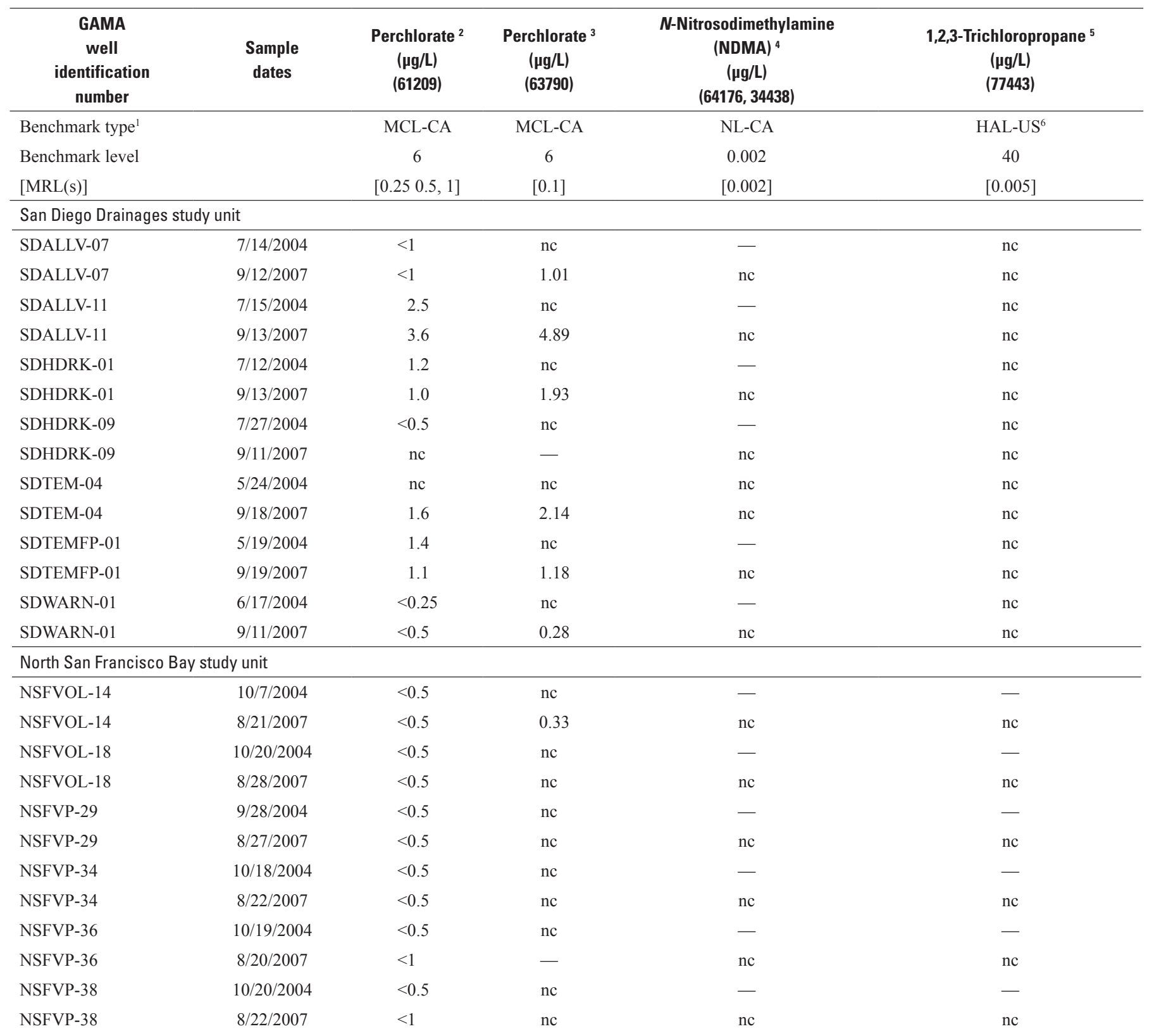


Table 7. Constituents of special interest in samples collected from trend wells sampled for seven Groundwater Ambient Monitoring and Assessment (GAMA) study units. - Continued

[The five-digit USGS parameter code below the constituent name is used to uniquely identify a specific constituent or property. Perchlorate was analyzed in samples from 36 trend wells during 2004-05 and 55 trend wells in 2007-08. NDMA was analyzed in 31 wells during 2004-05 and 17 wells in 2007-08; 6 wells were analyzed during both periods. 1,2,3-Trichloropropane was analyzed in 25 wells during 2004-05 and 38 wells during 2007-08; 15 wells were analyzed during both periods. Information about analytes given in table 3H. GAMA well identification number acronyms: San Diego Drainages study unit: SDALLV, Alluvial Basins study area; SDHDRK, Hard Rock study area; SDTEM, Temecula Valley study area; SDTEMFP, Temecula Valley study area flow-path well; SDWARN, Warner Valley study area. North San Francisco Bay study unit: NSFVOL, Volcanic Highlands study area; NSFVP, Valley and Plains study area; NSFWG, Wilson Grove Formation Highlands study area; NSFWGFP, Wilson Grove Formation Highlands study area flow-path well. Northern San Joaquin Basin study unit: COS, Cosumnes Basin study area; ESJ, Eastern San Joaquin Basin study area; NSJ-QPC, Uplands study area; TRCY, Tracy Basin study area. Southern Sacramento Valley study unit: NAM, North American study area; SAM, South American study area; SOL, Solano study area; SSV-QPC, Uplands study area; SUI, Suisun-Fairfield study area; YOL, Yolo study area. San Fernando-San Gabriel study unit: ULASF, San Fernando study area; ULASG, San Gabriel study area. Monterey Bay and Salinas Valley Basins study unit: MSMB, Monterey Bay study area; MSPR, Paso Robles study area; MSSC, Santa Cruz study area; MSSV, Salinas Valley study area. Southeast San Joaquin Valley study unit: KING, Kings study area; KWH, Kaweah study area; TLR, Tulare Lake study area; TULE, Tule study area. Benchmark type: HAL-US, U.S. Environmental Protection Agency lifetime health advisory level; NL-CA, CDPH notification level; MCL-CA, CDPH maximum contaminant level. Benchmark type and benchmark level as of April 1, 2010. Other abbreviations: USGS, U.S. Geological Survey; CDPH, California Department of Public Health; $\mu \mathrm{g} / \mathrm{L}$, micrograms per liter; LRL, laboratory reporting level; MRL, minimum reporting level; *, value greater than benchmark level; — not detected; <, less than; nc, not collected]

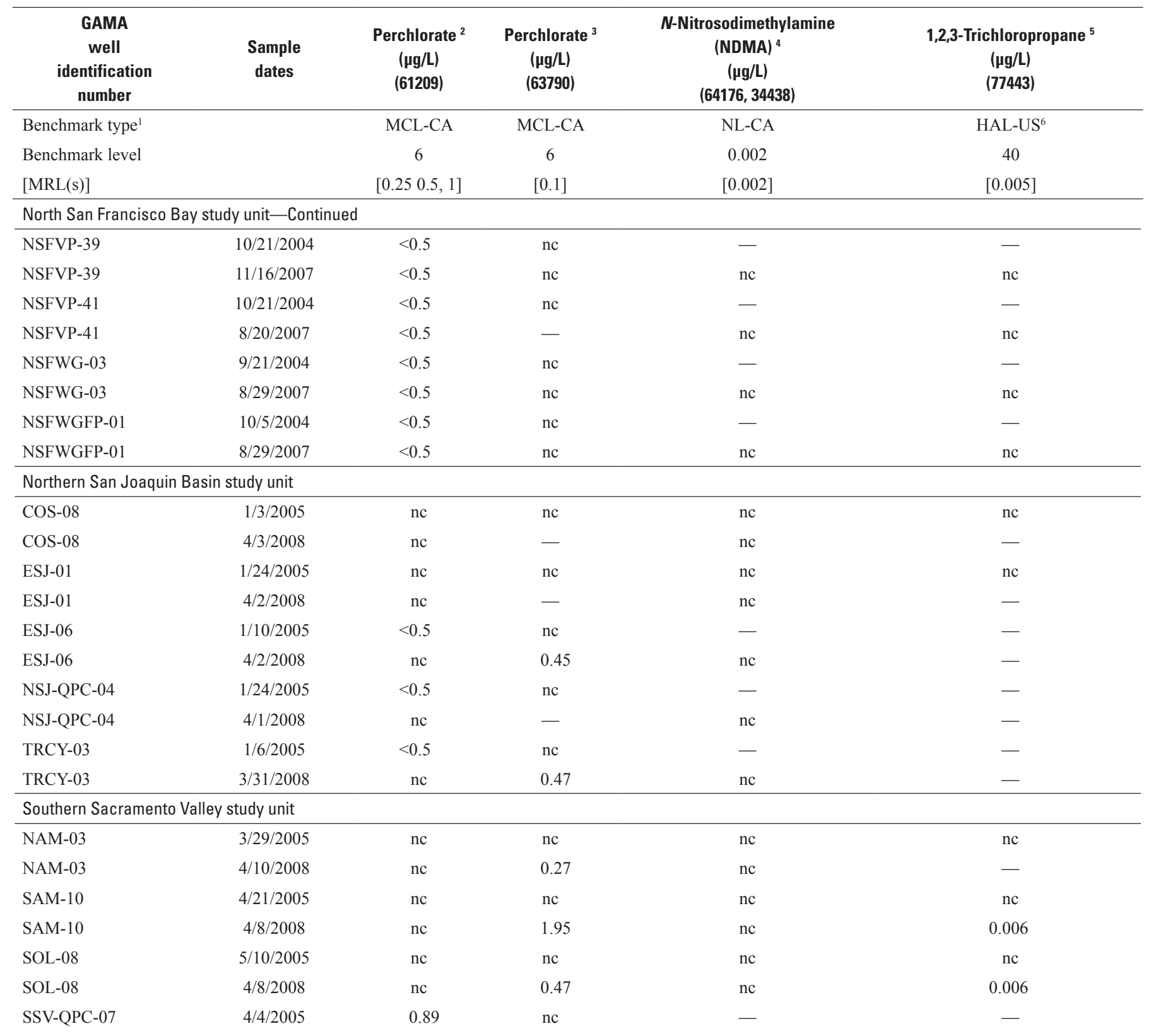


Table 7. Constituents of special interest in samples collected from trend wells sampled for seven Groundwater Ambient Monitoring and Assessment (GAMA) study units. - Continued

[The five-digit USGS parameter code below the constituent name is used to uniquely identify a specific constituent or property. Perchlorate was analyzed in samples from 36 trend wells during 2004-05 and 55 trend wells in 2007-08. NDMA was analyzed in 31 wells during 2004-05 and 17 wells in 2007-08; 6 wells were analyzed during both periods. 1,2,3-Trichloropropane was analyzed in 25 wells during 2004-05 and 38 wells during 2007-08; 15 wells were analyzed during both periods. Information about analytes given in table 3H. GAMA well identification number acronyms: San Diego Drainages study unit: SDALLV, Alluvial Basins study area; SDHDRK, Hard Rock study area; SDTEM, Temecula Valley study area; SDTEMFP, Temecula Valley study area flow-path well; SDWARN, Warner Valley study area. North San Francisco Bay study unit: NSFVOL, Volcanic Highlands study area; NSFVP, Valley and Plains study area; NSFWG, Wilson Grove Formation Highlands study area; NSFWGFP, Wilson Grove Formation Highlands study area flow-path well. Northern San Joaquin Basin study unit: COS, Cosumnes Basin study area; ESJ, Eastern San Joaquin Basin study area; NSJ-QPC, Uplands study area; TRCY, Tracy Basin study area. Southern Sacramento Valley study unit: NAM, North American study area; SAM, South American study area; SOL, Solano study area; SSV-QPC, Uplands study area; SUI, Suisun-Fairfield study area; YOL, Yolo study area. San Fernando-San Gabriel study unit: ULASF, San Fernando study area; ULASG, San Gabriel study area. Monterey Bay and Salinas Valley Basins study unit: MSMB, Monterey Bay study area; MSPR, Paso Robles study area; MSSC, Santa Cruz study area; MSSV, Salinas Valley study area. Southeast San Joaquin Valley study unit: KING, Kings study area; KWH, Kaweah study area; TLR, Tulare Lake study area; TULE, Tule study area. Benchmark type: HAL-US, U.S. Environmental Protection Agency lifetime health advisory level; NL-CA, CDPH notification level; MCL-CA, CDPH maximum contaminant level. Benchmark type and benchmark level as of April 1, 2010. Other abbreviations: USGS, U.S. Geological Survey; CDPH, California Department of Public Health; $\mu \mathrm{g} / \mathrm{L}$, micrograms per liter; LRL, laboratory reporting level; MRL, minimum reporting level; *, value greater than benchmark level; — not detected; <, less than; nc, not collected]

\begin{tabular}{|c|c|c|c|c|c|}
\hline $\begin{array}{c}\text { GAMA } \\
\text { well } \\
\text { identification } \\
\text { number }\end{array}$ & $\begin{array}{c}\text { Sample } \\
\text { dates }\end{array}$ & $\begin{array}{c}\text { Perchlorate }{ }^{2} \\
\quad(\mu \mathrm{g} / \mathrm{L}) \\
(61209)\end{array}$ & $\begin{array}{c}\text { Perchlorate }{ }^{3} \\
(\mu \mathrm{g} / \mathrm{L}) \\
(63790)\end{array}$ & $\begin{array}{c}N \text {-Nitrosodimethylamine } \\
(\text { NDMA })^{4} \\
(\mu \mathrm{g} / \mathrm{L}) \\
(64176,34438)\end{array}$ & $\begin{array}{c}\text { 1,2,3-Trichloropropane } \\
\text { ( } \mu \mathrm{g} / \mathrm{L}) \\
(77443)\end{array}$ \\
\hline Benchmark level & & 6 & 6 & 0.002 & 40 \\
\hline$[\mathrm{MRL}(\mathrm{s})]$ & & {$\left[\begin{array}{lll}0.25 & 0.5,1]\end{array}\right.$} & {$[0.1]$} & {$[0.002]$} & {$[0.005]$} \\
\hline SSV-QPC-07 & $4 / 10 / 2008$ & $\mathrm{nc}$ & 0.67 & $\mathrm{nc}$ & 0.005 \\
\hline SUI-03 & $5 / 12 / 2005$ & $\mathrm{nc}$ & $\mathrm{nc}$ & $\mathrm{nc}$ & $\mathrm{nc}$ \\
\hline SUI-03 & 4/9/2008 & $\mathrm{nc}$ & 0.9 & $\mathrm{nc}$ & - \\
\hline YOL-01 & $4 / 11 / 2005$ & $\mathrm{nc}$ & $\mathrm{nc}$ & $\mathrm{nc}$ & $\mathrm{nc}$ \\
\hline YOL-01 & $4 / 7 / 2008$ & $\mathrm{nc}$ & 0.56 & $\mathrm{nc}$ & 0.006 \\
\hline ULASF-09 & $6 / 27 / 2005$ & $<0.5$ & $\mathrm{nc}$ & - & - \\
\hline ULASF-09 & $6 / 16 / 2008$ & $\mathrm{nc}$ & 2.24 & - & - \\
\hline ULASF-10 & $6 / 8 / 2005$ & $<0.5$ & $\mathrm{nc}$ & - & - \\
\hline ULASF-10 & $6 / 16 / 2008$ & $\mathrm{nc}$ & - & - & - \\
\hline ULASG-01 & $6 / 7 / 2005$ & $\mathrm{nc}$ & $\mathrm{nc}$ & $\mathrm{nc}$ & $\mathrm{nc}$ \\
\hline ULASG-01 & $6 / 16 / 2008$ & $\mathrm{nc}$ & $* 7.77$ & - & - \\
\hline ULASG-08 & $6 / 15 / 2005$ & 3.8 & $\mathrm{nc}$ & - & - \\
\hline ULASG-08 & $6 / 17 / 2008$ & $\mathrm{nc}$ & 3.98 & - & - \\
\hline ULASG-15 & $6 / 23 / 2005$ & $<0.5$ & $\mathrm{nc}$ & - & - \\
\hline MSMB-04 & $8 / 17 / 2005$ & $<1$ & $\mathrm{nc}$ & - & - \\
\hline MSMB-04 & $8 / 20 / 2008$ & $\mathrm{nc}$ & - & - & - \\
\hline MSMB-16 & $8 / 17 / 2005$ & $\mathrm{nc}$ & $\mathrm{nc}$ & $\mathrm{nc}$ & $\mathrm{nc}$ \\
\hline MSMB-16 & $8 / 19 / 2008$ & $\mathrm{nc}$ & 0.50 & - & - \\
\hline
\end{tabular}


Table 7. Constituents of special interest in samples collected from trend wells sampled for seven Groundwater Ambient Monitoring and Assessment (GAMA) study units. - Continued

[The five-digit USGS parameter code below the constituent name is used to uniquely identify a specific constituent or property. Perchlorate was analyzed in samples from 36 trend wells during 2004-05 and 55 trend wells in 2007-08. NDMA was analyzed in 31 wells during 2004-05 and 17 wells in 2007-08; 6 wells were analyzed during both periods. 1,2,3-Trichloropropane was analyzed in 25 wells during 2004-05 and 38 wells during 2007-08; 15 wells were analyzed during both periods. Information about analytes given in table 3H. GAMA well identification number acronyms: San Diego Drainages study unit: SDALLV, Alluvial Basins study area; SDHDRK, Hard Rock study area; SDTEM, Temecula Valley study area; SDTEMFP, Temecula Valley study area flow-path well; SDWARN, Warner Valley study area. North San Francisco Bay study unit: NSFVOL, Volcanic Highlands study area; NSFVP, Valley and Plains study area; NSFWG, Wilson Grove Formation Highlands study area; NSFWGFP, Wilson Grove Formation Highlands study area flow-path well. Northern San Joaquin Basin study unit: COS, Cosumnes Basin study area; ESJ, Eastern San Joaquin Basin study area; NSJ-QPC, Uplands study area; TRCY, Tracy Basin study area. Southern Sacramento Valley study unit: NAM, North American study area; SAM, South American study area; SOL, Solano study area; SSV-QPC, Uplands study area; SUI, Suisun-Fairfield study area; YOL, Yolo study area. San Fernando-San Gabriel study unit: ULASF, San Fernando study area; ULASG, San Gabriel study area. Monterey Bay and Salinas Valley Basins study unit: MSMB, Monterey Bay study area; MSPR, Paso Robles study area; MSSC, Santa Cruz study area; MSSV, Salinas Valley study area. Southeast San Joaquin Valley study unit: KING, Kings study area; KWH, Kaweah study area; TLR, Tulare Lake study area; TULE, Tule study area. Benchmark type: HAL-US, U.S. Environmental Protection Agency lifetime health advisory level; NL-CA, CDPH notification level; MCL-CA, CDPH maximum contaminant level. Benchmark type and benchmark level as of April 1, 2010. Other abbreviations: USGS, U.S. Geological Survey; CDPH, California Department of Public Health; $\mu \mathrm{g} / \mathrm{L}$, micrograms per liter; LRL, laboratory reporting level; MRL, minimum reporting level; *, value greater than benchmark level; — not detected; <, less than; nc, not collected]

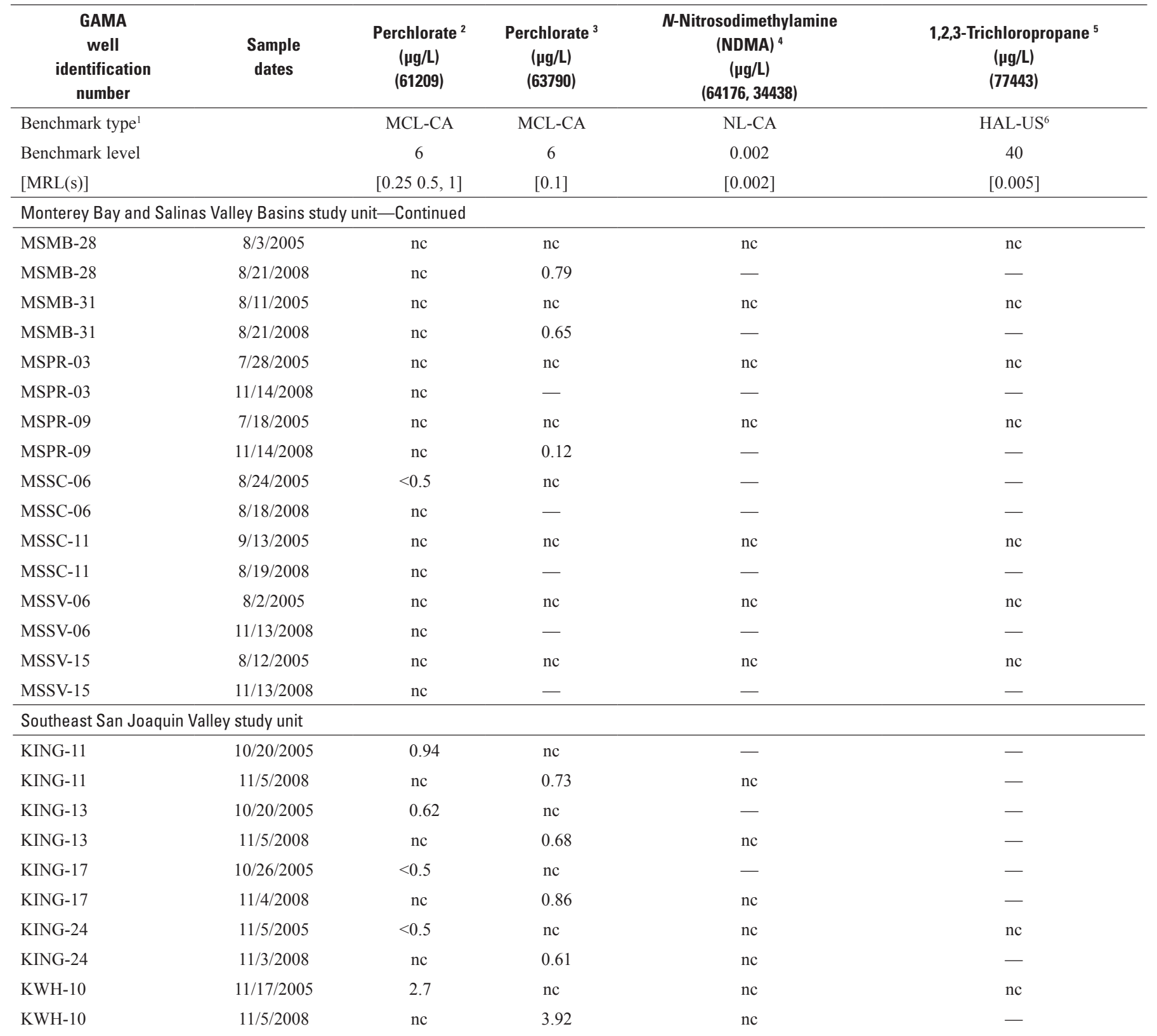


Table 7. Constituents of special interest in samples collected from trend wells sampled for seven Groundwater Ambient Monitoring and Assessment (GAMA) study units. - Continued

[The five-digit USGS parameter code below the constituent name is used to uniquely identify a specific constituent or property. Perchlorate was analyzed in samples from 36 trend wells during 2004-05 and 55 trend wells in 2007-08. NDMA was analyzed in 31 wells during 2004-05 and 17 wells in 2007-08; 6 wells were analyzed during both periods. 1,2,3-Trichloropropane was analyzed in 25 wells during 2004-05 and 38 wells during 2007-08; 15 wells were analyzed during both periods. Information about analytes given in table 3H. GAMA well identification number acronyms: San Diego Drainages study unit: SDALLV, Alluvial Basins study area; SDHDRK, Hard Rock study area; SDTEM, Temecula Valley study area; SDTEMFP, Temecula Valley study area flow-path well; SDWARN, Warner Valley study area. North San Francisco Bay study unit: NSFVOL, Volcanic Highlands study area; NSFVP, Valley and Plains study area; NSFWG, Wilson Grove Formation Highlands study area; NSFWGFP, Wilson Grove Formation Highlands study area flow-path well. Northern San Joaquin Basin study unit: COS, Cosumnes Basin study area; ESJ, Eastern San Joaquin Basin study area; NSJ-QPC, Uplands study area; TRCY, Tracy Basin study area. Southern Sacramento Valley study unit: NAM, North American study area; SAM, South American study area; SOL, Solano study area; SSV-QPC, Uplands study area; SUI, Suisun-Fairfield study area; YOL, Yolo study area. San Fernando-San Gabriel study unit: ULASF, San Fernando study area; ULASG, San Gabriel study area. Monterey Bay and Salinas Valley Basins study unit: MSMB, Monterey Bay study area; MSPR, Paso Robles study area; MSSC, Santa Cruz study area; MSSV, Salinas Valley study area. Southeast San Joaquin Valley study unit: KING, Kings study area; KWH, Kaweah study area; TLR, Tulare Lake study area; TULE, Tule study area. Benchmark type: HAL-US, U.S. Environmental Protection Agency lifetime health advisory level; NL-CA, CDPH notification level; MCL-CA, CDPH maximum contaminant level. Benchmark type and benchmark level as of April 1, 2010. Other abbreviations: USGS, U.S. Geological Survey; CDPH, California Department of Public Health; $\mu \mathrm{g} / \mathrm{L}$, micrograms per liter; LRL, laboratory reporting level; MRL, minimum reporting level; *, value greater than benchmark level; — not detected; <, less than; nc, not collected]

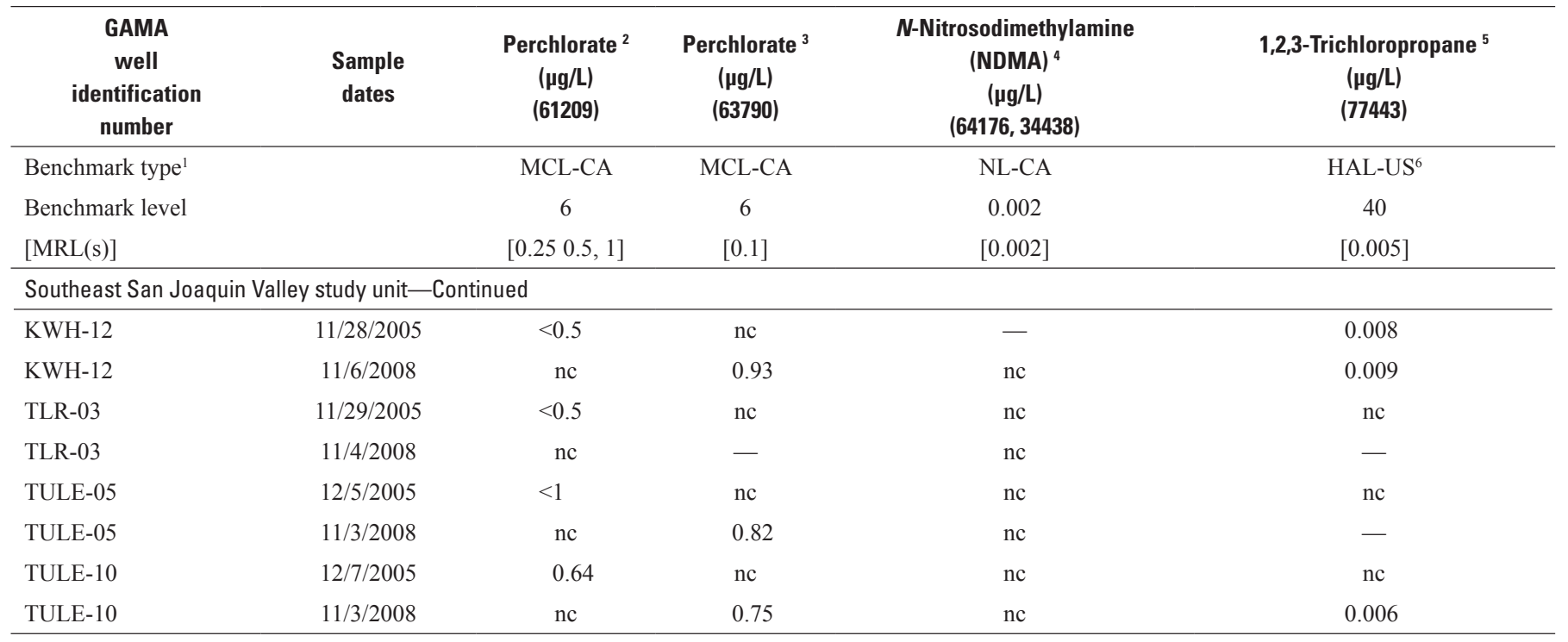

${ }^{1}$ Maximum contaminant level benchmarks are listed as MCL-US when the MCL-US and the MCL-CA are identical and as MCL-CA when the MCL-CA is lower than the MCL-US or no MCL-US exists.

${ }^{2}$ Prior to October 1, 2007, perchlorate analyses were performed on unfiltered samples by Mongomery Watson Harza (MWH) Laboratories (table A1). The nominal MRLs were 0.25 or $0.5 \mu \mathrm{g} / \mathrm{L}$; some higher salinity samples were diluted for analysis and had an MRL of $1 \mu \mathrm{g} / \mathrm{L}$.

${ }^{3}$ After August 15, 2007, perchlorate analyses were performed on filtered samples by Weck Laboratories, Inc. (table A1).

${ }^{4}$ NDMA analyses performed prior to October 1, 2007, by MWH were reported using parameter code 64176 and expressed in nanograms per liter, converted to micrograms per liter here. NDMA analyses performed after October 1, 2007, by Weck were reported using paramenter code 34438.

${ }_{5}^{5}$ 1,2,3-Trichloropropane (1,2,3-TCP) analyses were performed by MWH prior to October 1, 2007, and by Weck after that date. All samples were additionally analyzed for 1,2,3-TCP by the USGS NWQL Schedule 2020 with no detections by that analytical method, which had an LRL ranging from 0.12 to $0.18 \mu \mathrm{g} / \mathrm{L}$.

${ }^{6} \mathrm{In}$ some earlier reports in this series, the NL-CA $(0.005 \mu \mathrm{g} / \mathrm{L})$ was used as the comparison benchmark for 1,2,3-TCP. 
Table 8. Nutrients in samples collected from trend wells for seven Groundwater Ambient Monitoring and Assessment (GAMA) study units.

[The five-digit USGS parameter code below the constituent name is used to uniquely identify a specific constituent or property. Nutrients were analyzed in samples from 19 trend wells during 2004-05 and 50 trend wells in 2007-08; 18 wells were analyzed during both periods. Information about analytes given in table 3E. GAMA well identification number acronyms: San Diego Drainages study unit: SDALLV, Alluvial Basins study area; SDHDRK, Hard Rock study area; SDTEM, Temecula Valley study area; SDTEMFP, Temecula Valley study area flow path well; SDWARN, Warner Valley study area. North San Francisco Bay study unit: NSFVOL, Volcanic Highlands study area; NSFVP, Valley and Plains study area; NSFWG, Wilson Grove Formation Highlands study area; NSFWGFP, Wilson Grove Formation Highlands study area flow-path well. Northern San Joaquin Basin study unit: COS, Cosumnes Basin study area; ESJ, Eastern San Joaquin Basin study area; NSJ-QPC, Uplands study area; TRCY, Tracy Basin study area. Southern Sacramento Valley study unit: NAM, North American study area; SAM, South American study area; SOL, Solano study area; SSV-QPC, Uplands study area; SUI, Suisun-Fairfield study area; YOL, Yolo study area. San Fernando-San Gabriel study unit: ULASF, San Fernando study area; ULASG, San Gabriel study area. Monterey Bay and Salinas Valley Basins study unit: MSMB, Monterey Bay study area; MSPR, Paso Robles study area; MSSC, Santa Cruz study area; MSSV, Salinas Valley study area. Southeast San Joaquin Valley study unit: KING, Kings study area; KWH, Kaweah study area; TLR, Tulare Lake study area; TULE, Tule study area. Benchmark type: HAL-US, USEPA lifetime health advisory level; MCL-US, USEPA maximum contaminant level; MCL-CA, CDPH maximum contaminant level; CDPH, California Department of Public Health. Benchmark type, benchmark level, and RL as of April 1, 2010. Other abbreviations: USGS, U.S. Geological Survey; USEPA, U.S. Environmental Protection Agency; mg/L, milligrams per liter; LRL, laboratory reporting level; E, estimated or having a higher degree of uncertainty; nc, not collected; na, not available; *, value greater than benchmark level; —, not detected]

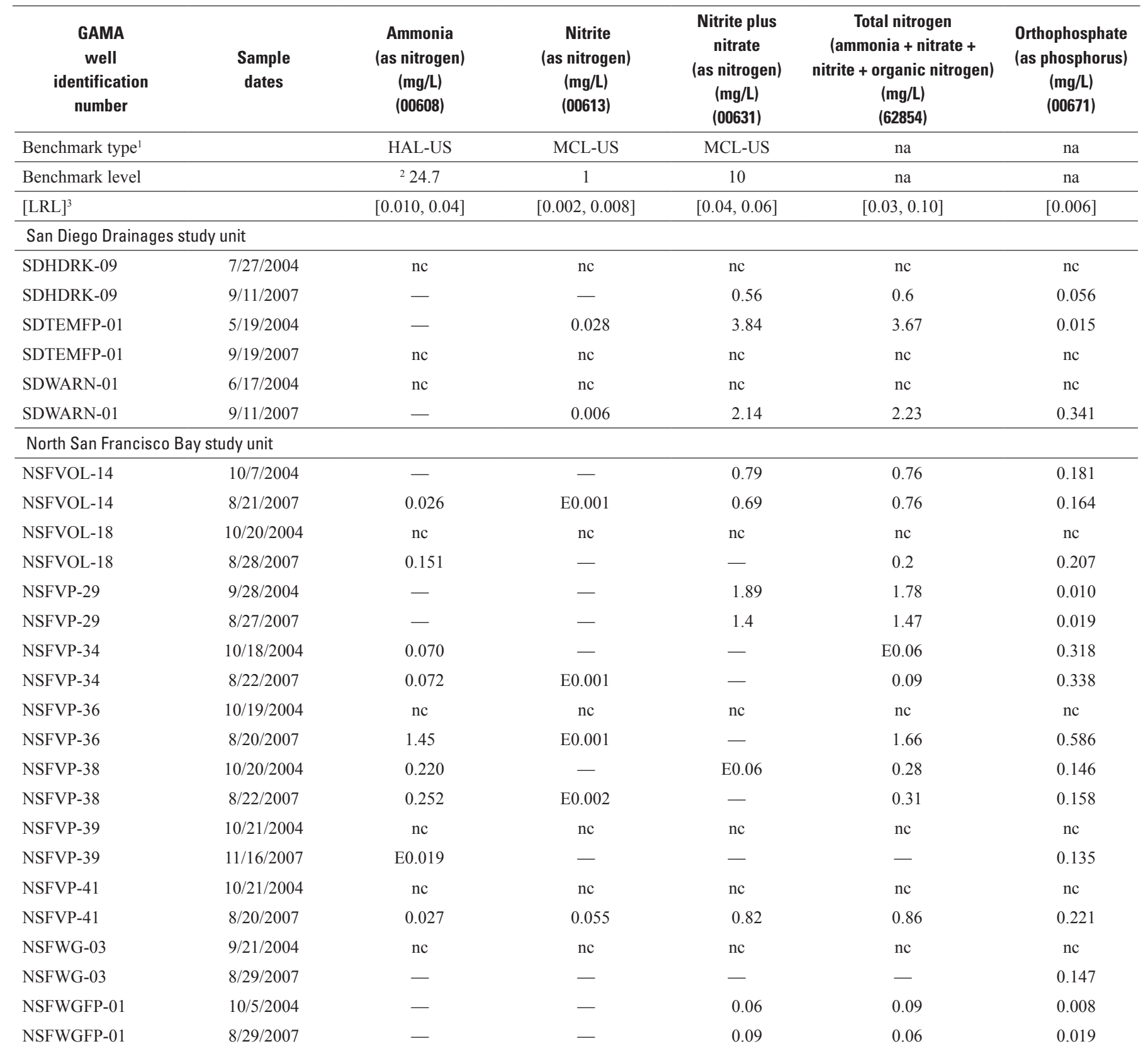


Table 8. Nutrients in samples collected from trend wells for seven Groundwater Ambient Monitoring and Assessment (GAMA) study units.-Continued

[The five-digit USGS parameter code below the constituent name is used to uniquely identify a specific constituent or property. Nutrients were analyzed in samples from 19 trend wells during 2004-05 and 50 trend wells in 2007-08; 18 wells were analyzed during both periods. Information about analytes given in table 3E. GAMA well identification number acronyms: San Diego Drainages study unit: SDALLV, Alluvial Basins study area; SDHDRK, Hard Rock study area; SDTEM, Temecula Valley study area; SDTEMFP, Temecula Valley study area flow path well; SDWARN, Warner Valley study area. North San Francisco Bay study unit: NSFVOL, Volcanic Highlands study area; NSFVP, Valley and Plains study area; NSFWG, Wilson Grove Formation Highlands study area; NSFWGFP, Wilson Grove Formation Highlands study area flow-path well. Northern San Joaquin Basin study unit: COS, Cosumnes Basin study area; ESJ, Eastern San Joaquin Basin study area; NSJ-QPC, Uplands study area; TRCY, Tracy Basin study area. Southern Sacramento Valley study unit: NAM, North American study area; SAM, South American study area; SOL, Solano study area; SSV-QPC, Uplands study area; SUI, Suisun-Fairfield study area; YOL, Yolo study area. San Fernando-San Gabriel study unit: ULASF, San Fernando study area; ULASG, San Gabriel study area. Monterey Bay and Salinas Valley Basins study unit: MSMB, Monterey Bay study area; MSPR, Paso Robles study area; MSSC, Santa Cruz study area; MSSV, Salinas Valley study area. Southeast San Joaquin Valley study unit: KING, Kings study area; KWH, Kaweah study area; TLR, Tulare Lake study area; TULE, Tule study area. Benchmark type: HAL-US, USEPA lifetime health advisory level; MCL-US, USEPA maximum contaminant level; MCL-CA, CDPH maximum contaminant level; CDPH, California Department of Public Health. Benchmark type, benchmark level, and RL as of April 1, 2010. Other abbreviations: USGS, U.S. Geological Survey; USEPA, U.S. Environmental Protection Agency; mg/L, milligrams per liter; LRL, laboratory reporting level; E, estimated or having a higher degree of uncertainty; nc, not collected; na, not available; *, value greater than benchmark level; - , not detected]

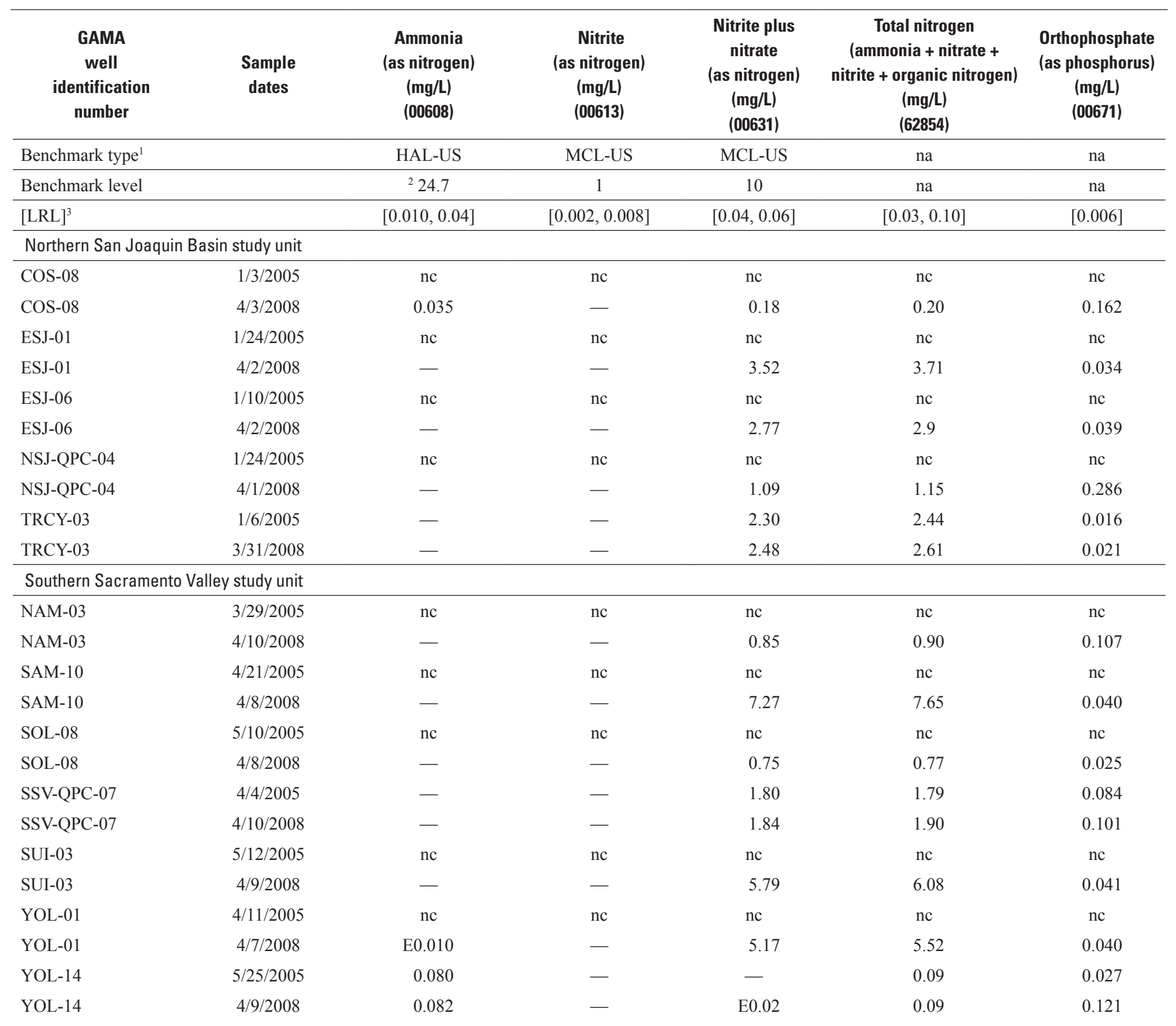


Table 8. Nutrients in samples collected from trend wells for seven Groundwater Ambient Monitoring and Assessment (GAMA) study units.-Continued

[The five-digit USGS parameter code below the constituent name is used to uniquely identify a specific constituent or property. Nutrients were analyzed in samples from 19 trend wells during 2004-05 and 50 trend wells in 2007-08; 18 wells were analyzed during both periods. Information about analytes given in table 3E. GAMA well identification number acronyms: San Diego Drainages study unit: SDALLV, Alluvial Basins study area; SDHDRK, Hard Rock study area; SDTEM, Temecula Valley study area; SDTEMFP, Temecula Valley study area flow path well; SDWARN, Warner Valley study area. North San Francisco Bay study unit: NSFVOL, Volcanic Highlands study area; NSFVP, Valley and Plains study area; NSFWG, Wilson Grove Formation Highlands study area; NSFWGFP, Wilson Grove Formation Highlands study area flow-path well. Northern San Joaquin Basin study unit: COS, Cosumnes Basin study area; ESJ, Eastern San Joaquin Basin study area; NSJ-QPC, Uplands study area; TRCY, Tracy Basin study area. Southern Sacramento Valley study unit: NAM, North American study area; SAM, South American study area; SOL, Solano study area; SSV-QPC, Uplands study area; SUI, Suisun-Fairfield study area; YOL, Yolo study area. San Fernando-San Gabriel study unit: ULASF, San Fernando study area; ULASG, San Gabriel study area. Monterey Bay and Salinas Valley Basins study unit: MSMB, Monterey Bay study area; MSPR, Paso Robles study area; MSSC, Santa Cruz study area; MSSV, Salinas Valley study area. Southeast San Joaquin Valley study unit: KING, Kings study area; KWH, Kaweah study area; TLR, Tulare Lake study area; TULE, Tule study area. Benchmark type: HAL-US, USEPA lifetime health advisory level; MCL-US, USEPA maximum contaminant level; MCL-CA, CDPH maximum contaminant level; CDPH, California Department of Public Health. Benchmark type, benchmark level, and RL as of April 1, 2010. Other abbreviations: USGS, U.S. Geological Survey; USEPA, U.S. Environmental Protection Agency; mg/L, milligrams per liter; LRL, laboratory reporting level; E, estimated or having a higher degree of uncertainty; nc, not collected; na, not available; *, value greater than benchmark level; —, not detected]

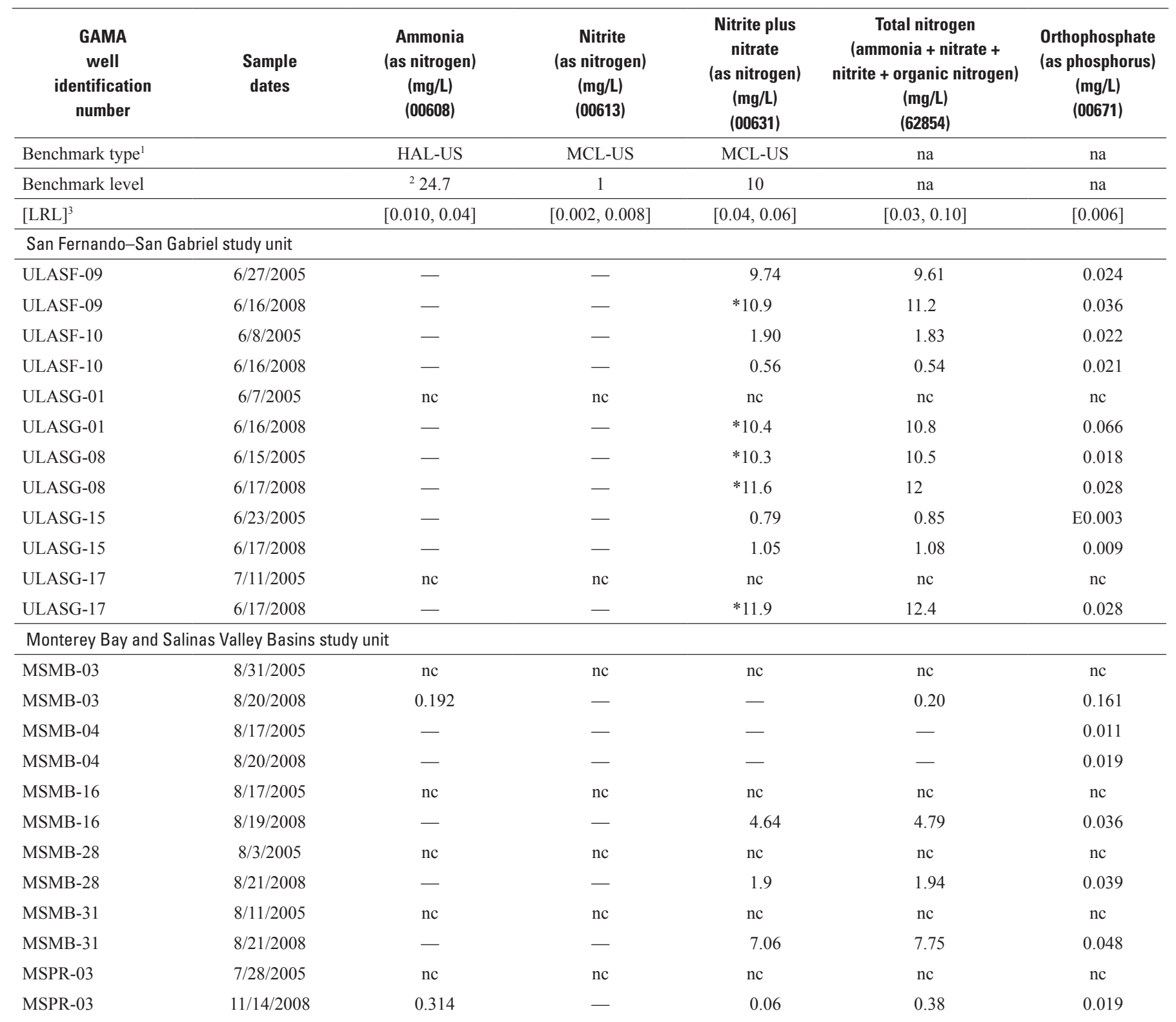


Table 8. Nutrients in samples collected from trend wells for seven Groundwater Ambient Monitoring and Assessment (GAMA) study units.-Continued

[The five-digit USGS parameter code below the constituent name is used to uniquely identify a specific constituent or property. Nutrients were analyzed in samples from 19 trend wells during 2004-05 and 50 trend wells in 2007-08; 18 wells were analyzed during both periods. Information about analytes given in table 3E. GAMA well identification number acronyms: San Diego Drainages study unit: SDALLV, Alluvial Basins study area; SDHDRK, Hard Rock study area; SDTEM, Temecula Valley study area; SDTEMFP, Temecula Valley study area flow path well; SDWARN, Warner Valley study area. North San Francisco Bay study unit: NSFVOL, Volcanic Highlands study area; NSFVP, Valley and Plains study area; NSFWG, Wilson Grove Formation Highlands study area; NSFWGFP, Wilson Grove Formation Highlands study area flow-path well. Northern San Joaquin Basin study unit: COS, Cosumnes Basin study area; ESJ, Eastern San Joaquin Basin study area; NSJ-QPC, Uplands study area; TRCY, Tracy Basin study area. Southern Sacramento Valley study unit: NAM, North American study area; SAM, South American study area; SOL, Solano study area; SSV-QPC, Uplands study area; SUI, Suisun-Fairfield study area; YOL, Yolo study area. San Fernando-San Gabriel study unit: ULASF, San Fernando study area; ULASG, San Gabriel study area. Monterey Bay and Salinas Valley Basins study unit: MSMB, Monterey Bay study area; MSPR, Paso Robles study area; MSSC, Santa Cruz study area; MSSV, Salinas Valley study area. Southeast San Joaquin Valley study unit: KING, Kings study area; KWH, Kaweah study area; TLR, Tulare Lake study area; TULE, Tule study area. Benchmark type: HAL-US, USEPA lifetime health advisory level; MCL-US, USEPA maximum contaminant level; MCL-CA, CDPH maximum contaminant level; CDPH, California Department of Public Health. Benchmark type, benchmark level, and RL as of April 1, 2010. Other abbreviations: USGS, U.S. Geological Survey; USEPA, U.S. Environmental Protection Agency; mg/L, milligrams per liter; LRL, laboratory reporting level; E, estimated or having a higher degree of uncertainty; nc, not collected; na, not available; *, value greater than benchmark level; - , not detected]

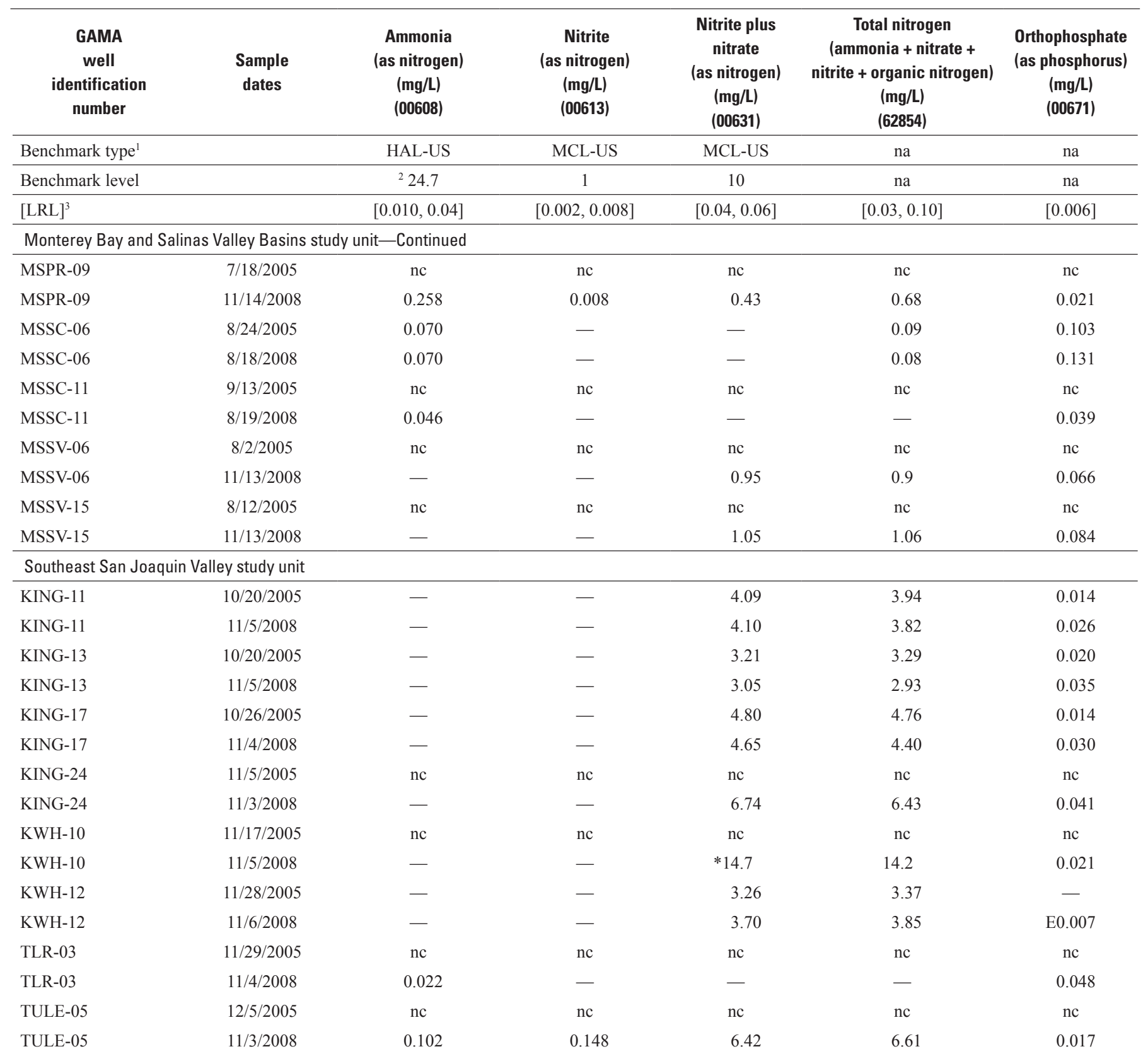


Table 8. Nutrients in samples collected from trend wells for seven Groundwater Ambient Monitoring and Assessment (GAMA) study units.-Continued

[The five-digit USGS parameter code below the constituent name is used to uniquely identify a specific constituent or property. Nutrients were analyzed in samples from 19 trend wells during 2004-05 and 50 trend wells in 2007-08; 18 wells were analyzed during both periods. Information about analytes given in table 3E. GAMA well identification number acronyms: San Diego Drainages study unit: SDALLV, Alluvial Basins study area; SDHDRK, Hard Rock study area; SDTEM, Temecula Valley study area; SDTEMFP, Temecula Valley study area flow path well; SDWARN, Warner Valley study area. North San Francisco Bay study unit: NSFVOL, Volcanic Highlands study area; NSFVP, Valley and Plains study area; NSFWG, Wilson Grove Formation Highlands study area; NSFWGFP, Wilson Grove Formation Highlands study area flow-path well. Northern San Joaquin Basin study unit: COS, Cosumnes Basin study area; ESJ, Eastern San Joaquin Basin study area; NSJ-QPC, Uplands study area; TRCY, Tracy Basin study area. Southern Sacramento Valley study unit: NAM, North American study area; SAM, South American study area; SOL, Solano study area; SSV-QPC, Uplands study area; SUI, Suisun-Fairfield study area; YOL, Yolo study area. San Fernando-San Gabriel study unit: ULASF, San Fernando study area; ULASG, San Gabriel study area. Monterey Bay and Salinas Valley Basins study unit: MSMB, Monterey Bay study area; MSPR, Paso Robles study area; MSSC, Santa Cruz study area; MSSV, Salinas Valley study area. Southeast San Joaquin Valley study unit: KING, Kings study area; KWH, Kaweah study area; TLR, Tulare Lake study area; TULE, Tule study area. Benchmark type: HAL-US, USEPA lifetime health advisory level; MCL-US, USEPA maximum contaminant level; MCL-CA, CDPH maximum contaminant level; CDPH, California Department of Public Health. Benchmark type, benchmark level, and RL as of April 1, 2010. Other abbreviations: USGS, U.S. Geological Survey; USEPA, U.S. Environmental Protection Agency; mg/L, milligrams per liter; LRL, laboratory reporting level; E, estimated or having a higher degree of uncertainty; nc, not collected; na, not available; *, value greater than benchmark level; —, not detected]

\begin{tabular}{|c|c|c|c|c|c|c|}
\hline $\begin{array}{c}\text { GAMA } \\
\text { well } \\
\text { identification } \\
\text { number }\end{array}$ & $\begin{array}{c}\text { Sample } \\
\text { dates }\end{array}$ & $\begin{array}{c}\text { Ammonia } \\
\text { (as nitrogen) } \\
\text { (mg/L) } \\
\text { (00608) }\end{array}$ & $\begin{array}{c}\text { Nitrite } \\
\text { (as nitrogen) } \\
\text { (mg/L) } \\
\text { (00613) }\end{array}$ & $\begin{array}{l}\text { Nitrite plus } \\
\text { nitrate } \\
\text { (as nitrogen) } \\
\text { (mg/L) } \\
\text { (00631) }\end{array}$ & $\begin{array}{c}\text { Total nitrogen } \\
\text { (ammonia + nitrate + } \\
\text { nitrite + organic nitrogen) } \\
\text { (mg/L) } \\
(62854)\end{array}$ & $\begin{array}{c}\text { Orthophosphate } \\
\text { (as phosphorus) } \\
\text { (mg/L) } \\
\text { (00671) }\end{array}$ \\
\hline Benchmark type $^{1}$ & & HAL-US & MCL-US & MCL-US & na & na \\
\hline Benchmark level & & ${ }^{2} 24.7$ & 1 & 10 & na & na \\
\hline TULE-10 & $12 / 7 / 2005$ & $\mathrm{nc}$ & $\mathrm{nc}$ & $\mathrm{nc}$ & $\mathrm{nc}$ & $\mathrm{nc}$ \\
\hline TULE-10 & $11 / 3 / 2008$ & - & - & 9.25 & 9.17 & 0.020 \\
\hline
\end{tabular}

${ }^{1}$ Maximum contaminant level benchmarks are listed as MCL-US when the MCL-US and MCL-CA are identical and as MCL-CA when the MCL-CA is lower than the MCL-US or no MCL-US exists.

${ }^{2}$ The HAL-US is $30 \mathrm{mg} / \mathrm{L}$ "as ammonia." To facilitate comparison to the analytical results, we have converted and reported this HAL-US as $24.7 \mathrm{mg} / \mathrm{L}$ "as nitrogen."

${ }^{3}$ Minimum and maximum LRL used during study period, or only LRL used during study period. 
Tables $\quad 119$

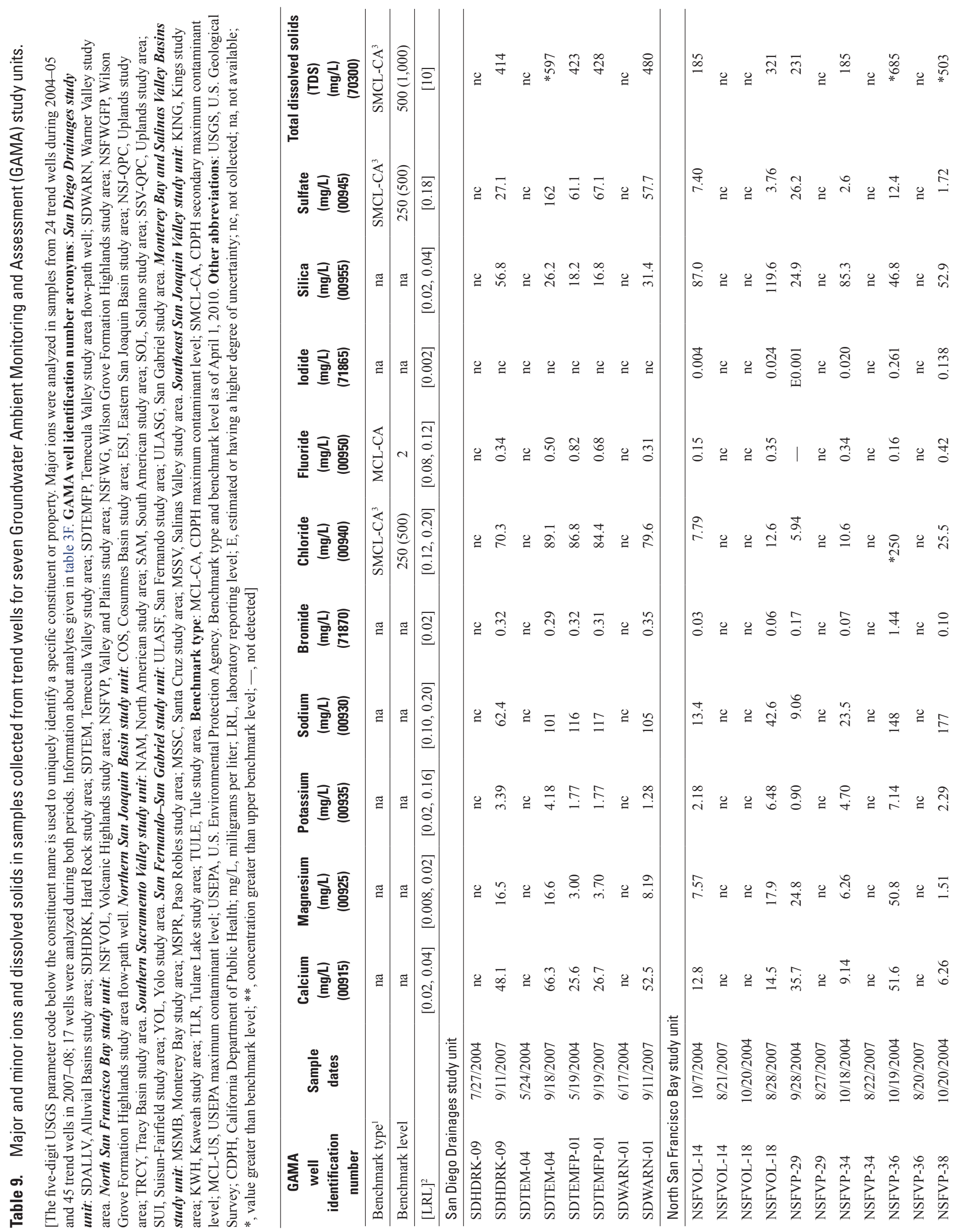




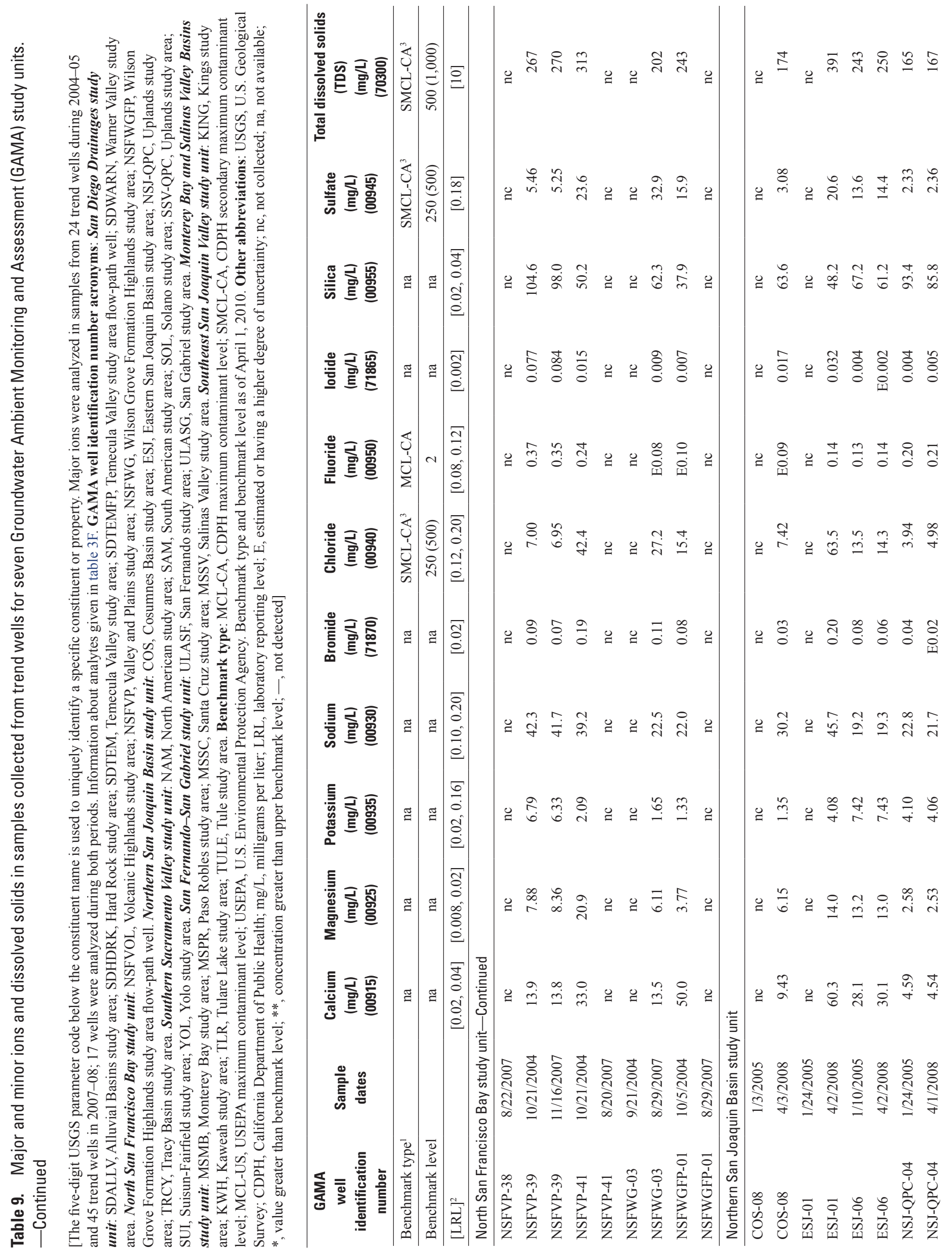


Tables 121

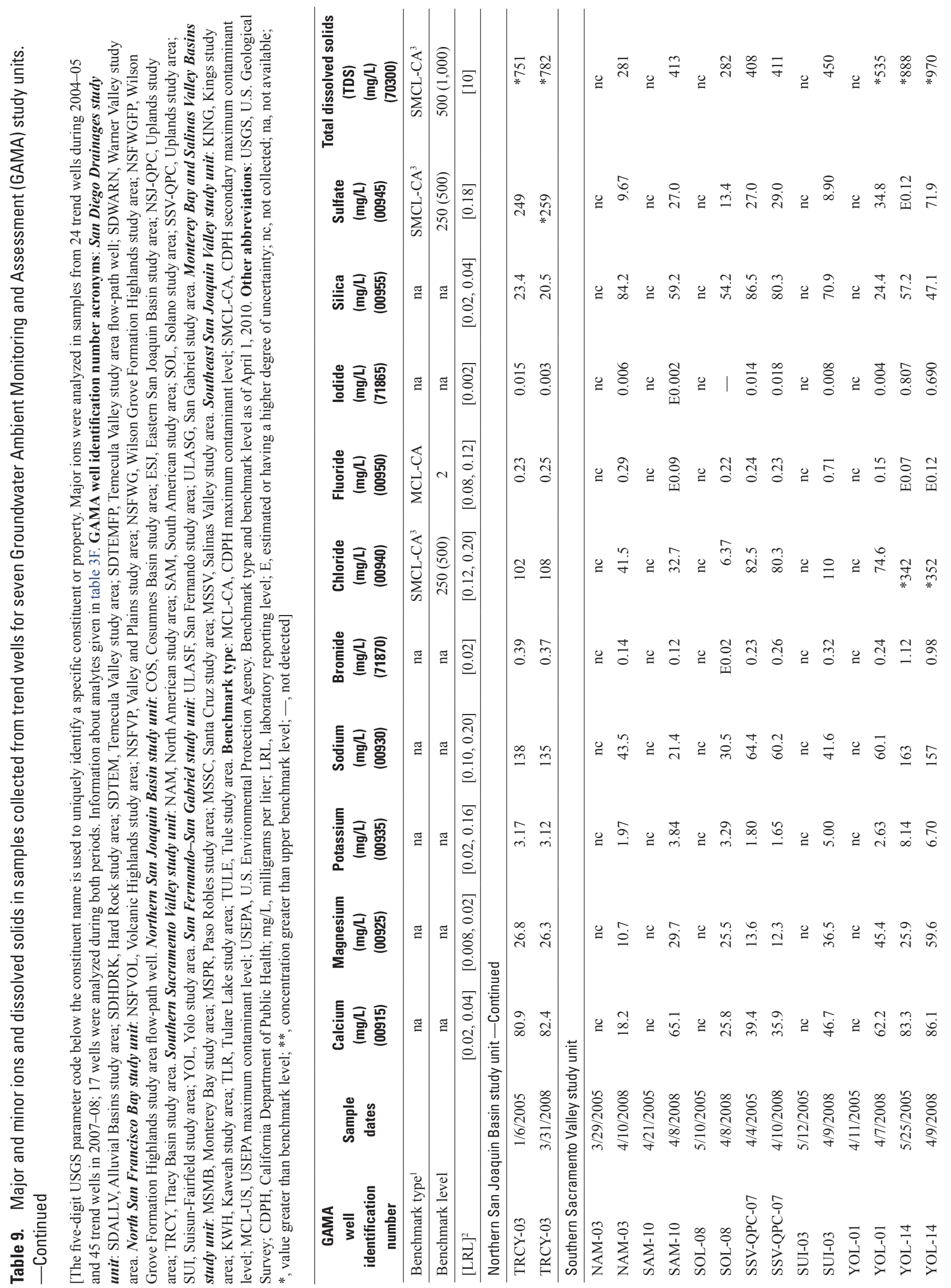




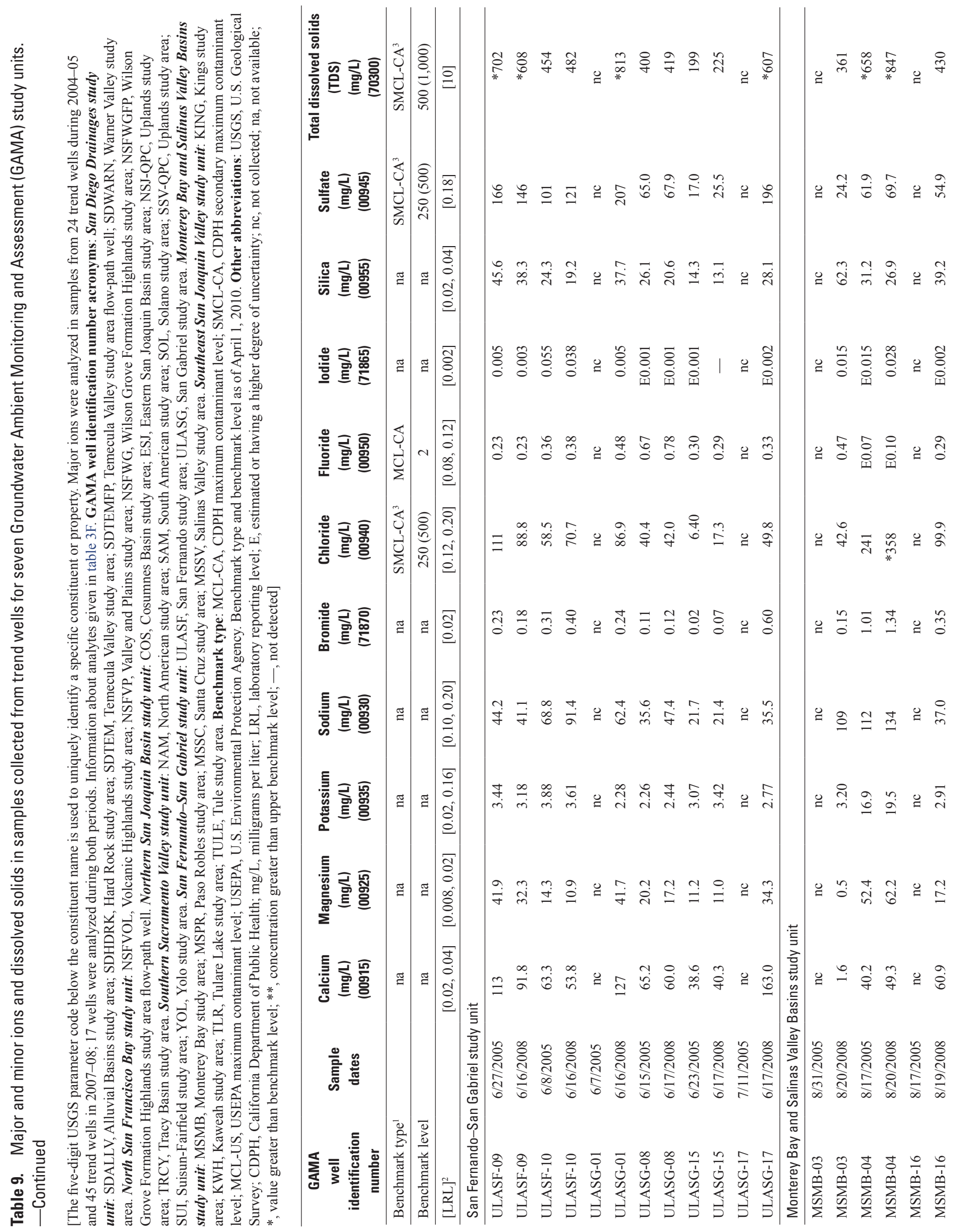


Tables 123

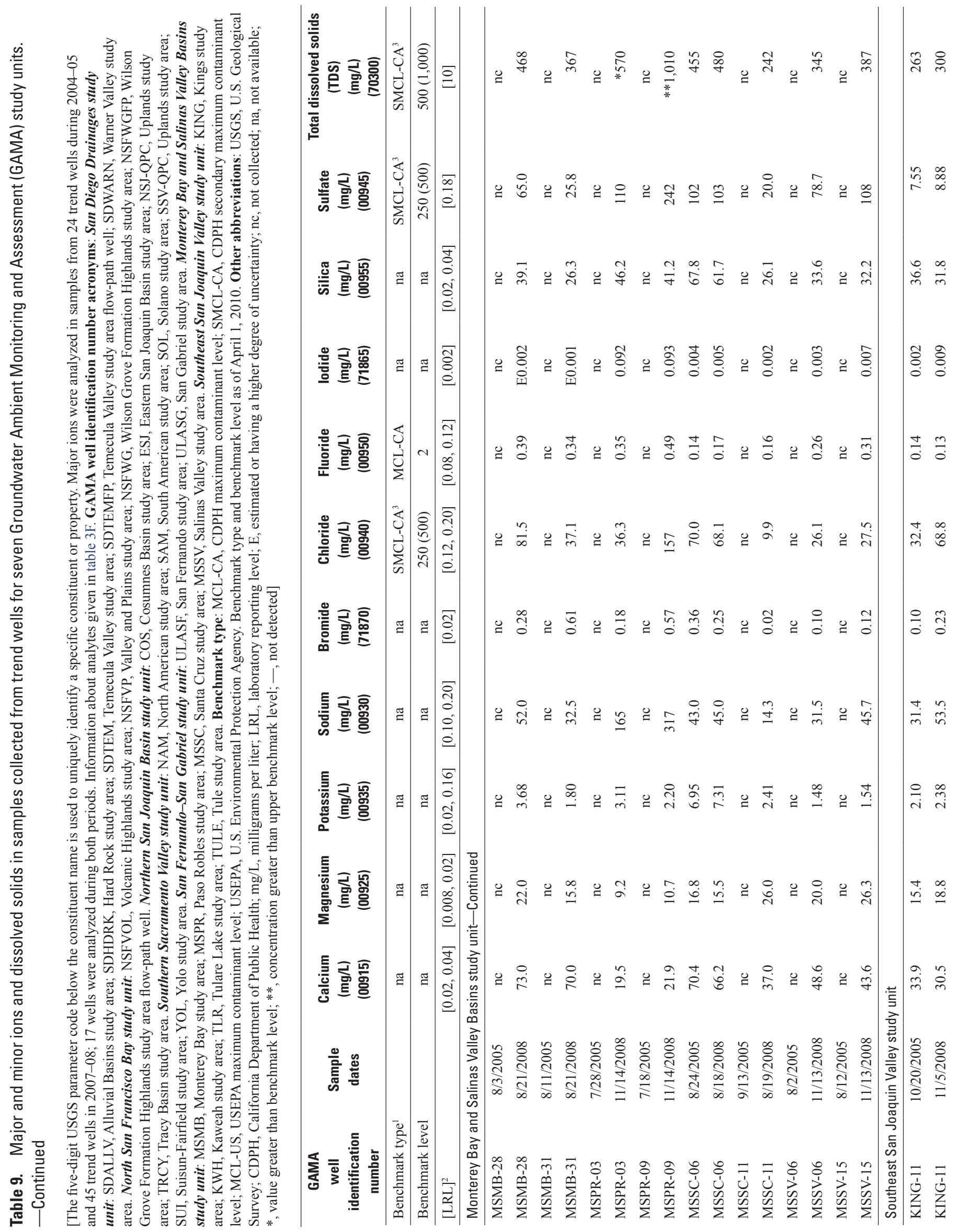




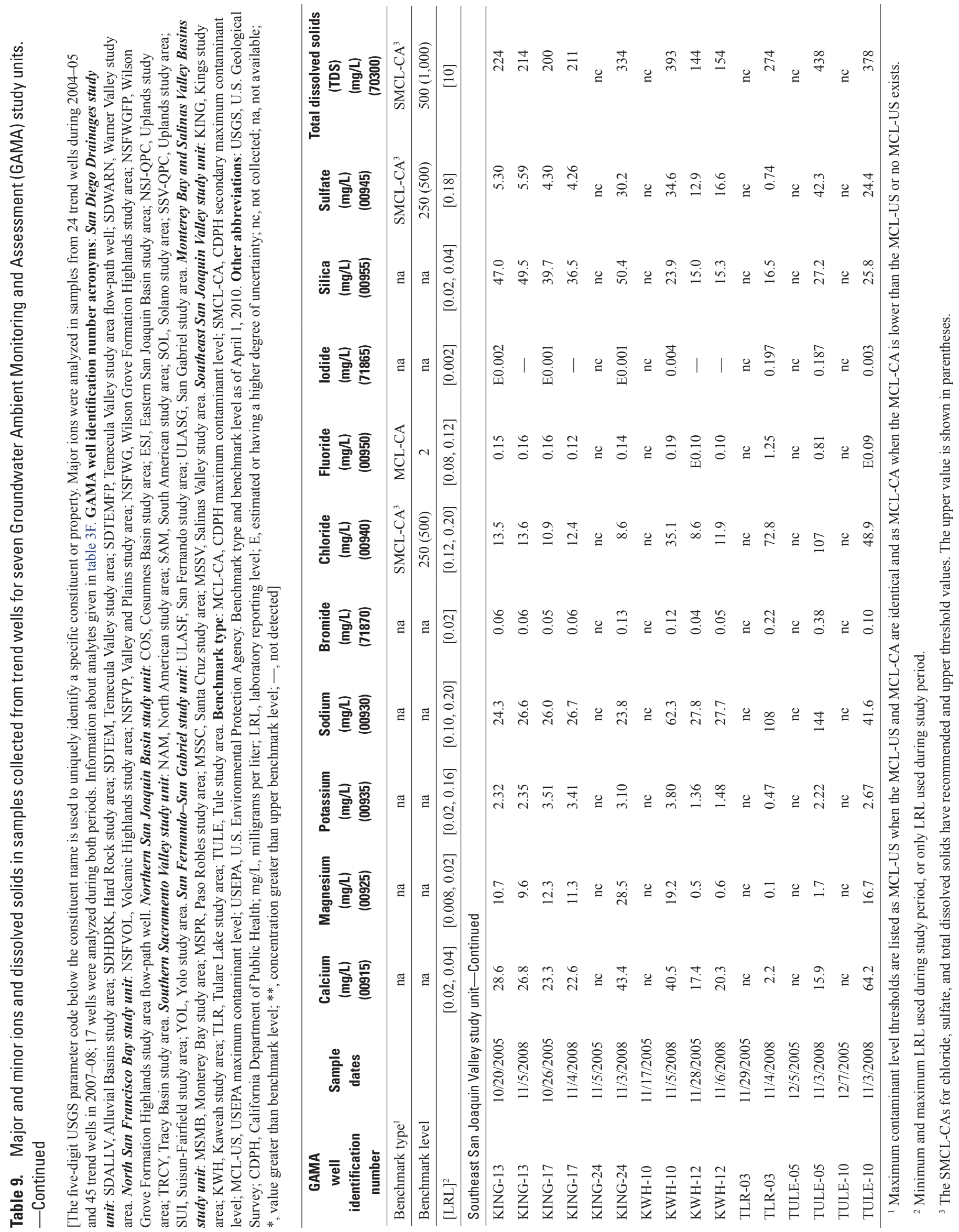


Tables 125

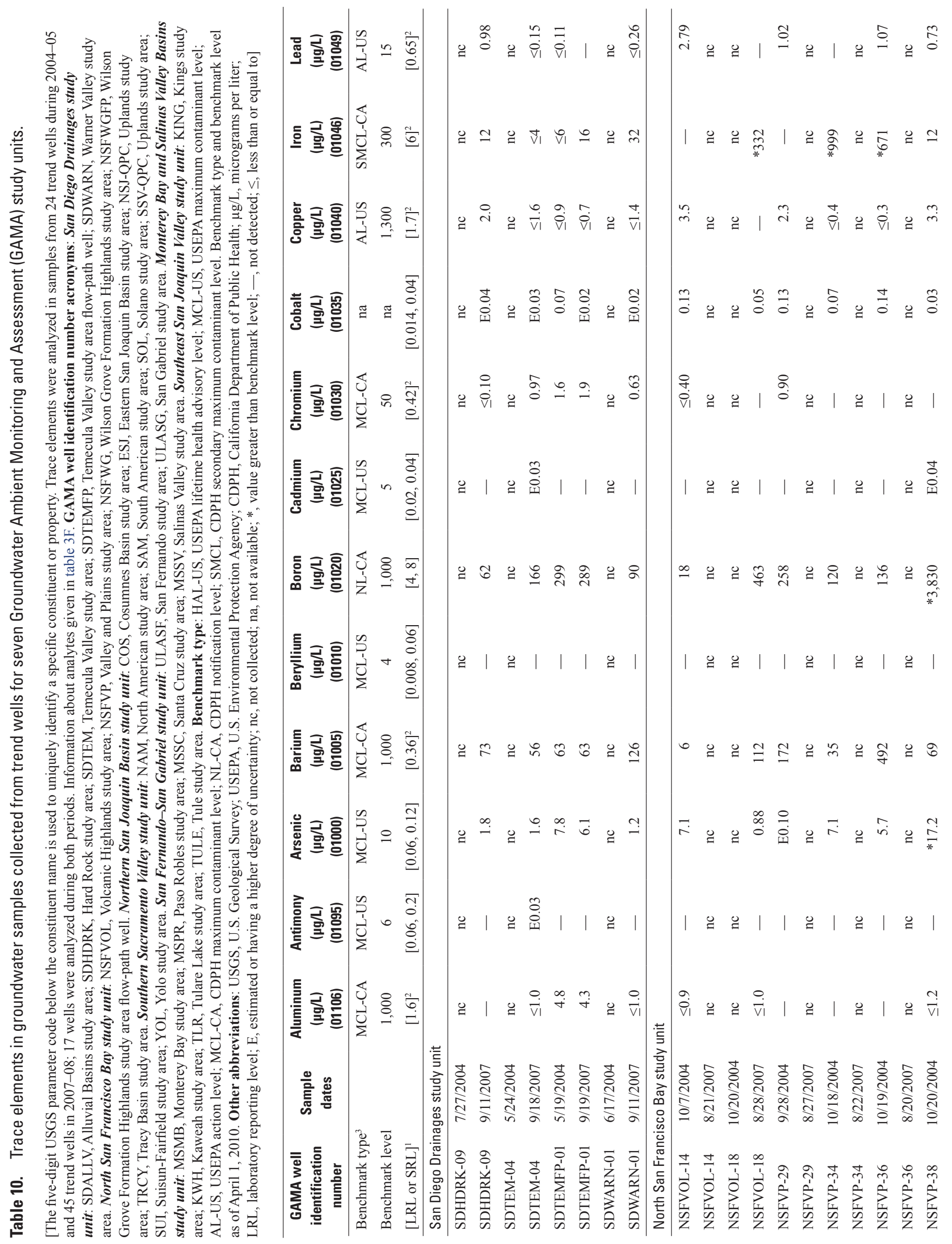



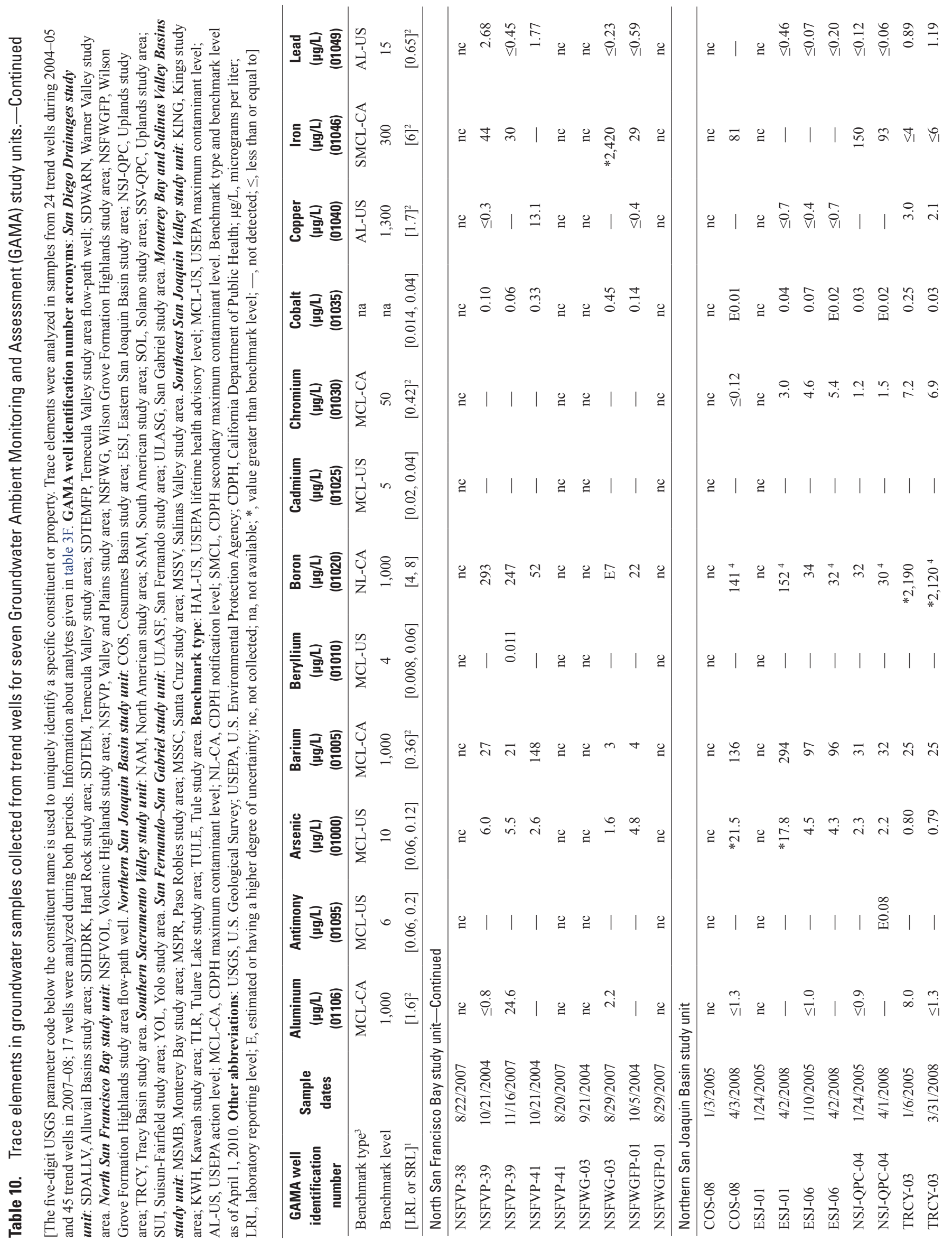
Tables 127

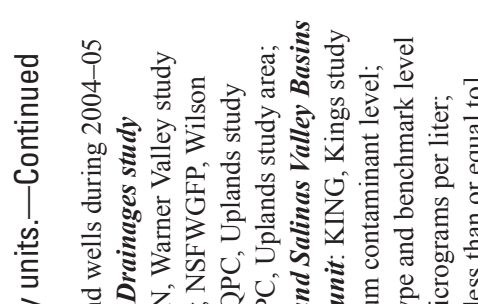

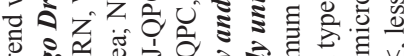

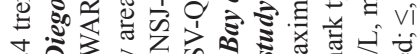

त 을 它的

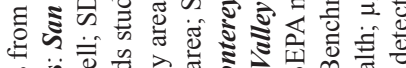

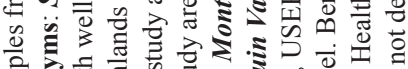

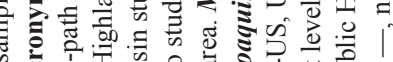

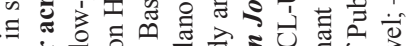

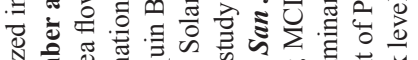

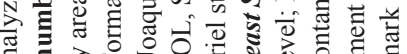

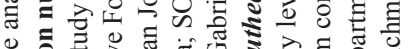

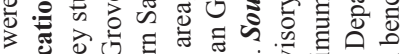

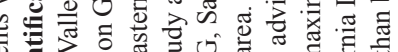

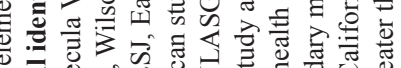

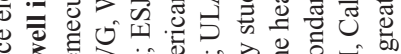

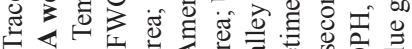

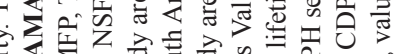

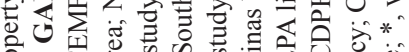

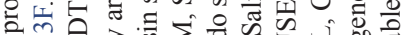

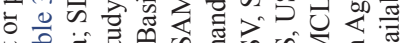

过 ơ

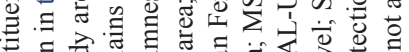

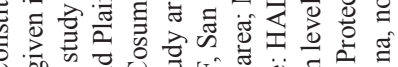

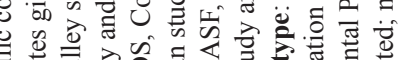

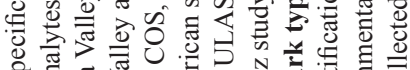

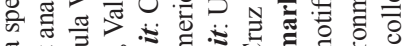

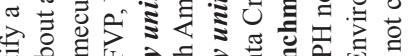

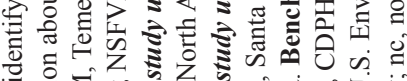

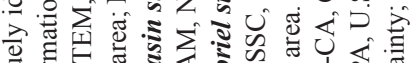

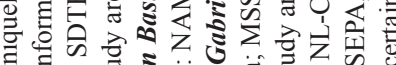

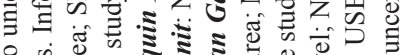

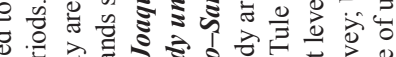

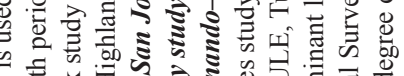

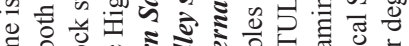

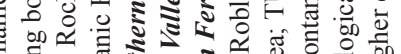

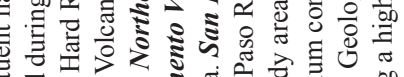

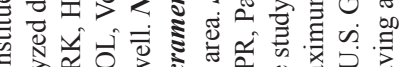

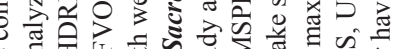

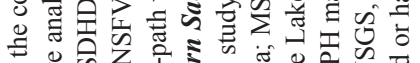

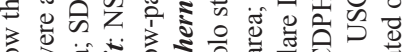

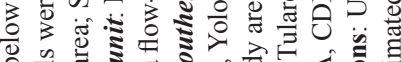

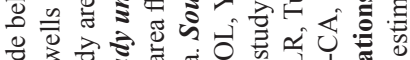

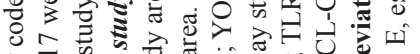

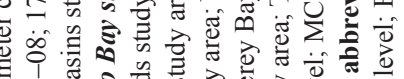

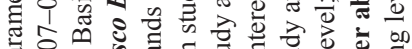

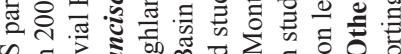
d

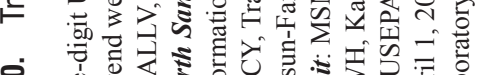

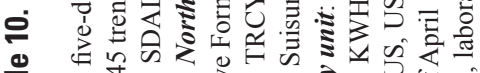

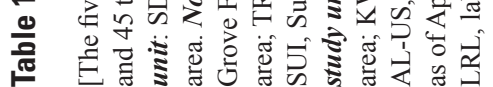

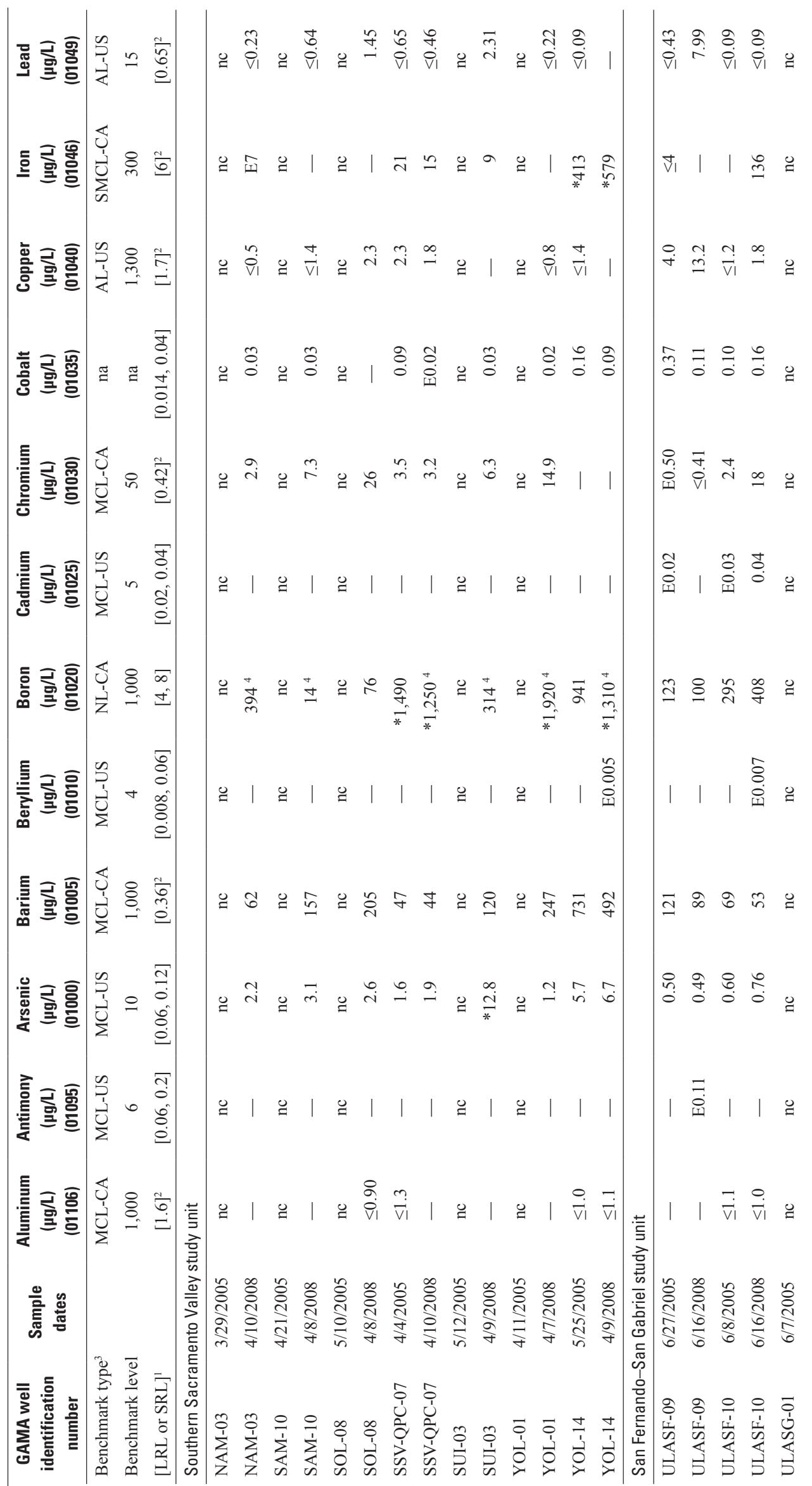



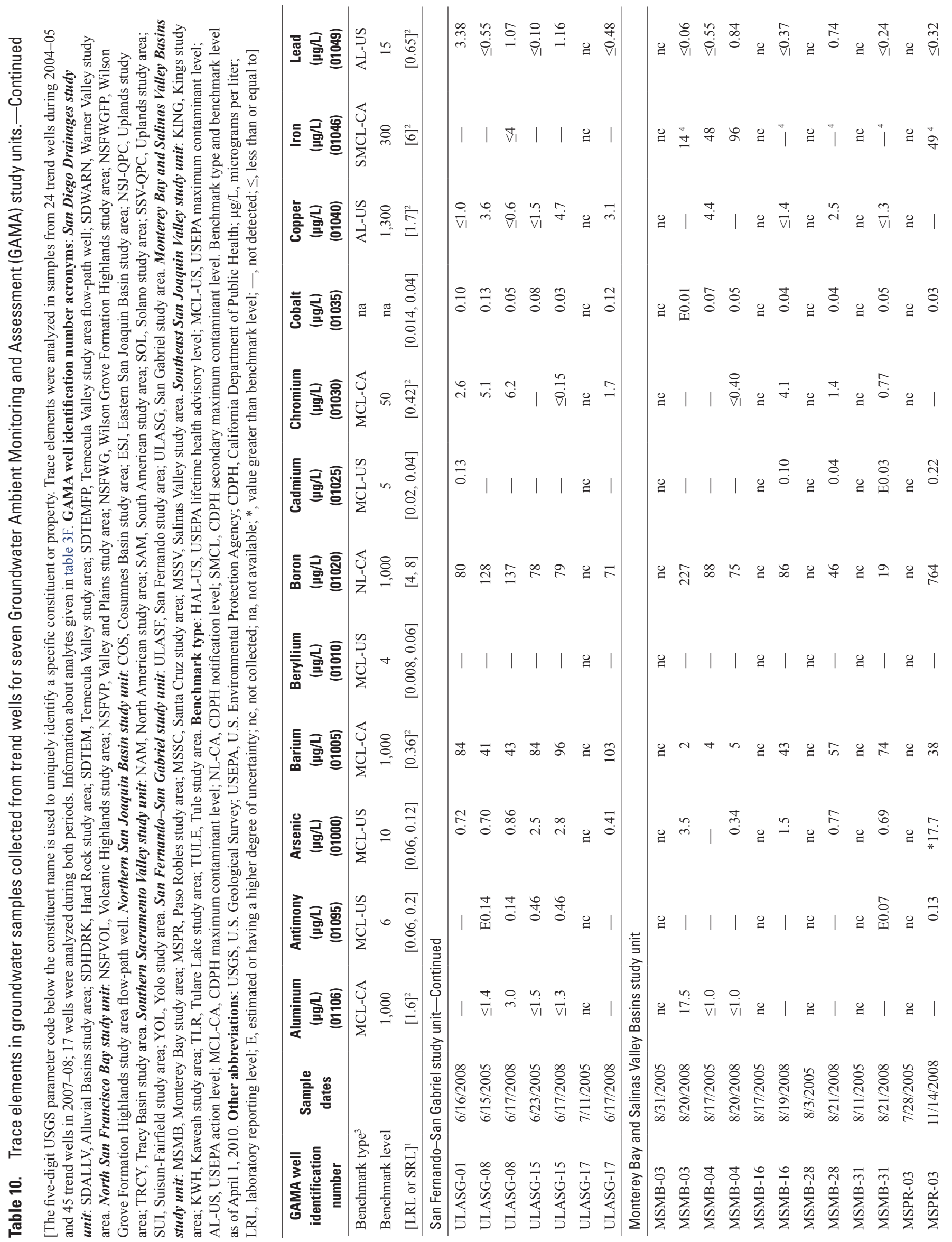
Tables $\quad 129$

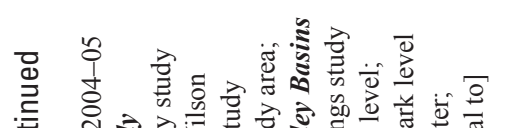

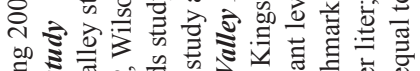

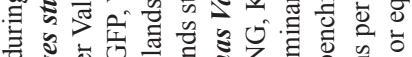

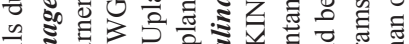
ब है ช

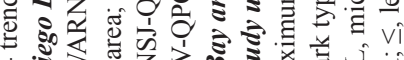

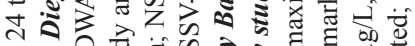

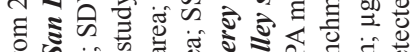

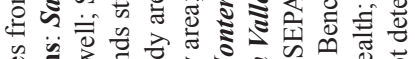

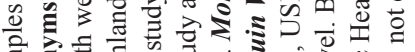

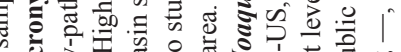

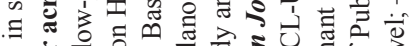

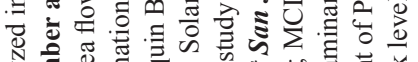

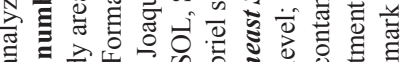

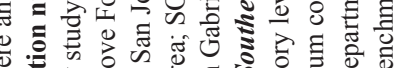

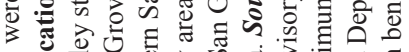

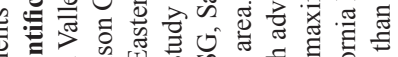

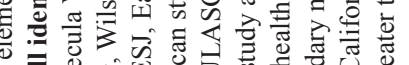

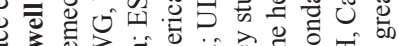

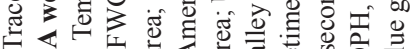

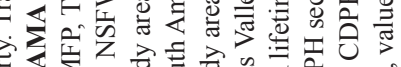

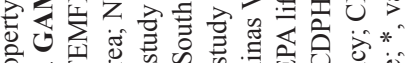

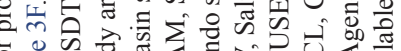

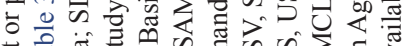

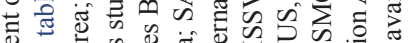

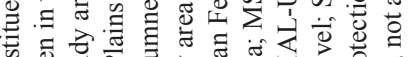

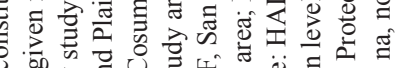

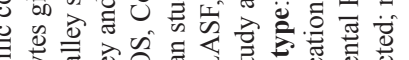

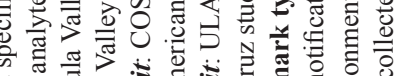

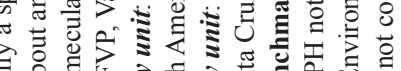

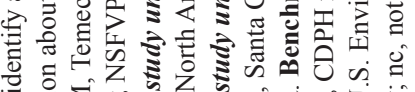

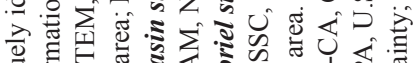

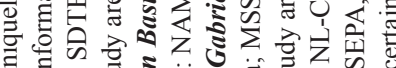

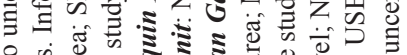

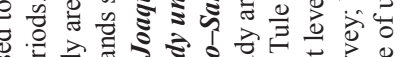

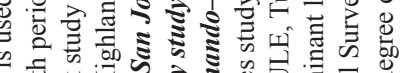
的

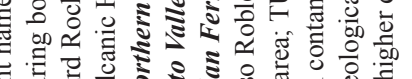

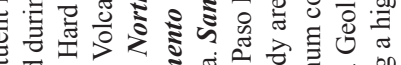

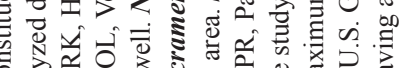

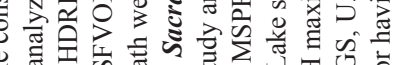

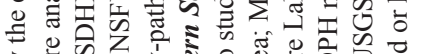

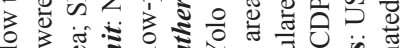

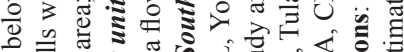

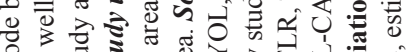

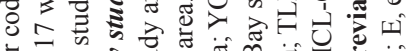

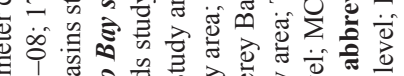

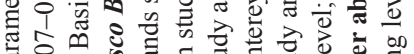

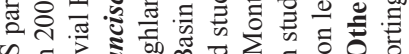
ब 要

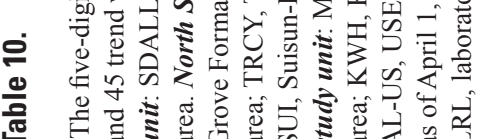

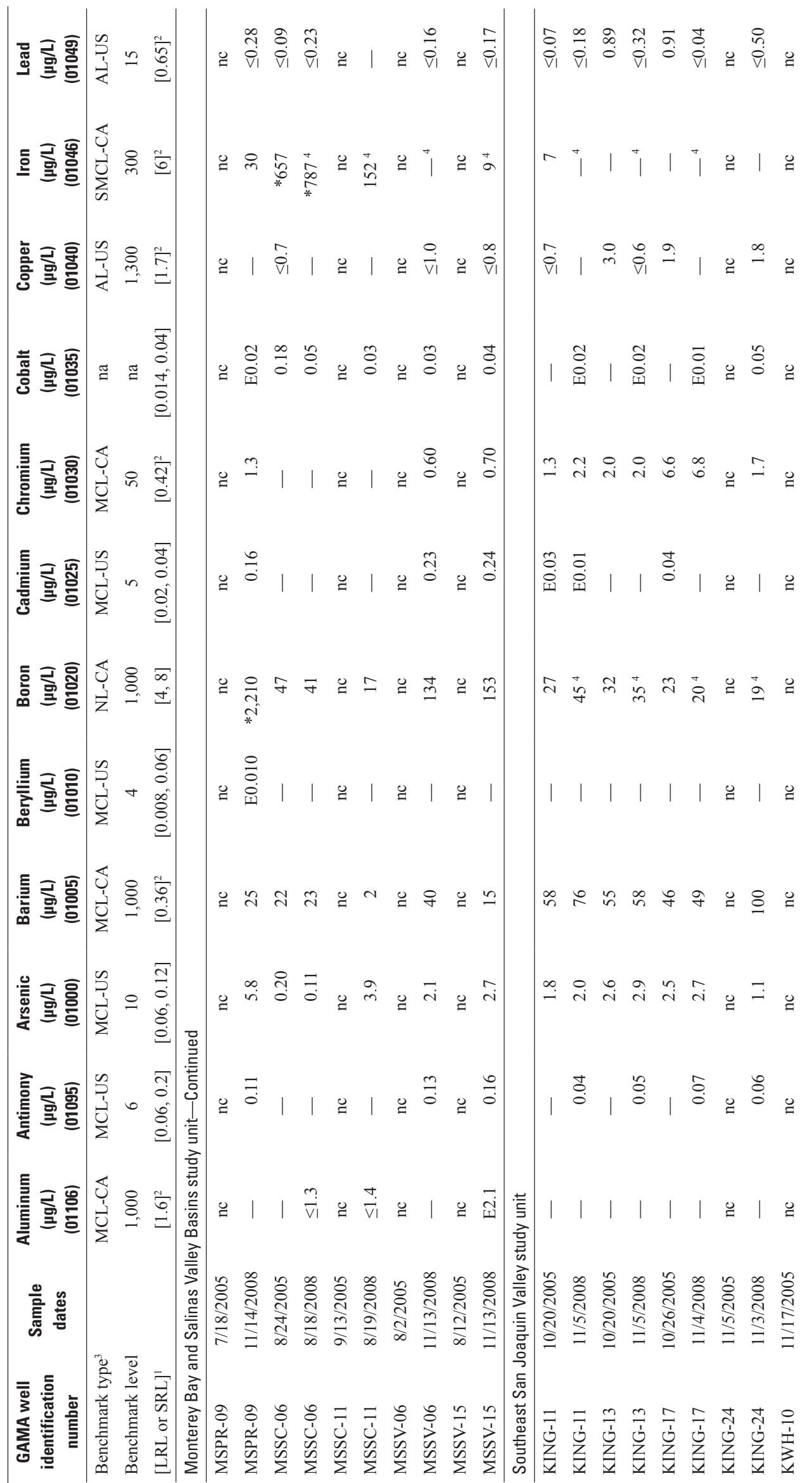




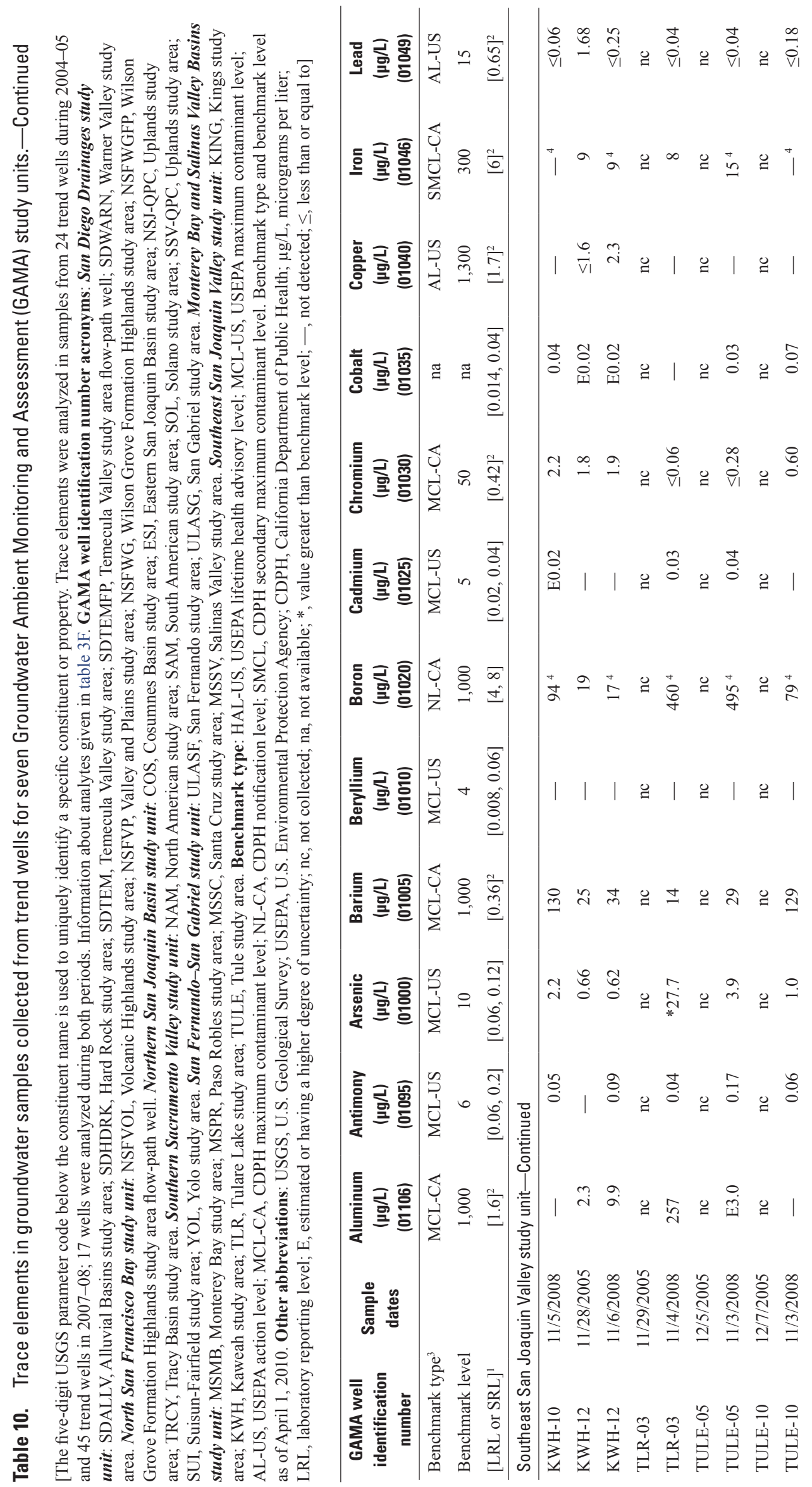




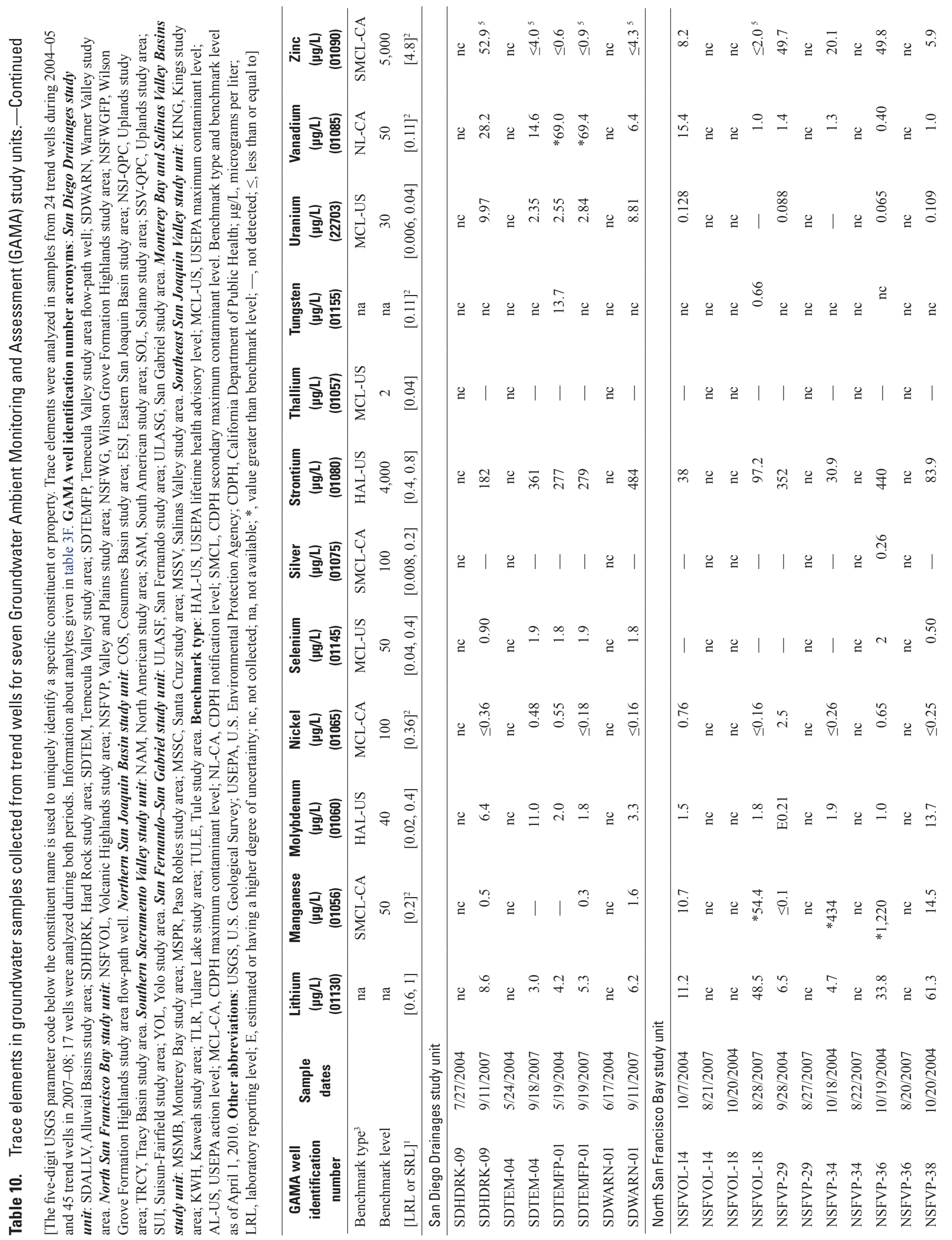




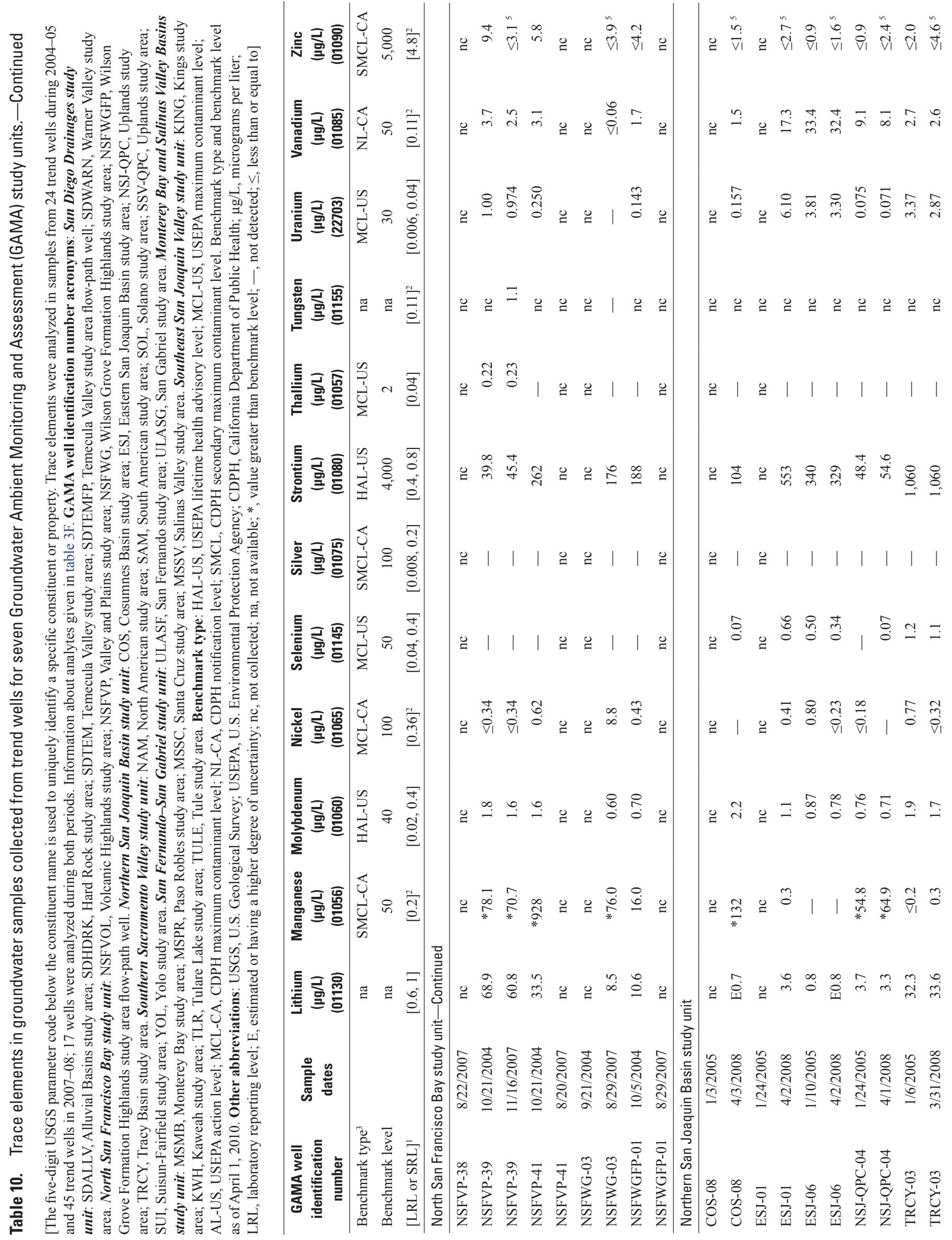


Tables 133

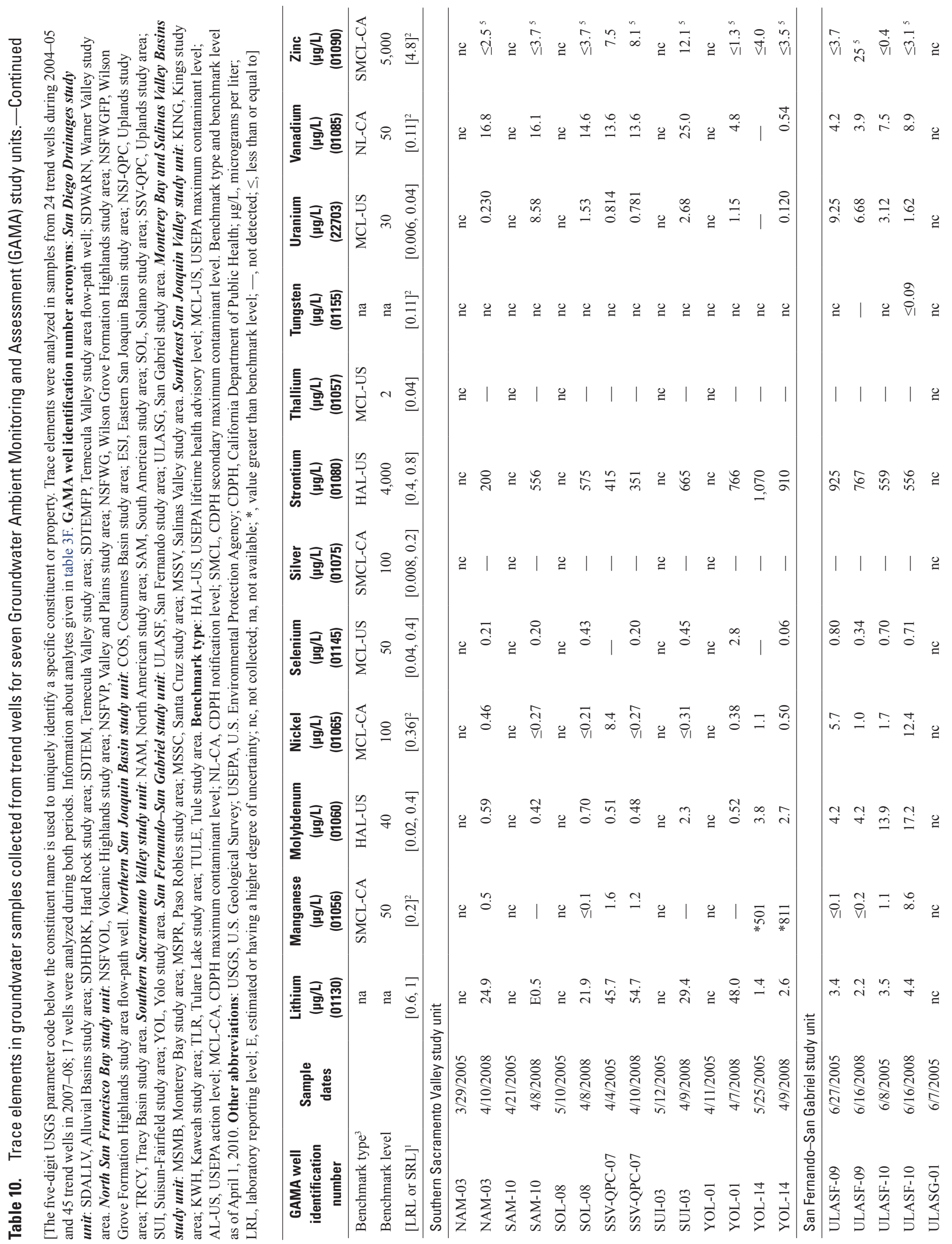




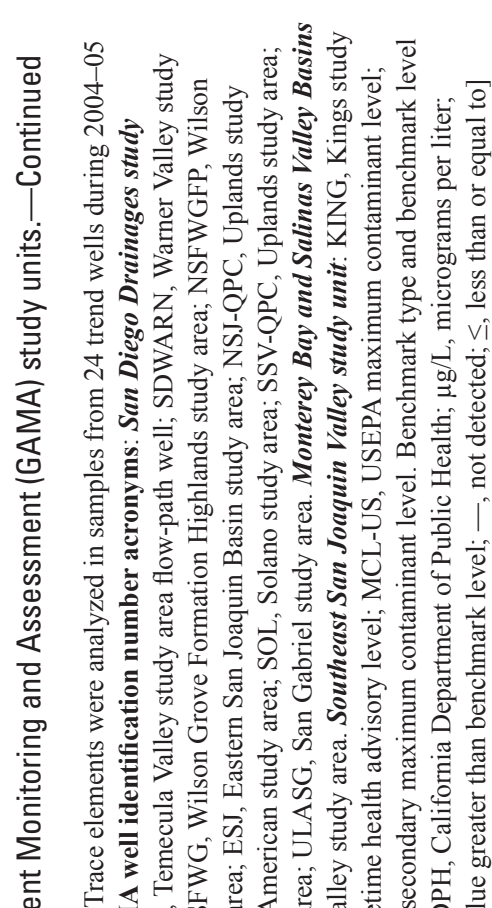

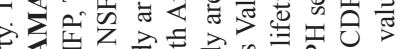

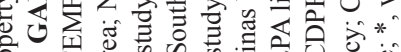

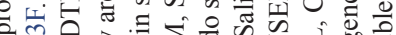

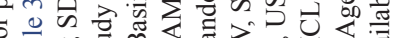

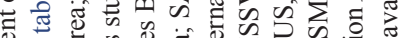

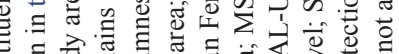

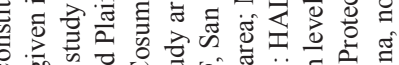

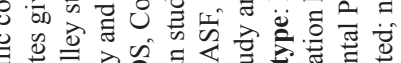

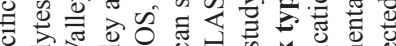

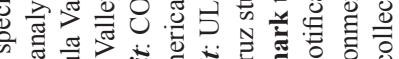

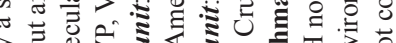

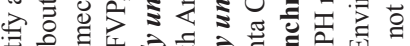

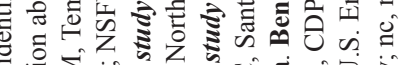

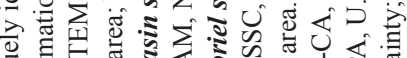

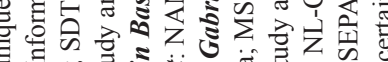

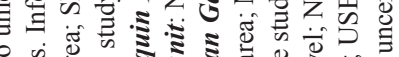

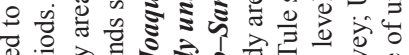

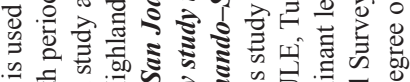

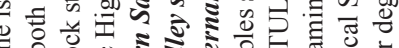

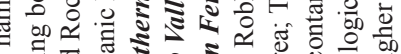

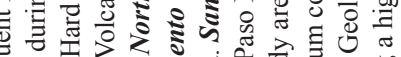

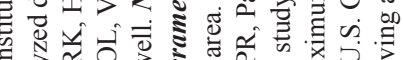

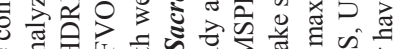

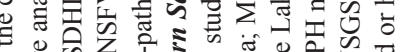
วक की 응

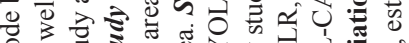

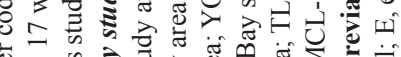

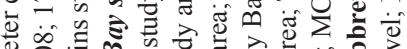

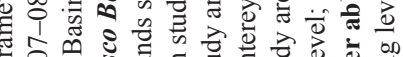

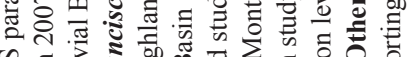
प.

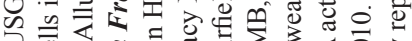

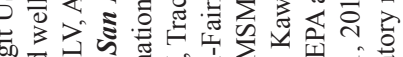

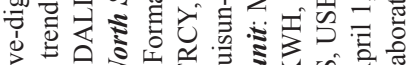

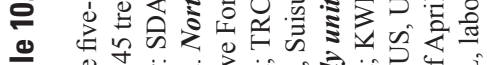

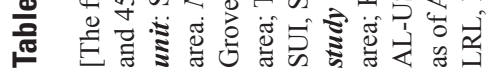

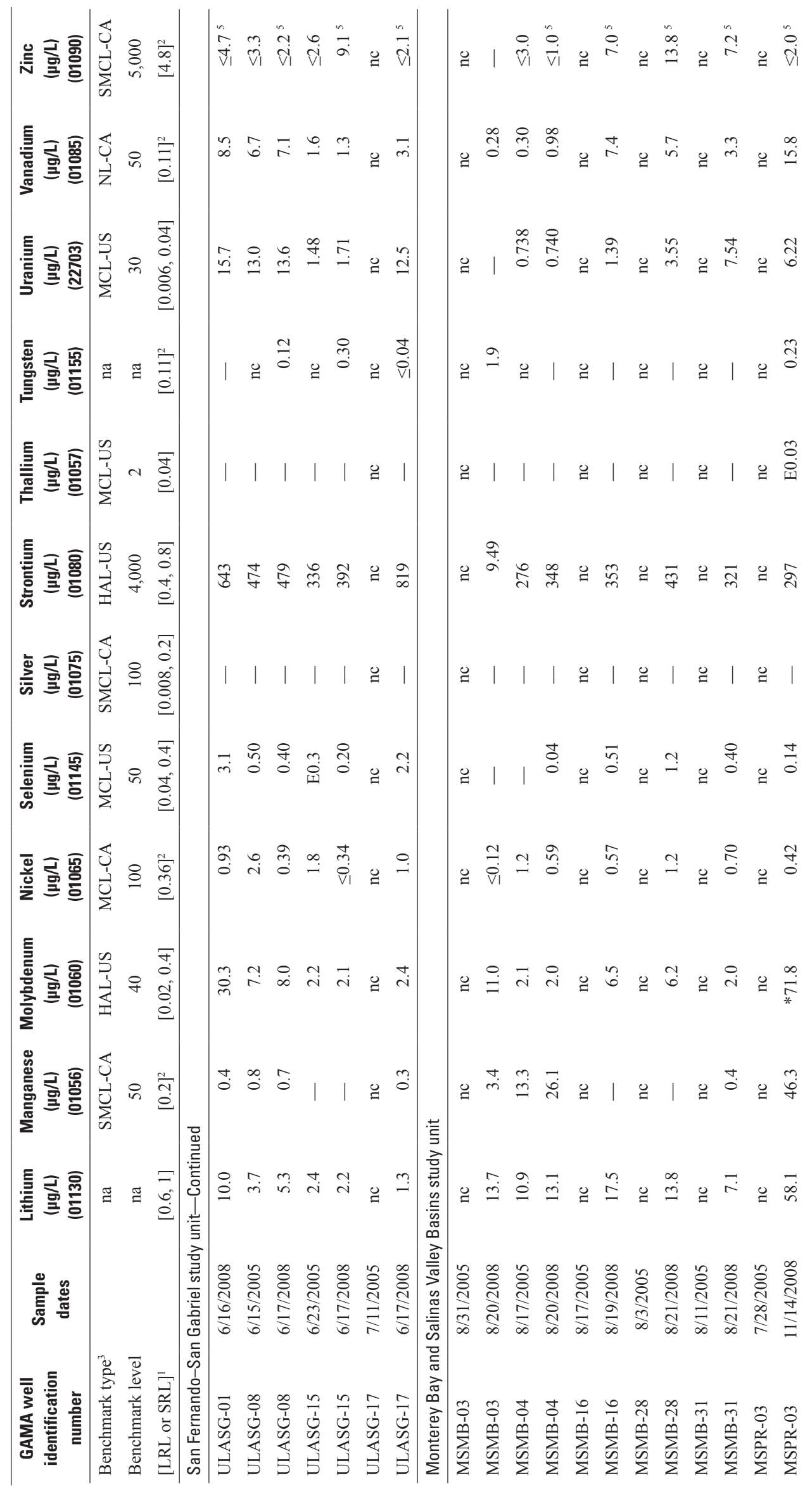




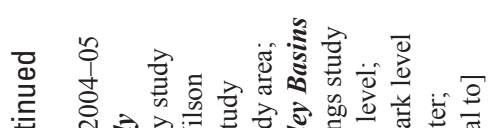

劳

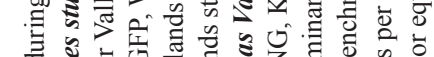

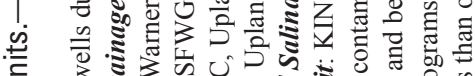

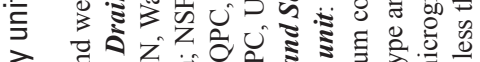

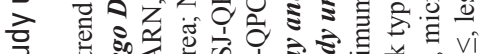

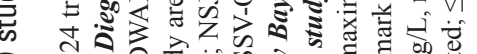

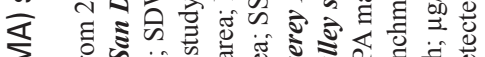

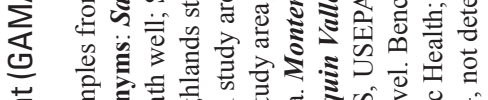

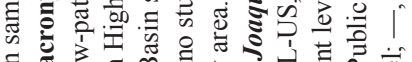

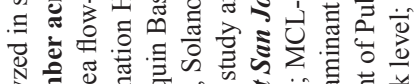

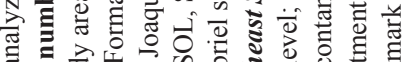

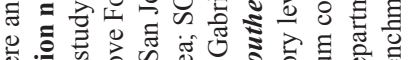

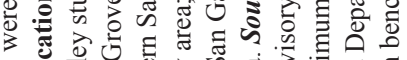

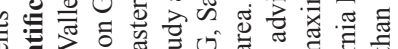

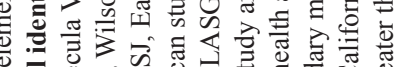

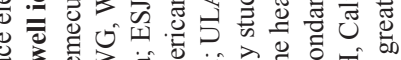

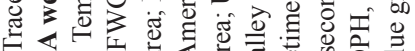

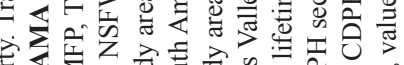

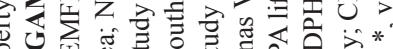

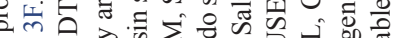

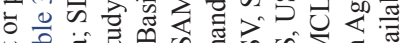

过 का की

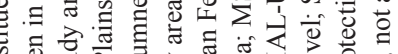

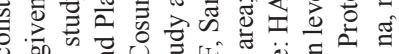

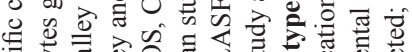

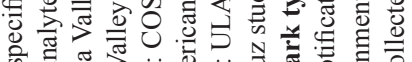

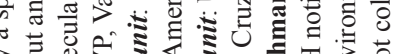

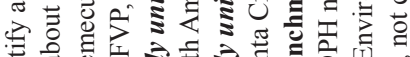

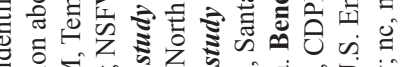

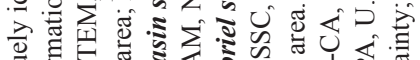

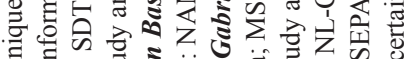

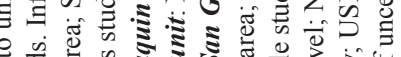

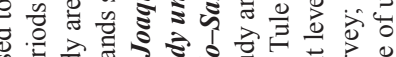

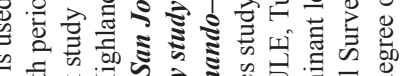

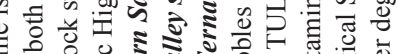

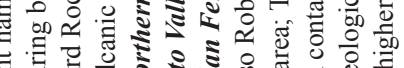

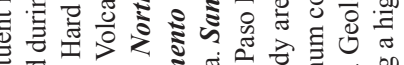

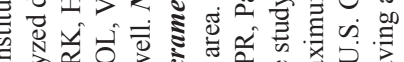

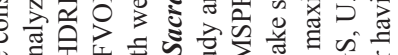

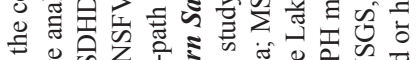

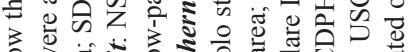

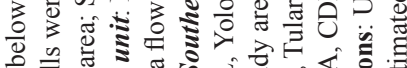

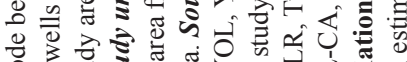

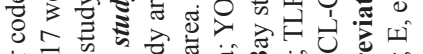

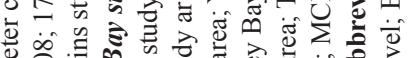

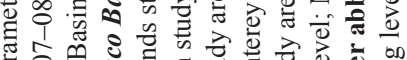

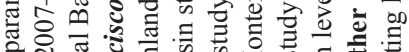

क

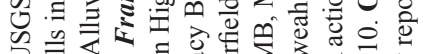

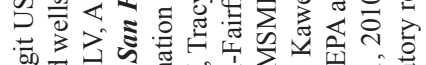

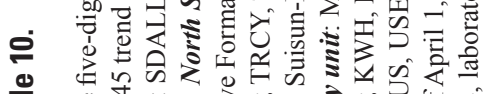

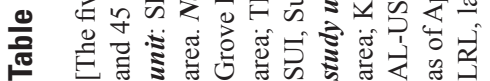

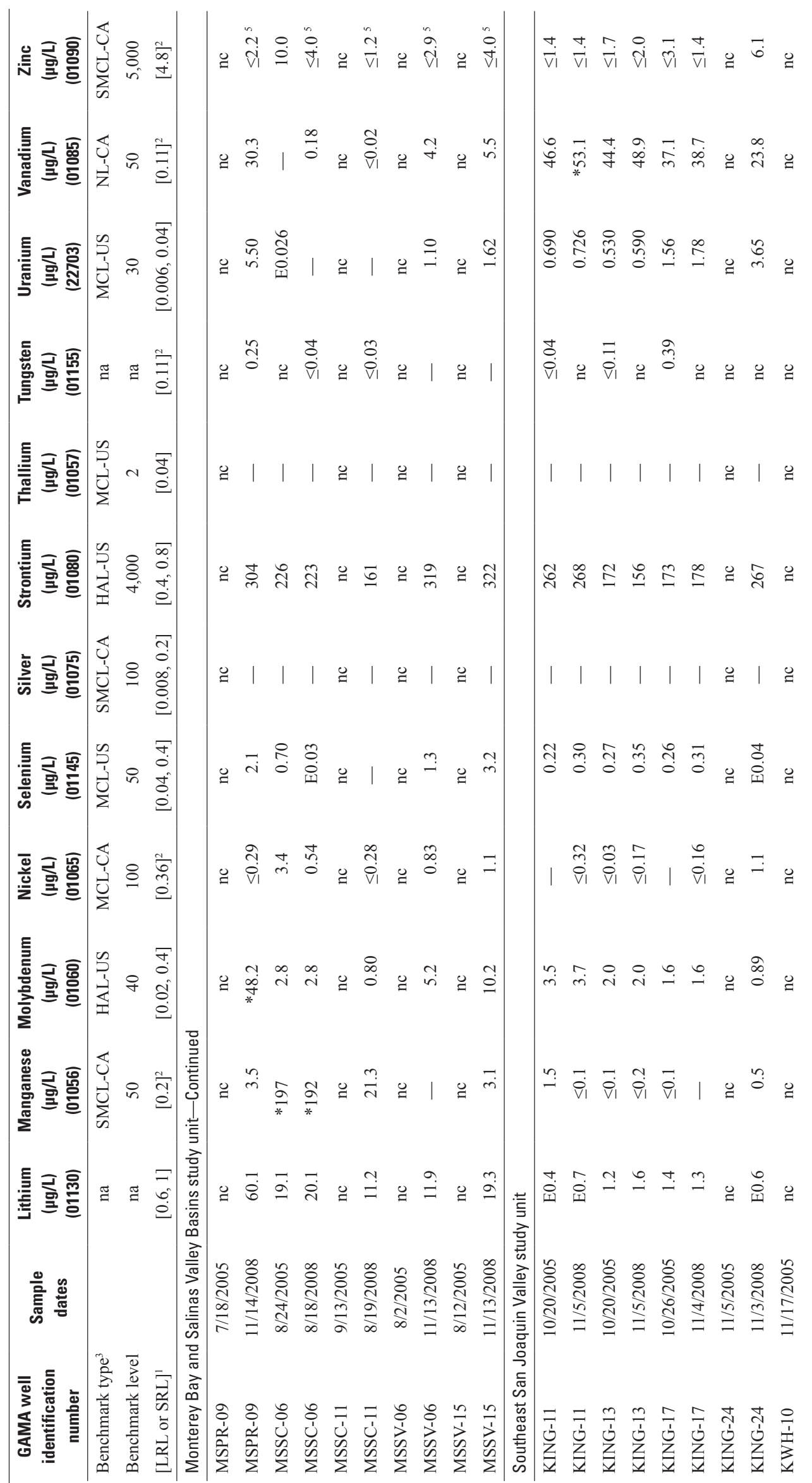




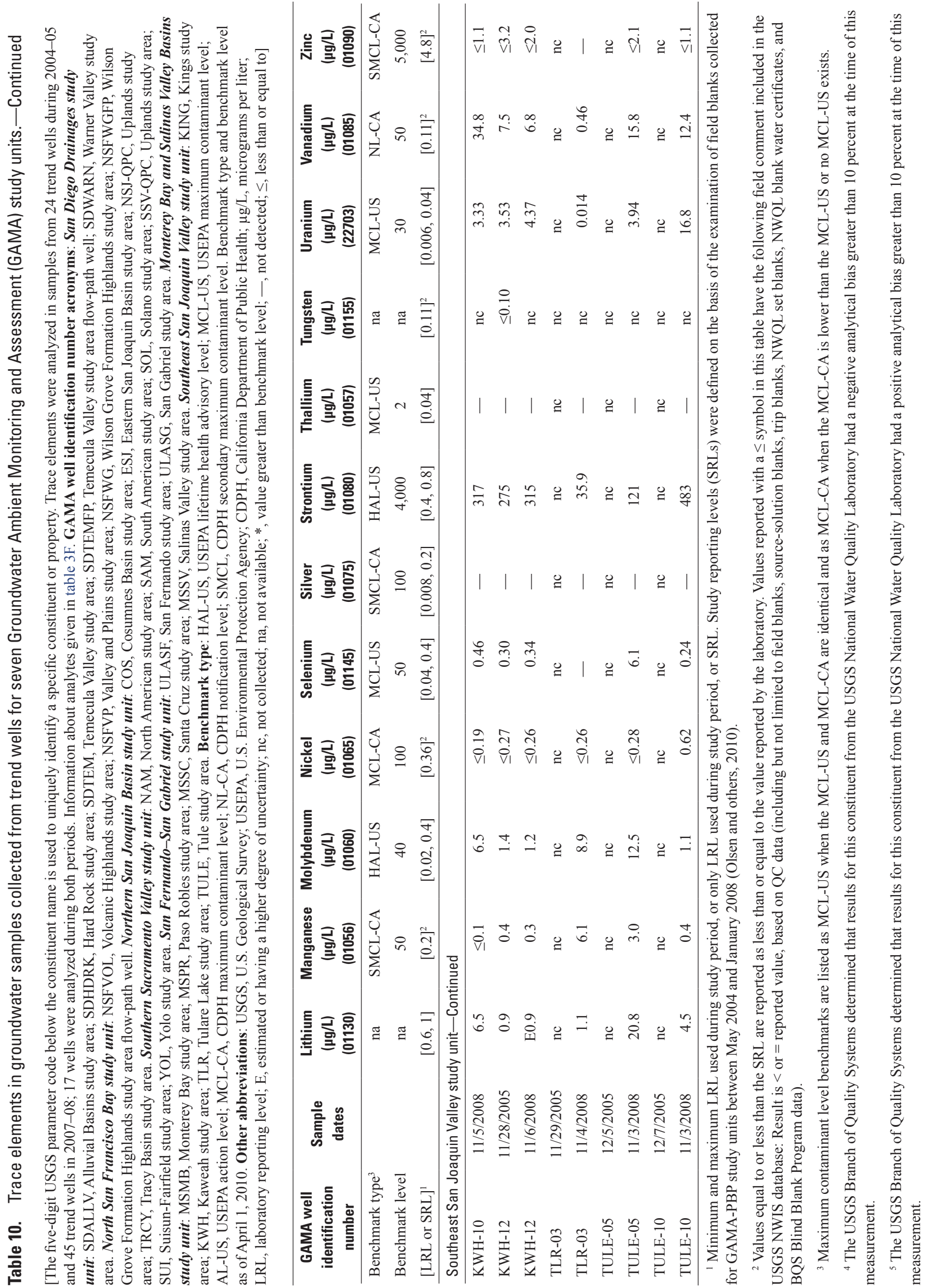


Table 11. Arsenic and iron oxidation-reduction species in samples collected from trend wells for seven Groundwater Ambient Monitoring and Assessment (GAMA) study units.

[The five-digit USGS parameter code below the constituent name is used to uniquely identify a specific constituent or property. Arsenic and iron oxidationreduction species were analyzed in samples from 21 trend wells during 2004-05 and 14 trend wells in 2007-08; 9 wells were analyzed during both periods. Only wells sampled in at least one period are listed. Information about analytes given in table 3G. GAMA well identification number acronyms: San Diego Drainages study unit: SDALLV, Alluvial Basins study area; SDHDRK, Hard Rock study area; SDTEM, Temecula Valley study area; SDTEMFP, Temecula Valley study area flow-path well; SDWARN, Warner Valley study area. North San Francisco Bay study unit: NSFVOL, Volcanic Highlands study area; NSFVP, Valley and Plains study area; NSFWG, Wilson Grove Formation Highlands study area; NSFWGFP, Wilson Grove Formation Highlands study area flow-path well. Northern San Joaquin Basin study unit: COS, Cosumnes Basin study area; ESJ, Eastern San Joaquin Basin study area; NSJ-QPC, Uplands study area; TRCY, Tracy Basin study area. Southern Sacramento Valley study unit: NAM, North American study area; SAM, South American study area; SOL, Solano study area; SSV-QPC, Uplands study area; SUI, Suisun-Fairfield study area; YOL, Yolo study area. San Fernando-San Gabriel study unit: ULASF, San Fernando study area; ULASG, San Gabriel study area. Monterey Bay and Salinas Valley Basins study unit: MSMB, Monterey Bay study area; MSPR, Paso Robles study area; MSSC, Santa Cruz study area; MSSV, Salinas Valley study area. Southeast San Joaquin Valley study unit: KING, Kings study area; KWH, Kaweah study area; TLR, Tulare Lake study area; TULE, Tule study area. Benchmark type: MCL-US, USEPA maximum contaminant level; SMCL-CA, California Department of Public Health secondary maximum contaminant level. Benchmark type and benchmark level as of April 1, 2010. Other abbreviations: USGS, U.S. Geological Survey; USEPA, U.S. Environmental Protection Agency; $\mu \mathrm{g} / \mathrm{L}$, micrograms per liter; MDL, method detection level; nc, not collected; na, not available; *, value greater than benchmark level; - , not detected]

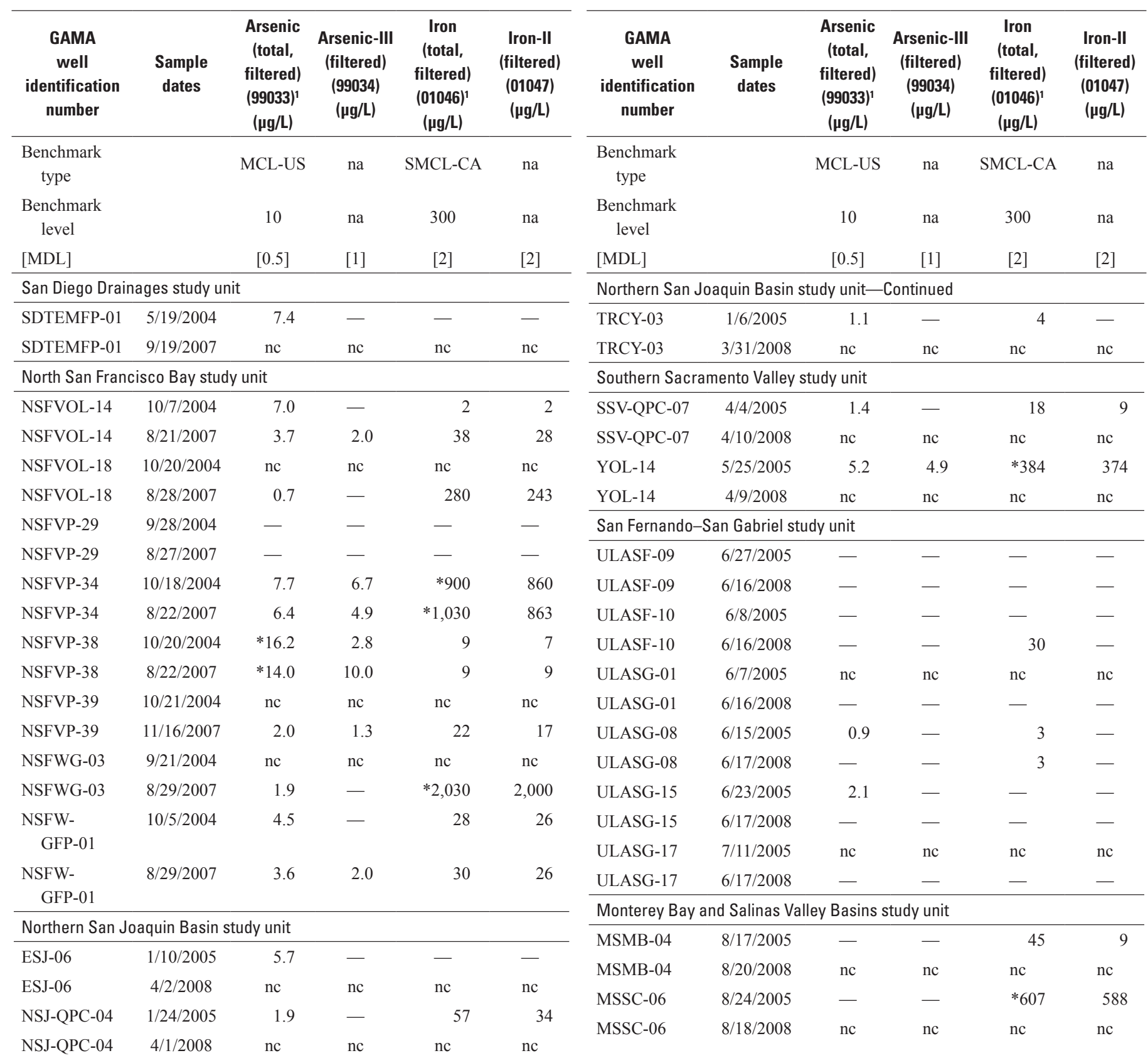


Table 11. Arsenic and iron oxidation-reduction species in samples collected from trend wells for seven Groundwater Ambient Monitoring and Assessment (GAMA) study units.

\section{-Continued}

[The five-digit USGS parameter code below the constituent name is used to uniquely identify a specific constituent or property. Arsenic and iron oxidation-reduction species were analyzed in samples from 21 trend wells during 2004-05 and 14 trend wells in 2007-08; 9 wells were analyzed during both periods. Only wells sampled in at least one period are listed. Information about analytes given in table $3 \mathrm{G}$. GAMA well identification number acronyms: San Diego Drainages study unit: SDALLV, Alluvial Basins study area; SDHDRK, Hard Rock study area; SDTEM, Temecula Valley study area; SDTEMFP, Temecula Valley study area flow-path well; SDWARN, Warner Valley study area. North San Francisco Bay study unit: NSFVOL, Volcanic Highlands study area; NSFVP, Valley and Plains study area; NSFWG, Wilson Grove Formation Highlands study area; NSFWGFP, Wilson Grove Formation Highlands study area flow-path well. Northern San Joaquin Basin study unit: COS, Cosumnes Basin study area; ESJ, Eastern San Joaquin Basin study area; NSJ-QPC, Uplands study area; TRCY, Tracy Basin study area. Southern Sacramento Valley study unit: NAM, North American study area; SAM, South American study area; SOL, Solano study area; SSV-QPC, Uplands study area; SUI, Suisun-Fairfield study area; YOL, Yolo study area. San Fernando-San Gabriel study unit: ULASF, San Fernando study area; ULASG, San Gabriel study area. Monterey Bay and Salinas Valley Basins study unit: MSMB, Monterey Bay study area; MSPR, Paso Robles study area; MSSC, Santa Cruz study area; MSSV, Salinas Valley study area. Southeast San Joaquin Valley study unit: KING, Kings study area; KWH, Kaweah study area; TLR, Tulare Lake study area; TULE, Tule study area. Benchmark type: MCL-US, USEPA maximum contaminant level; SMCL-CA, California Department of Public Health secondary maximum contaminant level. Benchmark type and benchmark level as of April 1, 2010. Other abbreviations: USGS, U.S. Geological Survey; USEPA, U.S. Environmental Protection Agency; $\mu \mathrm{g} / \mathrm{L}$, micrograms per liter; MDL, method detection level; nc, not collected; na, not available; *, value greater than benchmark level; —, not detected]

\begin{tabular}{|c|c|c|c|c|c|}
\hline $\begin{array}{c}\text { GAMA } \\
\text { well } \\
\text { identification } \\
\text { number }\end{array}$ & $\begin{array}{l}\text { Sample } \\
\text { dates }\end{array}$ & $\begin{array}{c}\text { Arsenic } \\
\text { (total, } \\
\text { filtered) } \\
(99033)^{1} \\
(\mu \mathrm{g} / \mathrm{L})\end{array}$ & $\begin{array}{c}\text { Arsenic-III } \\
\text { (filtered) } \\
(99034) \\
(\mu \mathrm{g} / \mathrm{L})\end{array}$ & $\begin{array}{c}\text { Iron } \\
\text { (total, } \\
\text { filtered) } \\
(01046)^{1} \\
(\mu \mathrm{g} / \mathrm{L})\end{array}$ & $\begin{array}{c}\text { Iron-II } \\
\text { (filtered) } \\
(01047) \\
(\mu \mathrm{g} / \mathrm{L})\end{array}$ \\
\hline $\begin{array}{l}\text { Benchmark } \\
\text { type }\end{array}$ & & MCL-US & na & SMCL-CA & na \\
\hline $\begin{array}{c}\text { Benchmark } \\
\text { level }\end{array}$ & & 10 & na & 300 & na \\
\hline [MDL] & & {$[0.5]$} & {$[1]$} & [2] & [2] \\
\hline \multicolumn{6}{|c|}{ Southeast San Joaquin Valley study unit } \\
\hline KING-11 & $10 / 20 / 2005$ & 1.1 & - & 6 & - \\
\hline KING-11 & $11 / 5 / 2008$ & $\mathrm{nc}$ & $\mathrm{nc}$ & $\mathrm{nc}$ & $\mathrm{nc}$ \\
\hline KING-13 & $10 / 20 / 2005$ & 1.5 & - & - & - \\
\hline KING-13 & $11 / 5 / 2008$ & $\mathrm{nc}$ & $\mathrm{nc}$ & $\mathrm{nc}$ & $\mathrm{nc}$ \\
\hline KING-17 & $10 / 26 / 2005$ & 1.5 & - & - & - \\
\hline KING-17 & $11 / 4 / 2008$ & $\mathrm{nc}$ & $\mathrm{nc}$ & $\mathrm{nc}$ & $\mathrm{nc}$ \\
\hline KWH-12 & $11 / 28 / 2005$ & - & - & - & - \\
\hline KWH-12 & $11 / 6 / 2008$ & $\mathrm{nc}$ & $\mathrm{nc}$ & $\mathrm{nc}$ & $\mathrm{nc}$ \\
\hline
\end{tabular}

${ }^{1}$ The preferred analytical method for this constituent is Laboratory Schedule 1948 (table 10). 
Table 12. Isotopic tracers in samples collected from trend wells for seven Groundwater Ambient Monitoring and Assessment (GAMA) study units.

[The five-digit USGS parameter code below the constituent name is used to uniquely identify a specific constituent or property. Stable isotope ratios of hydrogen, oxygen, and carbon are reported in delta notation $(\delta)$, the ratio of a heavier isotope to more common lighter isotope of that element, relative to a standard reference material. Tritium values less than the reporting level ${ }^{1}$ (MRL or ssL $)$ are reported as non-detections ( -). Stable isotopes of water were measured in 55 trend-well samples during both time periods. Tritium was analyzed in samples from 50 trend wells during 2004-05 and 55 trend wells in 200708. Carbon isotopes were analyzed in samples from 17 trend wells during 2004-05 and 29 trend wells in 2007-08; 9 wells were analyzed during both periods. Information about analytes given in table 3I. GAMA well identification number acronyms: San Diego Drainages study unit: SDALLV, Alluvial Basins study area; SDHDRK, Hard Rock study area; SDTEM, Temecula Valley study area; SDTEMFP, Temecula Valley study area flow-path well; SDWARN, Warner Valley study area. North San Francisco Bay study unit: NSFVOL, Volcanic Highlands study area; NSFVP, Valley and Plains study area; NSFWG, Wilson Grove Formation Highlands study area; NSFWGFP, Wilson Grove Formation Highlands study area flow-path well. Northern San Joaquin Basin study unit: COS, Cosumnes Basin study area; ESJ, Eastern San Joaquin Basin study area; NSJ-QPC, Uplands study area; TRCY, Tracy Basin study area. Southern Sacramento Valley study unit: NAM, North American study area; SAM, South American study area; SOL, Solano study area; SSV-QPC, Uplands study area; SUI, Suisun-Fairfield study area; YOL, Yolo study area. San Fernando-San Gabriel study unit: ULASF, San Fernando study area; ULASG, San Gabriel study area. Monterey Bay and Salinas Valley Basins study unit: MSMB, Monterey Bay study area; MSPR, Paso Robles study area; MSSC, Santa Cruz study area; MSSV, Salinas Valley study area. Southeast San Joaquin Valley study unit: KING, Kings study area; KWH, Kaweah study area; TLR, Tulare Lake study area; TULE, Tule study area. Benchmark type: MCL-CA, California Department of Public Health maximum contaminant level. Benchmark type and benchmark level as of April 1, 2010. Other abbreviations: USGS, U.S. Geological Survey; H, hydrogen; O, oxygen; C, carbon; CSU, 1-sigma combined standard uncertainty; $\mathrm{pCi} / \mathrm{L}$, picocuries per liter; $\mathrm{MRL}$, minimum reporting level; $\mathrm{ssL}_{\mathrm{c}}$, sample-specific critical level; \pm , plus or minus; nc, not collected; na, not available]

\begin{tabular}{|c|c|c|c|c|c|c|c|c|}
\hline $\begin{array}{c}\text { GAMA } \\
\text { identification } \\
\text { number }\end{array}$ & $\begin{array}{c}\text { Sample } \\
\text { dates }\end{array}$ & $\begin{array}{c}\delta^{2} \mathrm{H} \text { of water } \\
\text { (per mil) } \\
(\mathbf{8 2 0 8 2 )} \\
\end{array}$ & $\begin{array}{c}\delta^{18} 0 \text { of water } \\
\text { (per mil) } \\
(82085) \\
\end{array}$ & & $\begin{array}{l}\text { Tritium } \\
\text { (pCi/L) } \\
(07000) \\
\end{array}$ & & $\begin{array}{c}\delta^{13} \mathrm{C} \\
\text { (per mil) } \\
(82081)\end{array}$ & $\begin{array}{c}\text { Carbon-14 } \\
\text { (percent modern) } \\
(49933)\end{array}$ \\
\hline Benchmark type & & na & na & & MCL-CA & & na & na \\
\hline \multirow[t]{2}{*}{ Benchmark level } & & na & na & & 20,000 & & na & na \\
\hline & & & & $\begin{array}{c}\text { Result } \pm \\
\text { CSU }\end{array}$ & $\begin{array}{c}\text { Reporting } \\
\text { level }\end{array}$ & $\begin{array}{l}\text { Reporting } \\
\text { level type }\end{array}$ & & \\
\hline SDALLV-07 & $7 / 14 / 2004$ & -37.1 & -5.77 & $13.8 \pm 1$ & 1 & MRL & $\mathrm{nc}$ & $\mathrm{nc}$ \\
\hline SDALLV-07 & $9 / 12 / 2007$ & -36.1 & -5.90 & $10.2 \pm 1$ & 1 & MRL & $\mathrm{nc}$ & $\mathrm{nc}$ \\
\hline SDALLV-11 & $7 / 15 / 2004$ & -46.9 & -6.54 & $22.1 \pm 1.3$ & 1 & MRL & $\mathrm{nc}$ & $\mathrm{nc}$ \\
\hline SDALLV-11 & 9/13/2007 & -47.6 & -6.94 & $14.1 \pm 1.3$ & 1 & MRL & $\mathrm{nc}$ & $\mathrm{nc}$ \\
\hline SDHDRK-01 & $7 / 12 / 2004$ & -39.5 & -5.70 & $8.3 \pm 1$ & 1 & MRL & $\mathrm{nc}$ & $\mathrm{nc}$ \\
\hline SDTEM-04 & $5 / 24 / 2004$ & -46.0 & -5.90 & $10.6 \pm 1$ & 1 & MRL & $\mathrm{nc}$ & $\mathrm{nc}$ \\
\hline SDTEM-04 & 9/18/2007 & -66.6 & -8.43 & $12.4 \pm 1.3$ & 1 & MRL & -10.92 & 100 \\
\hline SDTEMFP-01 & $5 / 19 / 2004$ & -48.1 & -7.02 & - & 1 & MRL & -16.50 & 74 \\
\hline SDTEMFP-01 & $9 / 19 / 2007$ & -47.4 & -7.05 & - & 1 & MRL & -14.69 & 77 \\
\hline SDWARN-01 & $6 / 17 / 2004$ & -51.4 & -7.57 & - & 1 & MRL & $\mathrm{nc}$ & $\mathrm{nc}$ \\
\hline SDWARN-01 & 9/11/2007 & -50.4 & -7.44 & - & 1 & MRL & $\mathrm{nc}$ & $\mathrm{nc}$ \\
\hline \multicolumn{9}{|c|}{ North San Francisco Bay study unit } \\
\hline NSFVOL-14 & $10 / 7 / 2004$ & -39.9 & -6.12 & $4.2 \pm 0.6$ & 1 & MRL & -17.60 & 93 \\
\hline NSFVOL-14 & $8 / 21 / 2007$ & -38.4 & -5.66 & $6.1 \pm 1$ & 1 & MRL & -16.32 & 104 \\
\hline NSFVP-36 & $10 / 19 / 2004$ & -52.9 & -7.72 & - & 1 & MRL & $\mathrm{nc}$ & $\mathrm{nc}$ \\
\hline NSFVP-36 & $8 / 20 / 2007$ & -52.7 & -7.72 & - & 1 & MRL & -20.23 & 10 \\
\hline NSFVP-38 & $10 / 20 / 2004$ & -50.4 & -7.75 & - & 1 & MRL & -14.62 & 0.56 \\
\hline
\end{tabular}


Table 12. Isotopic tracers in samples collected from trend wells for seven Groundwater Ambient Monitoring and Assessment (GAMA) study units.-Continued

[The five-digit USGS parameter code below the constituent name is used to uniquely identify a specific constituent or property. Stable isotope ratios of hydrogen, oxygen, and carbon are reported in delta notation $(\delta)$, the ratio of a heavier isotope to more common lighter isotope of that element, relative to a standard reference material. Tritium values less than the reporting level ${ }^{1}\left(\mathrm{MRL}_{\mathrm{or}} \mathrm{ssL}_{\mathrm{c}}\right.$ ) are reported as non-detections (-). Stable isotopes of water were measured in 55 trend-well samples during both time periods. Tritium was analyzed in samples from 50 trend wells during 2004-05 and 55 trend wells in 200708. Carbon isotopes were analyzed in samples from 17 trend wells during 2004-05 and 29 trend wells in 2007-08; 9 wells were analyzed during both periods. Information about analytes given in table 3I. GAMA well identification number acronyms: San Diego Drainages study unit: SDALLV, Alluvial Basins study area; SDHDRK, Hard Rock study area; SDTEM, Temecula Valley study area; SDTEMFP, Temecula Valley study area flow-path well; SDWARN, Warner Valley study area. North San Francisco Bay study unit: NSFVOL, Volcanic Highlands study area; NSFVP, Valley and Plains study area; NSFWG, Wilson Grove Formation Highlands study area; NSFWGFP, Wilson Grove Formation Highlands study area flow-path well. Northern San Joaquin Basin study unit: COS, Cosumnes Basin study area; ESJ, Eastern San Joaquin Basin study area; NSJ-QPC, Uplands study area; TRCY, Tracy Basin study area. Southern Sacramento Valley study unit: NAM, North American study area; SAM, South American study area; SOL, Solano study area; SSV-QPC, Uplands study area; SUI, Suisun-Fairfield study area; YOL, Yolo study area. San Fernando-San Gabriel study unit: ULASF, San Fernando study area; ULASG, San Gabriel study area. Monterey Bay and Salinas Valley Basins study unit: MSMB, Monterey Bay study area; MSPR, Paso Robles study area; MSSC, Santa Cruz study area; MSSV, Salinas Valley study area. Southeast San Joaquin Valley study unit: KING, Kings study area; KWH, Kaweah study area; TLR, Tulare Lake study area; TULE, Tule study area. Benchmark type: MCL-CA, California Department of Public Health maximum contaminant level. Benchmark type and benchmark level as of April 1, 2010. Other abbreviations: USGS, U.S. Geological Survey; H, hydrogen; O, oxygen; C, carbon; CSU, 1-sigma combined standard uncertainty; $\mathrm{pCi} / \mathrm{L}$, picocuries per liter; $\mathrm{MRL}$, minimum reporting level; $\mathrm{ssL}_{\mathrm{c}}$, sample-specific critical level; \pm , plus or minus; nc, not collected; na, not available]

\begin{tabular}{|c|c|c|c|c|c|c|c|c|}
\hline $\begin{array}{c}\text { GAMA } \\
\text { identification } \\
\text { number }\end{array}$ & $\begin{array}{c}\text { Sample } \\
\text { dates }\end{array}$ & $\begin{array}{c}\delta^{2} \mathrm{H} \text { of water } \\
\text { (per mil) } \\
(82082)\end{array}$ & $\begin{array}{c}\delta^{18} 0 \text { of water } \\
\text { (per mil) } \\
\text { (82085) }\end{array}$ & & $\begin{array}{l}\text { Tritium } \\
\text { (pCi/L) } \\
(07000)\end{array}$ & & $\begin{array}{c}\delta^{13} \mathrm{C} \\
\text { (per mil) } \\
(82081)\end{array}$ & $\begin{array}{c}\text { Carbon-14 } \\
\text { (percent modern) } \\
\text { (49933) }\end{array}$ \\
\hline Benchmark type & & na & na & & MCL-CA & & na & na \\
\hline \multirow[t]{2}{*}{ Benchmark level } & & na & na & & 20,000 & & na & na \\
\hline & & & & $\begin{array}{c}\text { Result } \pm \\
\text { CSU }\end{array}$ & $\begin{array}{c}\text { Reporting } \\
\text { level }\end{array}$ & $\begin{array}{l}\text { Reporting } \\
\text { level type }\end{array}$ & & \\
\hline NSFVP-38 & $8 / 22 / 2007$ & -49.7 & -7.69 & - & 0.6 & MRL & -13.75 & 0.26 \\
\hline NSFVP-39 & $10 / 21 / 2004$ & -46.8 & -7.11 & $1.9 \pm 1$ & 1 & MRL & $\mathrm{nc}$ & $\mathrm{nc}$ \\
\hline NSFVP-39 & $11 / 16 / 2007$ & -48.2 & -7.01 & $1.9 \pm 0.8$ & 0.8 & MRL & -17.96 & 56 \\
\hline NSFVP-41 & $10 / 21 / 2004$ & -40.3 & -5.99 & $7.0 \pm 1$ & 1 & MRL & nc & $\mathrm{nc}$ \\
\hline NSFVP-41 & $8 / 20 / 2007$ & -39.7 & -6.03 & $3.5 \pm 0.6$ & 1 & MRL & -20.95 & 89 \\
\hline NSFWGFP-01 & $8 / 29 / 2007$ & -37.6 & -6.10 & $1.6 \pm 0.6$ & 0.6 & MRL & -15.36 & 41 \\
\hline \multicolumn{9}{|c|}{ Northern San Joaquin Basin study unit } \\
\hline COS-08 & $1 / 3 / 2005$ & -53.7 & -7.33 & - & 1 & MRL & $\mathrm{nc}$ & nc \\
\hline COS-08 & $4 / 3 / 2008$ & -53.7 & -7.27 & $\mathrm{na}^{2}$ & $\mathrm{na}^{2}$ & $\mathrm{na}^{2}$ & -15.72 & 31 \\
\hline ESJ-01 & $1 / 24 / 2005$ & -67.6 & -9.31 & $20.5 \pm 1.3$ & 1 & MRL & $\mathrm{nc}$ & $\mathrm{nc}$ \\
\hline ESJ-01 & $4 / 2 / 2008$ & -63.2 & -8.42 & $\mathrm{na}^{2}$ & $\mathrm{na}^{2}$ & $n a^{2}$ & -15.67 & 75 \\
\hline ESJ-06 & $1 / 10 / 2005$ & -63.5 & -8.86 & $7.4 \pm 1$ & 1 & MRL & $\mathrm{nc}$ & $\mathrm{nc}$ \\
\hline ESJ-06 & $4 / 2 / 2008$ & -65.8 & -8.94 & $4.5 \pm 0.35$ & 0.32 & $\mathrm{ssL}_{\mathrm{C}}$ & -15.20 & 80 \\
\hline NSJ-QPC-04 & $1 / 24 / 2005$ & -55.4 & -7.12 & $5.4 \pm 0.6$ & 1 & MRL & $\mathrm{nc}$ & $\mathrm{nc}$ \\
\hline SAM-10 & $4 / 21 / 2005$ & -50.1 & -6.94 & $4.5 \pm 1$ & 1 & MRL & $\mathrm{nc}$ & $\mathrm{nc}$ \\
\hline SAM-10 & 4/8/2008 & -50.4 & -7.08 & $4.4+0.32$ & 0.32 & $\mathrm{ssL}_{\mathrm{C}}$ & -18.07 & 99 \\
\hline SOL-08 & $5 / 10 / 2005$ & -48.4 & -7.19 & - & 1 & MRL & $\mathrm{nc}$ & $\mathrm{nc}$ \\
\hline
\end{tabular}


Table 12. Isotopic tracers in samples collected from trend wells for seven Groundwater Ambient Monitoring and Assessment (GAMA) study units.-Continued

[The five-digit USGS parameter code below the constituent name is used to uniquely identify a specific constituent or property. Stable isotope ratios of hydrogen, oxygen, and carbon are reported in delta notation $(\delta)$, the ratio of a heavier isotope to more common lighter isotope of that element, relative to a standard reference material. Tritium values less than the reporting level ${ }^{1}$ (MRL or ssL $)$ are reported as non-detections ( -). Stable isotopes of water were measured in 55 trend-well samples during both time periods. Tritium was analyzed in samples from 50 trend wells during $2004-05$ and 55 trend wells in $2007-$ 08. Carbon isotopes were analyzed in samples from 17 trend wells during 2004-05 and 29 trend wells in 2007-08; 9 wells were analyzed during both periods. Information about analytes given in table 3I. GAMA well identification number acronyms: San Diego Drainages study unit: SDALLV, Alluvial Basins study area; SDHDRK, Hard Rock study area; SDTEM, Temecula Valley study area; SDTEMFP, Temecula Valley study area flow-path well; SDWARN, Warner Valley study area. North San Francisco Bay study unit: NSFVOL, Volcanic Highlands study area; NSFVP, Valley and Plains study area; NSFWG, Wilson Grove Formation Highlands study area; NSFWGFP, Wilson Grove Formation Highlands study area flow-path well. Northern San Joaquin Basin study unit: COS, Cosumnes Basin study area; ESJ, Eastern San Joaquin Basin study area; NSJ-QPC, Uplands study area; TRCY, Tracy Basin study area. Southern Sacramento Valley study unit: NAM, North American study area; SAM, South American study area; SOL, Solano study area; SSV-QPC, Uplands study area; SUI, Suisun-Fairfield study area; YOL, Yolo study area. San Fernando-San Gabriel study unit: ULASF, San Fernando study area; ULASG, San Gabriel study area. Monterey Bay and Salinas Valley Basins study unit: MSMB, Monterey Bay study area; MSPR, Paso Robles study area; MSSC, Santa Cruz study area; MSSV, Salinas Valley study area. Southeast San Joaquin Valley study unit: KING, Kings study area; KWH, Kaweah study area; TLR, Tulare Lake study area; TULE, Tule study area. Benchmark type: MCL-CA, California Department of Public Health maximum contaminant level. Benchmark type and benchmark level as of April 1, 2010. Other abbreviations: USGS, U.S. Geological Survey; H, hydrogen; O, oxygen; C, carbon; CSU, 1-sigma combined standard uncertainty; $\mathrm{pCi} / \mathrm{L}$, picocuries per liter; $\mathrm{MRL}$, minimum reporting level; $\mathrm{ssL}_{\mathrm{c}}$, sample-specific critical level; \pm , plus or minus; nc, not collected; na, not available]

\begin{tabular}{|c|c|c|c|c|c|c|c|c|}
\hline $\begin{array}{c}\text { GAMA } \\
\text { identification } \\
\text { number }\end{array}$ & $\begin{array}{c}\text { Sample } \\
\text { dates }\end{array}$ & $\begin{array}{c}\delta^{2} \mathrm{H} \text { of water } \\
\text { (per mil) } \\
(82082)\end{array}$ & $\begin{array}{c}\delta^{18} 0 \text { of water } \\
\text { (per mil) } \\
(82085)\end{array}$ & & $\begin{array}{l}\text { Tritium } \\
\text { (pCi/L) } \\
(07000) \\
\end{array}$ & & $\begin{array}{c}\delta^{13} \mathrm{C} \\
\text { (per mil) } \\
(82081)\end{array}$ & $\begin{array}{c}\text { Carbon-14 } \\
\text { (percent modern) } \\
(49933)\end{array}$ \\
\hline Benchmark type & & na & na & & MCL-CA & & na & na \\
\hline \multirow[t]{2}{*}{ Benchmark level } & & na & na & & 20,000 & & na & na \\
\hline & & & & $\begin{array}{c}\text { Result } \pm \\
\text { CSU }\end{array}$ & $\begin{array}{c}\text { Reporting } \\
\text { level }\end{array}$ & $\begin{array}{l}\text { Reporting } \\
\text { level type }\end{array}$ & & \\
\hline SOL-08 & $4 / 8 / 2008$ & -50.6 & -7.08 & - & 0.32 & $\mathrm{ssL}_{\mathrm{C}}$ & -14.65 & 48 \\
\hline SSV-QPC-07 & $4 / 4 / 2005$ & -52.7 & -7.40 & $1.3 \pm 1$ & 1 & MRL & -17.00 & 77 \\
\hline SSV-QPC-07 & $4 / 10 / 2008$ & -55.5 & -7.46 & $1.7 \pm 0.38$ & 0.35 & $\mathrm{ssL}_{\mathrm{C}}$ & $\mathrm{nc}$ & $\mathrm{nc}$ \\
\hline SUI-03 & $5 / 12 / 2005$ & -45.2 & -6.46 & - & 1 & MRL & nc & $\mathrm{nc}$ \\
\hline SUI-03 & $4 / 9 / 2008$ & & -6.40 & $0.6 \pm 0.35$ & 0.35 & $\mathrm{ssL}_{\mathrm{C}}$ & -13.15 & 62 \\
\hline YOL-14 & 4/9/2008 & -63.9 & -8.40 & $2.2 \pm 0.32$ & 0.32 & $\mathrm{ssL}_{\mathrm{C}}$ & $\mathrm{nc}$ & $\mathrm{nc}$ \\
\hline \multicolumn{9}{|c|}{ San Fernando-San Gabriel study unit } \\
\hline ULASF-09 & $6 / 27 / 2005$ & -54.5 & -7.61 & $20.5 \pm 1.6$ & 1 & MRL & -16.00 & 100 \\
\hline ULASF-09 & $6 / 16 / 2008$ & -53.8 & -7.79 & $16.9 \pm 0.67$ & 0.38 & $\mathrm{ssL}_{\mathrm{C}}$ & $\mathrm{nc}$ & nc \\
\hline ULASF-10 & $6 / 8 / 2005$ & -51.6 & -7.66 & $3.8 \pm 0.6$ & 1 & MRL & -14.90 & 79 \\
\hline ULASF-10 & $6 / 16 / 2008$ & -47.2 & -7.25 & $0.6 \pm 0.45$ & 0.45 & $\mathrm{ssL}_{\mathrm{C}}$ & $\mathrm{nc}$ & $\mathrm{nc}$ \\
\hline ULASG-01 & $6 / 7 / 2005$ & -45.4 & -6.45 & $8.0 \pm 0.6$ & 1 & MRL & $\mathrm{nc}$ & $\mathrm{nc}$ \\
\hline ULASG-01 & $6 / 16 / 2008$ & -44.7 & -6.57 & $8.9 \pm 0.48$ & 0.35 & $\mathrm{ssL}_{\mathrm{C}}$ & $\mathrm{nc}$ & $\mathrm{nc}$ \\
\hline ULASG-08 & $6 / 15 / 2005$ & -47.6 & -7.20 & $6.1 \pm 0.6$ & 1 & MRL & -14.90 & 93 \\
\hline MSMB-03 & $8 / 31 / 2005$ & -50.7 & -7.38 & - & 1 & MRL & $\mathrm{nc}$ & $\mathrm{nc}$ \\
\hline MSMB-03 & $8 / 20 / 2008$ & -50.7 & -7.42 & - & 0.32 & $\mathrm{ssL}_{\mathrm{C}}$ & -15.68 & 5.4 \\
\hline MSMB-04 & $8 / 17 / 2005$ & -45.9 & -7.32 & $2.2 \pm 1$ & 1 & MRL & -15.50 & 5.7 \\
\hline
\end{tabular}


Table 12. Isotopic tracers in samples collected from trend wells for seven Groundwater Ambient Monitoring and Assessment (GAMA) study units.-Continued

[The five-digit USGS parameter code below the constituent name is used to uniquely identify a specific constituent or property. Stable isotope ratios of hydrogen, oxygen, and carbon are reported in delta notation $(\delta)$, the ratio of a heavier isotope to more common lighter isotope of that element, relative to a standard reference material. Tritium values less than the reporting level ${ }^{1}\left(\mathrm{MRL}_{\mathrm{or}} \mathrm{ssL}_{\mathrm{c}}\right.$ ) are reported as non-detections (-). Stable isotopes of water were measured in 55 trend-well samples during both time periods. Tritium was analyzed in samples from 50 trend wells during 2004-05 and 55 trend wells in 200708. Carbon isotopes were analyzed in samples from 17 trend wells during 2004-05 and 29 trend wells in 2007-08; 9 wells were analyzed during both periods. Information about analytes given in table 3I. GAMA well identification number acronyms: San Diego Drainages study unit: SDALLV, Alluvial Basins study area; SDHDRK, Hard Rock study area; SDTEM, Temecula Valley study area; SDTEMFP, Temecula Valley study area flow-path well; SDWARN, Warner Valley study area. North San Francisco Bay study unit: NSFVOL, Volcanic Highlands study area; NSFVP, Valley and Plains study area; NSFWG, Wilson Grove Formation Highlands study area; NSFWGFP, Wilson Grove Formation Highlands study area flow-path well. Northern San Joaquin Basin study unit: COS, Cosumnes Basin study area; ESJ, Eastern San Joaquin Basin study area; NSJ-QPC, Uplands study area; TRCY, Tracy Basin study area. Southern Sacramento Valley study unit: NAM, North American study area; SAM, South American study area; SOL, Solano study area; SSV-QPC, Uplands study area; SUI, Suisun-Fairfield study area; YOL, Yolo study area. San Fernando-San Gabriel study unit: ULASF, San Fernando study area; ULASG, San Gabriel study area. Monterey Bay and Salinas Valley Basins study unit: MSMB, Monterey Bay study area; MSPR, Paso Robles study area; MSSC, Santa Cruz study area; MSSV, Salinas Valley study area. Southeast San Joaquin Valley study unit: KING, Kings study area; KWH, Kaweah study area; TLR, Tulare Lake study area; TULE, Tule study area. Benchmark type: MCL-CA, California Department of Public Health maximum contaminant level. Benchmark type and benchmark level as of April 1, 2010. Other abbreviations: USGS, U.S. Geological Survey; H, hydrogen; O, oxygen; C, carbon; CSU, 1-sigma combined standard uncertainty; $\mathrm{pCi} / \mathrm{L}$, picocuries per liter; $\mathrm{MRL}$, minimum reporting level; $\mathrm{ssL}_{\mathrm{c}}$, sample-specific critical level; \pm , plus or minus; nc, not collected; na, not available]

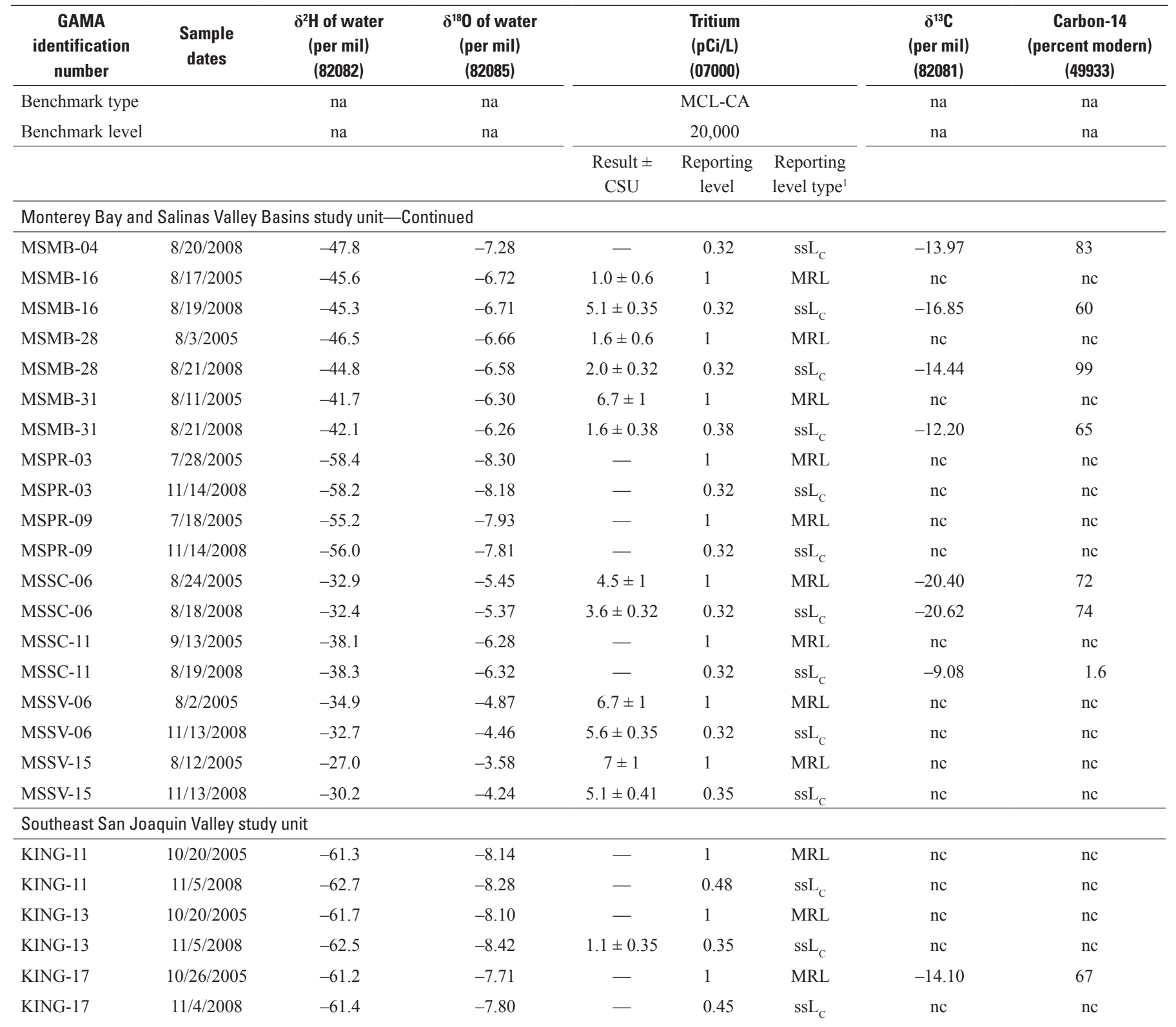


Table 12. Isotopic tracers in samples collected from trend wells for seven Groundwater Ambient Monitoring and Assessment (GAMA) study units. - Continued

[The five-digit USGS parameter code below the constituent name is used to uniquely identify a specific constituent or property. Stable isotope ratios of hydrogen, oxygen, and carbon are reported in delta notation $(\delta)$, the ratio of a heavier isotope to more common lighter isotope of that element, relative to a standard reference material. Tritium values less than the reporting level ${ }^{1}$ (MRL or ssL $)$ are reported as non-detections ( -). Stable isotopes of water were measured in 55 trend-well samples during both time periods. Tritium was analyzed in samples from 50 trend wells during 2004-05 and 55 trend wells in 200708. Carbon isotopes were analyzed in samples from 17 trend wells during 2004-05 and 29 trend wells in 2007-08; 9 wells were analyzed during both periods. Information about analytes given in table 3I. GAMA well identification number acronyms: San Diego Drainages study unit: SDALLV, Alluvial Basins study area; SDHDRK, Hard Rock study area; SDTEM, Temecula Valley study area; SDTEMFP, Temecula Valley study area flow-path well; SDWARN, Warner Valley study area. North San Francisco Bay study unit: NSFVOL, Volcanic Highlands study area; NSFVP, Valley and Plains study area; NSFWG, Wilson Grove Formation Highlands study area; NSFWGFP, Wilson Grove Formation Highlands study area flow-path well. Northern San Joaquin Basin study unit: COS, Cosumnes Basin study area; ESJ, Eastern San Joaquin Basin study area; NSJ-QPC, Uplands study area; TRCY, Tracy Basin study area. Southern Sacramento Valley study unit: NAM, North American study area; SAM, South American study area; SOL, Solano study area; SSV-QPC, Uplands study area; SUI, Suisun-Fairfield study area; YOL, Yolo study area. San Fernando-San Gabriel study unit: ULASF, San Fernando study area; ULASG, San Gabriel study area. Monterey Bay and Salinas Valley Basins study unit: MSMB, Monterey Bay study area; MSPR, Paso Robles study area; MSSC, Santa Cruz study area; MSSV, Salinas Valley study area. Southeast San Joaquin Valley study unit: KING, Kings study area; KWH, Kaweah study area; TLR, Tulare Lake study area; TULE, Tule study area. Benchmark type: MCL-CA, California Department of Public Health maximum contaminant level. Benchmark type and benchmark level as of April 1, 2010. Other abbreviations: USGS, U.S. Geological Survey; H, hydrogen; O, oxygen; C, carbon; CSU, 1-sigma combined standard uncertainty; $\mathrm{pCi} / \mathrm{L}$, picocuries per liter; $\mathrm{MRL}$, minimum reporting level; $\mathrm{ssL}_{\mathrm{c}}$, sample-specific critical level; \pm , plus or minus; nc, not collected; na, not available]

\begin{tabular}{|c|c|c|c|c|c|c|c|c|}
\hline $\begin{array}{c}\text { GAMA } \\
\text { identification } \\
\text { number }\end{array}$ & $\begin{array}{c}\text { Sample } \\
\text { dates }\end{array}$ & $\begin{array}{c}\delta^{2} \mathrm{H} \text { of water } \\
\text { (per mil) } \\
(82082)\end{array}$ & $\begin{array}{c}\delta^{18} 0 \text { of water } \\
\text { (per mil) } \\
(82085)\end{array}$ & & $\begin{array}{l}\text { Tritium } \\
\text { (pCi/L) } \\
(07000) \\
\end{array}$ & & $\begin{array}{c}\delta^{13} \mathrm{C} \\
\text { (per mil) } \\
(82081)\end{array}$ & $\begin{array}{c}\text { Carbon-14 } \\
\text { (percent modern) } \\
(49933)\end{array}$ \\
\hline Benchmark type & & na & na & & MCL-CA & & na & na \\
\hline \multirow[t]{2}{*}{ Benchmark level } & & na & na & & 20,000 & & na & na \\
\hline & & & & $\begin{array}{c}\text { Result } \pm \\
\text { CSU }\end{array}$ & $\begin{array}{c}\text { Reporting } \\
\text { level }\end{array}$ & $\begin{array}{l}\text { Reporting } \\
\text { level type }\end{array}$ & & \\
\hline KING-24 & $11 / 5 / 2005$ & -85.2 & -11.50 & $\mathrm{nc}$ & $\mathrm{nc}$ & $\mathrm{nc}$ & $\mathrm{nc}$ & $\mathrm{nc}$ \\
\hline KING-24 & $11 / 3 / 2008$ & -86.5 & -11.68 & $17.3 \pm 0.70$ & 0.35 & $\mathrm{ssL}_{\mathrm{C}}$ & nc & $\mathrm{nc}$ \\
\hline KWH-10 & $11 / 17 / 2005$ & -64.0 & -7.84 & $\mathrm{nc}$ & nc & $\mathrm{nc}$ & $\mathrm{nc}$ & $\mathrm{nc}$ \\
\hline KWH-10 & $11 / 5 / 2008$ & -64.8 & -8.01 & $10.0 \pm 0.51$ & 0.35 & $\mathrm{ssL}_{\mathrm{C}}$ & $\mathrm{nc}$ & $\mathrm{nc}$ \\
\hline KWH-12 & $11 / 28 / 2005$ & -87.2 & -12.21 & $16 \pm 1.6$ & 1 & MRL & -15.30 & 86 \\
\hline TULE-05 & $12 / 5 / 2005$ & -68.4 & -8.66 & $\mathrm{nc}$ & nc & $\mathrm{nc}$ & $\mathrm{nc}$ & $\mathrm{nc}$ \\
\hline TULE-05 & $11 / 3 / 2008$ & -64.3 & -7.90 & $0.9 \pm 0.32$ & 0.32 & $\mathrm{ssL}_{\mathrm{C}}$ & $\mathrm{nc}$ & $\mathrm{nc}$ \\
\hline TULE-10 & $12 / 7 / 2005$ & -72.9 & -10.30 & $\mathrm{nc}$ & $\mathrm{nc}$ & $\mathrm{nc}$ & nc & $\mathrm{nc}$ \\
\hline TULE-10 & $11 / 3 / 2008$ & -71.4 & -10.10 & $4.5 \pm 0.32$ & 0.32 & $\mathrm{ssL}_{\mathrm{C}}$ & $\mathrm{nc}$ & $\mathrm{nc}$ \\
\hline
\end{tabular}

${ }^{1}$ Tritium reporting levels were expressed as MRL before August 2008 and as $\mathrm{ssL}_{\mathrm{c}}$ after August 2008 (both reporting level types were used during August 2008).

${ }^{2}$ Result was rejected after quality-assurance review. 


\section{Appendix}

This appendix includes discussions of the methods used to collect and analyze groundwater samples and report the resulting water-quality data. Methods used during initial sampling are described in published GAMA Data Series Reports for each study unit (Wright and others, 2005; Kulongoski and others, 2006; Bennett and others, 2006; Dawson and others, 2008; Land and Belitz, 2008; Kulongoski and Belitz, 2007; and Burton and Belitz, 2008). In each case, the methods were selected to obtain representative samples of the groundwater from each well and to minimize the potential for contamination of the samples or bias in the data. Procedures used to collect and assess QC data and the results of the QC assessments for the resampled trend wells also are discussed.

Groundwater samples were collected and QA procedures were implemented using standard and modified USGS protocols from the NFM (U.S. Geological Survey, variously dated; Wilde and others, 1999, 2004) and the NAWQA Program (Koterba and others, 1995). The QA plan followed by the NWQL, the primary laboratory used to analyze samples for this study, is described in Maloney (2005) and Pirkey and Glodt (1998).

\section{Sample Collection and Analysis}

Prior to sampling, wells were pumped continuously until field measurements of water temperature, dissolved oxygen, $\mathrm{pH}$, and specific conductance were stable (Wilde and others, 1999). Wells were sampled using Teflon ${ }^{\circledR}$ tubing with brass and stainless-steel fittings attached to a sampling point (usually a hose-bib fitting) on the well-discharge pipe as close to the well head as possible. The sampling point was located upstream from water-storage tanks and from the well-head treatment system (if a system existed). If a chlorinating system was attached to the well, the chlorinator was shut off, when possible, before the well was purged and sampled in order to clear all chlorine out of the system. The absence of free chlorine was verified using a $\mathrm{Hach}^{\circledR}$ field test kit. All samples were collected outdoors by connecting a 1 - to 3 -foot length of Teflon ${ }^{\circledR}$ tubing to the sampling point (Lane and others, 2003). All fittings and lengths of tubing were cleaned between samples (Wilde, 2004).

For the field measurements, groundwater was pumped through a flow-through chamber (that was attached to the sampling point) fitted with a multi-probe meter that simultaneously measured the field water-quality indicatorsdissolved oxygen, temperature, $\mathrm{pH}$, and specific conductance. Field measurements were made in accordance with protocols in the NFM (Radtke and others, 2005; Wilde and Radtke, 2005; Lewis, 2006; Wilde, 2006; Wilde and others, 2006). All sensors on the multi-probe meter were calibrated daily.
Measured dissolved oxygen, temperature, $\mathrm{pH}$, and specific conductance values were recorded at approximately 5-minute (min) intervals, and when these values remained stable for a minimum of $30 \mathrm{~min}$, samples for laboratory analyses then were collected.

Field measurements and instrument calibrations were recorded by hand on field record sheets and electronically in the Personal Computer Field Form (PCFF) program. Analytical service requests for the NWQL also were managed by PCFF, whereas analytical service requests for other laboratories were entered into laboratory-specific spreadsheets. Information from PCFF was uploaded directly into NWIS at the end of every week of sample collection.

Detailed sampling protocols for individual analyses and groups of analytes are described in Koterba and others (1995), in the NFM (Wilde and others, 1999, 2004), and in the references for analytical methods listed in table A1; only brief descriptions are given here. VOC samples were collected in three 40-millilter $(\mathrm{mL})$ sample vials that were purged with three vial volumes of unfiltered groundwater before bottomfilling to eliminate atmospheric contamination. One to one (1:1) hydrochloric acid to water $\left(\mathrm{HCl} / \mathrm{H}_{2} \mathrm{O}\right)$ solution was added as a preservative to the VOC samples. Perchlorate samples were collected in $125-\mathrm{mL}$ polystyrene bottles and then filtered in two or three $20-\mathrm{mL}$ aliquots of groundwater through a 0.20 -micrometer $(\mu \mathrm{m})$ pore-size Corning ${ }^{\circledR}$ syringetip disk filter into sterilized 125 -mL bottles. Tritium samples were collected by bottom-filling one 1-L polyethylene bottle with unfiltered groundwater, after first overfilling the bottles with three volumes of unfiltered groundwater. Samples for analysis of stable isotopes of hydrogen and oxygen in water were each collected in a $60-\mathrm{mL}$ clear glass bottle filled with unfiltered groundwater, sealed with a conical cap, and secured with electrical tape to prevent leakage and evaporation.

Samples for analysis of pesticides (including polar pesticides) and pesticide degradates were collected in 1-L baked amber glass bottles. These samples were each filtered through a $0.7-\mu \mathrm{m}$ nominal pore-size glass fiber filter during collection. NDMA samples were collected in $500-\mathrm{mL}$ baked amber bottles treated with 0.05 gram $(\mathrm{g})$ of sodium thiosulfate $\left(\mathrm{Na}_{2} \mathrm{~S}_{2} \mathrm{O}_{3}\right)$ as a preservative and were filtered at Weck prior to analysis.

Groundwater samples for trace elements, major and minor ions, silica, laboratory alkalinity, and TDS analyses required filling one $250-\mathrm{mL}$ polyethylene bottle with unfiltered groundwater and one $500-\mathrm{mL}$ and one $250-\mathrm{mL}$ polyethylene bottle with filtered groundwater (Wilde and others, 2004). Filtration was done using a $0.45-\mu \mathrm{m}$ pore-size PALL $^{\circledR}$ unvented capsule filter that was pre-rinsed with $2 \mathrm{~L}$ of deionized water, then rinsed with $1 \mathrm{~L}$ of groundwater prior to sampling. The $250-\mathrm{mL}$ filtered sample to be analyzed for trace elements was preserved with 7.5-Normal (N) nitric acid. Nutrient samples were collected by filtering groundwater into $125-\mathrm{mL}$ brown polyethylene bottles. Arsenic and iron 
species samples were filtered into $250-\mathrm{mL}$ polyethylene bottles that were covered with tape to prevent light exposure and preserved with 6-N hydrochloric acid. Stable isotopes of carbon in dissolved inorganic carbon and carbon-14 abundance samples were filtered and bottom-filled into $500-\mathrm{mL}$ glass bottles that first were overfilled with three bottle volumes of filtered groundwater. These samples had no headspace and were sealed with conical caps to avoid atmospheric contamination. Bicarbonate and carbonate concentrations were calculated from the laboratory alkalinity and $\mathrm{pH}$ values using the advanced speciation method (http:// or.water.usgs.gov/alk/methods.html) with $\mathrm{pK}_{1}=6.35, \mathrm{pK}_{2}=$ 10.33 , and $\mathrm{pK}_{\mathrm{W}}=14$.

Temperature-sensitive samples were stored on ice prior to and during shipping to the various laboratories. The non-temperature-sensitive samples for tritium and stable isotopes of hydrogen and oxygen in water were shipped monthly. Temperature-sensitive or time-sensitive samples for VOCs, pesticides (including polar pesticides) and pesticide degradates, perchlorate, NDMA, trace elements, nutrients, major and minor ions, silica, TDS, and laboratory alkalinity were shipped daily whenever possible. Samples to be analyzed for arsenic and iron species were shipped weekly. The temperature-sensitive samples for stable isotopes of carbon in dissolved inorganic carbon and carbon-14 abundance were stored on ice, archived in a laboratory refrigerator, and shipped after all of the laboratory alkalinity measurements were received.

Seven laboratories performed chemical analyses on samples collected during resampling for trends (table A1), although most of the analyses were performed at the NWQL. The NWQL maintains a rigorous QA program (Pirkey and Glodt, 1998; Maloney, 2005). Laboratory QC samples, including method blanks, continuing calibration verification standards, standard reference samples, reagent spikes of target analytes and surrogates, external certified reference materials, and external blind proficiency samples are analyzed regularly. Method detection limits are tested continuously and laboratory reporting levels updated accordingly. NWQL maintains National Environmental Laboratory Accreditation Program (NELAP) and other certifications (http://www.nelac-institute. org/accred-labs.php). The USGS Branch of Quality Systems (BQS) maintains independent oversight of QA at the NWQL. The BQS also runs the National Field Quality Assurance Program (NFQA) that includes annual testing of all USGS field personnel for proficiency in making field water-quality measurements (http://qadata.cr.usgs.gov/nfqa/). Results for analyses made at the NWQL or by laboratories contracted by the NWQL are uploaded directly into the USGS NWIS database. Results of analyses made at other laboratories are compiled in a project database and uploaded from there into the USGS NWIS database.

\section{Data Reporting}

The following section gives details for the laboratory reporting conventions and the constituents sampled for trends that are determined by multiple methods or by multiple laboratories.

\section{Reporting Limits}

The USGS NWQL uses different conventions for reporting results for organic and inorganic constituents. For organic constituents, LRLs and LT-MDLs are used as thresholds for reporting analytical results. The LRL is set to minimize the reporting of false negatives (not detecting a compound when it actually is present in a sample) to less than 1 percent (Childress and others, 1999). The LRL usually is set at two times the LT-MDL. The LT-MDL is derived from the standard deviation of at least 24 method detection limit (MDL) determinations made over an extended period of time. The MDL is the minimum concentration of a substance that can be measured and reported with 99-percent confidence that the concentration is greater than zero (at the MDL, there is less than a 1 percent chance of a false positive) (Childress and others, 1999; U.S. Environmental Protection Agency, 2002). Inorganic detections at concentrations less than the LT-MDL are reported as non-detections with a dash (-) in the data tables. The USGS NWQL updates LRL and LT-MDL values regularly, and the values or ranges of values listed in this report were in effect during the initial sampling period (May 2004 to February 2006) and the resampling period (September 2007 to November 2008) for trend wells from the first seven GAMA-PBP study units.

For organic constituents, concentrations between the LRL and the LT-MDL are reported as having a higher degree of uncertainty (coded by the letter "E" preceding the values in the tables and text). For information-rich methods, detections less than the LT-MDL have a high certainty of presence, but the precise concentration is uncertain. Detections of organic compounds at concentrations less than the LT-MDL are reported in the data tables, but are qualified with E-code remarks and footnotes, and are not considered detections in the calculations of detection statistics. Information-rich methods are those that use gas chromatography or highperformance liquid chromatography (HPLC) with mass spectrometry detection, such as those methods used to analyze VOCs and pesticides. Compounds are identified by presence of characteristic fragmentation patterns in their mass spectra in addition to being quantified by measurement of peak areas at their associated chromatographic retention times. E-coded values also may result from detections outside the range of calibration standards, from detections that did not meet all laboratory QC criteria, and from samples that were diluted prior to analysis (Childress and others, 1999). 
Total dissolved solids, perchlorate, and NDMA are reported by using minimum reporting levels (MRLs). The MRL is the smallest measurable concentration of a constituent that may be reliably reported using a given analytical method (Timme, 1995).

The reporting limits for radiochemical constituents (carbon-14 and tritium) are based on sample-specific critical levels $\left(\mathrm{ssL}_{\mathrm{C}}\right)$ (McCurdy and others, 2008). The critical level is analogous to the LT-MDL used for reporting analytical results for organic and non-radioactive inorganic constituents. Here, the critical level is defined as the minimum measured activity that indicates a positive detection of the radionuclide in the sample with less than a 5 percent probability of a false positive detection. Sample-specific critical levels are used for radiochemical measurements because the critical level is sensitive to sample size and sample yield during analytical processing and is dependent on instrument background, on counting times for the sample and background, and on the characteristics of the instrument being used and the nuclide being measured. An ssL $\mathrm{L}_{\mathrm{C}}$ is calculated for each sample, and the measured activity in the sample is compared to the $\mathrm{ssL}_{\mathrm{C}}$ associated with that sample. Measured activities less than the $\mathrm{ssL}_{\mathrm{C}}$ are reported as non-detections with a dash (-) in the data tables.

The analytical uncertainties associated with measurement of activities also are sensitive to sample-specific parameters, including sample size, sample yield during analytical processing, and time elapsed between sample collection and various steps in the analytical procedure, as well as parameters associated with the instrumentation. Therefore, tritium activities are reported as plus or minus $( \pm)$ sample-specific combined standard uncertainties (CSU) (table 12). The CSU is reported at the 68 percent confidence level (1-sigma). Tritium reporting levels were expressed as MRLs before August 2007, and as $\mathrm{ssL}_{\mathrm{C}} \mathrm{s}$ after August 2007. Both reporting level types were used during August 2007.

Results for some organic and inorganic constituents are presented using SRLs derived from assessment of data from QC samples associated with groundwater samples collected as part of the GAMA-PBP (Olsen and others, 2010; Fram and others, 2012). SRLs are equal to or greater than the reporting levels used by the laboratory. Detections reported by the laboratory with concentrations less than SRLs may have significant contamination bias. Such detections are expressed in the results tables as equal to or less than $(\leq)$ the reported concentration.

\section{Notation}

Stable isotopic compositions of hydrogen, oxygen, and carbon are reported as relative isotope ratios in units of per mil using the standard delta notation (Coplen and others, 2002):

$$
\delta^{i} E=\left[\frac{R_{\text {sample }}}{R_{\text {reference }}}-1\right] \times 1,000 \text { per mil }
$$

where $\quad i \quad$ is the atomic mass of the heavier isotope of

$$
\begin{gathered}
E \quad \text { is the element (H for hydrogen, O for oxygen, } \\
\text { C for carbon), } \\
R_{\text {sample }} \quad \text { is the ratio of the abundance of the heavier } \\
\text { isotope of the element }\left({ }^{2} \mathrm{H},{ }^{18} \mathrm{O},{ }^{13} \mathrm{C}\right) \text { to the } \\
\text { lighter isotope of the element }\left({ }^{1} \mathrm{H},{ }^{16} \mathrm{O},{ }^{12} \mathrm{C}\right) \\
\text { in the sample, and }
\end{gathered}
$$

The reference material for oxygen and hydrogen is Vienna Standard Mean Ocean Water (VSMOW), which is assigned $\delta^{18} \mathrm{O}$ and $\delta^{2} \mathrm{H}$ values of 0 per mil (note that $\delta^{2} \mathrm{H}$ is sometimes written as $\delta \mathrm{D}$ because the common name of the heavier isotope of hydrogen, hydrogen-2, is deuterium) (Coplen and others, 2002). The reference material for carbon is Vienna Pee Dee Belemnite (VPDB), which is assigned a $\delta^{13} \mathrm{C}$ value of 0 per mil (Coplen and others, 2002). Positive values indicate enrichment of the heavier isotope, and negative values indicate depletion of the heavier isotope, compared to the ratios observed in the standard reference material.

\section{Constituents on Multiple Analytical Schedules}

Fourteen constituents targeted in this study were measured by more than one analytical method or by more than one laboratory (table A2). Preferred analytical methods are indicated in the constituent tables (tables 3A, 3B, 3D, $3 \mathrm{E}, 3 \mathrm{G}, 3 \mathrm{H}$ ) and the results tables (tables $4,5,6,7,10,11$ ). The preferred methods were generally selected on the basis of better performance or sensitivity for the constituent but, in all cases, results are given for both methods in the results tables. Six pesticide compounds - atrazine, deethylatrazine, carbaryl, carbofuran, metalaxyl, and tebuthiuron - as well as two VOCs-DBCP and EDB - were analyzed by two different NWQL analytical methods (table A2). An additional VOC$1,2,3-\mathrm{TCP}$ - was analyzed by the NWQL, as well as by an outside laboratory (MWH during initial sampling, and Weck during resampling).

Similarly, total dissolved arsenic and iron concentrations were measured by the NWQL, as well as by the USGS NRP-TML as part of the determination of the oxidationreduction species of these metals. The process, using iron as an example, is as follows: 


$$
\frac{F e(I I I)}{F e(I I)}=\frac{F e(T)-F e(I I)}{F e(I I)}
$$

where $\mathrm{Fe}(\mathrm{T}) \quad$ is the total iron concentration (measured);

$\mathrm{Fe}(\mathrm{II}) \quad$ is the concentration of ferrous iron (measured); and

$\mathrm{Fe}(\mathrm{III})$ is the concentration of ferric iron (calculated). For arsenic, the measured oxidationreduction species is arsenite [As(III)], and the calculated species is arsenate $[\mathrm{As}(\mathrm{V})]$.

The field water-quality indicators - $\mathrm{pH}$ and specific conductance - were measured in the field and at the NWQL during the resampling period and for some samples collected from trend wells during initial sampling. During initial sampling, field measurements of alkalinity were often performed on samples for which alkalinity was also measured by the NWQL. The field measurements are the preferred method for these three water-quality indicators. However, field and laboratory measurements are reported in table 4. Field values are preferred because field conditions are considered more representative of groundwater conditions (Hem, 1985).

Additionally, perchlorate was measured by two laboratories (MWH and Weck) for nine samples collected from trend wells in the San Diego Drainages and North San Francisco Bay study units (table 7). Prior to August 2007, perchlorate analysis for GAMA-PBP was performed on unfiltered samples by MWH. After December 2007, perchlorate analysis was performed on filtered samples by Weck. From August to December 2007, perchlorate analyses were performed by both laboratories on selected samples in an effort to determine the comparability of results from the two laboratories.

\section{Quality-Control Methods and Results}

The purpose of QC samples is to identify which data best represent environmental conditions and which may have been affected by contamination or bias during sample collection, processing, storage, transportation, and (or) laboratory analysis. Four types of QC measurements were evaluated in this study: (1) blank samples were collected to assess positive bias as a result of contamination during sample handling or analysis, (2) replicate samples were collected to assess variability, (3) matrix-spike tests were done for organic constituents to assess positive or negative bias, and (4) surrogate compounds were added to samples analyzed for organic constituents to assess potential matrix effects from the chemical composition of each groundwater sample, as well as to assess potential bias of laboratory analytical methods.

\section{Blank Samples}

The primary purposes of collecting blanks are to evaluate the magnitude of potential contamination of samples with compounds of interest during sample handling or analysis and to identify and mitigate the sources of sample contamination.

\section{Blank Collection and Analysis}

Blanks were collected using blank water certified by the NWQL to contain less than the reporting levels for selected constituents investigated in the study (National Water Quality Laboratory, written commun., 2012). Nitrogen-purged, organic-free blank water was used for blanks of organic constituents, and inorganic-free blank water was used for blanks of inorganic constituents. Two types of blanks (field and source-solution) were collected during resampling in 2007-2008 (table A3).

Field blanks were collected to assess potential contamination of samples during collection, processing, transport, and analysis. To collect field blanks at the sampling sites, blank water was either pumped or poured through the sampling equipment (fittings and tubing) used to collect groundwater samples, then processed and transported using the same protocols used for the groundwater samples. Field blanks were analyzed for VOCs (11 field blanks), pesticides and pesticide degradates (10), perchlorate (9), 1,2,3-TCP (7), NDMA (2), trace elements (11), nutrients (11), major and minor ions (11), silica (11), TDS (11), total arsenic and iron (1), and arsenic and iron species (1).

Source-solution blanks are collected at the beginning of a study, or when using a new lot of blank water, to assess potential contamination of samples during transport and analysis and potential contamination of the certified blank water obtained from the NWQL. Source-solution blanks were collected in the field inside the mobile laboratory by pouring blank water directly into sample containers. These samples were then preserved, stored, shipped, and analyzed in the same manner as the groundwater samples. Source-solution blanks were analyzed for VOCs (4 source solution blanks), perchlorate (5), 1,2,3-TCP (2), trace elements (2), nutrients (1), major and minor ions (2), silica (2), and TDS (2).

Blanks were not collected for isotopic ratios. Isotopic ratios of hydrogen, oxygen, and carbon are an intrinsic property of any of these elements; therefore, the concept of a blank does not apply to these ratios. In addition, blanks were not collected for tritium. Tritium is in the atmosphere and would dissolve into any solution used in collecting a blank, making it impractical to collect a blank for tritium. 


\section{Blank Sample Results}

Blanks were analyzed for 272 constituents. Field blanks were not analyzed for the four field water-quality indicators (dissolved oxygen, water temperature, $\mathrm{pH}$, and specific conductance), the five laboratory water-quality indicators (specific conductance, $\mathrm{pH}$, alkalinity, bicarbonate, and carbonate), the four species of arsenic and iron, or the five isotopic tracers (two stable isotopes of water, tritium, and two isotopes of carbon). Of the 272 constituents for which blanks were performed, 12 constituents were detected in at least 1 field blank (table A3). For three trace elements (copper, lead, and nickel), a nutrient (nitrite), a major ion (calcium), and silica, the detected concentrations in blanks were less than the applicable reporting limits (LRL, LT-MDL, MDL, MRL, or SRL); thus, no change in reporting limits was applied to results for these constituents due to detections in blanks. An additional trace element, chromium, had a measured concentration in a blank of $0.89 \mu \mathrm{g} / \mathrm{L}$, which is greater than the SRL of $0.42 \mu \mathrm{g} / \mathrm{L}$ established by Olsen and others (2010). The detection was considered isolated, however, because the chromium concentration in the associated groundwater sample was less than $0.42 \mu \mathrm{g} / \mathrm{L}$. Therefore, the SRL of $0.42 \mu \mathrm{g} / \mathrm{L}$ for chromium was used for this study.

Similar to chromium, isolated low-level detections of acetone and chloroform in blanks were not accompanied by detections in their associated groundwater samples; therefore, acetone and chloroform results are reported here in accordance with the LRLs in effect for acetone and chloroform at the time of analysis (table A3). For the single field blank detection of 1,2,3-TCP, the source-solution blank and the groundwater sample associated with the field blank also had detections at concentrations similar to the detection in the field blank. Therefore, the detection of 1,2,3-TCP in the Southern Sacramento Valley study unit well YOL-01 during resampling may be attributed to inadvertent sample contamination affecting all three samples. Similar to copper, lead, and nickel, the detected concentrations in blanks for two VOCs1,2,4-trimethylbenzene and toluene-were all less than the SRLs established by Fram and others (2012); thus, these SRLs were applied to results for these constituents. Detections of constituents at concentrations less than SRLs were coded as less than or equal to $(\leq)$ their measured concentrations in the samples and are counted as non-detections for the purpose of calculating detection frequencies for this report.

All but 2 of the 12 constituents detected in field blanks collected during resampling of trend wells in 2007-2008 (nitrite and 1,2,3-TCP) were also detected in at least one field blank collected during initial sampling of the 7 resampled study units. An additional 45 constituents were detected in at least one field blank collected during the initial sampling of these study units, which occurred during 2004-2005, and decisions to qualify results from these sampling efforts were made during preparation of the pertinent data series reports (Wright and others, 2005; Bennett and others, 2006; Kulongoski and others, 2006; Kulongoski and Belitz, 2007;
Burton and Belitz, 2008; Dawson and others, 2008; Land and Belitz, 2008). In some cases, blank sample data qualification done after initial sampling has been superceded by GAMA policy in effect since the application of study reporting levels (Olsen and others, 2010; Fram and others, 2012).

\section{Replicate Samples}

Sequential replicate samples were collected to assess the precision of the water-quality data. Estimates of data precision are needed to assess whether differences between concentrations in samples are due to differences in groundwater quality (for example, spatial or temporal trends) or to variability that may result from collecting, processing, and analyzing the samples.

\section{Replicate Collection and Analysis}

The acceptable limits for differences in measured concentrations between replicate paired samples were determined using one of two criteria. The criterion selection depended on the magnitude of the measured concentration of a constituent relative to its reporting level. If the concentration of a constituent was less than 5 times its reporting level, a standard deviation (SD) for the sample pair of less than half the reporting level was considered acceptable. If the concentration of a constituent was greater than or equal to 5 times its reporting level, a relative standard deviation (RSD) of less than 10 percent was considered acceptable. The RSD is defined as the SD divided by the mean concentration for each replicate pair of samples expressed as a percentage. An RSD of less than 10 percent was also used for isotopes, with the exception of tritium. For tritium, the activity in the paired samples could differ by no more than the combined standard uncertainty reported for the samples in order to be acceptable.

When one or both values of a replicate pair were reported as non-detections, variability was evaluated in the following manner. If both values were reported as non-detections, the variability was considered acceptable because the results are perfectly consistent. If one value was reported as a non-detection $(<\mathrm{RL})$ and the other value was reported as a detection less than the RL, the variability was considered acceptable because these two values, while not perfectly consistent, are in agreement as being less than the RL. If one value was reported as a non-detection and the other value was reported as a detection greater than or equal to the RL, the variability for the pair was considered unacceptable.

\section{Replicate Results}

Tables A4A-A4B summarize the results of replicate analyses for constituents in groundwater samples collected during resampling for trends and that were detected in at least one of the samples of a replicate pair. One or 2 replicates for 10 constituents indicated unacceptable variability, including 2 of 5 replicates for perchlorate (method performed on filtered 
samples); 2 of 6 replicates for aluminum, nickel, and zinc; 1 of 6 replicates for chromium, copper, and iron; 1 of 5 replicates for 1,2,3-TCP and pmc; and 1 of 3 replicates for arsenite [As(III)]. Environmental detections were not modified on the basis of the replicate analyses.

\section{Matrix-Spike Samples}

Addition of a known concentration of a constituent (spike) to a replicate environmental sample enables the analyzing laboratory to determine the effect of the matrix, in this case groundwater, on the analytical technique used to measure the constituent. The known compounds added in matrix spikes are the same as those being analyzed in the environmental samples. This enables an analysis of matrix interferences on a compound-by-compound basis. For this study, matrix spikes were added by the laboratories performing the analysis rather than in the field. Low matrix-spike recovery may indicate that the compound might not have been detected in some samples if it were present at very low concentrations. Low and high matrix-spike recoveries may be a potential concern if the concentration of a compound in a groundwater sample is close to the health-based benchmark; a low recovery could result in a falsely measured concentration less than the health-based benchmark, whereas a high recovery could result in a falsely measured concentration greater than the healthbased benchmark.

The GAMA-PBP defined the data-quality objective range for acceptable median matrix-spike recoveries as 70-130 percent. Only constituents with median matrixspike recoveries outside of this range were flagged as having unacceptable recoveries. For some constituents, an acceptable range of 70-130 percent for median matrix-spike recovery was more restrictive than the acceptable control limits for laboratory set-spike recoveries. Laboratory set spikes are aliquots of laboratory blank water to which the same spike solution used for the matrix spikes has been added. One set spike is analyzed with each set of samples. Acceptable control limits for set spikes are defined relative to the long-term variability in recovery. For example, for many NWQL analyses, acceptable set-spike recovery is within \pm 3 F-pseudosigma of the median recovery for at least 30 set spikes (Conner and others, 1998). The F-psuedosigma is calculated by dividing the fourth-spread (analogous to interquartile range) by 1.349 ; therefore, the smaller the F-pseudosigma, the more precise the determinations (Hoaglin, 1983). Laboratory matrix spikes were performed for 231 out of the 232 organic constituents sampled in this study, including VOCs, pesticides (including polar pesticides), and pesticide degradates because the analytical methods for these constituents may be susceptible to matrix interference. NDMA was sampled for in only two of the study units, and no matrix spikes were performed for NDMA.

\section{Matrix-Spike Recoveries}

Tables A5A-A5E present a summary of matrix-spike recoveries of organic constituents analyzed in trend samples. Median matrix-spike recoveries were within acceptable limits for all VOCs (tables A5A, A5B, A5E). However, median matrix-spike recoveries for 50 of the 143 pesticide compounds were lower than the acceptable limits (tables A5C, A5D), which may indicate that these constituents might not have been detected in some samples even if they were present in the samples. In addition, median recoveries for seven pesticide compounds were higher than acceptable limits, but despite this indication of positive analytical bias, only one of these seven compounds (tebuthiuron) was detected in unspiked groundwater samples during this study.

\section{Surrogate Compounds}

Surrogate compounds are added to groundwater samples in the laboratory prior to analysis to evaluate the recovery of similar constituents. Surrogate compounds were added in the laboratory to all groundwater and QC samples that were analyzed by the NWQL for VOCs and pesticides and pesticide degradates. Surrogates are used to identify general problems that may arise during laboratory sample analysis that could affect the analysis results for all compounds in that sample. Potential problems include matrix interferences (such as high levels of dissolved organic carbon) that can produce a positive or negative bias or incomplete laboratory recovery (possibly because of improper maintenance and calibration of analytical equipment) that produces a negative bias. A 70 to 130 percent recovery of surrogates, in general, is considered acceptable; values outside this range indicate possible problems with the processing and analysis of samples (Connor and others, 1998; Sandstrom and others, 2001) or groundwater matrix interference.

\section{Surrogate recoveries}

Median recoveries were within the acceptable range for all surrogates added to samples for the analyses of VOCs and pesticide compounds (table A6). However, all of the surrogates had recoveries that fell outside the acceptable ranges for samples from individual wells on a few occasions. Only rarely did this occur in samples from the same well for both sampling periods. Therefore, it is unlikely that groundwater matrix interferences caused the recoveries to be outside of the acceptable ranges in most cases. 


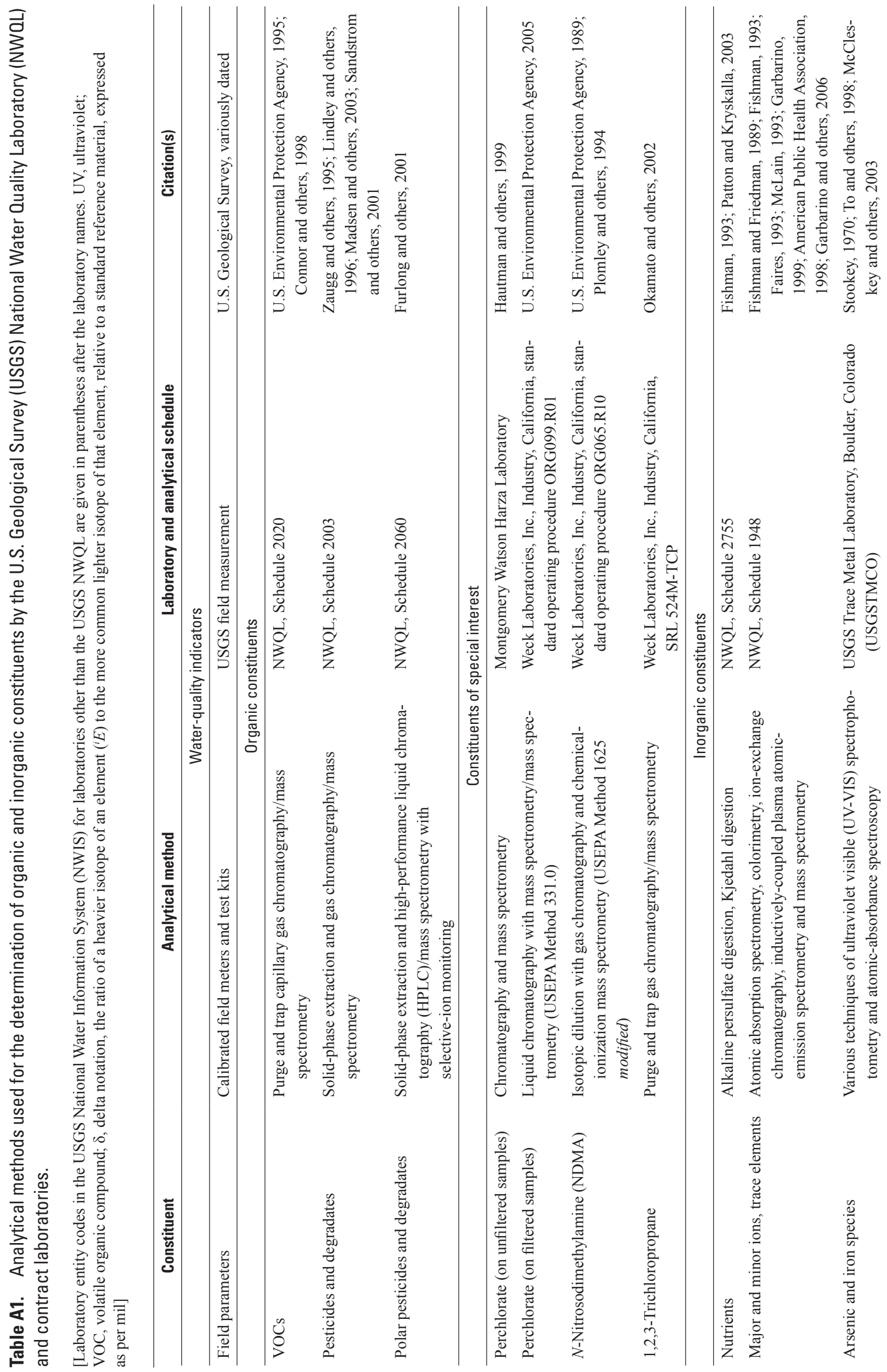




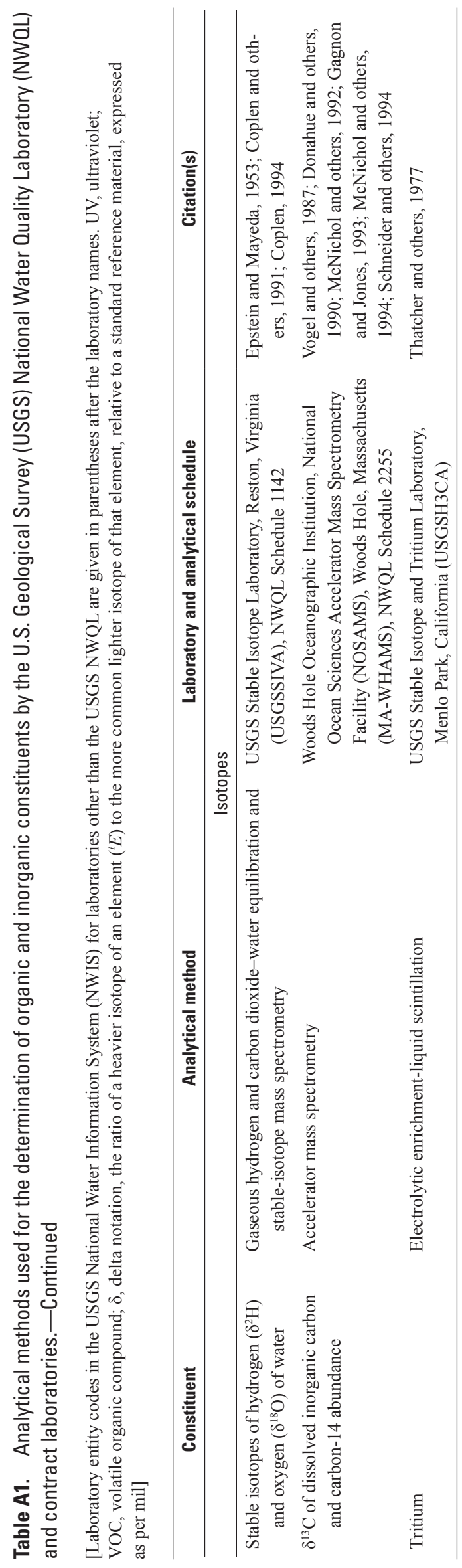


Table A2. Preferred analytical methods or laboratories for selected constituents collected during resampling for trends in the Groundwater Ambient Monitoring and Assessment (GAMA) Priority Basin Project, California, September 2007 to November 2008.

[Preferred analytical schedules are generally the methods of analysis with the greatest accuracy and precision out of the ones used for the constituent in question. USGS National Water Quality Laboratory (NWQL) schedules are referred to by number; Weck, Weck Laboratories, Inc.; MWH, Montgomery Watson Harza Laboratories; TML, USGS Trace Metal Laboratory, Boulder, Colorado; VOC, volatile organic compound; field, analysis performed by field crew upon sample collection]

\begin{tabular}{|c|c|c|c|}
\hline Constituent & $\begin{array}{l}\text { Primary constituent } \\
\text { classification }\end{array}$ & $\begin{array}{c}\text { Preferred } \\
\text { analytical method }{ }^{1}\end{array}$ & $\begin{array}{c}\text { Secondary } \\
\text { analytical method }\end{array}$ \\
\hline \multicolumn{4}{|c|}{ Duplicate analyses performed by two different analytical schedules at the NWOL } \\
\hline Atrazine & Pesticide & $2003^{\mathrm{a}, \mathrm{b}, \mathrm{d}, \mathrm{e}, \mathrm{f}}$ or $2032^{\mathrm{c}}$ or $2033^{\mathrm{g}}$ & $2060^{\mathrm{b}, \mathrm{d}, \mathrm{e}}$ \\
\hline Deethylatrazine (2-Chloro-4-isopropylamino-6-amino-s-triazine) & Pesticide degradate & $2003^{\mathrm{a}, \mathrm{b}, \mathrm{d}, \mathrm{e}, \mathrm{f}}$ or $2032^{\mathrm{c}}$ or $2033^{\mathrm{g}}$ & $2060^{\mathrm{b}, \mathrm{d}, \mathrm{e}}$ \\
\hline Carbaryl & Pesticide & $2003^{\mathrm{a}, \mathrm{b}, \mathrm{d}, \mathrm{e}, \mathrm{f}}$ or $2032^{\mathrm{c}}$ or $2033^{\mathrm{g}}$ & $2060^{\text {b,d,e }}$ \\
\hline Carbofuran & Pesticide & $2032^{\mathrm{c}}$ or $2033^{\mathrm{g}}$ & $2060^{\text {b,d,e }}$ \\
\hline Metalaxyl & Pesticide & $2003^{\mathrm{a}, \mathrm{b}, \mathrm{d}, \mathrm{e}, \mathrm{f}}$ or $2032^{\mathrm{c}}$ or $2033^{\mathrm{g}}$ & $2060^{\text {b,d,e }}$ \\
\hline 1,2-Dibromo-3-chloropropane (DBCP) & VOC, fumigant & $1306^{\mathrm{c}, \mathrm{g}}$ & $2020^{\text {a,b,c,c,e,f,g }}$ \\
\hline 1,2-Dibromoethane (EDB) & VOC, fumigant & $1306^{\mathrm{cog}}$ & 2020 a,b,c,d,e,f,g \\
\hline \multicolumn{4}{|c|}{ Duplicate analyses performed by two different laboratories (or by USGS field personnel and NWOL) } \\
\hline $\mathrm{pH}$ & Water-quality indicator ${ }^{2}$ & field $^{\text {a,b,c,d,e,f,g }}$ & $1948^{\text {a,ble,c,def, }, \mathrm{g}}$ \\
\hline Arsenic (total) & Trace element & $1948^{\text {a,b,c,c,d,ef,g }}$ & $\mathrm{TML}^{\mathrm{b}, \mathrm{e}}$ \\
\hline Iron (total) & Trace element & $1948^{\text {a,b,c,c,e,f,g, }}$ & $\mathrm{TML}^{\mathrm{b}, \mathrm{e}}$ \\
\hline
\end{tabular}

${ }^{1}$ NWQL SC 2032 and 2033 use the same analytical method as NWQL SC 2003, but analyze for additional compounds.

${ }^{2}$ An additional water-quality indicator, alkalinity, was measured both in the field and by NWQL during initial sampling, but was only measured by NWQL during resampling.

a Analysis used in the San Diego Drainages study unit during resampling for trends.

${ }^{\mathrm{b}}$ Analysis used in the North San Francisco Bay study unit during resampling for trends.

${ }^{c}$ Analysis used in the Northern San Joaquin Basin study unit during resampling for trends.

${ }^{\mathrm{d}}$ Analysis used in the Southern Sacramento Valley study unit during resampling for trends.

${ }^{\mathrm{e}}$ Analysis used in the San Fernando-San Gabriel study unit during resampling for trends.

${ }^{\mathrm{f}}$ Analysis used in the Monterey Bay and Salinas Valley Basins study unit during resampling for trends.

${ }^{\mathrm{g}}$ Analysis used in the Southeast San Joaquin Valley study unit during resampling for trends. 
Table A3. Constituents detected in blanks collected during resampling of the first seven Groundwater Ambient Monitoring and Assessment (GAMA) Priority Basin Project study units and constituents for which study reporting levels were established by the GAMA Program.

[E, estimated or having a high degree of uncertainty; LRL, laboratory reporting level; mg/L, milligrams per liter; $\mu \mathrm{g} / \mathrm{L}$, micrograms per liter; nv, no value in category; SRL, study reporting level; <, less than or equal to; - , not detected]

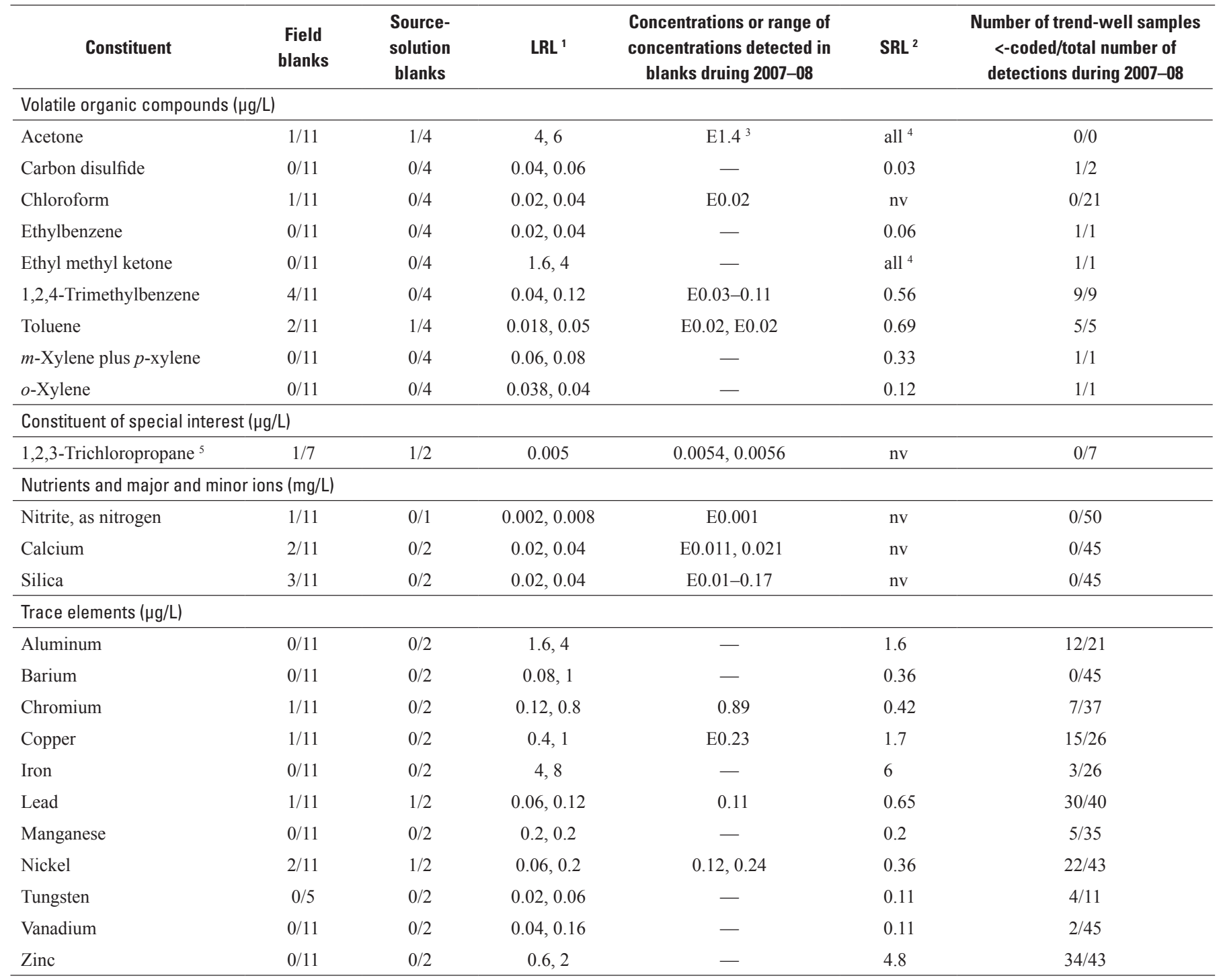

${ }^{1}$ Minimum and maximum LRLs used during study period, or only LRL used during study period.

${ }^{2}$ SRLs for trace elements from Olsen and others (2010) and SRLs for volatile organic compounds from Fram and others (2012).

${ }^{3}$ The detected concentration was less than the LT-MDL for this constituent. This result in a groundwater sample would have counted as a non-detection.

${ }^{4}$ Based on findings by Fram and others (2012), all detections of this compound are reported as "not analyzed."

${ }^{5}$ Field blanks performed for low-level analyses of 1,2,3-trichloropropane were analyzed by Weck Laboratories, Inc. 


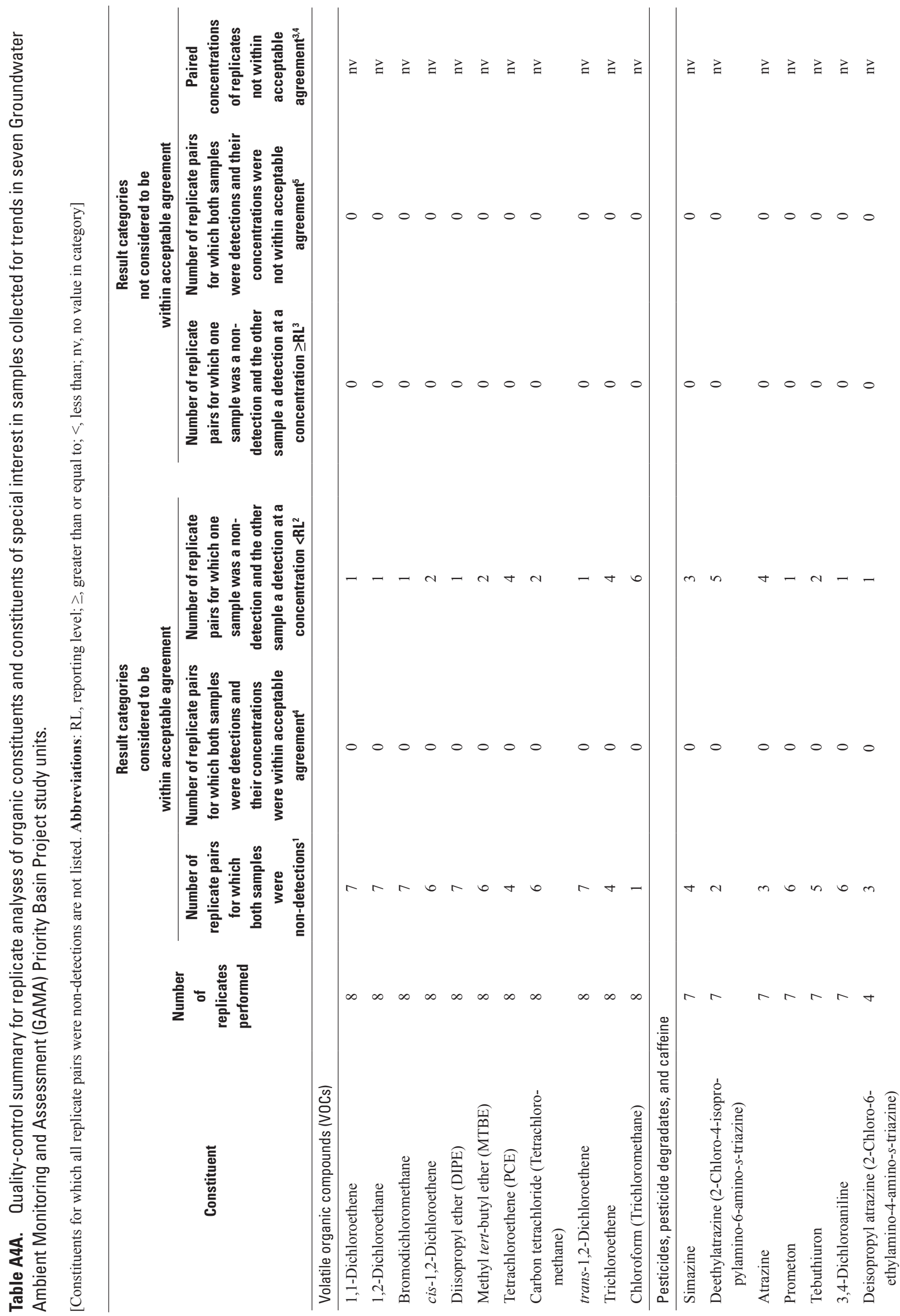




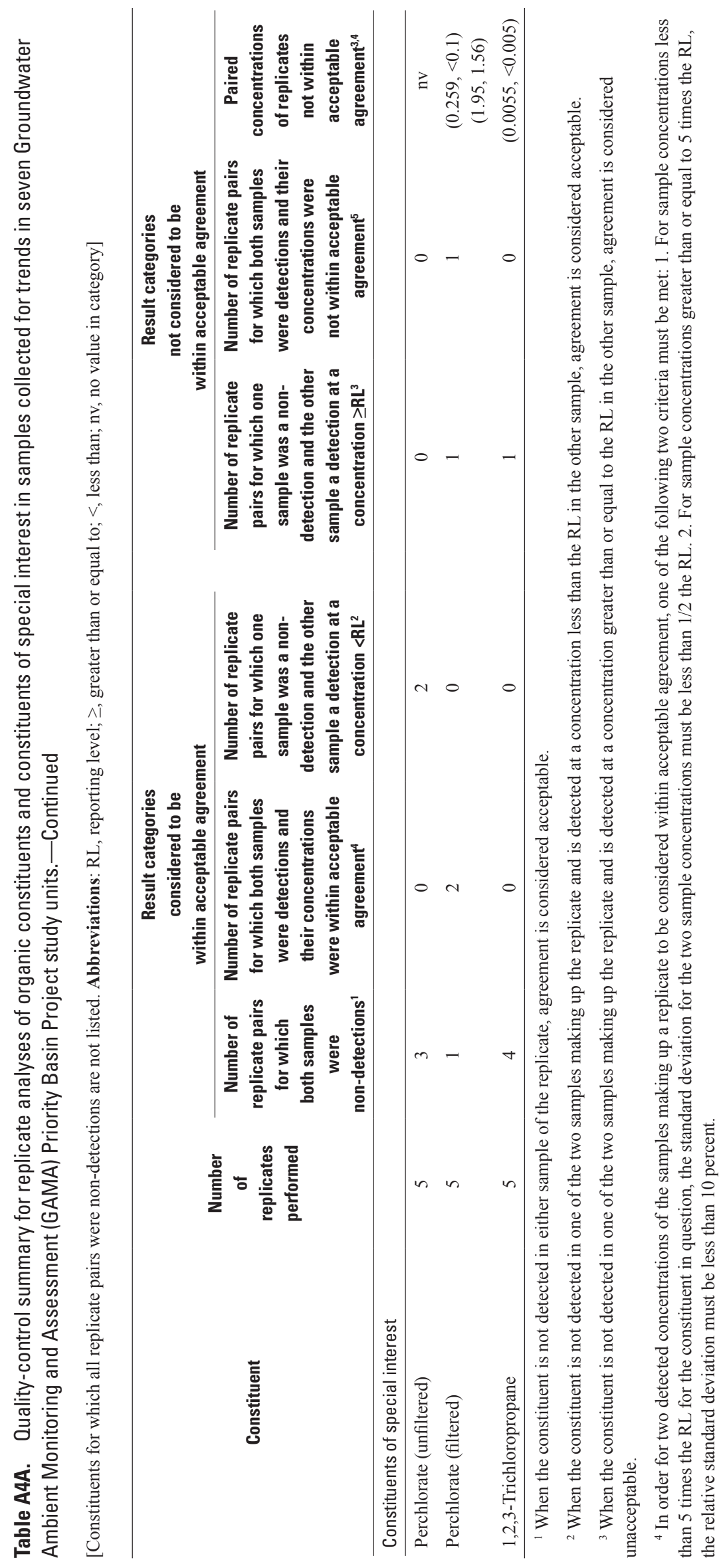




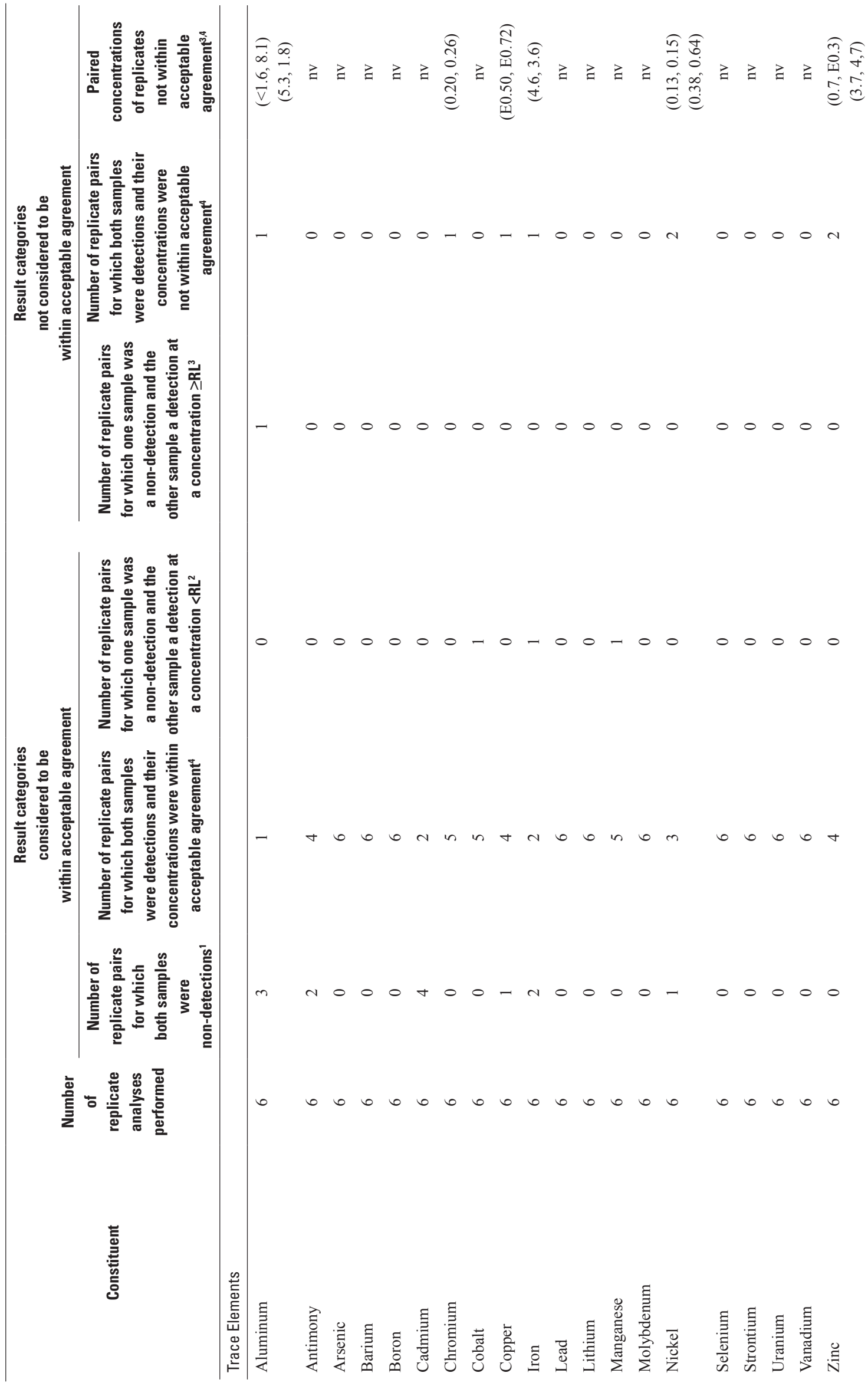




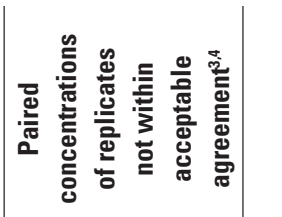

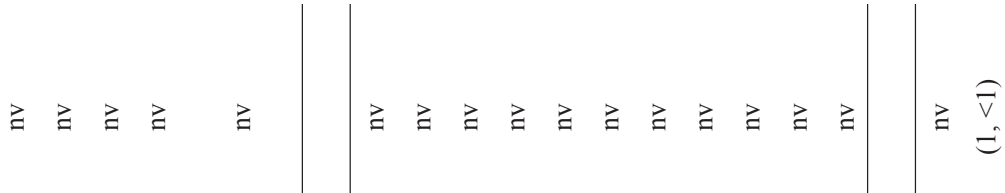

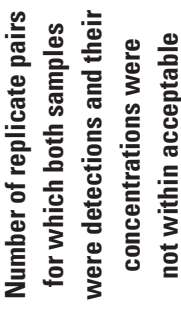

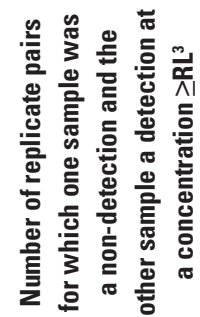

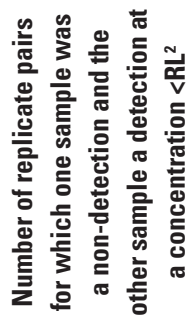

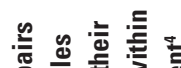

흘

完言言

흔 苞

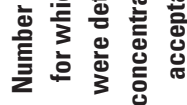

$00000 \quad 000000000000$

$00000 \quad 000000000000-1$

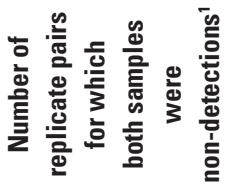

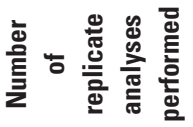

온 는 은

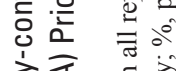

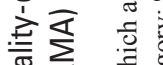

䒚 迹

氹

동.

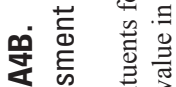

舟

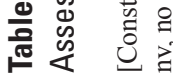

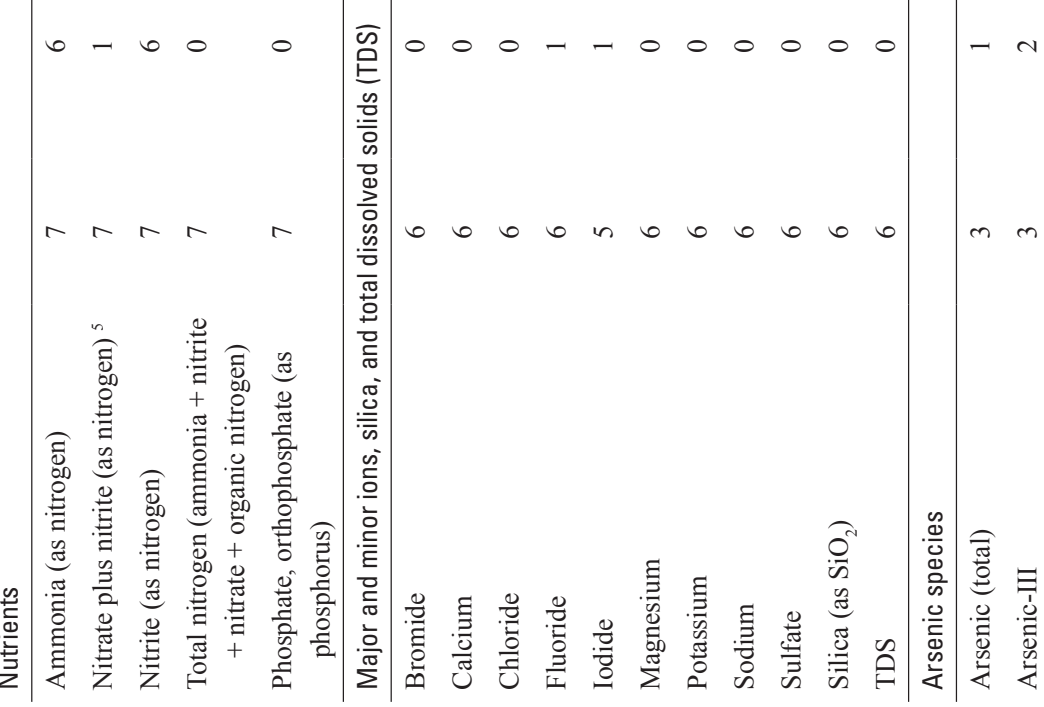




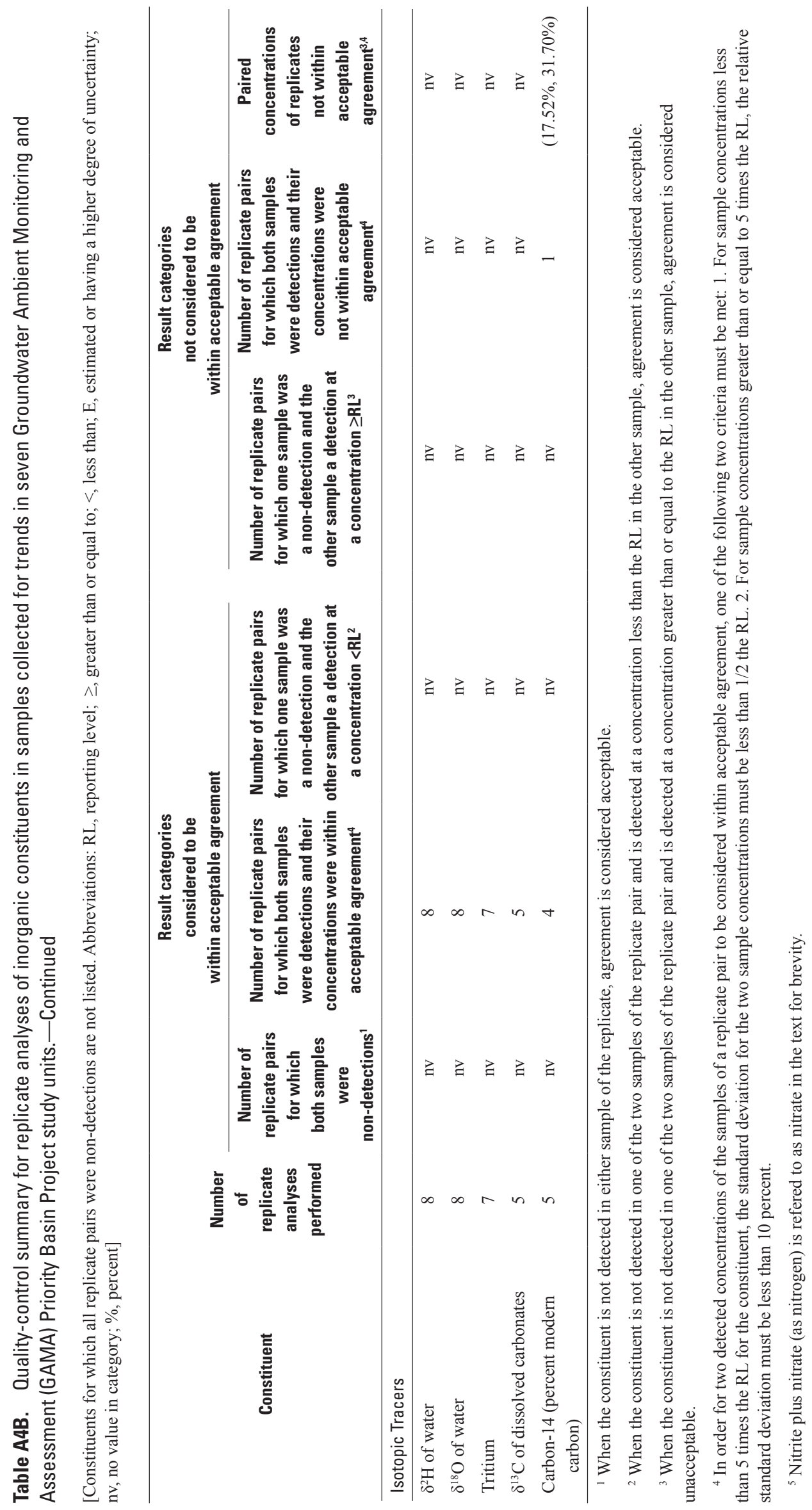


Table A5A. Quality-control summary for matrix-spike recoveries of volatile organic compounds (VOCs) in spiked samples collected for trends in seven Groundwater Ambient Monitoring and Assessment (GAMA) Priority Basin Project study units.

[Acceptable recovery range is between 70 and 130 percent]

\begin{tabular}{|c|c|c|c|c|}
\hline Constituent & $\begin{array}{c}\text { Number of } \\
\text { spike samples }\end{array}$ & $\begin{array}{l}\text { Minimum recovery } \\
\text { (percent) }\end{array}$ & $\begin{array}{l}\text { Maximum recovery } \\
\text { (percent) }\end{array}$ & $\begin{array}{l}\text { Median recovery } \\
\text { (percent) }\end{array}$ \\
\hline Acetone & 7 & 97 & 133 & 107 \\
\hline tert-Amyl methyl ether (TAME) & 7 & 94 & 121 & 106 \\
\hline Benzene & 7 & 96 & 112 & 103 \\
\hline Bromobenzene & 7 & 94 & 128 & 101 \\
\hline Bromodichloromethane $^{1}$ & 7 & 98 & 118 & 103 \\
\hline Bromoform (Tribromomethane) ${ }^{1}$ & 7 & 95 & 123 & 103 \\
\hline Bromomethane (Methyl bromide) & 7 & 89 & 145 & 111 \\
\hline$n$-Butylbenzene & 7 & 80 & 108 & 90 \\
\hline sec-Butylbenzene & 7 & 92 & 122 & 99 \\
\hline Chlorobenzene & 7 & 95 & 117 & 101 \\
\hline Chloroethane & 7 & 70 & 127 & 109 \\
\hline Chloroform (Trichloromethane) ${ }^{1}$ & 7 & 84 & 124 & 113 \\
\hline Chloromethane & 7 & 82 & 114 & 95 \\
\hline 3-Chloropropene & 7 & 90 & 119 & 110 \\
\hline 2-Chlorotoluene & 7 & 95 & 128 & 110 \\
\hline 4-Chlorotoluene & 7 & 96 & 119 & 104 \\
\hline Dibromochloromethane $^{1}$ & 7 & 98 & 109 & 100 \\
\hline 1,2-Dibromo-3-chloropropane (DBCP) ${ }^{1}$ & 7 & 87 & 113 & 101 \\
\hline Dichlorodifluoromethane (CFC-12) ${ }^{1}$ & 7 & 61 & 112 & 81 \\
\hline 1,1-Dichloroethane $(1,1-\mathrm{DCA})^{1}$ & 7 & 93 & 119 & 108 \\
\hline 1,2-Dichloroethane $(1,2 \text {-DCA })^{1}$ & 7 & 96 & 122 & 106 \\
\hline 1,1-Dichloroethene (1,1-DCE) ${ }^{1}$ & 7 & 92 & 114 & 99 \\
\hline$c i s-1,2$-Dichloroethene $(c i s-1,2-\mathrm{DCE})^{1}$ & 7 & 90 & 118 & 107 \\
\hline trans-1,2-Dichloroethene (trans-1,2-DCE) ${ }^{1}$ & 7 & 92 & 114 & 109 \\
\hline 1,2-Dichloropropane & 7 & 91 & 114 & 103 \\
\hline 1,3-Dichloropropane & 7 & 92 & 118 & 107 \\
\hline 2,2-Dichloropropane & 7 & 74 & 104 & 100 \\
\hline 1,1-Dichloropropene & 7 & 92 & 105 & 101 \\
\hline cis-1,3-Dichloropropene & 7 & 87 & 103 & 98 \\
\hline trans-1,3-Dichloropropene & 7 & 89 & 102 & 97 \\
\hline Diethyl ether & 7 & 88 & 121 & 116 \\
\hline Diisopropyl ether (DIPE) ${ }^{1}$ & 7 & 90 & 120 & 112 \\
\hline
\end{tabular}


Table A5A. Quality-control summary for matrix-spike recoveries of volatile organic compounds (VOCs) in spiked samples collected for trends in seven Groundwater Ambient Monitoring and Assessment (GAMA) Priority Basin Project study units.-Continued

[Acceptable recovery range is between 70 and 130 percent]

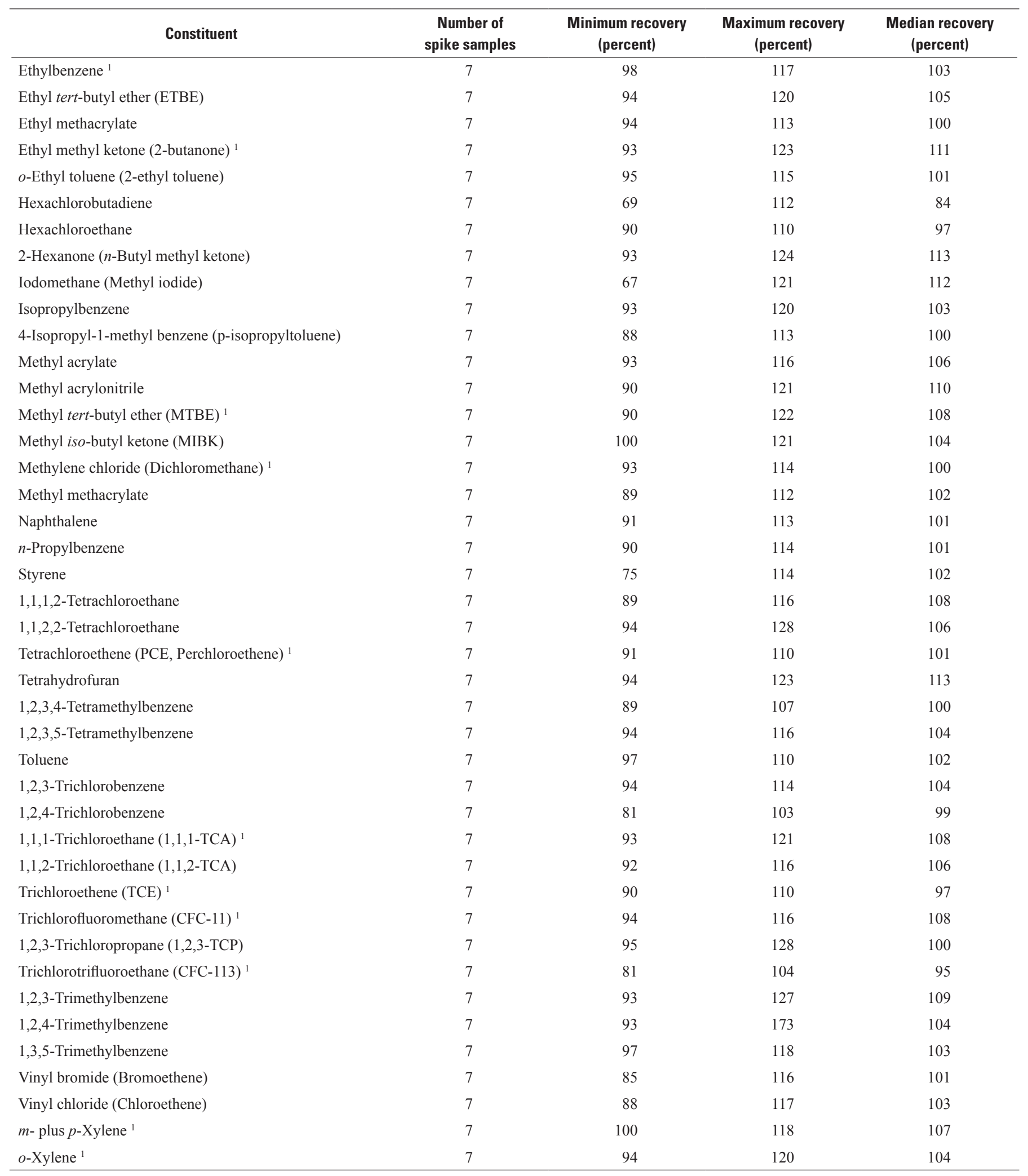

\footnotetext{
${ }^{1}$ Constituent detected in groundwater samples.
} 
Table A5B. Quality-control summary for matrix-spike recoveries of low-level fumigants in spiked samples collected for trends in seven Groundwater Ambient Monitoring and Assessment (GAMA) Priority Basin Project study units.

[Acceptable recovery range is between 70 and 130 percent]

\begin{tabular}{lcccc}
\hline \multicolumn{1}{c}{ Constituent } & $\begin{array}{c}\text { Number of } \\
\text { spike samples }\end{array}$ & $\begin{array}{c}\text { Minimum recovery } \\
\text { (percent) }\end{array}$ & $\begin{array}{c}\text { Maximum recovery } \\
\text { (percent) }\end{array}$ & $\begin{array}{c}\text { Median recovery } \\
\text { (percent) }\end{array}$ \\
\hline 1,2-Dibromo-3-chloropropane (DBCP) ${ }^{1}$ & 2 & 96 & 129 & 112 \\
1,2-Dibromoethane (EDB) & 2 & 90 & 123 & 106 \\
\hline
\end{tabular}

${ }^{1}$ Constituent detected in groundwater samples. 
Table A5C. Quality-control summary for matrix-spike recoveries of pesticides and pesticide degradates (Laboratory Schedules 2003/2032/2033) in spiked samples collected for trends in seven Groundwater Ambient Monitoring and Assessment (GAMA) Priority Basin Project study units.

[Acceptable recovery range is between 70 and 130 percent]

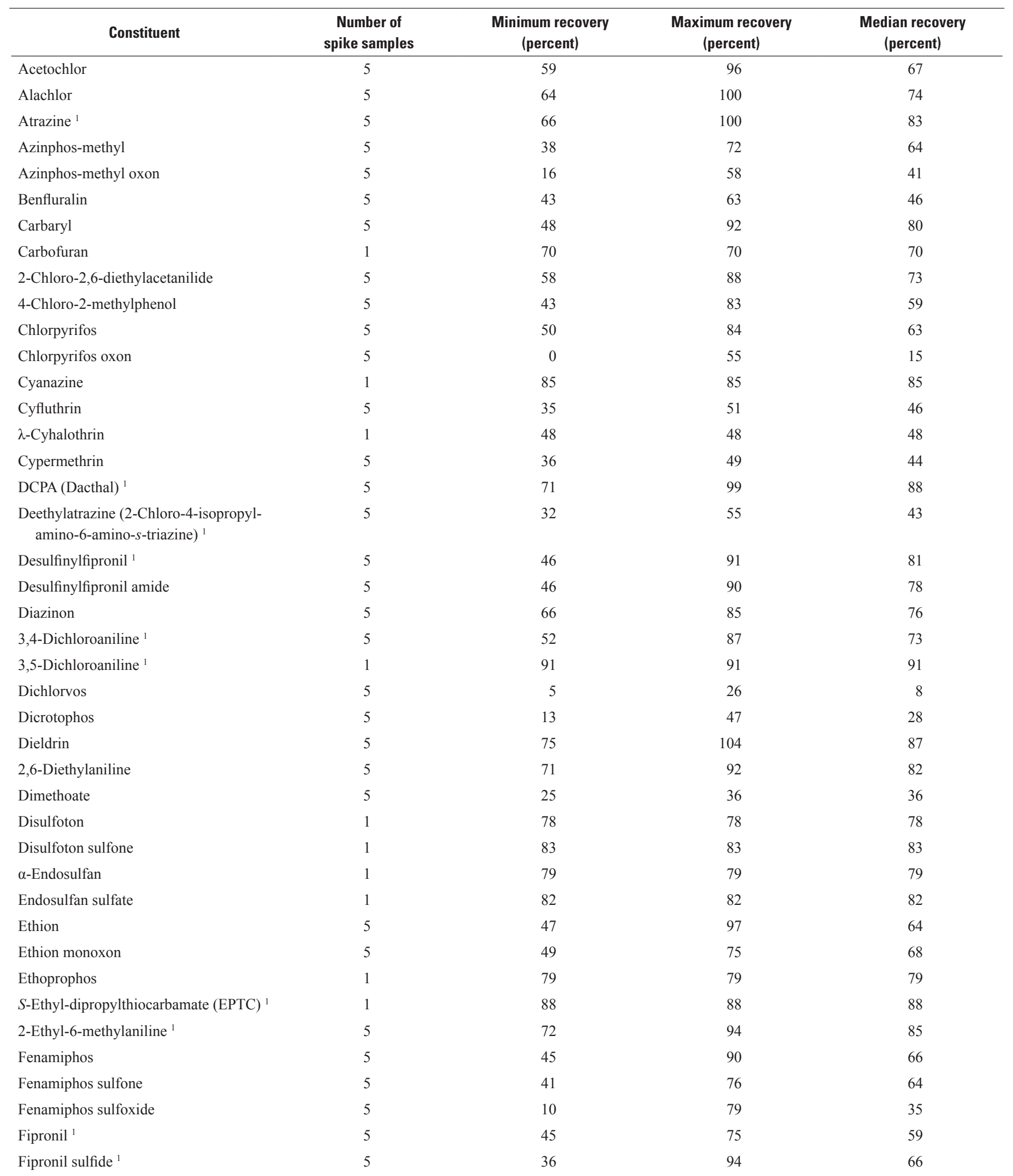


Table A5C. Quality-control summary for matrix-spike recoveries of pesticides and pesticide degradates (Laboratory Schedules 2003/2032/2033) in spiked samples collected for trends in seven Groundwater Ambient Monitoring and Assessment (GAMA) Priority Basin Project study units. - Continued

[Acceptable recovery range is between 70 and 130 percent]

\begin{tabular}{|c|c|c|c|c|}
\hline Constituent & $\begin{array}{c}\text { Number of } \\
\text { spike samples }\end{array}$ & $\begin{array}{l}\text { Minimum recovery } \\
\text { (percent) }\end{array}$ & $\begin{array}{l}\text { Maximum recovery } \\
\text { (percent) }\end{array}$ & $\begin{array}{l}\text { Median recovery } \\
\text { (percent) }\end{array}$ \\
\hline Fipronil sulfone & 5 & 33 & 77 & 54 \\
\hline Hexazinone $^{1}$ & 5 & 36 & 61 & 55 \\
\hline Iprodione & 5 & 36 & 61 & 53 \\
\hline Isofenphos & 5 & 53 & 83 & 69 \\
\hline Malathion & 5 & 52 & 85 & 66 \\
\hline Metalaxyl & 5 & 59 & 85 & 80 \\
\hline Methidathion & 5 & 56 & 99 & 73 \\
\hline Metolachlor & 5 & 60 & 91 & 76 \\
\hline Metribuzin & 5 & 53 & 72 & 60 \\
\hline Oxyfluorfen & 1 & 69 & 69 & 69 \\
\hline Paraoxon-methyl & 5 & 25 & 50 & 35 \\
\hline Parathion-methyl & 5 & 52 & 64 & 62 \\
\hline Pendimethalin & 5 & 57 & 80 & 64 \\
\hline cis-Permethrin & 5 & 34 & 81 & 39 \\
\hline Phorate & 5 & 38 & 69 & 51 \\
\hline Phorate oxon & 5 & 49 & 71 & 67 \\
\hline Phosmet & 5 & 10 & 30 & 26 \\
\hline Phosmet oxon & 5 & 0 & 31 & 9 \\
\hline trans-Propiconazole & 1 & 85 & 85 & 85 \\
\hline Simazine $^{1}$ & 5 & 57 & 101 & 74 \\
\hline Tebuconazole & 1 & 52 & 52 & 52 \\
\hline Tebuthiuron $^{1}$ & 5 & 89 & 210 & 138 \\
\hline Tefluthrin & 1 & 46 & 46 & 46 \\
\hline Terbufos & 5 & 49 & 210 & 75 \\
\hline Terbufos oxon sulfone & 5 & 44 & 75 & 51 \\
\hline Terbuthylazine & 5 & 68 & 94 & 82 \\
\hline Thiobencarb & 1 & 98 & 98 & 98 \\
\hline Tribufos & 5 & 29 & 65 & 51 \\
\hline Trifluralin & 5 & 49 & 68 & 52 \\
\hline
\end{tabular}

\footnotetext{
${ }^{1}$ Constituent detected in groundwater samples.
} 
Table A5D. Quality-control summary for matrix-spike recoveries of polar pesticides, pesticide degradates, and caffeine (Laboratory Schedule 2060) in spiked samples collected for trends in seven Groundwater Ambient Monitoring and Assessment (GAMA) Priority Basin Project study units.

[Acceptable recovery range is between 70 and 130 percent]

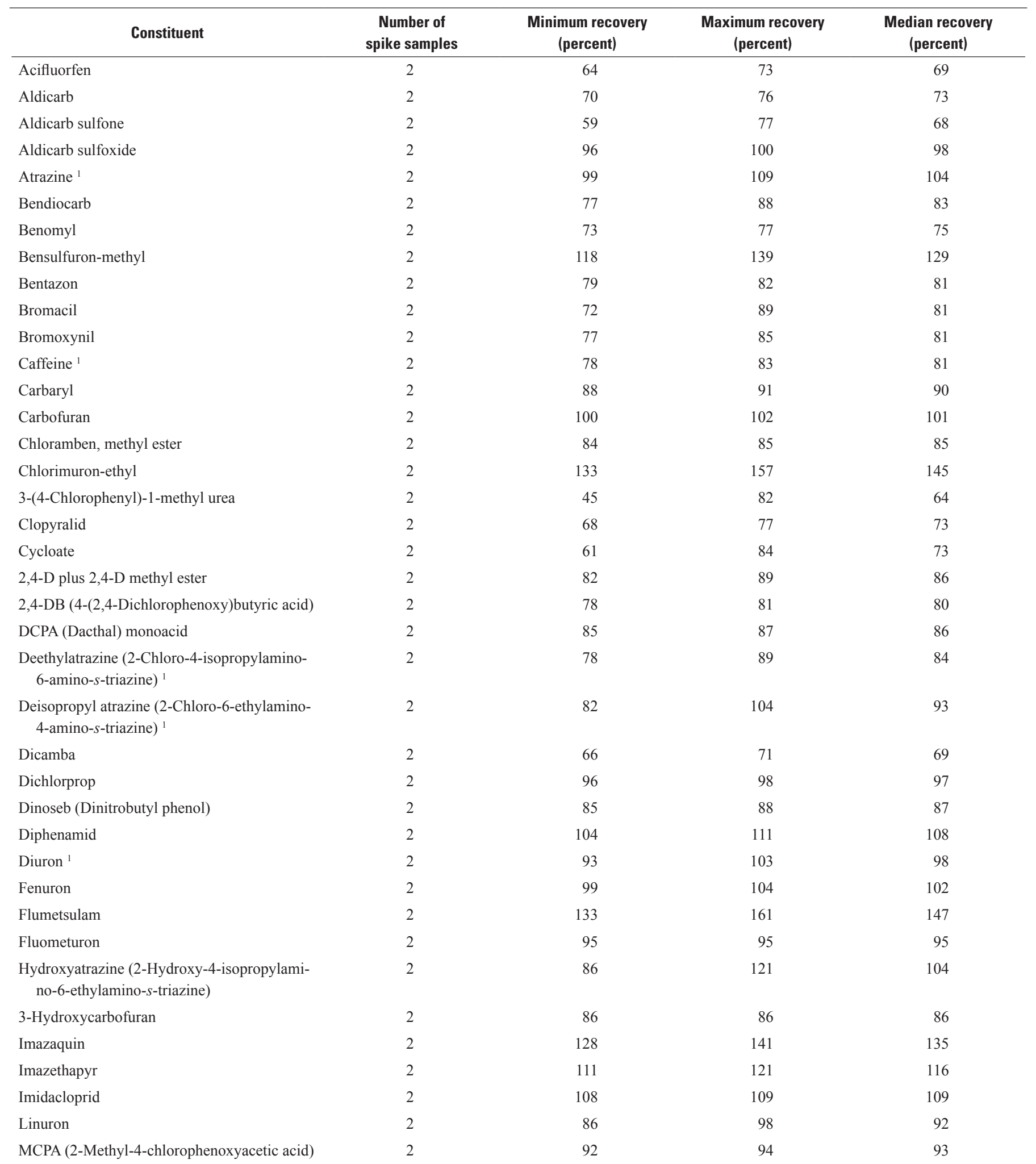


Table A5D. Quality-control summary for matrix-spike recoveries of polar pesticides, pesticide degradates, and caffeine (Laboratory Schedule 2060) in spiked samples collected for trends in seven Groundwater Ambient Monitoring and Assessment (GAMA) Priority Basin Project study units.-Continued

[Acceptable recovery range is between 70 and 130 percent]

\begin{tabular}{|c|c|c|c|c|}
\hline Constituent & $\begin{array}{c}\text { Number of } \\
\text { spike samples }\end{array}$ & $\begin{array}{l}\text { Minimum recovery } \\
\text { (percent) }\end{array}$ & $\begin{array}{l}\text { Maximum recovery } \\
\text { (percent) }\end{array}$ & $\begin{array}{l}\text { Median recovery } \\
\text { (percent) }\end{array}$ \\
\hline $\begin{array}{l}\text { MCPB (4-(2-Methyl-4-chlorophenoxy)butyric } \\
\text { acid) }\end{array}$ & 2 & 69 & 74 & 72 \\
\hline Metalaxyl & 2 & 101 & 103 & 102 \\
\hline Methiocarb & 2 & 83 & 105 & 94 \\
\hline Methomyl & 2 & 98 & 105 & 102 \\
\hline Metsulfuron methyl & 2 & 108 & 181 & 145 \\
\hline Neburon & 2 & 93 & 94 & 94 \\
\hline Nicosulfuron & 2 & 287 & 346 & 317 \\
\hline Norflurazon & 2 & 104 & 110 & 107 \\
\hline Oryzalin & 2 & 83 & 84 & 84 \\
\hline Oxamyl & 2 & 92 & 94 & 93 \\
\hline Picloram & 2 & 72 & 76 & 74 \\
\hline Propham & 2 & 61 & 91 & 76 \\
\hline Propiconazole & 2 & 84 & 87 & 86 \\
\hline Propoxur & 2 & 102 & 102 & 102 \\
\hline Siduron & 2 & 105 & 123 & 114 \\
\hline Sulfometuron-methyl ${ }^{1}$ & 2 & 126 & 145 & 136 \\
\hline Tebuthiuron $^{1}$ & 2 & 110 & 122 & 116 \\
\hline Terbacil & 2 & 78 & 87 & 83 \\
\hline Triclopyr & 2 & 84 & 92 & 88 \\
\hline
\end{tabular}

${ }^{1}$ Constituent detected in groundwater samples.

Table A5E. Quality-control summary for matrix-spike recoveries of the constiuent of special interest'1, 1,2,3-trichloropropane, in spiked samples collected for trends in seven Groundwater Ambient Monitoring and Assessment (GAMA) Priority Basin Project study units.

[Acceptable recovery range is between 70 and 130 percent]

\begin{tabular}{ccccc}
\hline Constituent & $\begin{array}{c}\text { Number of } \\
\text { spike samples }\end{array}$ & $\begin{array}{c}\text { Minimum recovery } \\
\text { (percent) }\end{array}$ & $\begin{array}{c}\text { Maximum recovery } \\
\text { (percent) }\end{array}$ & $\begin{array}{c}\text { Median recovery } \\
\text { (percent) }\end{array}$ \\
\hline $1,2,3$-Trichloropropane $(1,2,3-\mathrm{TCP})^{2}$ & 3 & 88 & 147 & 118 \\
\hline
\end{tabular}

${ }^{1}$ Matrix spikes were not collected for perchlorate or $N$-nitrosodimethylamine during re-sampling for trends.

${ }^{2}$ Constituent detected in groundwater samples. 

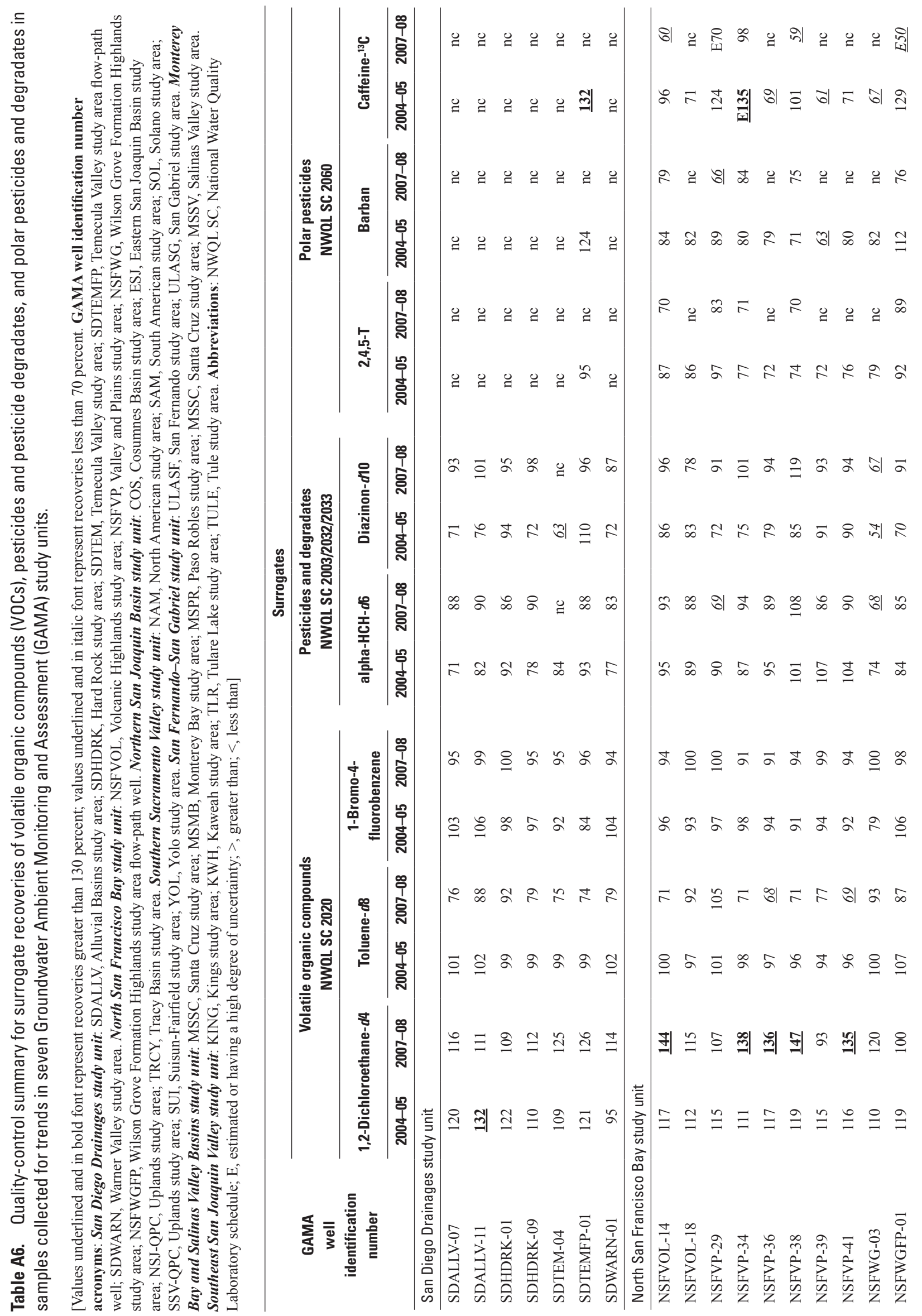

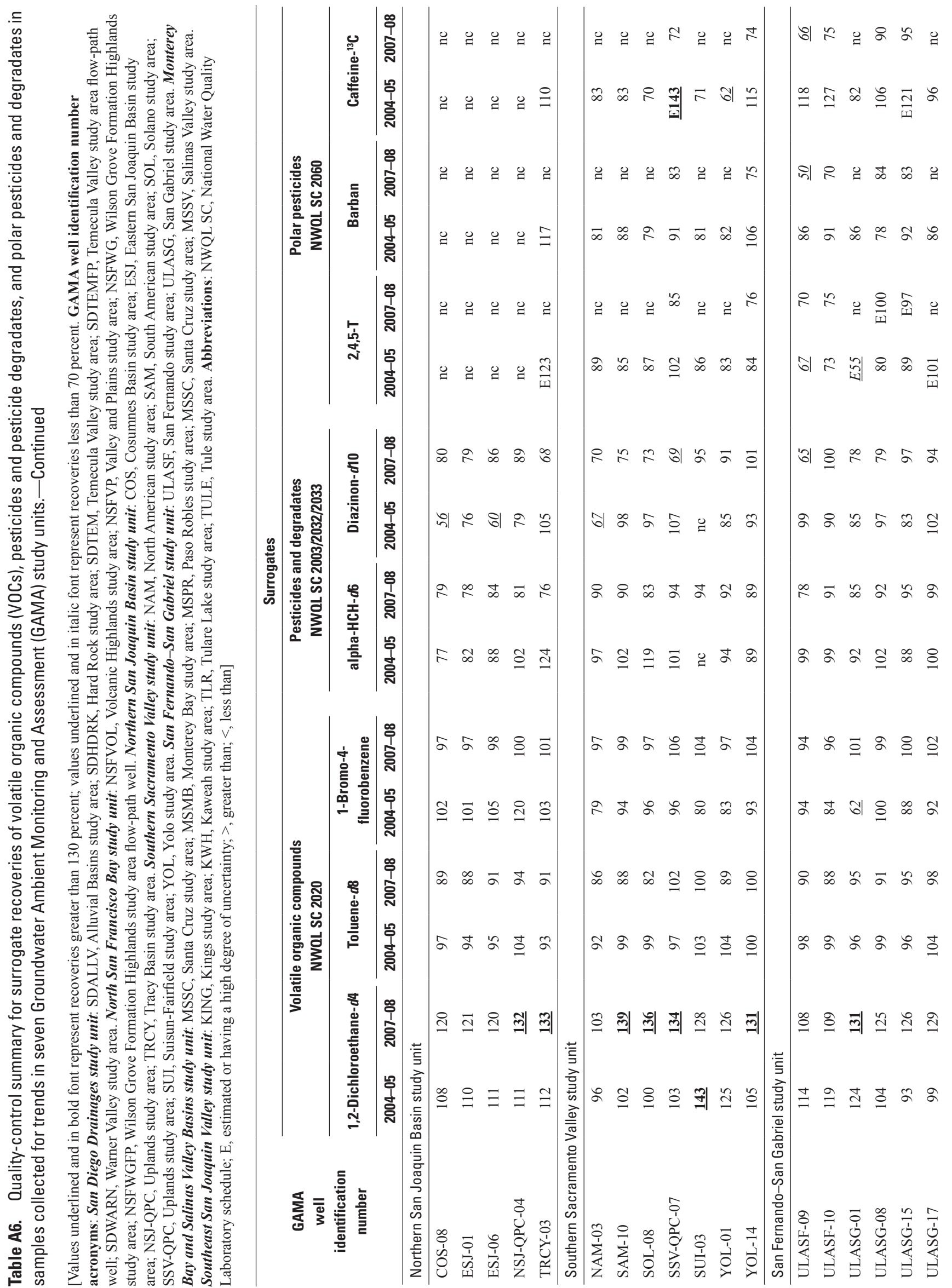

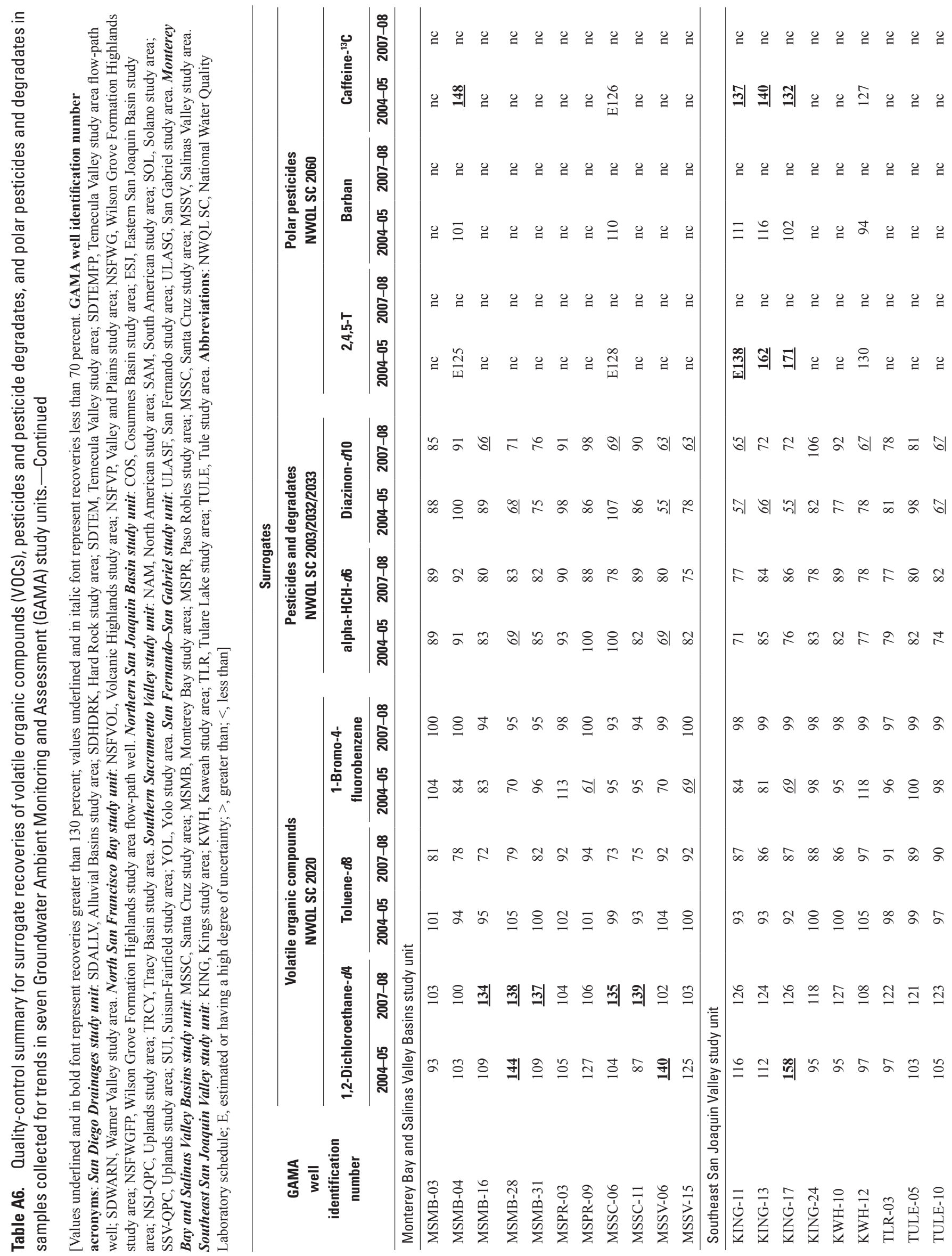


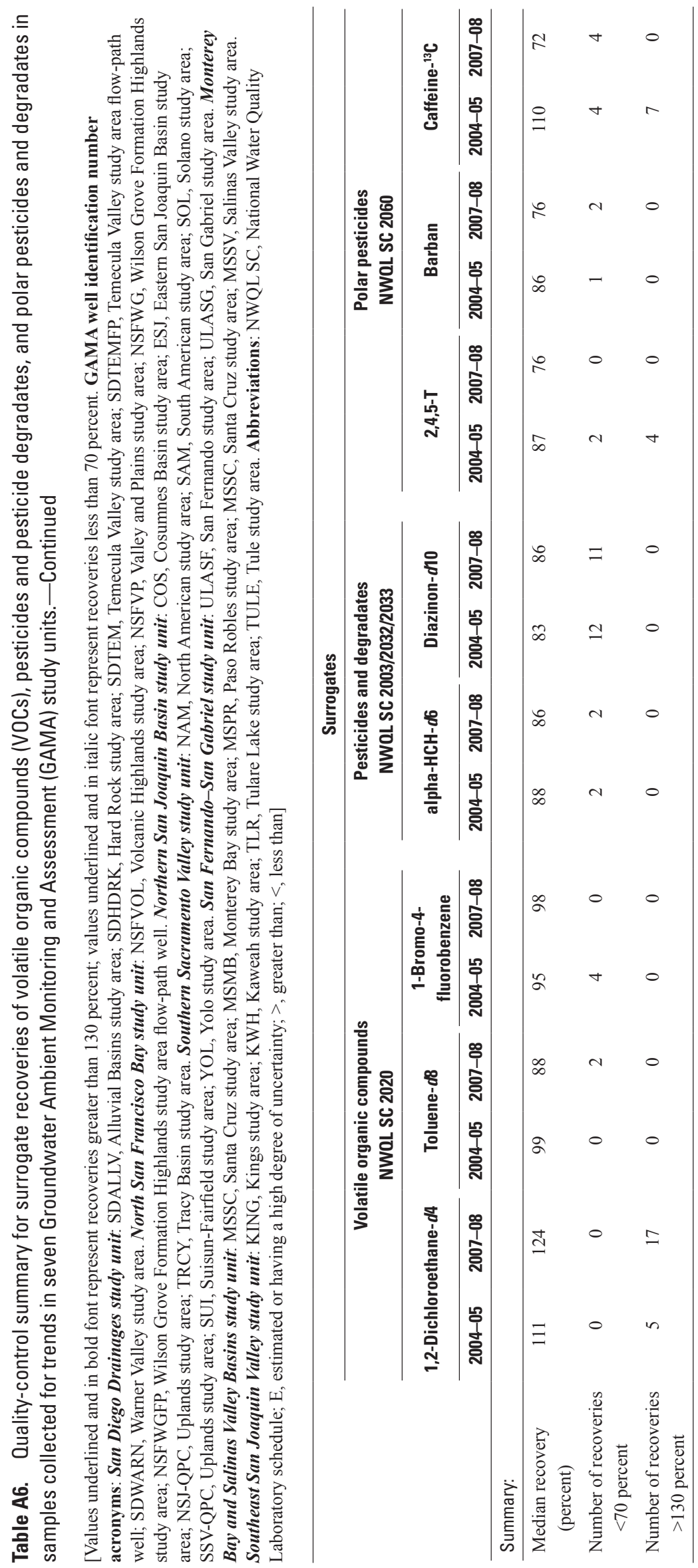


Publishing support provided by the U.S. Geological Survey Science

Publishing Network, Sacramento, Tacoma, and Raleigh Publishing Service Centers

For more information concerning the research in this report, contact the Director, California Water Science Center

U.S. Geological Survey 6000 J Street, Placer Hall

Sacramento, California 95819

http://ca.water.usgs.gov 



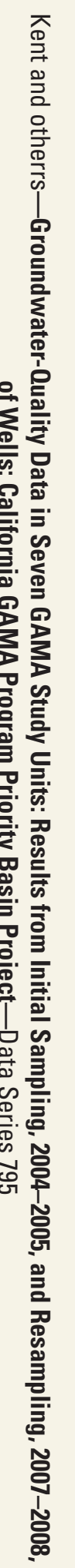

8 Printed on recycled paper 